UNIVERSIDADE DE SÃO PAULO

ESCOLA DE COMUNICAÇÕES E ARTES

PROGRAMA DE PÓS-GRADUAÇÃO EM MEIOS E PROCESSOS AUDIOVISUAIS

DANILO NAZARENO AZEVEDO BARAÚNA

MODOS DE ESPACIALIZAÇÃO DO VÍDEO NA ARTE CONTEMPORÂNEA

SÃO PAULO 
Autorizo a reprodução e divulgação total ou parcial deste trabalho, por qualquer meio convencional ou eletrônico, para fins de estudo e pesquisa, desde que citada a fonte.

Catalogação na Publicação Serviço de Biblioteca e Documentação

Escola de Comunicações e Artes da Universidade de São Paulo Dados fornecidos pelo(a) autor(a)

Baraúna, Danilo Nazareno Azevedo

Modos de espacialização do vídeo na arte contemporânea / Danilo Nazareno Azevedo Baraúna. -- São Paulo: D. N. A. Baraúna, 2016.

197 p.: il. + DVD.

Dissertação (Mestrado) - Programa de Pós-Graduação em Meios e Processos Audiovisuais - Escola de Comunicações e Artes / Universidade de São Paulo.

Orientador: Almir Antonio Rosa

Bibliografia

1. Vídeo 2. Espaço 3. Operações de espacialização 4. Modos de espacialização 5. Arte contemporânea I. Rosa, Almir Antonio II. Título. 
DANILO NAZARENO AZEVEDO BARAÚNA

MODOS DE ESPACIALIZAÇÃO DO VÍDEO NA ARTE CONTEMPORÂNEA

Dissertação apresentada ao Departamento de Cinema, Rádio e Televisão da Escola de Comunicações e Artes da Universidade de São Paulo para obtenção do título de Mestre em Ciências pelo Programa de Pós-graduação em Meios e Processos Audiovisuais.

Área de Concentração: Meios e Processos
Audiovisuais

Linha de Pesquisa: Poéticas e Técnicas

Orientador: Prof. Dr. Almir Antonio Rosa

\section{SÃO PAULO}


Nome: Danilo Nazareno Azevedo Baraúna

Título: Modos de espacialização do vídeo na arte contemporânea

Dissertação apresentada ao Departamento de Cinema, Rádio e Televisão da Escola de Comunicações e Artes da Universidade de São Paulo para obtenção do título de Mestre em Ciências pelo Programa de Pós-graduação em Meios e Processos Audiovisuais.

Área de Concentração: Meios e Processos Audiovisuais Linha de Pesquisa: Poéticas e Técnicas

Orientador: Prof. Dr. Almir Antonio Rosa

Aprovado em:

\section{Banca Examinadora}

Prof. Dr. Almir Antonio Rosa

Julgamento:

Profa. Dra. Patrícia Moran Fernandes

Julgamento:

Profa. Dra. Rosangela da Silva Leote

Julgamento:

\section{SUPLENTES:}

Profa. Dra. Agda Regina de Carvalho

Julgamento:

Prof. Dr.Cristian da Silva Borges

Julgamento:

Prof. Dr. Eduardo Simões dos Santos Mendes Julgamento:

Prof. Dr. Orlando Franco Maneschy

Julgamento:
Instituição: Universidade de São Paulo

Assinatura:

Instituição: Universidade de São Paulo

Assinatura:

Instituição: Universidade Estadual Paulista

"Júlio de Mesquita Filho"

Assinatura:

Instituição: Universidade Anhembi Morumbi

Assinatura:

Instituição: Universidade de São Paulo

Assinatura;

Instituição: Universidade de São Paulo

Assinatura:

Instituição: Universidade Federal do Pará

Assinatura: 


\section{AGRADECIMENTOS}

À Fundação de Amparo à Pesquisa do Estado de São Paulo (FAPESP), pelo financiamento deste trabalho por meio de Bolsa de Pesquisa no País - BP.MS (Processo no 2014/16163-9) e Bolsa de Estágio em Pesquisa no Exterior - BE.EP.MS (Processo no 2015/14150-0), e à Coordenação de Aperfeiçoamento de Pessoal de Nível Superior (CAPES) que financiou essa pesquisa nos cinco primeiros meses do curso de mestrado.

Ao meu pai Luis, minha mãe Marlise, meu irmão Rafael e minha irmã Fabíola por todo o empenho e amor durante toda a minha vida e percurso acadêmico, nenhuma conquista seria possível sem o apoio de vocês. Estendo o agradecimento à Rafaella Baraúna e Rômulo Souza, que já fazem parte da família. À minha tia Marluce por todo amor e atenção à minha família. Ao meu tio Paulo por proporcionar alguns os melhores momentos da minha infância e juventude. Aos amigos Haroldo França, Franco Salluzio, Helen Nascimento, Mayara Vale, Nigel Anderson, Raíssa Araújo, Rafael Reis e Rosiana da Paz, minha família em São Paulo. Aos amigos de Belém Anne Chagas e Pedro Machado, estarão sempre comigo mesmo que à distância. Aos amigos integrantes do conselho editorial da Revista Movimento, com quem compartilhei importantes aprendizados. Especial agradecimento ao Nigel Anderson e Pedro Machado pelos quase dez anos da mais sincera e amorosa amizade. À Marina Kerber pela amizade e parceria nesse percurso do mestrado em que dividimos sonhos, aprendizados e angústias. Ao Prof. Dr. Almir Almas, por ser essa figura inspiradora, pela orientação sempre séria e comprometida, por ter acreditado no potencial de desenvolvimento da minha pesquisa e me proporcionar o envolvimento em seus projetos, com os quais obtive aprendizados extremamente valiosos. À Profa. Dra. Rosangella Leote pelas contribuições a essa pesquisa, pela confiança no meu trabalho e oportunidade de parcerias, e por ser sempre uma inspiração para o meu percurso desde a graduação. Ao Prof. Dr. Timothy Barker pela supervisão e considerações decisivas para a realização de parte deste estudo durante o Estágio de Pesquisa no Exterior realizado na Universidade de Glasgow. À Profa. Dra. Patrícia Moran também pelas contribuições a essa pesquisa durante todo o percurso do mestrado. Ao Prof. Dr. Orlando Maneschy, pela amizade, confiança, inspiração e oportunidades concedidas que foram desde a graduação decisivas para minha formação, e com o qual hoje compartilho uma parceria de pesquisa que sempre me engrandece. À Profa. Dra. Cláudia Leão, pela amizade, torcida, aprendizados e por ter me apresentado os estudos de Vilém Flusser. A todos os integrantes do Grupo Internacional e Insterinsitucional de Pesquisa em Convergências entre Arte, Ciência e Tecnologia (IA/UNESP) pelas tão produtivas trocas e discussões, em especial à Hosana Celeste, amiga e parceira de escrita com a qual aprendi tanto. À Associação Cultural Videobrasil por ter aberto seu acervo para que essa pesquisa pudesse ser realizada, nas pessoas de Solange Farkas, diretora da associação, à Juliana Costa que me acompanhou tão cuidadosamente e pacientemente durante todo esse processo um agradecimento especial, o pesquisador Ruy Luduvice e Leonardo Zerino pela ajuda na captura dos frames dos vídeos que compõem esse trabalho. Ao Centre for Contemporary Arts de Glasgow por ter apoiado parte de minha pesquisa por meio da disponibilização de seu cinema para a realização da mostra Amazonian Video Art durante a BEPE-FAPESP. Por fim a todos os artistas que apoiaram essa pesquisa autorizando a utilização das imagens de seus trabalhos e doando materiais. 
O espaço é cheio de buracos: nós, as coisas, os mundos. A perfeição seria o espaço puro, fica ele a pensar com os seus buracos ... Mas isso, Sr. Espaço, é uma coisa tão impossível como a poesia pura. 


\section{RESUMO}

BARAÚNA, D.N.A. Modos de espacialização do vídeo na arte contemporânea. 2016. 197 f. Dissertação (Mestrado) - Departamento de Cinema, Rádio e Televisão, Escola de Comunicações e Artes, Universidade de São Paulo, São Paulo, 2016.

Neste trabalho analisaremos as operações utilizadas por artistas para estabelecer relações entre a videoarte e o seu espaço físico de instauração a partir do estudo de amostragens estratificadas de obras realizadas entre os anos de 1990 e 2015 pertencentes aos acervos do Festival de Arte Contemporânea Sesc_Videobrasil da Associação Cultural Videobrasil, do projeto de pesquisa "Acervo de Videoarte paraense: sistematização e análise crítica" (CNPq/SEC/MinC) e de obras coletadas em nosso Estágio de Pesquisa no Exterior (BEPE-FAPESP). Utilizamos um método de abordagem hipotético-dedutivo e método de procedimento de caráter tipológico. No primeiro capítulo levantaremos algumas caraterísticas do elemento espaço físico e os mecanismos de representação deste em imagens bidimensionais. No segundo capítulo discutimos as características do vídeo no par convergência/especificidade com relação a certas práticas e movimentos da televisão, cinema e computador, apontando para problematizações sobre a videoarte no espaço da galeria. No terceiro capítulo indicamos a análise de duas possíveis situações de espacialização do vídeo, às quais estão diretamente relacionados ao tamanho físico da imagem exposta no espaço. À primeira operação denominamos micro-espacialização e está relacionada ao vídeo em pequenas dimensões com relação ao espaço e ao público, constituída por modos de espacialização diferenciados, a saber: 1) Vídeo-espaço; 2) Aparelho-espaço; 3) Vídeodistensão. Classificou-se como macro-espacializações a segunda operação, ligada à exibição do vídeo em grandes proporções em relação ao espaço e ao corpo do espectador a partir de projeções ou multiplicação de monitores, formada por modos de espacialização denominados de: 1) Situação-cinema; 2) Vídeo-cenário; 3) Vídeo-dilatação. Para efeito de análise utilizamos os estudos de alguns autores como: Arlindo Machado (1997 e 1988), Brian O'Doherty (1999), Chris Meigh-Andrews (2014), Claire Bischop (2005), Erika Balsom (2013), Henri Bergson (2012), Lev Manovich (2001), Maurice Merleau-Ponty (2014 e 2011), Michael Rush (2014 e 2006), Noel Burch (2011), Phillipe Dubois (2004), e Timothy Barker (2012).

Palavras-chave: Vídeoarte. Operações de espacialização. Modos de Espacialização. 


\begin{abstract}
BARAÚNA, D.N.A. Modes of spatialization of video in contemporary art. 2016. 197 p. Dissertation (Master Degree) - Department of Cinema, Radio and Television, School of Communications and Arts, University of São Paulo, São Paulo, 2016.

In this work we aim to analyse the operations used by artists to establish relationships between video art and its physical space of instauration from the study of stratified samples of works of art produced betwen the years of 1990 and 2015 in the collections of Contemporary Art Festival Sesc_Videobrasil of Cultural Association Videobrasil, from research project "Collection of Video art from Pará: sistematization and critical analysis" (CNPq/SEC/MinC) and the works of art collected during our Research Internship Abroad. We used a hipothetical-deductive approach and a tipological method of procedure. In the first chapter we will rise some characteristics of the physical space and the mechanisms of its representation in bidimensional images. In the second chapter we discuss the video characteristics from the convergences/specificities related to some practices and movements on television, cinema and computer, showing the problematization of videoart in the space of gallery. In the third chapter we indicate the analysis of two possible video's spacialization, related to the physical size of the image exhibted. We called the first operation micro-spacialization, related to video in small size in its relationships with the space and public body's, constituted by the following modes of spacialization: 1)Video-space; 2) Device-space; 3) Video-distension. The second operation Macro-spacialization, is related to video exhibition in large scales from video projections and the multiplication of monitors, formed by these modes of spacialization: 1) Cinema-situation; 2) Video-scenario; 3) Video-dilatation. To the analysis of these situations we used the studies of some authors, including: Arlindo Machado (1997 and 1988), Brian O'Doherty (1999), Chris Meigh-Andrews (2014), Claire Bischop (2005), Erika Balsom (2013), Henri Bergson (2012), Lev Manovich (2001), Maurice Merleau-Ponty (2014 and 2011), Michael Rush (2014 and 2006), Noel Burch (2011), Phillipe Dubois (2004), and Timothy Barker (2012).
\end{abstract}

Keywords: Vídeo Art. Modes of spacialization. Operations of spacialization. 


\section{LISTA DE ILUSTRAÇÕES}

Ilustração 01: Instalação de Robert Morris (1964) na Green Gallery em Nova York (EUA) ................ 44

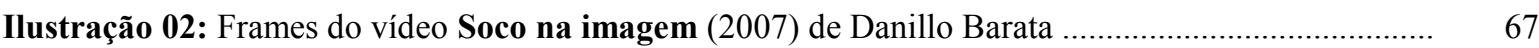

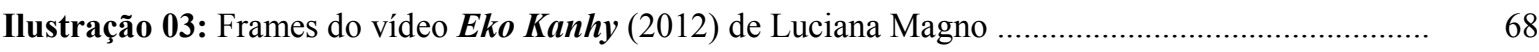

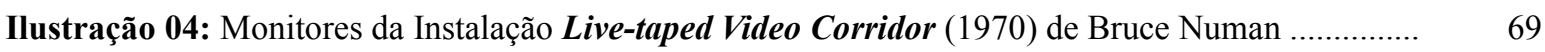

Ilustração 05: Vista geral da instalação Live-taped Video Corridor (1970) de Bruce Nauman ............. 70

Ilustração 06: Registro da obra Nixon (1965-2002) de Nam June Paik ................................................. 74

Ilustração 07: Frames da versão em vídeo online do filme Berlin Horse (1970) de Malcolm Le Grice 80

Ilustração 08: Frames da versão em vídeo online do filme Threshold (1972) de Malcolm Le Grice ..... 81

Ilustração 09: Frames do vídeo City Tour (2008) de Dirceu Maués......................................................... 83

Ilustração 10: Frames do vídeo Vermelho (2007) de Melissa Barbery .............................................. 85

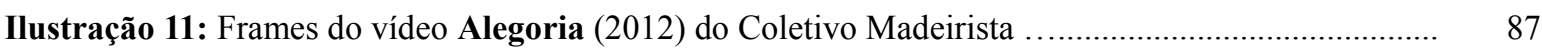

Ilustração 12: Frames do vídeo Estudo sobre a escuridão (2009) de Márcia Vaitsman ...................... 89

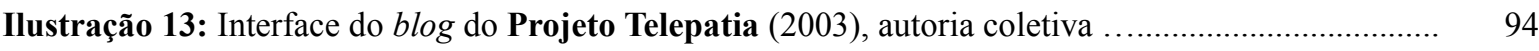

Ilustração 14: Primeira tela da obra em CD-ROM Bodyweave (2005) de Lali Krotoszynski ............... 96

Ilustração 15: Segunda tela da obra em CD-ROM Bodyweave (2005) de Lali Krotoszynski ................ 97

Ilustração 16: Terceira tela da obra em CD-ROM Bodyweave (2005) de Lali Krotoszynski ............... 98

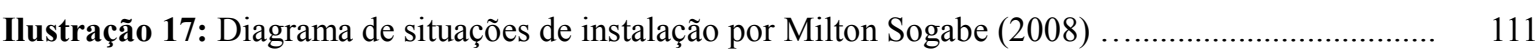

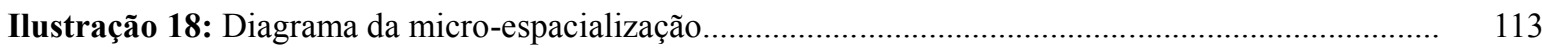

Ilustração 19: Frames do vídeo Getting Out (1983) de Rafael França ................................................. 116

Ilustração 20: Frames do vídeo Barrueco (2004) de Ayrson Heráclito e Danillo Barata ......................... 118

Ilustração 21: Frames do vídeo Fast / Slow_Scapes (2006) de Gisele Beiguelman ............................. 122

Ilustração 22: Frames do vídeo Radicais Livre/os (2006) de Marcus Bastos ........................................... 122

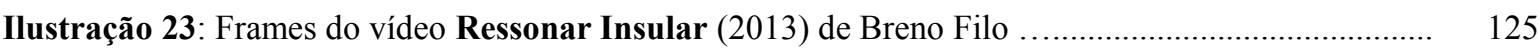

Ilustração 24: Registro de O Senhor é meu pastor e nada me faltará (2012) de Victor De La Rocque 128

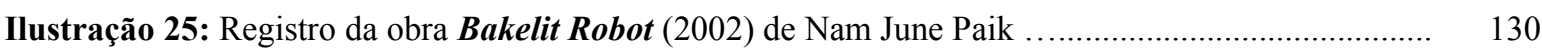

Ilustração 26: Registro da obra O JOGO ou para que servem os amigos? (2006) de Valzeli Sampaio 133

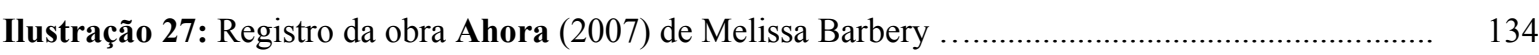

Ilustração 28: Frames do vídeo que compõe a obra Ahora (2007) de Melissa Barbery ......................... 135

Ilustração 29: Registro da obra Victrola (2005) de Nam June Paik .................................................. 137

Ilustração 30: Registro da obra Pandora The Electronic Box (1993) de Mariano Klautau Filho ......... 138

Ilustração 31: Registro da obra Pandora The Electronic Box (1995) de Mariano Klautau Filho ......... 140

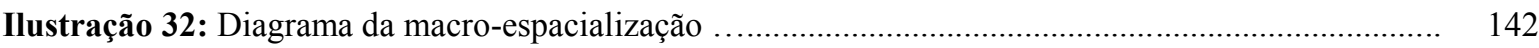

Ilustração 33: Registro da obra Cidades Vulneráveis (2008) de Carla Evanovitch ................................ 145

Ilustração 34: Frames do vídeo Cidades Vulneráveis (2008) de Carla Evanovitch ............................. 147

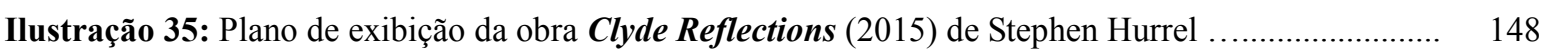

Ilustração 36: Frames do vídeo Clyde Reflections (2015) de Stephen Hurrel .................................. 149 
Ilustração 37: Registro da obra Buruburu (2011) de Ayrson Heráclito

Ilustração 38: Registro da obra Santoscópio - Dumontagem (2011) de Carlos Adriano ..................... 152

Ilustração 39: Registro da obra Santoscópio - Dumontagem (2011) de Carlos Adriano ..................... 152

Ilustração 40: Frames do vídeo da obra Santoscópio - Dumontagem (2011) de Carlos Adriano .......... 153

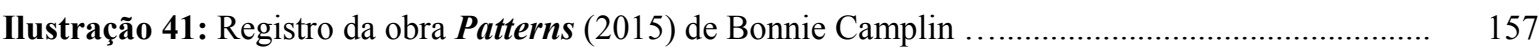

Ilustração 42: Registro da obra Patterns (2015) de Bonnie Camplin ............................................ 157

Ilustração 43: Registro da obra Crossing Points (2011) de Edwin Sanchez ..................................... 159

Ilustração 44: Registro da obra Performações urbanas (2009) de Carla Evanovitch ............................ 161

Ilustração 45: Registro da obra Performações urbanas (2009) de Carla Evanovitch ........................ 162

Ilustração 46: Registro da obra Permanência (2007) de Valzeli Sampaio e Mariano Klautau Filho ...... 167

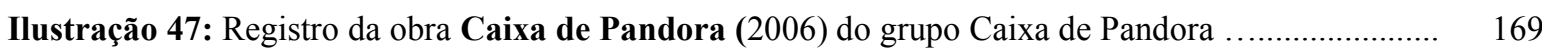

Ilustração 48: Interface do blog da obra Mangueiras de Belém (2011) de Valzeli Sampaio ................ 170

Ilustração 49: Registro da obra Mangueiras de Belém (2011) de Valzeli Sampaio .............................. 171

Ilustração 50: Registro da obra Beneath and Beyond (2008) de Stephen Hurrel .............................. 172

Ilustração 51: Registro da performance audiovisual Corpo 4K (2014) de Almir Almas ..................... 175

Ilustração 52: Registro da performance audiovisual Corpo 4K (2014) de Almir Almas ...................... 176 


\section{LISTA DE TABELAS}

Tabela 01: Formatos de gravação, armazenamento e transmissão de vídeo 58 


\section{SUMÁRIO}

Introdução

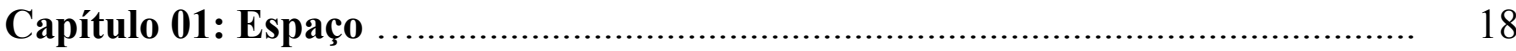

1.1. Espaço e representação.................................................................................... 40

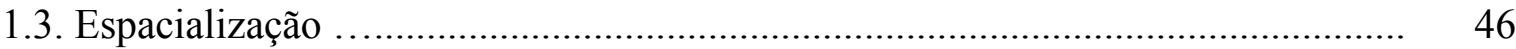

Capítulo 02: Vídeo ….................................................................................. 50

2.1. Linguagens e imagens em contaminação: a videoarte ...................................... 57

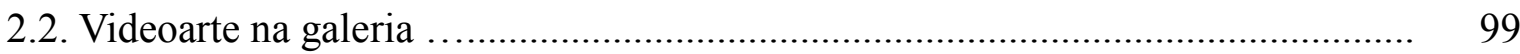

Capítulo 03: Modos de espacialização do vídeo …................................................ 107

3.1. Primeira operação: micro-espacializações ......................................................... 113

3.1.1. Primeiro modo: Vídeo-espaço ................................................................... 112

3.1.2. Segundo modo: Aparelho-espaço .............................................................. 127

3.1.3. Terceiro modo: Vídeo-distensão ............................................................... 131

3.2. Segunda operação: macro-espacializações ........................................................ 141

3.2.1. Primeiro modo: Situação-cinema .................................................................. 143

3.2.2. Segundo modo: Vídeo-cenário ................................................................... 155

3.2.3. Terceiro modo: Vídeo-dilatação ..................................................................... 163

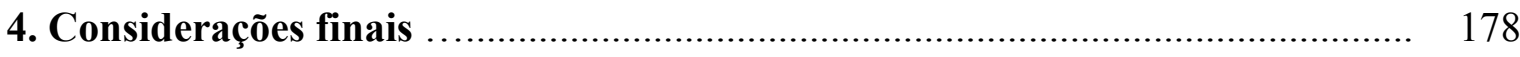

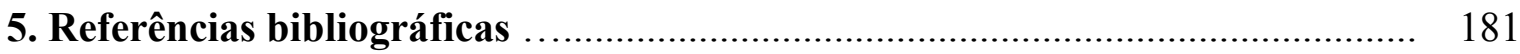

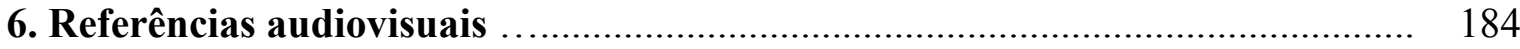

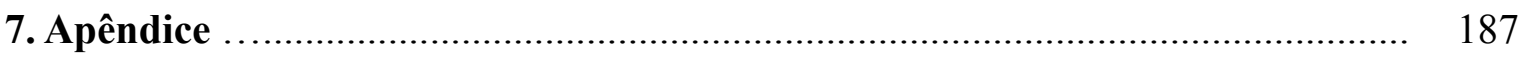

7.1. Apêndice A - Dados de obras citadas ............................................................ 188 


\section{INTRODUÇÃO}

Um número considerável de autores já se debruçou sobre a problemática que envolve a concepção do vídeo e seu lugar na história dos meios contemporâneos, incluindo o processo de expansão da linguagem videográfica na arte contemporânea, o que de maneira geral denominou-se como videoarte. Seguindo esse caminho a questão principal que se coloca nesse trabalho é a da análise das relações entre a videoarte e as abordagens espaciais que a atravessam em obras produzidas a partir da década de 1990, culminando em práticas instalativas em que o contexto de exibição e seus arranjos possíveis na relação com outros elementos se torna fundamental. Perguntamo-nos então: quais são esses arranjos compositivos que artistas tem utilizado para possibilitar a expansão do pensamento do dispositivo vídeo para além da imagem eletrônica/digital bidimensional? De modo geral, nosso esforço é o de demonstrar como certas práticas de organização espacial do vídeo são recorrentes em trabalhos de vários artistas nesse campo que chamamos de arte contemporânea.

Para essa pesquisa baseamos nossos procedimentos metodológicos nas proposições de Eva Maria Lakatos e Marina de Andrade Marconi realizadas na publicação Fundamentos de Metodologia Científica (2010). A pesquisa se configura por uma abordagem hipotéticodedutiva, na medida em que partimos de um problema que surge da observação de pesquisas anteriores, e que desembocaram nos questionamentos levantados acima. Esses estudos citados se tratam de nossas pesquisas de iniciação científica ${ }^{1}$ realizadas durante a graduação e que se referiam especificamente à produção imagética da cidade de Belém, no estado do Pará, ocasião em que chegamos a identificar algumas recorrências compositivas no que se refere a prática da videoarte e levantamos a problematização do espaço como fundante de sua natureza, conforme apontado por alguns autores que havíamos estudado e que retomamos nesse trabalho. A questão que se colocou foi se essas recorrências poderiam ser ampliadas para além da discussão de uma produção geograficamente localizada, o que nos motivou a ir ao encontro de outros artistas e acervos que pudessem nos auxiliar nessa abordagem de um campo mais amplo que não apenas o da produção paraense. A identificação dessas recorrências confere ao estudo um método de procedimento de caráter tipológico, na medida em que procuramos definir grupos de análise a

1 Pesquisas realizadas na Faculdade de Artes Visuais do Instituto de Ciências da Arte da Universidade Federal do Pará por meio do Programa Institucional de Bolsa de Iniciação Científica (PIBIC). Planos de trabalho intitulados Instaurações: imagem e suas relações com o espaço na arte contemporânea de Belém (20092010) e Especificidades de lugar: instaurações na cena belenense (2010-2011), financiados respectivamente pelo Conselho Nacional de Desenvolvimento Científico e Tecnológico (CNPq) e pela

Fundação Amazônia Paraense de Amparo à Pesquisa (FAPESPA). 
partir do estudo de diversos casos buscando características comuns entre eles.

A partir da observação de obras nesses estudos anteriores lançamos a hipótese de que essas produções contemporâneas apresentam duas operações de espacialização básicas ao se relacionarem com o espaço de instauração e que se materializaram em dois eixos de análise amplos. O primeiro eixo denominamos micro-espacializações (imagens em pequenas dimensões e sua extensão na agregação de objetos no espaço) e o segundo macroespacializações (construção de ambientes em grandes dimensões em que a imagem do vídeo é integrante). As operações se articulam em modos de espacialização, esses últimos entendidos como camadas de formação das operações de espacialização, a partir de determinadas relações existentes entre objetos tridimensionais instalados no espaço físico e a presença / ausência do corpo do artista e do corpo do público, dialogando com Jacques Aumont (1993) ao atentar para a diferença relacional que se estabelece com uma imagem de acordo com sua dimensão física. Essas questões elencadas surgiram, portanto, como parâmetro primeiro para a análise dos trabalhos que nos deparamos nessa pesquisa e que serão apresentados ao longo do texto. Embora tenhamos mantido esses eixos de análise, eles foram se transformando enquanto conceito à medida em que entramos em contato com uma diversidade de trabalhos que acrescentavam camadas não previstas em nossa abordagem inicial, o que abre a possibilidade de desdobramentos em outros modos de espacialização não indicados no decorrer desse trabalho ou mesmo a derrubada destes em pesquisas futuras, conforme indicaremos em nossas considerações finais.

Dito isso, o nosso esforço pela busca de outros objetos de estudo se funda na questão já mencionada sobre a existência dessas recorrências em uma variedade de práticas que não tem necessariamente relação com uma questão local. Essa ampliação dos materiais de análise se configura a partir de três instâncias: 1) acervo do projeto de pesquisa Acervo de videoarte paraense: sistematização e análise crítica $\left.{ }^{2} ; 2\right)$ acervo do Festival de Arte Contemporânea SESC_Videobrasil da Associação Cultural Videobrasil ${ }^{3}$; 3) Trabalhos coletados durante nosso Estágio de Pesquisa no Exterior (BEPE).

2 Projeto de pesquisa contemplado em 2014 no Edital de Economia Criativa, uma parceria entre o Conselho Nacional de Desenvolvimento Científico e Tecnológico e a extinta Secretaria de Economia Criativa do Ministério da Cultura do Brasil. Resultou no livro PARÁ + VíDEO + ARTE: notas introdutórias a uma historiografia da videoarte no Pará, a ser publicado esse ano pela Editora do Programa de Pós-Graduação em Artes da Universidade Federal do Pará, com organização deste autor e de Orlando Maneschy.

3 Sediada em São Paulo e fundada em 1984 por Solange Farkas constituiu ao longo dos seus mais de 30 anos um vasto acervo de video e foi diretamente responsável pelo fomento à produção nacional, principalmente a partir do hoje denominado Festival de Arte Contemporâne Sesc_Videobrasil. Esse acervo é constantemente ativado por meio de ações de pesquisa e realização de exposições com os trabalhos que o compõe. Têm dado atenção especial à discussão da produção do sul geopolítico do mundo, no diálogo com artistas da América Latina, África, Leste Europeu, Ásia e Oriente Médio. Fonte: www.videobrasil.org.br 
O primeiro acervo é um desdobramento de nossas pesquisas de iniciação científica já citadas anteriormente e conta com um total de duzentos e vinte e um trabalhos em vídeo monocanal ou em formato instalativo produzidos entre os anos de 1989 e 2015 no estado do Pará. Para esta pesquisa de mestrado propusemos a expansão desse estudo para um âmbito nacional, de modo a dialogar com produções brasileiras a partir de outro importante acervo, o do Festival de Arte Contemporânea Sesc_Videobrasil da Associação Cultural Videobrasil, sediada na cidade de São Paulo e um dos principais responsáveis pela instauração e amadurecimento da produção videográfica de caráter experimental no Brasil. Para esse acervo estabelecemos como parâmetro as produções exibidas entre 1992 e 2013, perfazendo um total de dez edições com nomenclaturas diversas ao longo dos anos. A escolha pelo Festival de Arte Contemporânea Sesc_Videobrasil deve-se ao fato de que ao longo dos seus 30 anos de existência a curadoria do evento chegou à compreensão desse processo de expansão do vídeo na sua relação com outros elementos como objetos, o corpo participador, o espaço e englobou uma série de tipologias de linguagens artísticas. Esse recorte a partir da edição de 1992 foi determinado em primeira instância para fins de diálogo entre os períodos históricos desses dois acervos citados.

Ainda durante nosso percurso no mestrado tivemos a possibilidade de realizar um estágio de pesquisa no exterior na Universidade de Glasgow (Escócia) ${ }^{4}$, que configurou por fim o nosso terceiro mecanismo de levantamento de obras e coleta de materiais. Nessa pesquisa entramos em contato com artistas participantes do conjunto de exposições denominado GENERATION: 25 years of Contemporary Art in Scotland, tais como Stephen Hurrel, Simth/Stewart, Shonna Macnaughton e Graham Fagen. Esse conjunto de exposições foi selecionado por abarcar os mais representativos artistas que trabalham com a videoarte e instalações na Escócia, incluindo residentes na cidade de Glasgow e, além disso, cobriu um recorte histórico muito similar ao dos acervos que vimos estudando no Brasil, com obras produzidas entre os anos de 1989 e 2014.

Essa exposição aconteceu no ano de 2014 em várias cidades da Escócia como Glasgow, Edimburgo, Dundee, Inverness, entre outras, e de acordo com a curadoria foi um dos mais ambiciosos projetos de discussão de uma produção nacional já realizado até hoje. Além disso pudemos coletar materiais em exposições às quais visitamos em nosso período de pesquisa, como a individual de recentes trabalhos de Nam June Paik na Tate Modern em Londres e a

4 Estágio realizado na School of Culture and Creative Arts da Universidade de Glasgow (Glasgow, Escócia), com orientação do Dr. Timothy Scott Barker e financiamento da Bolsa de Pesquisa em Estágio no Exterior (BEPE) da Fundação de Amparo à Pesquisa do Estado de São Paulo (BEPE). 
mostra do Turner Prize 2015 na Tramway Gallery em Glasgow, as quais compõem também nosso trabalho.

Importante frisar que o texto dessa dissertação não se valeu de todos os trabalhos pertencentes aos citados acervos, mas sim de amostragens estratificadas, segundo nomenclatura de Antônio Carlos Gil (2009), que serviram de índice para a implantação de discussões relacionadas a um contexto maior de produções artística. Outro importante ponto é que essa delimitação histórica das obras não foi determinada aleatoriamente. $\mathrm{O}$ que percebemos, em diálogo com autores como Erika Balsom (2013), Timothy Barker (2012), Arlindo Machado (2007) e Liz Kotz (2009) foi que da década de 1990 em diante a videoarte passou a apresentarse por modos em que as características das práticas de anos anteriores aparecem sobrepostas e reconfiguradas pelo fortalecimento da relação com a linguagem digital. De maneira geral, longe de terem sumido e se tornarem historicamente localizadas, as ações de videoperformance dos primeiros videoartistas, o uso de sintetizadores, a problematização do aparelho de transmissão do vídeo e as questões do tempo presente, entre outras, se integram às novas propostas a partir da década de 1990 no diálogo com o computador, a projeção digital e propostas de interatividade e modificação em tempo real da narrativa videográfica, o que nos permite a compreensão do estado atual do vídeo como uma situação de retomada e rearticulação constante de sua própria história em outros contextos.

Para a seleção dos trabalhos artísticos que compõem esse texto realizamos uma etapa de pesquisa documental nos catálogos dessas exposições ou dossiês de obras na busca por identificar, a partir da sinopse e dados técnicos, trabalhos que estivessem atrelados às nomenclaturas do objeto, performance e instalação, já que estas categorias compõem teoricamente as variáveis que nos serviram de base para os agrupamentos conceituais que exploramos. Para fins de análise de cada uma dessas unidades-caso (trabalhos artísticos) selecionadas nos valemos dos seguintes critérios de caráter quantitativo e qualitativo: 1) tempo de exposição; 2) as características físicas e materiais da obra; 3) descrição dos componentes e dispositivos em geral; 4) as relações entre os elementos compositivos do vídeo e o espaço físico 5) as possíveis condutas, atitudes e comportamentos suscitados ao espectador em sua experiência com a obra e 6) o caráter presencial do artista no espaço físico (geralmente em performances). Partindo desses critérios pudemos então realizar um trabalho de agrupamento conceitual entre as obras e inclusão dessas em um dos eixos de análise que elencamos anteriormente, as operações e modos de espacialização do vídeo. Para cada um dos eixos de

5 Um dos principais prêmios de arte no Reino Unido, conferido a artistas com menos de cinquenta anos. 
análise que instituímos encontramos um número de pelo menos dez a vinte trabalhos que poderiam exemplificá-los e desses selecionamos alguns para apresentar nesse texto. Apesar do esforço de contato com todos os artistas selecionados nessa etapa não obtivemos algumas respostas, o que justifica a ausência de certas imagens dos trabalhos citados por questões de autorização legal.

Essas propostas que lidam com questões de arranjos espaciais têm um caráter potencialmente efêmero, haja vista que se pensarmos em museus e galerias enquanto espaço expositivo elas são montadas e desmontadas, dificultando o acesso direto às obras para pesquisas e para o público. O que "restam" dessas proposições são geralmente os registros em fotografia e vídeo, dossiês, textos. Além disso, podem envolver dispositivos de tempo, elementos olfativos, sonoros, táteis que não podem ser apanhados através de uma documentação restrita às imagens fixas. Por isso a importância de uma descrição desses trabalhos durante o texto, para assim estabelecer ligações entre os fragmentos das obras fixados nas imagens, bem como reconstruir o que poderia ter sido a totalidade de uma experiência efetiva junto a estas. Esperamos com esse trabalho também apresentar uma sistematização das relações espaciais do vídeo que, embora já explicitadas e analisadas por importantes autores como Phillippe Dubois (2004), Jacques Aumont (2005 e 1993), Arlindo Machado (1997 e 1988), Christine Mello (2008), Michael Rush (2014 e 2006) entre outros, encontram-se dispersas em publicações diversas e carecem de um tratamento analítico unificador.

Ao finalizarmos esse levantamento de obras uma outra questão então se impôs: do que se tratam esses dois elementos que viemos falando desde o início dessa introdução, o vídeo e o espaço? Antes de analisarmos os trabalhos pelo viés dessas operações e modos de espacialização foi, portanto, fundamental em nosso percurso de estudo levantar abordagens realizadas por alguns teóricos que dedicaram uma atenção a esses elementos, o que gerou os dois primeiros capítulos de nossa dissertação.

No primeiro capítulo, intitulado Espaço, estabelecemos um diálogo entre Maurice Merleau-Ponty (2014 e 2011) e Henri Bergson (2010) para encontrarmos uma possível definição ou se não pelo menos elucidar características dessa categoria por meio de um viés filosófico. Perceberemos como os autores se diferem em alguns pontos mas concordam que a busca por uma abordagem espacial deve ser atravessada pelo entendimento da experiência no espaço. Em um segundo momento nos ateremos à apresentação de questões sobre a representação do espaço tridimensional na imagem bidimensional, principalmente por meio dos estudos de Jacques Aumont (2005 e 1993) e Nöel Burch (2014), que nos indicam alguns mecanismos de construção e deformação desse aspecto na imagem. Em seguida retomamos ao 
espaço físico apresentado por Merleau-Ponty e Bergson para discutir um espaço arquitetônico específico, a galeria de arte e as manifestações que ali problematizaram questões espaciais como a instalação, a partir de autores como Claire Bishop (2005), Brian O'Doherty (1999) e Yi-Fu Tuan (2001). O capítulo é finalizado com a definição disso que chamamos espacialização, nomenclatura que percorrerá todo o nosso trabalho.

No segundo capítulo nos preocuparemos em indicar do que se trata esse segundo elemento de relação, o vídeo. Iniciamos o texto apresentando uma problematização acerca das questões teóricas da convergência/especificidade dessa mídia por meio de autores como Arlindo Machado (1997 e 2014), Erika Balsom (2013), Raymond Bellour (1997), Phillipe Dubois (2004) e Sean Cubitt (1993). Na segunda seção deste capítulo continuamos a discussão do tópico anterior apresentando algumas obras que materializam a construção de uma linguagem da vídeoarte a partir da relação com certos mecanismos e características da televisão, cinema e a influência da linguagem digital em suas novas configurações, principalmente a partir das contribuições teóricas de Chris Meigh-Andrews (2014), A.L. Rees (2011) e Lev Manovich (2001). O último tópico se refere a busca por uma especificidade da experiência com a videoarte que a diferiria da relação com o cinema e a televisão, apontando para questão dos discursos de interação que essas obras ativam, que seriam pressupostas pelas espacializações, e a existência de um certo mito da atividade nos espaços da galeria de arte.

No terceiro e último capítulo, após a definição do que compreendemos por vídeo e espaço, apresentaremos finalmente a partir das obras levantadas essas operações e modos de espacialização do qual falamos no início deste texto, conforme descritos a seguir. A primeira possível operação de espacialização refere-se ao desdobramento de imagens de pequenas dimensões, em que o público ainda se encontra em estado de superioridade no que se refere ao tamanho físico da imagem, o que se propõe chamar de Micro-espacializações. Esta operação seria formada por três modos de espacialização: 1) Vídeo-espaço: vislumbra a discussão dos arranjos internos ao quadro do vídeo como problematização espacial.; 2) Aparelho-espaço; preconiza o momento em que o artista se apodera do aparelho emissor da mensagem em vídeo e lhe atribui significados poéticos em formato escultural; 3) Vídeo-distensão: em que o vídeo e o aparelho de transmissão passam agora a estabelecer relações com objetos também de pequenas proporções que são instalados ao lado ou ao redor do monitor.

À segunda operação de espacialização propõe-se denominar Macro-espacializações, por estar integrada a ambientes em que a imagem domina o corpo do espectador, seja pela projeção ou pela multiplicação dessa e de monitores. Assim, outros três Modos de espacialização são propostos, a saber: 1) Situação-cinema: refere-se a propostas em que o 
espaço se restringe à utilização de grandes projeções, em uma ou mais telas, em ambientes onde o público se vê dominado fisicamente por essa imagem; 2) Vídeo-cenário, trabalhos em que o vídeo, projetado e/ou multiplicado em monitores, estabelece relações com os mais diversos objetos tridimensionais fundando um ambiente que dever ser percorrido geralmente em uma sala inteira; 3) Vídeo-dilatação: trabalhos ambientais com utilização da imagem em grandes dimensões e em que certas informações desse espaço são modificadas ao longo de sua exibição, em nível técnico e/ou simbólico, por algum agente que pode ser o artista, o público ou alguma ferramenta tecnológica de forma autônoma. Essas modificações podem acontecer no nível do próprio vídeo ou dos outros objetos que constituem esse ambiente, que também influenciarão a fruição desse vídeo. Para efeito de definição dos termos, é importante frisar que esta pesquisa se restringe ao estudo das relações do vídeo com espaços físicos fechados, dos quais poderíamos incluir galerias, museus e espaços culturais. No apêndice dessa dissertação disponibilizamos uma breve catalogação dos trabalhos citados ao longo do texto organizados por ordem alfabética dos títulos e com informações como ano, duração e sinopse, e que foram coletadas no site da Associação Cultural Videobrasil, enviadas pelos próprios artistas ou retiradas de placas de identificação de obras em exposição.

Esperamos com esse trabalho possibilitar uma compreensão, mesmo que parcial, desse universo da videoarte e suas relações com o espaço de exibição. Para isso, apontamos essas questões espaciais como um atravessamento fundamental na delimitação das convergências/especificidades dessa mídia no diálogo com outras instâncias de materialidades, compondo esse processo que chamamos espacialização. 
CAPÍTULO 01

ESPAÇO 
Se a matéria, enquanto extensão no espaço, deve ser definida, em nossa opinião, como um presente que não cessa de recomeçar, nosso presente, inversamente, é a própria materialidade de nossa existência, ou seja, um conjunto de sensações e de movimentos, nada mais. (BERGSON, 2010, p. 162).

Iniciamos este estudo trazendo à tona o pensamento do filósofo Henri Bergson (2010) para levantarmos questões referentes ao espaço como fenômeno perceptível. No entanto, não buscaremos aqui focar nos estudos de percepção, já que se trata de um universo complexo de significações pelo qual, no entanto, a concepção de espaço se entrelaça. Queremos aqui pontuar que o nosso esforço é o de buscar, em alguns importantes autores na Filosofia e na Teoria da Arte certos elementos que constituem uma possível definição de espaço.

Embora obviamente um fenômeno apreendido por meio da percepção, o espaço guarda características e elementos que foram ao longo do tempo reconhecidos como constituintes de sua natureza. Veremos ao longo deste trabalho como essa ideia de espaço foi explorada por vertentes diversas. Interessa-nos, no entanto, como a produção artística contemporânea, especificamente trabalhos surgidos a partir da década de 1990, problematizaram esse elemento. Para isso, buscaremos primeiramente nos trabalhos filosóficos de Henri Bergson (2010) e Merleau-Ponty (2014 e 2011) as bases para o pensamento do espaço como um fenômeno mais geral, não necessariamente no que concerne ao território da arte.

A escolha por esses autores se deve ao fato de que, segundo Claire Bishop (2005), ambos influenciaram o pensamento de uma época em que vimos o surgimento de um processo de espacialização dentro da produção de arte que culminou no que conhecemos hoje como 'instalação'. Como será discutido mais a frente, Bishop pontua o surgimento do Minimalismo como um importante fator para o desenvolvimento das práticas instalativas e a influência do espaço como concebido por Merleau-Ponty nessa história. Mas antes de adentrarmos no território da arte contemporânea, pontuemos o que Bergson e Merleau-Ponty podem contribuir para esse pensamento espacial.

Retomando a citação que inicia esse texto, Bergson (2010) nos apresenta um ponto fundamental em seu pensamento, o fato de considerar matéria e espaço dois elementos diferentes que, no entanto, estão entrelaçados. Parece-nos que, nos termos iniciais de Bergson, o espaço é um vácuo constituído por um agregado de matéria, e o autor compreende por matéria um conjunto de imagens. Dentre essas imagens que compõem o espaço uma em especial tem a prerrogativa de exercer ações possíveis sobre as outras, o nosso corpo. Nesse sentido, Bergson institui o corpo como uma entidade que tem poderes em uma instância superior sobre o resto dos elementos que o circundam e formam o espaço. 
Apesar de o autor conferir aos demais elementos que compõem o espaço, à exceção do corpo, um caráter de potencial transformador, é esse corpo o único que realmente tem a possibilidade de gerir modificações possíveis ao seu redor como um "centro de ação", invariável. Esse corpo apreende do mundo aquilo que o atrai de alguma maneira, enquanto os outros elementos circundantes permanecem sem ação consciente. É como se o espaço enquanto totalidade não pudesse nos transformar enquanto elemento autônomo porque dele só tiramos aquilo que toca o nosso corpo conscientemente, aquilo para o qual nos direcionamos e que desemboca em um processo interno que Bergson chama afecção.

Bergson pontua, portanto, que o processo de percepção pura, o contato imediato com o mundo, está fora do corpo, chega a nós a partir de nervos aferentes (fora para dentro), de onde as imagens do mundo tornam possíveis uma modificação de nosso corpo, mas só o influenciam na medida em que nos direcionamos a ela, ou o que o autor chama representação. No entanto, a percepção (que se sucede à percepção pura), como um momento mais complexo e como entendida por Bergson, só se realiza de fato a partir do momento em que devolvemos ao mundo essas ações a partir do processo de afecção, em que nervos eferentes (de dentro para fora) nos possibilitam escolher as imagens do mundo as quais o corpo como imagem modificará. Vemos, portanto, o desenvolvimento de um contínuo em que o exterior nos toca para que possamos devolver ao mundo ações, e esse processo de devolução só poderia ocorrer do interior em direção ao exterior, com a atenção para o fato que já apontamos de que o que vai nos modificar são apenas aqueles elementos do mundo para o qual direcionamos nossa atenção. A percepção desse espaço se dá, nessa medida, do contato puro com o mundo à escolha dessas imagens do mundo que nos interessam. É realmente somente essa escolha quem vai engendrar o espaço.

Se pensarmos nesse sentido o espaço, para Bergson, é essencialmente escolha, e a percepção essencialmente o que se exterioriza do nosso corpo. Portanto, a percepção forma o espaço e esse, por sua vez, é ligado à matéria, como imagem do mundo. Elencamos aqui, portanto, duas categorias primordiais, o espaço como escolha das imagens do mundo, e o espaço como elemento formado por matéria. Desse modo, não podemos pensar o espaço apenas como exterioridade ao nosso corpo, já que a escolha só se dá no processo de afecção (interno ao nosso corpo), o que nos leva a crer, em primeira instância, que espaço para Bergson trata-se das matérias (ou imagens) escolhidas no processo de percepção, e não a matéria do mundo em sua totalidade. A percepção, nesse sentido, elimina de meu campo de atuação as imagens sobre as quais eu não poderia ou não conseguiria exercer influência, fazendo surgir essas imagens que chamo espaço. 
A concepção de espaço perpassa a partir daqui outra importante categoria, a lembrança, pois só nos interessa enquanto escolha de imagens do mundo aquilo que podemos reconhecer, lembrar, e essa lembrança só poderia surgir ao tomarmos emprestados para o nosso corpo um outro corpo (imagem do mundo) que nos faz perceber e devolver ações. A diferença entre a lembrança e a percepção estaria engendrada apenas na intensidade, já que a lembrança é de certa maneira fugaz e só pode ser retomada no contato com as outras imagens do mundo, que não o meu corpo, enquanto a percepção é essencialmente movimento, escolhemos e selecionamos a cada segundo e, desse modo, o espaço como imagens selecionadas só pode ser compreendido também como mutável a cada segundo de seleção e percepção. A matéria aqui coincide com a percepção pura, ela é presente se desenvolvendo no espaço, tudo o que percebemos de imediato a partir dos nervos aferentes. Se matéria é percepção pura, presente, e o espaço seria essencialmente a escolha de matérias, esse mesmo espaço só poderia existir, dessa forma, na ação do corpo sobre as imagens do mundo. O espaço parece existir como presente, porque tudo o que passou já se tornou lembrança, reconhecimento do mundo para a realização de ações posteriores.

Se só pode ser presente, o espaço para Bergson é lembrança atualizada. Não mais aquela lembrança em que vemos armazenada em nosso corpo as nossas ações cotidianas, como uma necessidade natural, sem necessariamente uma utilidade imediata, mas como um prolongamento no presente dessa lembrança conservada. Espaço é disposição para agir, condição de existência, movimento. O espaço nesse sentido só pode existir também na ação do tempo, que é contínuo, se funda nas sensações, esta última como sucessão de estímulos em partes localizadas do nosso corpo, e a qual possibilita o movimento do corpo no mundo. A lembrança passa, portanto, por um elemento mais geral, não localizável pois toma nosso corpo por inteiro, ela é na verdade futuro imediato, ou como já dissemos, passado atualizado e não participa da sensação pois é presente conservado para agir. Espaço se dá no binômio sensaçãolembrança, engendrando nossa memória.

A questão da memória como presentificação de uma lembrança atualizada nos leva a outro importante conceito, o de duração. O fenômeno da duração compõe-se, nesse sentido, pela junção de dois processos: a constituição da imagem interna ao corpo, de onde surge o reconhecimento do mundo a partir das lembranças, e de uma imagem que se externaliza, a nossa ação no mundo enquanto tempo presente. Esse presente, no entanto, trata-se de nada mais do que passado atualizado, daí a importância dada pelo autor à questão da memória para compreender nossas relações no mundo. A duração é contínua, é multiplicidade, tomando o cuidado de compreender essa multiplicidade não nos termos da oposição entre o numericamente 
múltiplo e unitário, mas como simultaneidade de movimento das experiências do passado e presente.

A relação do espaço com a duração é fundante, já que ao serem tomados como essencialmente continuidade parecem se confundir, ou de outra maneira, a duração é a responsável pela fundação da própria compreensão e percepção do espaço. Isso nos leva a crer que Bergson acaba por instituir ao espaço um papel de elemento de certa maneira passivo, que é modificado pelo corpo e as ações potenciais que os elementos do mundo exercem sobre ele. Portanto, o elemento espaço se torna coadjuvante nesse processo em detrimento da duração, em que a temporalidade parece se desenvolver no nível da memória. O espaço só pode ser compreendido no movimento do corpo, passagem de um repouso a outro, para além da simples sensação, pois só podemos compreender essa categoria a partir do momento que agimos sobre a própria sensação que chega a nós de maneira localizada, mas que atua como desencadeador dos elementos internos ao nosso corpo que irão se exteriorizar. Assim, Bergson afirma que:

(...) o espaço é de fato o símbolo da fixidez e da divisibilidade ao infinito. A extensão concreta, ou seja, a diversidade das qualidades sensíveis, não está nele; é ele que colocamos nela. O espaço não é o suporte sobre o qual o movimento real se põe, é o movimento real, ao contrário, que o põe abaixo de si. (BERGSON, 2010, p. 255 256).

O espaço é, portanto, retomado como submetido ao movimento, à continuidade, divisível enquanto ação iminente e constante, ao infinito, não podemos capturá-lo em um momento, pois só existe como prolongamento disso que o autor chama de viver, nossa experiência interna e externa do mundo. Isso traz à tona novamente a concepção de duração e, nesse sentido, Gilles Deleuze (2012) comenta:

(...) trata-se de uma "passagem", de uma "mudança", de um devir, mas de um devir que dura, de uma mudança que é própria da substância. Note-se que Bergson não encontra qualquer dificuldade em conciliar as duas características fundamentais da duração: continuidade e heterogeneidade. Mas, assim definida, a duração não é somente experiência vivida; é também experiência ampliada, e mesmo ultrapassada; ela já é condição da experiência, pois o que esta propicia é sempre um misto de espaço e duração. A duração pura apresenta-nos uma sucessão puramente interna, sem exterioridade; o espaço apresenta-nos uma exterioridade sem sucessão (com efeito, a memória do passado, a lembrança do que se passou no espaço já implicaria um espírito que dura). Produz-se entre os dois uma mistura, na qual espaço introduz a forma de suas distinções extrínsecas ou de seus "cortes" homogêneos e descontínuos, ao passo que a duração leva a essa mistura sua sucessão interna, heterogênea e contínua (DELEUZE, 2012, p. 31). 
O espaço aparece, de maneira ampla, como uma sucessão de partículas de tempo que se congregam e aparecem no tempo mais complexo (que compreenderia passado como lembrança e o passado atualizado na ação) de experiência da duração. Deleuze fala de espaços auxiliares para determinar esses fragmentos, como se a cada um desses fosse capturado, guardado, retomado pela lembrança e exteriorizado, dando assim surgimento ao que poderíamos chamar essa categoria espaço. Ele seria, assim, uma dessas possíveis ampliações da experiência proporcionadas pela duração, conforme comentário de Deleuze.

Deleuze, retomando a questão da multiplicidade a partir de Bergson, institui essa como representada em dois momentos. Primeiro a partir da exterioridade do espaço, em que essa multiplicidade se caracteriza pela simultaneidade, justaposição e de ordem quantitativa, da sucessão dos “espaços auxiliares". Por outro lado, a multiplicidade aparece na duração como o estado interno, de fusão das exterioridades nessa imagem que chamo meu corpo, é qualitativa porque é modificada e modifica a experiência de viver. Essas mudanças que acontecem com os estados de exterioridades só podem existir a partir de uma consciência que as rememora a partir da lembrança. Deleuze reforça Bergson ao acreditar que esse processo só pode existir também a partir do movimento, que é espaço percorrido (quantitativamente) e alteração de estados (qualitativamente). A duração seria, em resumo, a síntese, o elo entre a experiência de exterioridade do espaço e a consciência dessa exterioridade a partir da afecção, o que nos levaria a um estado de percepção.

De maneira geral, podemos dizer que essa categoria espaço, para Bergson, é nada mais do que as imagens do mundo que a nossa percepção escolhe para atuar sobre. Essa atuação revela, desse modo e como já elencado, o potencial transformador e a prerrogativa do corpo sobre as imagens do mundo. Essas imagens do mundo selecionadas, que agora chamo espaço, são, portanto, movimento presente, ação do corpo sobre o mundo ao qual minha percepção voltou sua atenção. Espaço é sim as imagens que me rodeiam, no entanto, apenas as imagens para as quais volto minha atenção e modifico, interna e externamente, para devolver ao mundo.

Bergson mesmo pontua seu estudo em Matéria e Memória, publicado originalmente em 1939, como claramente dualista, fazendo uma diferenciação clara entre matéria e espírito, corpo e espaço, processos internos e externos. A questão do corpo reaparece nos últimos escritos de Merleau-Ponty, publicados originalmente em 1964, e parece dialogar de alguma maneira com Bergson. Merleau-Ponty (2014) também acaba ligeiramente considerando o corpo como uma imagem do mundo que se destaca em relação às outras, conforme trecho abaixo reproduzido: 
Pois, se o corpo é a coisa entre as coisas, é num sentido mais forte e mais profundo do que elas, é dizíamos, que é delas, e isso quer dizer que se salienta em relação a elas (e, nessa medida, delas se separa). Não é simplesmente coisa vista de fato (não vejo minhas costas), é visível de direito, cai sob uma visão ao mesmo tempo inelutável e diferida. (MERLEAU-PONTY, 2014, p. 133-134).

O que diferencia, no entanto, o trabalho de Merleau-Ponty com relação à Bergson é a maneira como esse corpo se relacionará com essas outras imagens do mundo. Apesar de ainda diferenciar-se com relação às outras imagens, o corpo para Merleau-Ponty não necessariamente é um objeto privilegiado, pois é tocado pelas imagens no mundo na mesma medida em que as toca, torna-se a partir daqui um sensível-sensiente. O que circunda nosso corpo não é mais simplesmente objeto da nossa ação potencial sobre eles, mas eles mesmos nos modificam. Se para Bergson, ao que nos parece, o espaço é as próprias imagens do mundo, esse mesmo espaço agora em Merleau-Ponty é um vetor de transformação equivalente ao nosso corpo.

As imagens do mundo não existem mais por si só, pois só podem estar no mundo se pensadas como o que o autor chama de "raios de espacialidade e temporalidade", na imbricação entre todas essas imagens. Portanto, só existe espaço se existem coisas no mundo (o que Bergson chama imagens do mundo). Dentre essas coisas, meu corpo precisaria de um importante processo para se colocar no mundo, a abertura para este último, de modo a compreender que existem estados que estão acima de nós mesmos, que nos modificam mesmo que não tenhamos total consciência disso. Levantamos aqui, portanto, a questão da deiscência, a abertura para o mundo de maneira que o sensível-sensiente apareça. Sobre esse binômio e a relação com a deiscência, Merleu-Ponty declara:

Não há, portanto, coisas idênticas a si mesmas, que, em seguida, se oferecem a quem vê, não há um vidente, primeiramente, vazio, que em seguida se abre para elas, mas sim algo de que não poderíamos aproximarmo-nos mais a não ser apalpando-o com o olhar, coisas que não poderíamos sonhar ver 'inteiramente nuas', porquanto o próprio olhar as envolve e as veste com sua carne. (MERLEAU-PONTY, 2014, p. 128).

É preciso que entre a exploração e o que ela me ensinará, entre meus movimentos e o que toco, exista alguma relação de princípio, algum parentesco, segundo o qual não sejam somente, como pseudópodos de ameba, vagas e efêmeras deformações do espaço corporal, mas iniciação e abertura a um mundo táctil. Isso só poderá acontecer se, ao mesmo tempo que sentida do interior, minha mão também for acessível por fora, ela própria tangível, por exemplo, pela outra mão, se tomar lugar entre as coisas que toca, sendo, em certo sentido, uma dentre elas, abrindo-se, enfim, para um ser tangível de que também ela faz parte. (MERLEAU-PONTY, 2014, p 130).

Essa estrutura fundamental apresentada acima por Merleau-Ponty é o que o autor chama Quiasma, uma identidade na diferença. Termos como vidente e visível, interior e exterior, tocante e tocado só podem ser eles mesmos sendo o outro ao mesmo tempo. Isso nos interessa 
para pensar como o espaço atua nessa direção de sensível-sensiente, acordando que o espaço nos toca na mesma ordem que o tocamos, portanto, é não apenas fonte de sensações, não apenas oferece imagens para os nervos aferentes, como o parecia para Bergson. Para Merleau-Ponty a relação não é unilateral, mas de complementariedade.

Devemos tomar o cuidado, no entanto, de pontuar que o autor não trata aqui de conferir a todas as imagens do mundo uma coincidência de existência, como se cada uma fosse igual à outra. A relação em outro sentido é não de fusão, mas de fissão, encontro, imbricação, recobrimento, e é justamente a deiscência quem proporciona essa consciência de um certo nível de divisão entre o eu e o outro. A deiscência nos torna consciente de uma distância que existe entre as imagens do mundo, onde um certo elemento, que Merleau-Ponty chama Carne, se prolonga e possibilita aquilo que pontuamos anteriormente como "raios de espacialidade e temporalidade". Retomando, não posso dizer que olho para as coisas, que me espacializo sobre elas, porque ao mesmo tempo podem ser as coisas do mundo que me fazem olhar para elas.

Essa Carne é elemento de comunicação entre vidente e visível, seria a presença desse elemento, a carne do mundo em minha carne que possibilitaria "(...) nos incorporarmos ao universo, como duas metades de uma laranja" (MERLEAU-PONTY, 2014, p. 130). Sobre a carne, Merleau-Ponty pontua:

\footnotetext{
A carne não é matéria, não é espírito, não é substância. Seria preciso, para designá-la, o velho termo 'elemento', no sentido em que era empregado para falar-se da água, do ar, da terra e do fogo, isto é, no sentido de uma coisa geral, meio caminho entre o indivíduo espácio-temporal e a ideia, espécie de princípio encarnado que importa um estilo de ser em todos os lugares onde se encontra uma parcela sua. Neste sentido, a carne é um 'elemento' do Ser. (MERLEAU-PONTY, 2014, p. 136).
}

Partindo desse princípio, a carne seria justamente esse elemento que se encontra entre a imagem-lembrança e a imagem-ação de Bergson, o elemento motivador do movimento, da ação no mundo, pois possibilita a consciência do Ser e do estar entre outros Seres, fundante da Duração. Esse movimento é, portanto, essencial para que compreendamos o espaço, pois possibilita o surgimento de uma categoria que Merleau-Ponty irá se ater em sua Fenomenologia da Percepção originalmente publicado em 1945, a profundidade, e o abandono desta por meio do movimento. À questão da profundidade ele parece conferir um protagonismo que gera assim uma relação com outras categorias pelas quais ele se interessa em definir. O sensível e o sensiente, transpassados por esse elemento Carne, seriam como a superfície de uma profundidade inesgotável. Se a condição de sensível e sensiente só existe pela Carne, por esse acoplamento, e a Carne é elemento de profundidade, seria a Carne também fundadora da noção 
de espaço? Acreditamos que sim, já que para Merleau-Ponty (2014) a existência é espacial, e a existência só pode ser pensada porque existe uma carne que liga as coisas do mundo, essa carne é, portanto, elemento constituinte do espaço.

Para desenvolvermos essa questão, vamos nos ater nesse momento em definir o que Merleau-Ponty compreende como profundidade. Em primeiro lugar o autor delimita que essa categoria só pode surgir a partir do meu olhar porque ele busca ver algo no mundo, sendo a dimensão espacial em que as coisas do mundo, inclusive meu corpo, se relacionam umas com as outras. Acreditamos, portanto, ser o lugar onde reside o quiasma, aquela identidade na diferença, e de onde emerge a deiscência.

Na profundidade nos vemos envoltos e por isso abrimo-nos para as possibilidades de modificação mútua do mundo. Para o autor essa categoria profundidade se diferenciaria da largura e altura porque nessas as coisas do mundo se justapõem e não se envolvem. Se a profundidade é uma noção fundante da compreensão do espaço, e esse último é essencialmente o entrelaçamento das coisas do mundo, então a função da profundidade seria a de possibilitar “(...) o conhecimento das relações espaciais entre os objetos e de seus caracteres geométricos que um sujeito desinteressado pode adquirir” (MERLEAU-PONTY, 2011, p. 377).

Percebemos uma certa similaridade entre o que Merleau-Ponty chama profundidade e esse elemento que em seus últimos escritos chamará Carne, com a diferença importante de que a profundidade pode ser percebida a partir de dois importantes elementos, a distância e a grandeza aparente com relação aos objetos do mundo, que se percebem por diferenciação de massas, enquanto a carne parece inalcançável por só pode ser percebida se de fato me abro para a atuação do mundo, se a deiscência acontece.

Acreditamos que esse conhecimento das relações espaciais entre as coisas do mundo deve estar, portanto, intimamente ligado ao reconhecimento do acoplamento entre a carne do meu corpo e a carne do mundo. No entanto, como elemento, a carne do mundo não é visível, dessa maneira como poderíamos alcançá-la? Aí parece residir um reforço àquela função da profundidade, que não sendo também visível, pode ser alcançada pelas próprias coisas do mundo. A profundidade seria o ambiente propício para aquele momento em que me abro pro mundo, vejo os objetos que o constituem e consigo reconhecer entre eles uma distância que é relativa na medida em que abandono o lugar em que meu corpo se encontra previamente para me aproximar ou distanciar.

O reconhecimento das distâncias entre meu corpo e os objetos e entre os próprios objetos se dá justamente pela grandeza aparente deles, que se tornam borradas a medida em que me movimento e aumento o intervalo do meu corpo entre elas, e mais nítidas a medida em que me 
aproximo delas. O jogo entre diminuição e aumento desses intervalos é quem faz surgir a profundidade. É nesse momento de proximidade, que não é restritamente físico, que a carne do mundo e a carne do meu corpo tomam proporções maiores de acoplamento, me relaciono com essas coisas do mundo e esse elemento carne que as constitui passa a me constituir cada vez mais também. Portanto, apreender o espaço de maneira mais complexa perpassaria também uma apreensão mais aproximada dessas carnes por meio do jogo com as distâncias e grandezas aparentes.

Embora tenha em primeira instância efetuado uma diferenciação entre profundidade e largura, Merleau-Ponty retoma essas categorias para relacioná-las. Segundo o autor, a profundidade poderia ser entendida como na realidade uma largura vista de perfil, também uma justaposição de pontos comparáveis à largura. É importante rememorar o fato de que nessa profundidade existe um intervalo entre meu corpo e as coisas, e é este intervalo, distância, que me motiva ao abandono do lugar e o surgimento dessa situação em que profundidade pode se tornar largura, pois minha visão alcança os objetos sob outro ponto de vista. É esse abandono, no entanto, quem possibilitará a nossa compreensão de espaço, pois é nele que reside o meu potencial transformador do mundo, a mobilidade.

Essa mobilidade pressupõe, portanto, que somos seres orientados, que nossa existência é orientada e, portanto, espacial. O que nos parece ficar mais latente no pensamento de MerleauPonty é que a definição de espaço não deve ser tomada como algo que está fora de nós, pois só existiria de fato em nossa percepção. Aqui é importante pontuarmos que para Merleu-Ponty, essa percepção toma caminhos diferentes nos seus últimos escritos. Enquanto antes era entendida como nosso contato ingênuo com o mundo, como um processo inerente e que acontece a todo momento da existência, em seus últimos anos de trabalho passa a considerar a percepção como a soma da percepção banal, cotidiana (que antes era entendida como a totalidade da percepção e que o autor passa a preferir chamar experiência-fonte), o passado (lembrança) e a linguagem, uma devolução intelectual de possível modificação do mundo.

Essa relação entre as noções de espaço e percepção ficam um pouco mais evidentes ao compararmos, por exemplo, essas diferenciações acima relatadas às concepções de espaço espacializado e espaço espacializante apresentadas por Merleau-Ponty em sua Fenomenologia da Percepção. Entre essas noções parece residir um fator de maior ou menor grau de consciência do meu corpo enquanto potencial modificador deste espaço em que habita. Desse modo, o espaço espacializado seria descrito pelo autor numa situação em que: 
Não reflito, vivo nas coisas e considero vagamente o espaço ora como o ambiente das coisas, ora como seu atributo comum. Meu corpo e as coisas, suas relações concretas segundo o alto e o baixo, a direita e a esquerda, o próximo e o distante podem aparecerme como uma multiplicidade irredutível; Lido como o espaço físico, com suas regiões diferentemente qualificadas (MERLEAU-PONTY, 2011, p. 328).

Por outro lado, o espaço espacializante se caracterizaria pela situação em que:

Reflito, retomo o espaço em sua fonte, penso atualmente as relações que estão sob essa palavra, e percebo então que elas só vivem por um sujeito que as trace e as suporte. Descubro uma capacidade única e indivisível de traçar o espaço. Lido com o espaço geométrico cujas dimensões são substituíveis, tenho a espacialidade homogênea e isotrópica (mesma direção), posso pelo menos pensar uma pura mudança de lugar que não modificaria em nada o móbil, e por conseguinte uma pura posição, distinta da situação do objeto em seu contexto concreto. (MERLEAUPONTY, 2011, p. 328).

Entre essas duas noções parece residir justamente a diferenciação que Merleau-Ponty passa a fazer entre a experiência-fonte (antes percepção) e a agora percepção. Diante desses dois estados do corpo no espaço a percepção parece tomar um sentido de construção intelectual, onde um espaço espacializante realmente surge, modificado, onde me vejo como corpo orientado, realizo movimento como não apenas passagem de um repouso a outro, mas relação com os objetos que me tocam. No espaço espacializante o sensível-sensiente toma forma. É importante, no entanto, pontuar que entre essas duas vertentes de um mesmo espaço não existe uma relação de hierarquia, não significa que ao ser espacializante esse espaço se torna de alguma maneira mais complexo, é como se ao ser espacializado e espacializante o espaço se fundasse.

Estamos até aqui falando, portanto de um espaço que é comumente chamado espaço físico, formado por uma largura, uma altura e uma profundidade, experiência de tridimensionalidade, sendo a profundidade, como já visto acima a partir de Merleau-Ponty, uma categoria fundante dessa concepção. Partindo ainda de Merleau-Ponty, podemos verificar que aquilo denominado intervalo denota a existência de um vácuo espacial que em tempos anteriores era sequer considerado. Margareth Werthein (2001) ao buscar reconstruir uma história dos pensamentos sobre o espaço mostra como Aristóteles renegava a existência desse vácuo espacial, desse intervalo entre as coisas. Segunda a autora, para Aristóteles, o espaço seria nada mais do que uma superfície superfina que separaria todas as massas que compõem o universo, ou seja, não haveria intervalos entre, onde uma acaba outra necessariamente começaria.

Essa camada superfina que envolve cada objeto do mundo, um ponto de ligação entre tudo que existe parece a nós conferir a esses objetos uma certa imobilidade, já que não há 
intervalos a serem percorridos, e poderia, portanto, desembocar em um conhecimento recíproco tão profundo que levaria ao que Bergson e Merleau-Ponty se preocuparam em delinear como não existente, a coincidência exata entre as coisas do mundo. Se não há intervalo, não poderia haver movimento, e se não nos deslocamos não poderia haver um espaço espacializante, que refletimos e modificamos. Se essa superfície superfina fosse como um elemento de colagem entre os objetos existentes no mundo tudo acabaria se tornando tão próximo que aquele elemento Carne de que Merleau-Ponty falava não poderia existir, já que é ele que nos liga mas também nos separa, faz surgir o quiasma, aquela identidade na diferença. As ideias de Aristóteles foram, portanto, bastante criticadas e os posicionamentos reflexivos acerca do espaço tomaram outros rumos a partir da admissão pela ciência moderna da existência de um vácuo espacial dotado de extensão, intervalo e profundidade, conforme explicita Werthein:

\footnotetext{
Em sua nova imagem do mundo o 'espaço físico' tornou-se finalmente sinônimo de espaço euclidiano, um vazio tridimensional sem traços característicos. Finalmente, após dois mil anos, Aristóteles fora derrotado - o vazio passara a ser visto como a própria base da existência. Como o dos atomistas antigos, o universo de Galileu consistia unicamente de matéria e vazio. Para ele, 'o mundo real [era] um mundo de corpos que se moviam no espaço e no tempo. Tudo mais - todas as ricas qualidades sensuais, como cores, cheiros, gostos e sons - devia agora ser considerado meramente secundário, subprodutos da 'verdadeira' realidade, que era matéria em movimento num espaço vazio. (WERTHEIN, 2001, p. 88).
}

Obviamente esse pensamento das questões consideradas secundárias encontra pouco ou nenhum encontro com trabalhos como os de Merleau-ponty e Henri Bergson, para os quais elas são essenciais na constituição do espaço entendido em sua dimensão de experiência. A partir das pontuações desse espaço como formado por um vazio onde massas se movimentam uma série de outras questões começam a surgir, e o número de dimensões espaciais se ampliou a tal ponto que, segundo Werthein, determinados físicos teóricos chegaram a compreensão da existência de onze dimensões espaciais, o que chamaram de um hiperespaço. Essas outras dimensões que se estendem para além das dimensões euclidianas da altura, largura e profundidade seriam, no entanto, elementos ocultos, que fogem a uma percepção consciente e existem em um nível molecular, sendo, portanto, formadoras do espaço euclidiano como o compreendemos.

Não queremos, no entanto, nos ater aqui às teorias da física acerca do espaço e suas diversas dimensões, já que nos levaria a uma série de problematizações que podem nos distanciar dos objetivos principais desse estudo. Porém, um fator que transborda a geometria de três dimensões nos interessa, o tempo. O tempo como um elemento que garante a experiência do espaço foi, segundo Werthein, posta em questão a partir de meados do século XIX e 
principalmente, a posteriori, pelos estudos da relatividade de Albert Einstein. A consideração do tempo como uma dimensão que está intrinsecamente atrelada ao espaço deve ser considerada, principalmente se levarmos em conta a natureza da outra variável que compõe nosso estudo, o vídeo, um tipo de imagem que é temporalizada.

A natureza de imbricação do tempo no espaço torna-se clara se retomamos a concepção de duração de Henri Bergson e os comentários de Deleuze acerca da existência dos "espaços auxiliares" para a formação do espaço como um todo, sendo esses primeiros nada mais do que partículas de tempo que se apresentam à nossa percepção para que possamos assim agir no mundo, é o processo temporal da duração (entre passado e presente, como passado atualizado) que reside o espaço como memória motora.

Até aqui nos preocupamos em levantar algumas questões referentes às concepções desse espaço justamente para delimitar de que espaço estamos falando. Portanto, nesse momento pontuamos que falamos até então de um espaço físico, formado pelas dimensões da altura, largura e profundidade, tomando essa última como a principal fundadora dessa noção em Merleau-Ponty, e também uma quarta e importante dimensão, o tempo, conforme nos debruçamos a partir de Henri Bergson. É para esse espaço físico que propostas de videoarte se expandirão e de onde aparecerão as operações e modos de espacialização que discutiremos mais a frente em nosso trabalho.

Esse espaço quadridimensional, como já dito no início desse texto, tem sido retomado, estudado e problematizado por experiências que se inserem em diversos campos do conhecimento humano, da filosofia à física. Interessa a nós, a partir daqui, tentar elencar a construção de estratégias para a representação dessa categoria espaço a partir de imagens bidimensionais. Esse parece ser um esforço que perpassa na realidade toda a história da humanidade e vem acompanhando as próprias concepções que o espaço vem sendo tomado.

Margareth Werthein cita, por exemplo, os esforços de Giotto (1267-1337) no século XIV para a elaboração de mecanismos de representação desse espaço em suas pinturas como um dos mais sofisticados ao longo da história da arte, e mais, como o pontapé para o aumento pelo interesse pela representação empírica de um mundo físico, do que viam de fato, que fosse além das representações imaginárias de um espaço celestial, muito embora as temáticas celestiais ainda se fizessem completamente presentes na época.

O que vimos foi o fortalecimento de uma visão geométrica do espaço, a potencialização da tentativa de representação desse espaço físico por meio da ilusão de profundidade, simulação de tridimensionalidade, de modo que pudéssemos visualizar nessas imagens um espaço que é contínuo e homogêneo, onde as grandezas de escala e coincidência de ponto de vista fossem 
tão fortes que nos levassem a acreditar nesse espaço representado, uma tentativa de simulação do campo visual humano. Essas elaborações foram fortalecidas e organizadas principalmente a partir do século XV nos trabalhos pictóricos de artistas como Leonardo, Rafael, entre outros, que no âmbito da Renascença organizaram um conjunto de regras representacionais que ficou conhecida como a Perspectiva linear. A questão da profundidade surge novamente nas discussões do espaço, agora na sua tentativa de representação.

Obviamente, na passagem dessa história uma série de movimentos artísticos se preocuparam em desconstruir essas regras e apresentar por meio da imagem bidimensional outras perspectivas de representação espacial, é o caso do cubismo e futurismo, por exemplo, na pintura, e o que discutiremos mais a frente acerca das incursões do vídeo nesse âmbito. Acreditamos falar aqui, portanto, da composição de um quadro, delimitação de representação em uma imagem e como os elementos que a constituem são organizados nesse campo delimitado. Para pensarmos acerca desses elementos organizacionais que compõem a imagem e a representação bidimensional nos ateremos no próximo item aos estudos de Jacques Aumont (2005 e 1993), para falar dessa imagem em um âmbito mais geral e Nöel Burch (2014) para que possamos inciar nossa incursão no campo do audiovisual.

\title{
1.1 ESPAÇO E REPRESENTAÇÃO
}

\begin{abstract}
A perspectiva é uma transformação geométrica, que consiste em projetar o espaço tridimensional sobre um espaço bidimensional (uma superfície plana) segundo certas regras, e de modo a transmitir, na projeção, uma boa informação sobre o espaço projetado; de maneira ideal, uma projeção perspectiva deve permitir que se reconstituam mentalmente os volumes projetados e sua disposição no espaço. As regras dessa transformação são muito variáveis, e existe, geometricamente falando, uma grande quantidade se sistemas perceptivos, pelo menos potenciais. (AUMONT, 1993, p. 222).
\end{abstract}

Ao falar sobre a perspectiva, a qual levantamos no tópico anterior, Jacques Aumont (1993) reitera suas características como representação ilusória de um espaço e, para além, chama atenção para o fato de que essa representação sempre esteve ligada à concepção de espaço de determinado período histórico, portanto, não poderíamos dizer que a perspectiva renascentista e sua representação seria mais realista do que qualquer outra, mas sim que reflete os desenvolvimentos dessa própria concepção de espaço nessa época.

Avançando na discussão da imagem, Aumont pontua a importância da noção de campo como um fechamento, um corte do visível, aquilo que estaria, desse modo, enquadrado na 
imagem, um recorte do espaço e regimentado por um ponto de vista. O campo, para além do enquadramento (que seria justamente a atividade de delimitação do campo), guarda também a característica de ser um espaço representado em profundidade em uma superfície plana. Esse mesmo campo pressupõe a existência de um fora de campo, que não está enquadrado, mas que pode ser imaginado, e na imagem em movimento esse fora de campo está sempre em vias de ser desvendado por um movimento que equivaleria ao movimento da câmera tomada de um novo ponto de vista, que pode ser visualizado também pela existência do contra-campo. Dentro dos estudos do autor, alguns conceitos específicos interessam-nos, dentre eles, portanto, a perspectiva e a questão do campo. Dentro desse campo, o autor define algumas relações possíveis de composição: 1) a superfície, composição ou relação geométrica entre as partes da imagem; 2) a gama de valores, ligadas à luminosidade e contraste; 3) a gama de cores; 4) os elementos gráficos, tal como linhas e formas e 5) a matéria da imagem.

Todos esses elementos estão obviamente entrelaçados e caminham para construção de uma narrativa, seja na imagem fixa ou na imagem em movimento, e que para Aumont (2005) trata-se do emprego das noções de causalidade e acontecimento, este último como o resultado de atividades diversas no quadro. Qualquer acontecimento e suas causalidades só podem existir dentro de um espaço que o abriga, onde um espaço imaginário existe e é construído pelo movimento dos elementos compositivos. A narrativa, portanto, informa a natureza do espaço que é apresentado na imagem a partir de elementos como a profundidade de campo, os ângulos, os olhares, os enquadramentos.

Esses elementos elencados seriam assim os mais básicos para a constituição de uma imagem, a partir de sua organização dentro do campo. Desse modo, as características fundantes de uma representação mais ou menos realista do espaço se dão na tentativa de simulação da profundidade. Esses elementos serão integrados no espaço plástico da imagem, segundo nomenclatura de Aumont (1993), que se diferenciaria do espaço concreto (ou espaço físico) em que essa imagem se encontra localizada e é visualizada. Nos ateremos, neste momento às questões que dizem respeito a esse espaço plástico e como as organizações espaciais acontecem. Desse espaço plástico, Jacques Aumont apresentará alguns importantes elementos que se referem diretamente às questões de espacialidade.

Optamos por organizar em tópicos esses elementos para, assim, verificarmos como eles se desdobram na imagem audiovisual a partir dos estudos de Nöel Burch posteriormente. Embora este último autor detenha seus estudos no cinema, mais especificamente aquele feito com película, muitas de suas observações são pertinentes ao universo videográfico e às questões de espacialização do vídeo das quais trataremos no terceiro capítulo deste trabalho. Portanto, a 
partir deste momento, e neste capítulo, passaremos a utilizar o termo audiovisual para nos referirmos às imagens em movimento de modo a conferir aos estudos destes autores uma qualidade mais ampla.

Retomando Aumont (2005), uma categoria essencial para pensar as questões espaciais da imagem é o quadro, como o que delimita a imagem, faz com que ela não seja infinita e indefinida. $\mathrm{O}$ autor institui que esse quadro deve ser definido pelo que contém tanto pelo que não contém, não aparece em suas delimitações, conforme citado acima acerca do fora de campo e do contra-campo. Esse quadro, segundo Aumont, poderia existir a partir de delimitações espaciais em três naturezas distintas, que podem aparecer concomitantemente, conforme descritas abaixo:

1) Quadro-objeto: Trata-se do enquadramento material, da moldura enquanto objeto físico que delimita o campo, algo como um entorno arquitetural que rodeia a obra e liga à imagem a um valor de objeto móvel, comercializável e confere certo status à imagem.

2) Quadro-limite: Trata-se do limite material da imagem, o limite da tela de pintura, o limite do papel fotográfico, limite da tela do cinema, limite da tela no aparelho de televisão, por exemplo. Esse quadro regularia dimensões e proporções internas e é responsável pelo surgimento de um discurso naquele espaço delimitado da imagem, levando à reflexividade sobre esta. Portanto delimita e diferencia o espaço plástico do espaço concreto.

3) Quadro-janela: Refere-se aos limites do campo, na relação também com o que está fora deste. Este quadro é, desse modo, o responsável pela associação entre o caráter plástico das imagens e sua força imaginativa a partir do que estaria fora dela. Dá ênfase, portanto, às bordas como elemento que estabelecerá essa ligação do que nos é dado a ver e do que pode ainda ser visto, principalmente se pensarmos no já falado potencial desvelamento do fora de campo que a imagem em movimento proporciona.

A partir dessas três noções fica claro portanto que a questão de delimitação do alcance da imagem não pode ser claramente definida pelas suas bordas como simplesmente delimitadoras, cortes, já que isso que o autor chama de um quadro-janela pressupõe a existência e consciência do universo espacial no qual aquele enquadramento foi realizado. O quadro-janela estaria numa aproximação com a fantasia porque, ao trabalhar as bordas como limites que se estendem, conferir a estas uma importância de alto grau, revela as possibilidades de existência 
e imaginação do que está para além do enquadramento. Desse modo, quadro-limite e quadrojanela trabalham juntos na realização de processo de delimitação e expansão do quadro, sendo um necessário para que o outro efetive suas funções.

Esse quadro-janela teria desse modo uma relação direta com outro elemento compositivo que Aumont irá se ater, o desenquadramento. Essa operação se caracterizaria pelo deslocamento das zonas mais significantes da imagem para as bordas, retirando-as do centro, como um enquadramento desviante. Atentemos que esse desenquadramento não pode ser entendido como uma simples descentralização, que seria apenas um avesso da centralização, mas caracteriza-se por três traços principais:

1) Desenquadramento e centramento: É onde reside de fato o descentramento, esvaziamento do centro da imagem de objetos significativos.

2) Desenquadramento e bordas da imagem: Acentuação das bordas da imagem com objetos significativos, que podem muitas vezes aparecer cortados, incompletos, interrompidos, para sugerir uma continuidade fora.

3) Desenquadramento e sequencialidade: Trabalha o dispositivo na ordem da relação entre imagem e espectador. Torna-se mais forte nas imagens em movimento por sugerir um movimento e alternância constante entre borda e centro, mantém a descentralização subordinada também ao tempo, e, desse modo, à busca constante do espectador por retomar essas relações, que é mais fácil de ser retomada ou abandonada na imagem fixa.

Para o autor o desenquadramento funda uma estética de espacialidade, um fenômeno estilístico, que coloca em cheque a centralização clássica, das figuras renascentistas, por exemplo, conferindo uma ênfase ao quadro como limite, no sentido de poder se estender, e que é potencialmente mutável no audiovisual, deve ser apreendido a cada instante. Essa ideia de desenquadramento fundaria outro importante elemento, a deformação, como uma apresentação do oposto da forma representativa convencionada pelo centro, fabricada para imitar o espaço físico e o ponto de vista do olho humano. A deformação está portanto baseada na existência de códigos dos quais deve se distanciar, uma maneira mais abstrata de representar esse espaço, que pode ir de apenas um distanciamento tolerável dessas convenções com deslocamentos do tema de uma imagem à composições que quebram completamente com essas regras para a construção de outras modalidades de representação. À abrangência desses diversos mecanismos de 
deformação é o que Aumont chamará expressividade, uma série de recusas das aparências, das convenções, da representação, da reprodução. Um trabalho composicional outro com a forma da imagem para o estabelecimento de distorções.

A história da arte está repleta de exemplos dessa deformação como recurso estilístico, na pintura, no cinema, na escultura, entre outros. É expressamente essa deformação do espaço de representação e suas extensões para o espaço físico que nos preocuparemos em analisar a partir do segundo capítulo deste trabalho, trazendo exemplos de mecanismos utilizados por artistas contemporâneos para sua efetivação.

Esse fenômeno compositivo ao qual Aumont denomina deformação parece estar incorporado a outro levantado por Nöel Burch, as estruturas de agressão, que inevitavelmente causam um mal-estar no espectador, agridem como já vislumbra seu nome, seja por meio da forma ou por meio do tema tratado. Burch é também responsável pelo estudo de uma série de elementos referentes à questão da espacialidade na imagem, especificamente no que se refere ao cinema. Para compreender como o espaço é organizado no cinema, o autor recorre a conceitos como os de decupagem, o raccord, os aspectos de continuidade e descontinuidade entre planos e, muito importante, a questão das dialéticas que se estabelecem na produção cinematográfica,

Comecemos então rememorando uma questão que já foi levantada por Jacques Aumont, e que Burch tratará como o "espaço-da-tela" e o "espaço-fora-da-tela", sendo o primeiro tudo o que olho percebe no espaço delimitado da tela (daquele diálogo entre o quadro-limite e o quadro-janela do qual falamos anteriormente). Já o espaço-fora-da-tela divide-se em seis segmentos de espacialidade. Os quatro primeiros referem-se aos limites imediatos marcados pelos quatro cantos da tela: acima, abaixo, direita e esquerda, para onde o além disso só pode ser imaginado ou desvelado a partir do movimento de câmera. Um quinto espaço encontra-se atrás da câmera, ou o contra-campo por assim dizer. O sexto espaço é determinado, por fim, pelos elementos que se escondem atrás dos cenários ou objetos que compõem o espaço-da-tela.

Nöel Burch aponta para um importante fator que é a importância que deve ser dada ao fora-da-tela tanto quanto ao que está enquadrado na tela e levanta a questão de como o quadro vazio pode ser evocativo para o interesse pelo espaço imaginativo que está fora da tela, enumerando inclusive alguns outros mecanismos para que essa situação de estabeleça, tais como o olhar em off do personagem e a mobilidade para fora de um dos seis segmentos da tela. A relação se dá, portanto, na seguinte direção: quanto maior o esvaziamento do quadro, maior será o interesse pelo espaço-fora-da-tela, quanto mais cheio o quadro, maior atenção será dada para a tela. O esvaziamento do quadro causaria algo como uma expectativa pelo acontecimento 
que está por vir e está se desenrolando no fora-da-tela, o espaço imaginário do fora agindo sobre o espaço concreto do dentro, do quadro delimitado.

À medida em que avançarmos nesse estudo, verificaremos como os espaços de instalações conferem uma outra significação a esse espaço fora, que deixa de ser apenas imaginário para dialogar com o espaço físico em que o vídeo, que em alguns casos apresentam narrativas mínimas, está localizado e pelo qual os observadores construirão experiências. Retornando a Nöel Burch, o cinema seria essencialmente dialético, e é por essas dialéticas que se constituem muito dos mecanismos de espacialidade, seja dentro do quadro, na transição entre planos, no fora-da-tela conforme descritos abaixo:

1) Dialéticas de estilo: existem ao nível do plano e da mudança deste, gerando estruturas maiores que aparecerão em sequências ou no filme em sua totalidade. Está relacionado a questões como raccord e suas orientações espaciais estáticas ou dinâmicas e as transições utilizando elementos como a fusão e sobreimpressão.

2) Dialéticas fotográficas: pode existir entre planos, entre sequências ou dentro do próprio quadro. Refere-se a parâmetros fotográficos como difusão e definição e valores luminosos como contraste e tonalidade (ou brilho).

3) Dialéticas orgânicas: aparecem muito mais ao nível das sequências e estão relacionadas a questões como a presença e ausência de imagem, presença e ausência de som, imagem em movimento e imagem congelada, recuo e avanço da câmera no quadro, entre outras.

Acreditamos que todas essas dialéticas influenciarão decisivamente na construção espacial do quadro assim como a medida no qual o espaço fora-da-tela será tratado, já que em termos se confunde com a própria noção de estrutura na imagem cinematográfica. Para além disso o autor ainda pontua que uma série de outras dialéticas ainda podem surgir, como no diálogo, entre atores, cenários, figurinos, maquiagem. $\mathrm{O}$ autor faz referência ainda a uma outra dialética que chama dialética da imagem, mas pontua que uma simples alternância de imagens no quadro, sem o diálogo com outras dialéticas, não conseguiria construir por si só a totalidade de um filme. Verificaremos mais à frente como essa dialética pode servir como uma base importante para a construção da poética da videoarte.

Outro ponto importante levantado por Burch é a da dialética que ele diz ser a mais importante do cinema, a que reside na relação entre som e imagem. Aqui vemos aparecer, 
portanto, um elemento que deve estar presente sempre quando falamos em audiovisual, o som, e devemos retomar sua importância nas práticas de composição do espaço. O autor elenca alguns fatores importantes tais como o potencial evocativo que o som conferirá ao espaço forada-tela em todos os seus segmentos, e que pode ser incorporado a partir de duas matérias sonoras: o som direto e o som reconstituído pela mixagem. Essa presença sonora pode, no entanto, opor-se a presença visual de alguma maneira, criando tensões que só a existência dessa qualidade de som poderia engendrar. Espacialmente falando, a proximidade do tema sonoro em oposição ao distanciamento do tema visual é um dos principais recursos de uma certa deslocalização e, portanto, deformação nos termos de Aumont (2005).

Nessa linha de pensamento, os três elementos principais a serem trabalhados nessa composição sonora seriam para Burch a música, os diálogos e os ruídos, ampliados ou suprimidos de acordo com intenções diversas. Vale ressaltar que alguns dos conceitos já citados aqui, como a deformação, são estendidos a essa categoria como possibilidade de ação de expressividade nos conteúdos audiovisuais para lidar com as questões de espacialidade. No que se refere à música, por exemplo, Burch cita a possibilidade da interferência do acaso, que podemos claramente verificar nas práticas contemporâneas de performance audiovisual ao vivo, por exemplo.

Todos esses conceitos e categorias aqui elencadas serão, portanto, essenciais como parâmetro para análise dos trabalhos em videoarte que se seguirão nos próximos dois capítulos, daí a necessidade de levantar e apresentar do que se tratam essas relações espaciais da imagem, seja no dentro-da-tela ou no fora-da-tela. Um dos caminhos a serem percorridos é o da investigação da resignificação desse espaço imaginário fora da tela nas instalações, sem perder de vista como esse espaço interno ao quadro também apresenta estratégias de espacialização que residem no jogo entre a continuidade e descontinuidade, o desenquadramento, a deformação, a partir de mecanismos diversos de atuação dos artistas contemporâneos.

Neste tópico nos atemos, portanto, a elencar essas categorias que podem atuar numa espacialização interna da imagem, uma organização, composição. No entanto, queremos retornar agora ao espaço do qual falávamos no início deste capítulo, aquele que Merleau-Ponty chama um espaço fenomenológico. Aqui retomamos também Jacques Aumont (1993) para lembrar que essa mesma imagem que busca representar um espaço é também um objeto no mundo, dotado de dimensões físicas e percebidas como um elemento desse espaço físico em que está localizada. Sobre isso, Aumont declara: 
Há, rigorosamente falando, vimos, dois sentidos do espaço: o espaço quinestético, aquele do toque e do movimento, infinito, isotrópico, homogêneo, tridimensional, cujo modelo rigoroso é o espaço cartesiano. E o espaço visual, não infinito, não isotrópico, não homogêneo, cuja tridimensionalidade é imaginária; o modelo geométrico dele é duvidoso e é precisamente em sua procura que se obstina, de início, a fantasia. (AUMONT, 1993, p. 147).

É, portanto, a relação entre o espaço concreto do espectador e o espaço plástico da imagem, como já citado anteriormente, onde residiria a noção de dispositivo (melhor discutida no segundo capítulo deste trabalho), tendo em vista que cada uma dessas imagens foi produzida para ser localizada e visualizada em determinado espaço físico. Margareth Werthein chama a tenção para o fato de que mesmo os trabalhos renascentistas, na busca por uma representação fiel do espaço físico, também incorporavam em seu esquema espacial maior o corpo do espectador naquele espaço físico em que a imagem se encontra. $\mathrm{O}$ ponto de vista único pelo qual a imagem renascentista é construída, denominado centro de projeção, seria também o ponto pelo qual a imagem deveria ser vista, portanto uma localização especial dentro das catedrais, por exemplo, de onde o observador poderia reconstituir o próprio olhar do artista ao projetar a pintura, o que significaria o reconhecimento da presença de um corpo observador no espaço durante a concepção dessas pinturas, corpo físico concreto em um espaço físico concreto. Vincularia assim espaço virtual da imagem ao espaço físico do espectador, evoca uma consciência da localização. A autora, no entanto, afirma que embora tenha existido essa tentativa de certa incorporação do observador nesse espaço físico, esse mecanismo acabou por distanciar esse observador de seu próprio corpo, por induzir uma dissociação de seu ponto de vista em detrimento de um ponto de vista imposto na construção esquemática daquelas imagens.

O caso do renascimento é só um exemplo de como essa relação entre espaço virtual e espaço físico se apresenta. Essa situação rememora uma questão ainda mais abrangente, que é a da inserção de trabalhos de arte em determinados espaços físicos onde poderão, de certa maneira, exercer suas funções como objeto a ser fruído. Noéle Ramme (2004) se apropria do conceito de instauração de Nelson Goodman para pensar esse processo. Segundo esse pensamento, uma obra de arte o é a todo o instante, desde sua concepção e realização, no entanto, só passaria a funcionar como tal a partir do momento em que é instalada em um espaço (a ativação) e estabelece relações com um mundo existente ao mesmo tempo que muda este último a partir de fatores físicos como enquadramento, iluminação, a relação com outros objetos presentes no mesmo espaço até fatores psicológicos.

Esse processo nos direciona para uma outra questão que é a diferenciação que Yi-Fu Tuan (2001) faz entre espaço e lugar. Até aqui viemos mostrando algumas concepções dessa 
categoria espaço e como existe um esforço de representação disso em um plano bidimensional, que de alguma maneira traria novos significados ao olhar sobre o espaço. Tuan traz a tona o fato de que mesmo no âmbito do espaço físico, da tridimensionalidade, espaço concreto do qual Aumont (1993) fala, existem estratégias de articulação que também são ditadas por determinadas regras e convenções, citando a arquitetura como principal exemplo. Antes de levantarmos a questão arquitetural, no entanto, deixemos claro o que o autor delimita como a diferenciação entre espaço e lugar.

O espaço aqui se trata de uma categoria correspondente muito mais ao plano do fenomenológico de Merleau-Ponty do que ao plano do espaço concreto de Aumont. Desse modo, para Tuan, o espaço seria uma categoria formada por unidades geométricas (área e volume), diretamente experienciado, sem caminhos trilhados e sinalizações, sem padrões fixos, sem significações humanas estabelecidas. Atuaria, portanto, sugerindo o exemplo do autor, como uma folha em branco em que significados podem ser colocados, muito mais como uma condição biológica de sobrevivência para todos os animais, uma necessidade psicológica, social e também um atributo espiritual em alguns casos. O espaço aqui nos parece, portanto, como um paralelo da natureza em sua essência, sem modificações. No entanto, essa noção nos parece um tanto problemática se retomamos a própria concepção de espaço de Merleau-Ponty, pois embora se aproxime de alguma maneira do espaço fenomenológico, essa concepção de Tuan também se distancia pelo fato de que esse elemento seria constituído de um ser desorientado, e isso não pode ser verdade para Merleau-Ponty, já que os elementos da profundidade, altura, largura, grandeza aparente nos tornam seres orientados, na relação com o espaço e todas as grandezas que o constituem. Somos orientados independentemente das construções sociais que perpassam nossa existência, o que mudaria seriam as maneiras de lidar com essa orientação e a devolução disso ao mundo.

Acreditamos que Tuan parta de um pressuposto equivocado ao definir esse espaço, no entanto, o autor apresenta importantes considerações acerca do que viria a ser o lugar. Essa outra categoria seria basicamente o espaço humanizado, um centro de valores estabelecidos, é o momento em que o espaço se tornaria familiar a nós em função de convenções e do tempo experienciado, que é estendido e permite uma proximidade e reconhecimento. É construído para satisfazer necessidades práticas e pode ser exemplificado por meio de significados diversos, entre eles a proeminência visual (a existência de pontos de interesse), a arte, a arquitetura, as cerimônias e os rituais. Seria o mundo organizado por meio da ação humana.

Dentre essas possibilidades de fundação dessa categoria lugar, interessa-nos nesse trabalho a relação entre a arte e arquitetura. Tuan dedica um bom excerto de seus estudos para 
definir a arquitetura como um dos principais elementos que engendram o lugar, por ser na prática um espaço de aprendizagem. A arquitetura clarifica regras e relações sociais, é humanamente projetada, por ensinar é uma chave da compreensão da realidade, requer decisões pragmáticas de orientação tanto na construção quanto na experiência, proporciona o afinamento das noções de dentro e fora, vertical e horizontal, enfim, instrui, pois, é composta por sinalizações, provoca deslocamento. Trouxemos à tona Tuan por acreditar que um lugar específico é importante para nossa pesquisa, a galeria de arte, definindo-a assim como recorte de um conceito espacial mais amplo. A galeria seria um lugar, espaço arquitetônico de aprendizagem em que a ação humana, e artística especificamente, faz surgir uma série de significações. Nesse lugar que chamamos galeria várias de experiências de espacialização serão apresentadas no âmbito da arte contemporânea, como no que se refere às práticas da instalação, nosso objeto de discussão no próximo tópico.

\subsection{ESPAÇOS DE EXIBIÇÃO}

O cubo branco foi um instrumento de transição que tentou descorar o passado e ao mesmo tempo controlar o futuro lançando mão de métodos pretensamente transcendentais de presença e poder. Mas o problema dos princípios transcendentais é que por definição referem-se a outro mundo, não a este. É esse outro mundo, ou o acesso a ele, que o cubo branco representa (...) O sentido definitivo do cubo branco é essa ambição transcendental que elimina a vida, disfarça-se e transforma-se com fins sociais específicos (O’DOHERTY, 2002, p. XXI-XXII).

A questão moderna da galeria como cubo branco se impôs como uma problemática na medida em que se tornara um ambiente de consagração ou legitimação do objeto de arte, e essa é uma discussão que gerou uma série de rejeições a esse lugar momento em que artistas buscaram cada vez mais essa saída para um "mundo real" em que a arte poderia encontrar a “experiência real” e cotidiana. No entanto, esse lugar que permeia o circuito de arte por tanto tempo não encontrou uma efetiva desativação das suas funções, e isso é claro ao verificarmos a continuidade de sua existência como um espaço que ainda abriga a produção contemporânea de arte e que soube estar atento para as modificações e acolher suas nuances e reivindicações.

Queremos, portanto, pensar a análise desse espaço específico e das produções que ele abriga, como um lugar, no sentido anteriormente descrito por Tuan, espaço de construção de significações, que orienta, instrui, ensina, e oferece possibilidades de reflexão, relacionando assim, diretamente a um espaço arquitetônico que se constrói por meio da experiência da arte. Não se trata aqui de estabelecer uma hierarquia em relação a qualquer outro espaço de exibição 
de produção de trabalhos de arte, mas sim da realização de um recorte no que se refere aos locais possíveis que uma produção de arte pode ser instalada para entrar assim em contato com o espectador e propiciar experiências diversas. Essa escolha se tornará mais clara na medida em que analisarmos mais à frente neste trabalho a possibilidade de experiência espaço-temporal modificadora que a galeria historicamente proporcionou no que se refere a uma diferenciação da experiência do vídeo com relação a outros conteúdos audiovisuais, fruídos no espaço privado da televisão ou no espaço da sala de cinema.

Queremos aqui nos afastar da ideia da galeria como cubo branco, espaço intocável, de máxima limpeza, que refuta o toque, onde impera um distanciamento. Nesse sentido, a concepção de galeria poderia se transmutar, portanto, numa outra questão, estamos na verdade falando de espaços arquitetônicos fechados que se permitem emergir como território para a instalação de trabalhos de arte, em nossa pesquisa especificamente das artes visuais e, nesse sentido, um teatro pode também servir a isso, uma cafeteria, um quarto entre outros pode ser transformado num espaço de exibição. Queremos ressaltar aqui a relação do trabalho de arte com o espaço arquitetônico que a abriga, envolve e é modificado por ele. Não é simplesmente um lugar com paredes brancas em que quadros são colocados numa distância curatorialmente estabelecida e segura do observador. Longe disso, queremos falar do momento em que essas convenções foram transformadas e esse lugar passou a agir e ser construído espacialmente como vetor de aprendizagem de uma outra maneira. Sobre a ideia do cubo branco, O’Doherty (2002) ressalta:

\footnotetext{
A aparente neutralidade da parede branca é uma ilusão. Ela representa uma comunidade com ideias e suposições comuns. Artista e público estão, por assim dizer, invisivelmente estatelados em duas dimensões num território branco. A criação do cubo branco impoluto, ubíquo, é um dos êxitos do modernismo - criação comercial, estética e tecnológica. Num strip-tease insólito, a arte lá dentro se desnuda cada vez mais, até apresentar produtos finais formais e porções de realidade externa - tornando o recinto da galeria uma “colagem”. (O’DOHERTY, 2002, pág. 90).
}

Brian O’Doherty (1999) cita alguns exemplos de práticas que demonstraram esse esgotamento das convenções da galeria, como a planificação cubista da superfície a partir das colagens e as pinturas impressionistas de Monet (1840-1926), que ao apresentar temas que se distanciam da tentativa de representação de profundidade causam uma tensão e reforçam suas bordas (aqui um claro diálogo com as concepções de Jacques Aumont e Nöel Burch), burlando a ideia do quadro como objeto auto-suficiente no espaço, trazendo um diálogo com o fora do quadro e por isso tensionando também as próprias regras do cubo branco, já que essas imagens já não se prendem aos espaços e distâncias definidas nas paredes. Essas manifestações irão se 
expandir até o momento em que o personagem "observador" passa a ter um lugar de "participador", passa a ser incluído nesse espaço de maneira determinante para a construção de trabalhos contemporâneos, na medida em que só o movimento deste no entorno espaçotemporal poderá fazê-lo refletir sobre este lugar, e aqui se encontra para O’Doherty, a segunda grande virada na modificação do espaço de arte da galeria.

Não dizemos, com isso, que esse movimento não acontecia quando da época das exposições impressionistas, para continuar no exemplo citado, mas que ele passa a se dar em uma outra ordem a partir de determinado contexto histórico que entendemos usualmente como arte contemporânea. Outro fator importante para o autor é o que ele chama de invenção do contexto, e as relações entre continente e conteúdo, o desenvolvimento da ideia da galeria como unidade a ser manipulada, projetos que só existem para esse recinto, ou que ao deixarem de ser exibidos tomam outra forma e só existem potencialmente por meio de registros, planos, dossiês, esquemas de montagem. Sobre todos esses fatores e contexto, O’Doherty, mais uma vez declara:

\begin{abstract}
Dos anos 20 aos 70, a galeria tem uma história tão diversa quanto a arte que ela expõe. $\mathrm{Na}$ própria arte, uma trindade de mudanças produziu um novo Deus. O pedestal desmoronou, deixando o espectador mergulhado num espaço de parede a parede. Assim que a moldura sumiu, o espaço se espraiou pela parede, gerando turbulências nos cantos. A colagem desprendeu-se do quadro e se acomodou no chão com a naturalidade de um pedinte. O novo Deus, espaço amplo, homogêneo, fluiu facilmente por todos os lados da galeria. Todos os empecilhos foram removidos, exceto a "arte". (O'DOHERTY, 2002, p. 101).
\end{abstract}

Entre os fatores que proporcionaram essa expansão, e surgido também no final desse contexto, uma prática específica na arte contemporânea é de nosso interesse, as instalações. Segundo Claire Bishop (2005) o termo surge no território da arte nos anos 1960 e traz consigo uma problemática de definição. Para a autora deve-se ter em mente a diferença entre a installation art, instalação como prática artística, e a instalação de obras de arte, arranjo de uma diversidade de trabalhos em determinado espaço, que se relaciona muito mais a uma prática curatorial, e que enfatiza as individualidades em detrimento do todo. De outra maneira, a arte da instalação enfatizará a totalidade do espaço e os elementos que os constituem. A chave para a compreensão da arte da instalação seria, portanto, a insistência na necessidade da presença do observador/participador naquele espaço, em que o tocar, o cheirar, o ver, o ouvir pudessem ser trabalhados em diálogo, o que o diferiria das outras modalidades artísticas mais tradicionais como a pintura, escultura, desenho. Em vez de representar elementos como luz, textura, profundidade, a arte da instalação os apresenta diretamente para nossa experiência. Segundo a 
autora esse tipo de prática surge com dois objetivos principais que seriam a ativação e o descentramento do público. Desse modo esses trabalhos poderiam ser caracterizados, ou categorizados, de acordo com a experiência estruturada a ser oferecida.

Além de uma imersão física, esses trabalhos atuariam na direção de uma absorção psicológica, fundando para a autora um cenário de sonho, que tem relação direta com as problematizações em voga na época acerca disso na teoria de Sigmund Freud ${ }^{6}$ (1856-1939), propiciando reações conscientes e inconscientes desse espectador na relação com suas atuações no mundo fora da galeria e o seu encontro com o trabalho instalativo, servindo como um modelo de mundo, trazendo a tona fantasias, memórias individuais, associações culturais para aquele espaço. É esse processo que para a autora levaria a um descentramento do sujeito na sua relação com o espaço.

A segunda estrutura apresentada por essas instalações é o que se refere diretamente à influência dos pensamentos de Merleau-Ponty (já apresentados anteriormente) e a existência de um espaço fenomenológico que não pode ser desprendido do corpo que percebe. Portanto, trabalhar esse espaço deve ser por tabela trabalhar o corpo físico que ali se encontra, pois só posso chegar a compreensão dessa localização a partir desse acoplamento entre corpo e espaço, do qual faço parte. Nesse sentido, essa outra estrutura buscou uma ativação desse observador pelo movimento, tornando-o elemento desse espaço a ser circundado.

Claire Bishop pontua a necessidade de retornar ao movimento Minimalista para compreender como essa segunda estrutura se apresenta. Nesse âmbito o Minimalismo estaria situado entre o processo de expansão espacial da escultura e o surgimento da instalação como a conhecemos, trabalhando com estruturas geométricas simples, o que a tornou, para a crítica de arte daquela época, uma prática anti-expressiva, não humanizada e mesmo tediosa.

De outra maneira, Claire Bishop declara que o movimento de andar por entre essas esculturas fortaleceria nossa consciência da relação desta com o espaço instalado, voltando nossas atenções também para elementos como altura, largura e iluminação da própria galeria. No entanto, para os próprios artistas do Minimalismo, como Robert Morris (1966), suas práticas não se relacionavam com esse conceito de instalação, e para o artista o fato de (...) o espaço da sala ter tomado importância não significa que uma situação ambiental fosse estabelecida (MORRIS, 1966, p. 223) ", o que veríamos na sala se exibição seria uma série de esculturas que deveriam sim ser vistas separadamente, independente do conjunto. Por outro lado, Michael Fried (2002) sugere que esses trabalhos estão muito mais relacionados a uma teatralidade do

${ }^{6}$ Médico e neurologista criador da psicanálise. 
que propriamente à escultura, pois compartilham o mesmo espaço e tempo que o público, mais do que transportam-no a outro mundo, e são marcados pelo elemento da duração, o tempo percorrido. Fica claro nas declarações de Fried, as características compartilhadas entre o Minimalismo e o que se constituiu como a arte da instalação, conforme descrito abaixo:

\begin{abstract}
A produção recente de boa qualidade extrai relações do trabalho e faz delas uma função do espaço, da luz, e do campo de visão do espectador. O objeto é tão somente um dos termos dessa nova estética. Essa é de certo modo mais reflexiva, porque a consciência que alguém tem de si mesmo existindo no mesmo espaço que o trabalho é mais forte do que em trabalhos anteriores, com suas muitas relações internas. $\mathrm{O}$ espectador torna-se mais consciente do que antes do fato de estar ele mesmo estabelecendo relações, uma vez que apreende o objeto a partir de posições variadas e sob condições variáveis de luz e contextualização espacial. (FRIED, 2002, p. 135).
\end{abstract}

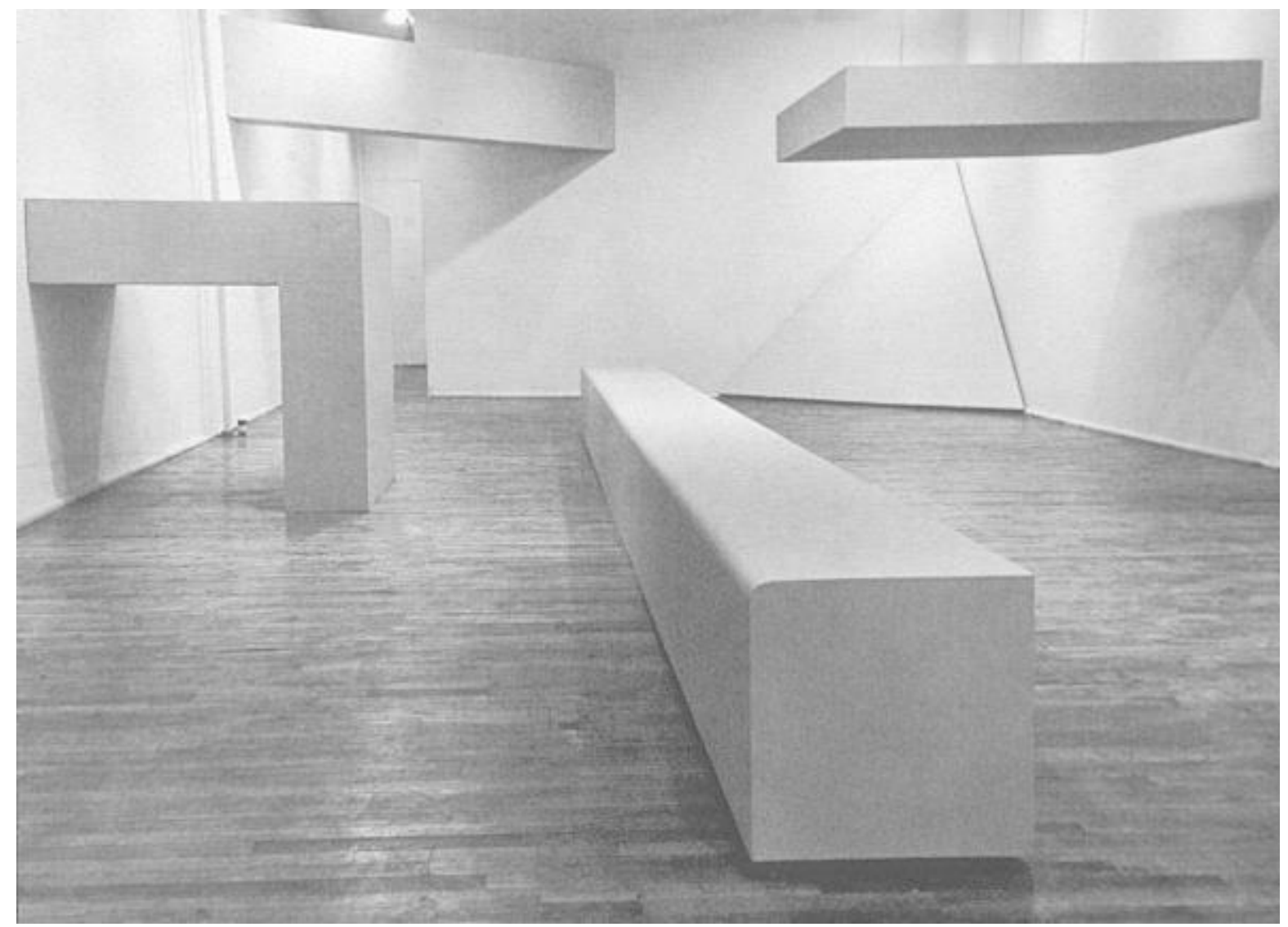

Ilustração 01: Instalação de Robert Morris, datada de 1964, na Green Gallery, em Nova York (EUA).

Fonte: www.studyblue.com

O alcance do trabalho dos minimalistas não poderia, no entanto, se ater aos objetivos prévios de seus criadores, e a questão do diálogo com o espaço circundante levou de certa maneira à formação de um ambiente a ser experienciado dentro das galerias. O minimalismo é 
obviamente apenas um dos precedentes dessa prática da instalação e, como já citado anteriormente, desde o renascimento, por exemplo, essa preocupação com a relação entre espaço plástico e espaço concreto já era estabelecida. Podemos citar outras vertentes como precedentes ou desenvolvimentos posteriores da instalação, como o construtivismo russo, a exposição surrealista de 1924, a Mezrbau de Kurt Schwitters, os trabalhos de El Lissitzky, o Monumento à Terceira Internacional concebido apenas em maquetes por Vladimir Tatlin, as vivências dos ambientes de Hélio Oiticica, características como a utilização de espaços vazios onde apenas a luz e a escuridão são apresentadas, os trabalhos de videovigilância, a Land Art, os happenings. No entanto, não temos o objetivo de construir aqui uma história da arte da instalação.

Essas práticas são, portanto, responsáveis pelo encadeamento das discussões que Rosalind Krauss (2009) levantará no final da década de 1970 acerca da escultura no campo ampliado. Segundo a autora, o conceito de escultura sofreu neste período histórico uma ampliação ao ponto de se caracterizar simplesmente por tudo aquilo que, tridimensionalmente falando, seria não-paisagem e não-arquitetura. Essas oposições devem, no entanto, ser relativizadas, já que a não-arquitetura, por exemplo, seria só um outro modo de chamar a paisagem, e, portanto, uma obscuridade se coloca na própria concepção de escultura. Segundo Krauss, alguns precedentes como a perda do pedestal, o abandono da lógica do monumento em sua existência específica para a arquitetura muitas vezes com fins didáticos, contribuíram para o surgimento desse estado negativo da escultura, retirando-a da estabilidade do objetivo de existir em um lugar fixo ou de abrigo. A autora pontua como o surgimento do novo é quase sempre melhor entendido como uma espécie de desenvolvimento de práticas já existentes na história, o que a leva a propor, partindo da análise das transformações da escultura, essa concepção do campo ampliado, e sobre isso discorre:

\footnotetext{
(...) no pós-modernismo, a práxis não é definida em relação a um determinado meio de expressão - escultura - mais sim em relação a operações lógicas dentro de um conjunto de termos culturais para o qual vários meios - fotografia, livros, linhas em parede, espelhos ou escultura propriamente dita - possam ser usados. (KRAUSS, 2009, p. 136).
}

Dentro desse campo de ampliação a instalação é sem sombra de dúvidas um dos maiores exemplos, e a própria noção de campo ampliado ratifica como essa prática se dá justamente na operação de arranjo de materialidades diversas em um mesmo espaço e que não podem ser pensadas de maneira isolada de seu conjunto, encarna o próprio espírito desse período que Krauss chama pós-modernismo, embora ainda seja inevitavelmente tratada como categoria de 
produção dentro do circuito de arte, e não como uma atividade operatória mais ampla que perpassa a arte em suas diversas linguagens. Queremos apenas pontuar como essa prática levou ao reconhecimento do espaço da galeria como um fator possível de diálogo para a construção de trabalhos e como esses ambientes construídos articularam de uma outra maneira a presença do espectador. De maneira resumida, essa instalação proporcionou um trabalho de potencialização do corpo no espaço, aumentou a consciência das especificidades físicas da galeria, ao criar ambientes imbuiu essas propostas de um caráter de fruição coletiva, de espaço compartilhado, novos modos de vivenciar um trabalho de arte, por sua natureza ser também nova, saindo do foco exibição do objeto para a experiência processual. Além disso, se queremos falar desses espaços instalativos, ficou claro que, embora possamos de certa maneira distinguir pelo todo, não podemos pensá-los fora da relação com outras linguagens das artes plásticas, e a prática da escultura e sua expansão torna-se então um elemento fundamental.

Como já apontado por Claire Bishop, esses trabalhos tem muito mais relação com estudos de Merleau-Ponty ou Henri Bergson, e essas situações de experiência proporcionadas dependerão das estruturas oferecidas ao observador. A instalação é para nós uma prática que pode potencializar aquilo que Merleau-Ponty chama abandono, o movimento no espaço, e assim uma reflexão surge. É nesse espaço como lugar que aquelas noções de espaço espacializado e espaço espacializante se encontram para o surgimento dessa operação que chamamos espacialização.

\section{3 - ESPACIALIZAÇÃO}

Até este ponto do trabalho realizamos um levantamento de alguns aspectos que consideramos importantes para a discussão dessa categoria espaço no território da arte. Ao trazermos para essa discussão filósofos como Maurice Merleau-Ponty e Henri Bergson quisemos de alguma maneira aproximar uma análise da experiência do espaço dentro dessa prática artística a qual conhecemos como instalação e que foi apresentada no tópico anterior. Em outro sentido, a partir de Jacques Aumont e Nöel Burch, quisemos verificar como essas questões de espacialidade se apresentam na categoria imagem como representação desse mesmo espaço físico do qual as instalações se preocuparão em problematizar. Um entrelaçamento surge, no entanto, no momento que consideramos essa imagem como um objeto físico no mundo. 
O espaço do qual estamos falando, portanto, refere-se a duas dimensões. Por um lado, o espaço físico, a tridimensionalidade e a experiência do tempo. Nesse espaço indicamos a busca pela expansão de uma experiência do espectador, conforme apresentado a partir das instalações, uma busca arquitetônica de composição e reestruturação. Falamos nesse momento, portanto, do espaço como lugar, nos termos já definidos por Tuan. No outro lado, o espaço da imagem, em que os artistas buscaram representar o espaço físico criando determinadas leis, como já exposto anteriormente, bem como desconstruindo estas a partir do que Aumont (2005) chama deformação.

Assim, neste trabalho não temos o objetivo de tratar especificamente da instalação como categoria artística, mas reconhecemos ser nesse âmbito que algumas das discussões que levantaremos nos próximos capítulos se encontram. De acordo com o que explanamos acerca dessa categoria, a partir dos estudos de Claire Bishop, haveria na instalação uma necessidade da criação de um ambiente total a ser percorrido pelo observador, ele está imerso em um espaço construído. Essa, no entanto, seria apenas uma das possibilidades de espacialização que a nossa outra variável de estudo, o vídeo, nos apresenta.

O que seria então essa espacialização? Utilizamos neste trabalho esse termo para designar as operações de arranjo e composição dos elementos a partir de um pensamento espacial. Portanto, todos os trabalhos a serem analisados nesses estudo partem da existência de uma imagem técnica ${ }^{7}$, o vídeo, seu processo de composição interna, dentro do quadro, e as extensões de significação da narrativa do vídeo para o espaço físico de exibição, na relação com outras imagens fixas, objetos, esculturas, pinturas, o próprio aparelho transmissor, a construção de ambientes imersivos, e até performances audiovisuais em que, embora muitas vezes também imersivas, o tempo apresentado se difere das instalações.

O que chamamos espacialização se define, portanto, como uma operação que se localiza enquanto prática compositiva e compreende essas manifestações às quais nos referimos anteriormente. Está, portanto, diretamente ligada aos conceitos compositivos já apresentados: a questão do centramento e descentramento, o enquadramento e desenquadramento, as bordas e os espaços imaginários, luz, janelas, cor, saturação, todos podem ser objeto para compor enquanto espacialização, e a questão da deformação deve ser levada em consideração na relação com esses elementos, que como veremos mais a frente podem servir a análise dos trabalhos apresentados no campo bidimensional ou tridimensional. De maneira geral, a composição seria a prática de organização dos elementos de maneira mais geral, na medida em que esses não são

\footnotetext{
7“(...) imagem produzida por aparelho” (FLUSSER, 2009, p. 78).
} 
necessariamente sempre elementos espaciais. A espacialização seria como um efeito ou elemento da composição, porque se refere a uma operação de problematização da estrutura do espaço e no espaço. Entre um extremo da composição bidimensional dentro do quadro e o outro do espaço físico imersivo e estruturado por uma série de objetos, uma variedade de práticas de espacialização pode existir, numa relação direta com a maneira como a imagem se estenderá nesse espaço.

Quando sai do quadro, uma das características da espacialização seria, portanto, a agregação de conteúdos que são materialmente diferentes da imagem, mas complementam sua narrativa, inclui uma extensão de significado por meio do agrupamento junto à imagem. É o que acontece por exemplo, em algumas videoinstalações, para refinar o estudo e ir diretamente ao nosso objeto de pesquisa, o vídeo. Essa imagem pode se estender nesse percurso em dimensões variáveis, bem como esses outros objetos com os quais ela irá se relacionar no espaço físico em que se encontra também possuem dimensões variáveis. No entanto, no momento em que essas dimensões ultrapassam o tamanho físico de nosso corpo e entramos em uma estrutura de imersão a partir de todos esses objetos ou pelo tamanho deles (inclusive a imagem), uma situação de instalação se instaura. Indicaremos no trabalho esse percurso que vai da espacialização no quadro (imagem), agrega objetos em dimensões variáveis (extensão) no mesmo recinto que o vídeo, e por fim ocupa espaços inteiros (ambiente), este último podendo compreender as duas situações anteriores.

Todas essas problematizações serão melhor desenvolvidas e exemplificadas a partir da apresentação dos trabalhos artísticos que se seguirão nos próximos capítulos. Pra finalizar as discussões espaciais mais amplas que aqui apresentamos gostaríamos de salientar que no percurso de espacialização da imagem o corpo torna-se o vetor de comparação no nível da escala com o tamanho da imagem, e permite assim a definição de que nível de espacialização estamos falando, se dentro da imagem ou se nos níveis da extensão entre vídeo e objeto ou vídeo e ambiente. Aqui, de maneira mais pragmática e como metodologia para pensar essas relações, acabamos tomando o corpo no sentido de Henri Bergson, um centro de comparação física com as outras imagens que o rodeiam, mas com a ressalva de acreditar, assim como Merleau-Ponty, que esse espaço tem o mesmo potencial modificador do corpo.

Como já explicitado no título deste trabalho, iremos nos ater aos processos que concernem à espacialização da imagem do vídeo (do quadro ao espaço físico). Mas do que estamos falando quando se trata de vídeo? Quais as características desse tipo de imagem técnica e porque a questão do espaço, a qual dedicamos um capítulo inteiro deste trabalho, deve ser tomada como fundamental para sua compreensão? São algumas das questões que 
problematizaremos nos próximos dois capítulos. No capítulo que se segue procuraremos levantar algumas questões para pensar as características dessa mídia vídeo e sua configuração como videoarte na relação com três variáveis: a televisão, o cinema e o computador. 
CAPÍTULO 02 VÍDEO 
Como já especificado em nossa introdução, buscamos neste trabalho elaborar alguns questionamentos acerca de dois elementos, o vídeo e o espaço, de modo a elencar algumas das maneiras com as quais esse vídeo se espacializa. No primeiro capítulo nos debruçamos sobre uma dessas variáveis, o espaço, levantando questões que perpassam a Filosofia e a Teoria da Arte pra delimitar como compreendemos essa operação que chamamos espacialização. Nesse momento queremos então realizar um esforço de delimitação de algumas características desse segunda elemento, o vídeo.

Abordaremos as discussões acerca das mudanças que o desenvolvimento da tecnologia de vídeo proporcionou na cultura das imagens em movimento. Nesse sentido buscaremos, em um primeiro momento, deflagrar como a iminência de algumas características técnicas de gravação, armazenamento e edição de vídeo proporcionaram a edificação de novas ações poéticas que culminaram num caminho de construção da prática da videoarte. Esse caminho e o surgimento de novos formatos foram também responsáveis pelo surgimento de novas possibilidades para uma expansão do vídeo no que se refere aos modos de espacialização dentro da própria imagem, bem como com relação ao espaço físico em que essa imagem, enquanto elemento também físico, está instalada. O aparecimento do videotape, e a possibilidade de registro das ações para o vídeo, o crescimento do processo de edição dessa mídia, o desenvolvimento dos projetores digitais, deram ao vídeo um caráter de expansão espacial. $\mathrm{O}$ vídeo segue um percurso em que cada trabalho constrói seu próprio espaço de exibição a partir de uma composição única e, muitas vezes, não repetível, já que são exibidas em espaços (galerias e museus) diferentes.

Mas do que então se trata esse vídeo do qual queremos falar? Vários autores já exploraram as características dessa mídia: Arlindo Machado, Chris Meigh-Andrews, Christine Mello, Michael Rush, Philippe Dubois, Sean Cubitt, Raymond Bellour, foram alguns aos quais nos debruçamos para tentar buscar em suas teorias uma definição. Uma abordagem parece pertinente a todos esses autores, o fato de o vídeo atuar como uma mídia de atravessamento entre outras mídias e, portanto, a dificuldade de delimitá-lo hoje como um elemento de especificidade, conforme declara Sean Cubitt (1993):

O vídeo está, portanto, no cerne do crescimento das redes de interconexão entre as mídias anteriormente separadas. No entanto, não pretendo fazer nenhuma reivindicação pelo meio, na verdade o oposto. Não importa como uma revista, por exemplo, é produzida, nós a consumimos mais ou menos da mesma maneira. Um filme que utiliza efeitos especiais ou efeitos computacionais ainda é um filme se nós o consumimos na sala de cinema. (...) Mas todas essas formas culturais compartilham, potencialmente se não verdadeiramente, outra existência como informação eletrônica, produzidas para serem mostradas em uma tela de video ou por meio de projeção de 
vídeo. No cerne desse argumento existe uma sensação de que o vídeo não é nem um meio autônomo, livre de qualquer relação com outras formas de comunicação, e nem inteiramente dependente de nenhuma delas. (CUBITT, 1993, p. XV, tradução nossa).

Essa característica de atravessamento a qual Sean Cubitt se refere na citação acima é claramente deflagrada pelos estudos de Raymond Bellour (1997) quando apresenta o conceito de entre-imagens. Para o autor a força do vídeo no campo do audiovisual é a de um operador de passagens, uma mídia com a capacidade de transformar imagens umas nas outras, desde as que o precederam (pintura, fotografia e cinema) até as produzidas por ele mesmo, um integrador de mídias. A análise de Bellour parece, no entanto, para nós, considerar o vídeo como uma passagem que de certa maneira salvaria o cinema de uma crise eminente, ao ampliar a entrada da imagem cinematográfica no espaço da galeria. Aos trabalhos produzidos tanto em película quanto em video e que encontrariam nos espaços de museus e galerias uma forma de sobrevivência mais experimental o autor chama “outro cinema". Embora apresente importantes e plausíveis considerações acerca dessa relação cinema, videoarte e televisão (veremos algumas mais a frente nesse capítulo) Bellour parece minimizar as práticas de videoarte a elementos integrantes de uma expansão do cinema. Erika Balsom (2013) comenta como Bellour mantém uma rígida separação entre esses dois cinemas, localizando as práticas de vídeo ancoradas ao âmbito deste "outro cinema". As passagens a que Bellour se refere são importantes diagnósticos da condição contemporânea das imagens em movimento, mas o fato do autor acreditar que esse outro cinema deveria se preocupar em recuperar características estéticas e técnicas de um cinema já existente para transportá-los para a galeria insere no seu pensamento a perspectiva de inclusão do vídeo como mero meio para o alcance desse objetivo. Essa identidade do video estaria, portanto, numa relação quase de escavação e retomada do cinema.

Essas questões, que Arlindo Machado (2007) coloca no âmbito de uma condição pósmidiática do vídeo, parecerem reverberar nas análises de uma série de autores, inclusive os citados acima. Um deles é Phillipe Dubois (2004), que em seu livro Cinema, Video, Godard deixa claro que se trata de um estudo das relações entre vídeo e cinema, de onde poderíamos abordar uma das facetas do vídeo, já que seria impossível chegar a uma especificidade dessa mídia. O autor acredita na sua natureza de movimento do vídeo, e desse confronto surge o principal conceito que Dubois elaborará, o do estado-vídeo. O vídeo nesse sentido é para o autor, não um objeto, mas um estado. Um estado de ser e de pensar as imagens contemporâneas como um todo, e especialmente as do cinema, conforme procura demonstrar a partir das inserções dessa mídia nas produções cinematográficas de Jean-Luc-Godard. Dubois parece também conferir ao vídeo uma fragilidade em sua relação com o cinema, dotado de um 
imaginário cinematográfico que o constitui. Por outro lado, também confere ao vídeo uma responsabilidade de exposição do cinema nas galerias de arte. Esse movimento de compreensão do vídeo reside, portanto, entre sua característica de apropriação da linguagem cinematográfica e, ao mesmo tempo, como vetor de surgimento disso que chamamos "cinema de exposição". A questão do estado-vídeo é pertinente a nós desde que não vista como uma condição final do vídeo, que esse não seja tomado simplesmente como veículo de outras mídias, mas que estejamos atentos para suas especificidades (embora impossíveis de serem capturadas segundo Dubois).

Essa situação é encontrada também em alguns escritos de Arlindo Machado (1988), quando confere ao surgimento do vídeo uma abordagem parecida, considerando que o que viríamos a ver em um futuro (futuro esse o qual já vivemos já que esses escritos datam da década de 1980) seria um cinema eletrônico, transformado pelas possibilidades técnicas do advento do vídeo. Muitas das discussões postas por Arlindo Machado já foram revistas e redirecionadas, principalmente no que concerne às questões referentes às tecnologias do vídeo. Não faz mais sentido, por exemplo, tomar o vídeo como aquela imagem de baixa definição, enclausurada no monitor de TV, e mesmo aquelas distinções entre a tela pequena do vídeo e a tela grande do cinema, já que ambas hoje compartilham dessas dimensões. Talvez uma questão que ainda deva ser levantada é a referente ao tempo de fruição da sala de cinema e das experiências contemporâneas com o vídeo.

No entanto, mesmo em seus estudos do final da década de 1990, Machado (1997) insiste em pensar o vídeo dentro de uma espécie de conceito ampliado de cinema, apropriando-se da etimologia da palavra (kínema-ématos + gráphein, “escrita do movimento”) para incluí-lo num âmbito de expansão dessa linguagem cinematográfica. Obviamente as semelhanças, apropriações e devoluções são claras nessa relação cinema e vídeo, mas aqui esperamos encontrar uma força própria do vídeo que surgiu e tem também uma história autônoma à do cinema e que nos parece estar muito mais ancorado e ter encontrado possibilidades de desenvolvimento de linguagem no universo das artes plásticas, onde se configurou também por outros elementos, como o conteúdo televisivo e as imagens computacionais.

Essa abordagem que pensa a utilização do vídeo nas galerias como expansão do cinema torna-se para nós problemática. Tal proposta iria de encontro ao que o próprio Arlindo Machado questiona quando fala que a postura de certa maneira parasitária do vídeo nessa relação com outras mídias, como mero veículo do cinema ou televisão, deve ser evitada. Machado aponta para como a videoarte se mostrou o campo por excelência de negação desse processo, logrando para o vídeo uma perspectiva de linguagem própria. Se retomarmos os primeiros experimentos 
do vídeo, por exemplo, tanto em âmbito nacional quanto internacional, veremos claramente como esses artistas advinham muito mais da experimentação nas artes plásticas ou da relação com a televisão.

Na mesma linha Christine Mello (2008) vai abordar o vídeo a partir de uma leitura interdisciplinar a qual denomina extremidades. Para a autora o vídeo opera transformações das mídias, citando o processo de desconstrução da televisão na década de 1970 e a desconstrução do cinema pelo advento do vídeo digital a partir da década de 1990. Além disso o vídeo se contaminaria com a arte contemporânea nas práticas de videoinstalação, VJ, no embate do corpo com a câmera. Mello deixa claro que sua leitura preza não por uma autonomia de linguagem do vídeo, mas como procedimento de interligação, valorizando seu caráter de interface, algo como o estado-vídeo de que Dubois fala. As práticas contemporâneas de utilização do vídeo seriam, portanto, de uma desconstrução consciente de sua própria linguagem para o aparecimento de suas relações com outras linguagens, abordagem essa que pode para nós conferir a essa mídia aquele estado parasitário que Arlindo Machado (1988) aborda.

Desse modo, ao falar acerca da videoarte, Michael Rush (2006) parece conferir a esta uma identidade muito mais própria e considerar os mais recentes avanços tecnológicos do vídeo. Para além disso, Rush centra seus estudos num limiar muito mais próximo ao da arte contemporânea, citando os eventos fluxus, as performances, a arte conceitual, o minimalismo como marcos para o desenvolvimento da videoarte. Essa identidade da videoarte surge, portanto, de todas essas relações entre os movimentos das artes plásticas, o enfrentamento com a televisão e o cinema e atualmente com as modificações possibilitadas pelo computador. $\mathrm{O}$ autor pontua três principais características que configuram a prática da videoarte: 1) a relação com o corpo nas performances para o vídeo, principalmente em seus primeiros anos, relacionado com ações conceituais; 2) as possibilidades de expansão de narrativas de maneira linear ou não-linear, explorando questões de identidade, sexualidade, autobiografia, fantasias; 3) a hibridização de tecnologias no âmbito das videoinstalações, instalações interativas e a realidade virtual. As passagens aqui também são claras, no entanto, ao apresentar essas características em seus estudos Rush nos parece muito mais alinhado a uma busca por definição do vídeo como linguagem que possui uma autonomia frente a esses movimentos que também o atravessam.

Essa força de atravessamento do vídeo é uma característica essencial de sua natureza contemporânea, mas em qual momento, em qual espaço, o vídeo deixa de ser mero veículo de outras mídias, interface de outras linguagens para edificar uma linguagem e história próprias? Portanto, propomos pensar o que há de específico dessa linguagem sem perder de vista essa 
questão das convergências de mídias que é proposta por esses autores. Convergência, no entanto, parece uma palavra difícil de adotar, e concordamos com Erika Balsom quando diz que:

\footnotetext{
Mais do que comprar a ideia de que toda mídia se converterá em uma questão digital homogênea, é necessário hoje interrogar as maneiras em que os limites entre mídias são articulados e borrados, para vermos o par convergência/especificidade como existindo em uma tensão dialética um com a outra e que permite um novo pensamento sobre a historização de ontologias mais do que dissoluções, ou mesmo desaparecimento de uma dada mídia. (BALSOM, 2013, p. 17, tradução nossa).
}

O nosso esforço é, portanto, muito mais alinhado às questões levantadas por Balsom, na busca por uma análise não necessariamente dessas passagens, do vídeo como interface, mas de certos elementos de especificidade do vídeo que, de certa maneira surgem, ou reverberam nessas outras mídias. Evitamos a localização do vídeo como elemento de um cinema expandido, por exemplo, por acreditar no seu protagonismo nessa relação com as outras mídias. Não estamos negando essa relação, e muito menos as reflexões proporcionadas pelos autores citados (que atravessarão também todo nosso texto na análise de trabalhos de videoarte), muito pelo contrário, propomos apenas visualizá-las por uma perspectiva em que o vídeo se torne o elemento fundante de sua própria história, entendendo seus mecanismos próprios de linguagem e os espaços em que ele obteve maior êxito em seu desenvolvimento, como uma prática que se difere de outras no campo do audiovisual mas que delas se apropria e por elas se transforma. Acreditamos encontrar nas exibições do vídeo em museus e galerias um lugar propício para o encontro dessas características e, por isso, nos ateremos a esse contexto. Queremos delimitar, portanto, que nossa análise se focará nisso que chamamos videoarte, especificamente nas suas dimensões espaciais.

Procuramos identificar e especificar alguns dos principais formatos de vídeo surgidos na história, desde os formatos analógicos aos digitais. Esse mapeamento nos permitiu encontrar nesse desenvolvimento tecnológico os pressupostos técnicos que embasam as especificidades dessa mídia no que se refere ao seu potencial de espacialização. Como já dito, o vídeo tornouse, tecnicamente falando, a mídia por excelência de compartilhamento de conteúdo de linguagens já pré-estabelecidas. A televisão surge com o vídeo em transmissão direta e continua sua empreitada de transmissão com o videotape e posteriormente com os formatos digitais. $\mathrm{O}$ cinema hoje em dia, embora ainda produzido em película, tem essa mídia transformada tecnicamente para vídeo para possibilitar a projeção digital nas novas configurações de salas de exibição com projeção digital, bem como há algum tempo já se apresenta pelo vídeo a partir do 
advento da distribuição doméstica das produções cinematográficas em VHS, DVD, Blu-ray, ou mesmo já é gravado por meio de informação digital em vídeo. Claro que quando falamos de cinema neste momento nos referimos à sua faceta mais comercial, aquele produzido para ser exibido nas salas mais tradicionais onde uma forma cinema se impõe, com a consciência da existência de uma série de experiências transgressoras dentro dessa própria linguagem, como indicaremos mais à frente. Introduziremos então uma discussão acerca do vídeo para além de uma ferramenta tecnológica de gravação e transmissão de outras linguagens como o cinema e a televisão. Para falar sobre isso é, no entanto, importante levantar que tipo de relações estéticas foram estabelecidas historicamente entre essas linguagens, e como a introdução das tecnologias digitais modificou essas relações.

Obviamente, uma série de diálogos podem ser extraídos da reflexão entre esses meios e a prática do vídeo instalado nas galerias, no entanto, nosso objetivo nesse capítulo é o de estabelecer uma ligação entre certas técnicas, características ou movimentos desses meios que de alguma maneira falem da relação que nos interessa nesse estudo, as questões de espacialidade na videoarte. Portanto, queremos deixar claro que não falamos aqui de uma totalidade dessas relações, o que nos levaria para outro caminho de discussão. Realizaremos apontamentos de como problematizações espaciais aparecem nas produções contemporâneas de videoarte e de que maneira isso reflete algumas características de práticas que antecederam seu advento, foram contemporâneas ao seu surgimento ou mesmo como as questões do digital tem modificado essas relações. Apontamos ainda que manteremos um foco em como essas imagens técnicas (cinema, televisão, computador) se relacionam com o vídeo, com a consciência de que podemos falar também de como as artes plásticas influenciaram a história da videoarte. Essas questões, já pontuadas de alguma maneira a partir do minimalismo em nosso primeiro capítulo serão melhor exploradas no modo como práticas como a pintura, a escultura, os objetos, entre outros, aparecerão inevitavelmente quando discutirmos no terceiro capítulo os modos de espacialização do vídeo.

Procuraremos argumentar como a exibição em museus e galerias se mostrou o lugar propício para o desenvolvimento de uma linguagem específica do vídeo, culminando na existência dessas produções que chamamos videoarte, principalmente a partir de um elemento essencial, a possibilidade de uma interação diferenciada que esses espaços proporcionaram, indicando. Parte disso se deve ao fato de que o circuito de arte em sua maioria oferece espaços muito mais predispostos a uma experimentação artística sem amarras unicamente mercadológicas, como no circuito mainstream de um tipo de cinema e o aspecto broadcast da televisão, expandindo assim o raio de atuação dos profissionais que ali aparecem. A galeria 
tornou-se um celeiro de experimentações para importantes artistas do vídeo desenvolverem e exibirem seus trabalhos que não cabiam bem ao modelo de exibição televisiva e nem da sala de cinema mais tradicional. Atentamos, no entanto, para problematizar os modos de interação que esses espaços proporcionam, e como essa interação pode ser também uma outra maneira de estabelecer um poder diferenciado sobre as tomadas de decisão dos espectadores nesses espaços. Tomamos como principal referência para a reconstrução histórica das práticas com o vídeo na arte contemporânea a recente edição do livro A History of Video Art (2014), de Chris Meigh-Andrews, um apanhado abrangente de como o vídeo se portou ao longo dos anos frente ao sistema de arte e como essas outras mídias como o cinema e a televisão desencadearam a formação de uma identidade para o vídeo na galeria de arte.

\subsection{LINGUAGENS E IMAGENS EM CONTAMINAÇÃO: A VIDEOARTE}

Partimos da premissa de que o caráter poético de um trabalho artístico não pode estar desvencilhado de seus mecanismos técnicos, compreendendo este último, portanto, como um caminho necessário para a construção mais ampla de uma poética artística, assim como declara Arlindo Machado (1997):

\footnotetext{
Quando se fala de imagens é impossível pensar a estética independente da intervenção da técnica (...) Nenhuma leitura dos objetos visuais ou audiovisuais recentes ou antigos pode ser completa se não se considerar relevantes, em termos de resultados, a 'lógica' intrínseca do material e das ferramentas de trabalho, bem como os procedimentos técnicos que dão forma ao produto final (MACHADO, 1997, p. 223).
}

Ao falar de uma lógica intrínseca do material, Arlindo Machado nos direciona para a importância de compreender como o funcionamento técnico de determinada mídia diz muito de sua história e desenvolvimento dentro de um contexto cultural. No que se refere ao vídeo, uma importante questão dá rumo às nossas pesquisas, em diálogo com Wolfgang Ernst (2002): ao falarmos de vídeo, devemos nos prender à câmera, ao formato em que a mídia será gravada, ou devemos estar atentos à forma como a mídia é exposta, exibida ao público? Essa questão dialoga também com o que Almir Almas (2013) chama de linguagem de produção e linguagem de uso, definidas pelo autor da seguinte maneira:

A linguagem de uso é simplesmente a maneira de usufruir do meio, de tirar dele o melhor proveito, de aprender a interagir com a interface. Já a linguagem de produção significa aprender a produzir para o meio, a usá-lo como veículo de distribuição de 
informação, mensagem, conhecimento e também aprender a dominá-lo tecnicamente (ALMAS, 2013, p. 64).

Desse modo, vemos como o vídeo pode ser tratado por dois ângulos, o dos mecanismos de utilização, como ele é apresentado aos espectadores, o viés da recepção e as possibilidades de utilização e, por outro lado, como se produz nesse meio, entendendo as características das metodologias de criação que antecedem a apresentação de conteúdos em vídeo ao público. Queremos, portanto, elencar como o desenvolvimento de formatos de vídeo, do analógico ao digital, foi modificando a relação do vídeo com a televisão, o cinema e o computador em um processo mútuo nessa relação entre linguagem de uso e de produção. Na linguagem de uso reside, no entanto, aquele perigo ao qual nos referimos anteriormente, de compreender o vídeo em sua forma de exibição de outras mídias, abordagem que procuraremos nos desviar. Para pensarmos como as modificações de formatos de gravação e armazenamento de vídeo proporcionaram uma série de diferentes experimentações entre artistas, foi importante realizar um mapeamento prévio desses principais formatos e suas características e contextos de surgimento, conforme tabela abaixo:

\begin{tabular}{|l|l|l|}
\hline FORMATO & ANO & DESCRIÇÃO \\
\hline Portapak & 1965 & $\begin{array}{l}\text { Inicialmente desenvolvido e introduzido pela Sony em 1965, o 'Portapak' foi } \\
\text { um formato de gravação de vídeo altamente portável, e relativamente barato de } \\
\text { meia polegada e preto e branco com câmera dedicada. Essa máquina foi logo } \\
\text { reconhecida por artistas como uma ferramenta ideal para o registro de } \\
\text { performances, eventos e 'happennings' no final da década de 1960 e início dos } \\
\text { anos 1970 (...). Existiram várias versões do Portapak, começando com a } \\
\text { introdução com a máquina de 405 de baixa densidade na Europa } \\
\text { (eventualmente substituída pela versão de 625 linhas) e a máquina de 525 linhas } \\
\text { (nos Estados Unidos), denominada EIAJ-1. Esses dois formatos eram } \\
\text { incompatíveis (MEIGH-ANDREWS, 2014, p. 345 , tradução nossa). }\end{array}$ \\
\hline U-Matic & 1970 & $\begin{array}{l}\text { Comercializada em 1974. “(..) marca registrada de um sistema de videocassete } \\
\text { que emprega fitas de 3/4 de polegadas e que é utilizado em produções de caráter } \\
\text { profissional ou semi profissional”.(MACHADO, 1988, P. 220) }\end{array}$ \\
\hline Video-Disco Laser & 1972 & $\begin{array}{l}\text { Produzida pela Philips. “Sistema de vídeo que emprega como suporte um disco } \\
\text { de leitura a laser no lugar da fita magnética. (MACHADO, 1988, P. 221). }\end{array}$ \\
\hline Betamax & 1975 & $\begin{array}{l}\text { "Marca registrada de um sistema de videocassete que emprega fitas de meia } \\
\text { polegada e que é utilizado predominantemente para finalidades domésticas” } \\
\text { (MACHADO, 1988, p. 208). }\end{array}$ \\
\hline VHS & 1977 & $\begin{array}{l}\text { “'Video Home System'. Um formato de videocassete doméstico baseado em fitas } \\
\text { de meia polegada e desenvolvido pela JVC (MEIGH-ANDERS, 2014p. 346, } \\
\text { tradução nossa). }\end{array}$ \\
\hline Betacam & 1982 & $\begin{array}{l}\text { Produzido pela Sony. "Marca registrada de um sistema integrado de gravador } \\
\text { de câmera, que grava em fitas meia polegada com qualidade broadcasting” } \\
\text { (MACHADO, 1988, p. 208). }\end{array}$ \\
\hline SVHS & $\begin{array}{l}\text { “Aperfeiçoamento do sistema VHS, que compreende maior resolução } \\
\text { horizontal e qualidade broadcasting” (MACHADO, 1988, p. 219) }\end{array}$ \\
\hline
\end{tabular}




\begin{tabular}{|c|c|c|}
\hline D1 & 1986 & $\begin{array}{l}\text { "Sony/Bosch/BDS formato de vídeo digital introduzido em 1986" (MEIGH- } \\
\text { ANDREWS, 2014, p. 342, tradução nossa). }\end{array}$ \\
\hline D2 & 1988 & $\begin{array}{l}\text { “Apex formato de vídeo digital introduzido em1988” (MEIGH-ANDREWS, } \\
\text { 2014, p. 342, tradução nossa). }\end{array}$ \\
\hline D3 & 1991 & $\begin{array}{l}\text { "Formato de vídeo digital introduzido pela Panasonic em 1991" (MEIGH- } \\
\text { ANDREWS, 2014, p. 342, tradução nossa). }\end{array}$ \\
\hline Betacam Digital & 1993 & $\begin{array}{l}\text { “(...) formato de vídeo digital desenvolvido pela Sony e lançado em } 1993 \\
\text { baseado no formato Betacam” (MEIGH-ANDREWS, 2014, p. 342, tradução } \\
\text { nossa). }\end{array}$ \\
\hline DV & 1995 & $\begin{array}{l}\text { "Formato de videotape digital lançado em } 1995 \text { por um consórcio de } \\
\text { equipamentos de vídeo, incluindo a JVC, Panasonic e Sony". (MEIGH- } \\
\text { ANDREWS, 2014, p. 343, tradução nossa). }\end{array}$ \\
\hline HDV & & $\begin{array}{l}\text { "Formato de vídeo de gravação de imagens em alta definição em fitas cassetes } \\
\text { DV desenvolvido pela JVC (MEIGH-ANDREWS, 2014, p. 343, tradução } \\
\text { nossa). }\end{array}$ \\
\hline DVD & 1995 & $\begin{array}{l}\text { Sigla de Digital Versatile Disc, trata-se de um formato de disco que permite } \\
\text { gravar informações em formato digital com capacidade de armazenar um total } \\
\text { de } 4.7 \text { GB de dados e traz uma qualidade de imagem de }\end{array}$ \\
\hline Blu Ray Disc & 1998 & $\begin{array}{l}\text { Tipo de DVD com alta capacidade de gravação de dados digitais com vídeo e } \\
\text { alta resolução, com capacidade de armazenamento de } 27 \mathrm{~GB} \text {. }\end{array}$ \\
\hline HDTV & & $\begin{array}{l}\text { Sigla para High-definition television, sistema com uma resolução de tela de } \\
\text { 1080x1920 pixels. }\end{array}$ \\
\hline $\begin{array}{l}\text { ULTRA HDTV } 4 \mathrm{~K} \\
\text { Televisão }\end{array}$ & & $\begin{array}{l}\text { O padrão } 4 \mathrm{~K} \text { consiste na captação e transmissão com uma qualidade de } \\
\text { resolução quatro vezes maior do que as televisões digitais comercializadas hoje } \\
\text { em FULL HD, o que significa um total de } 3.840 \times 2.160 \text { pixels. }\end{array}$ \\
\hline $\mathrm{DCP} 2 \mathrm{~K}$ & & Sigla para Digital Cinema Package com resolução total de $2.048 \times 1.080$ pixels. \\
\hline DCP 4K & & $\begin{array}{l}\text { Sigla para Digital Cinema Package com resolução de tela total de } 4.096 \times 2.160 \\
\text { pixels. }\end{array}$ \\
\hline $\begin{array}{l}\text { Super ultra HDTV ou } \\
\text { UHDTV2 } 8 \mathrm{~K}\end{array}$ & & $\begin{array}{l}\text { Sigla para Ultra High Definition Television, televisão de alta definição com } \\
\text { resolução de tela de } 7.680 \times 4.320 \text { pixels. }\end{array}$ \\
\hline
\end{tabular}

Tabela 01: Formatos de gravação, armazenamento e transmissão de vídeo

Tecnicamente falando, e como demonstrado na tabela acima, o vídeo encontra suas características tanto em um processo analógico quanto digital. As primeiras produções de videoarte, por exemplo, tiraram grande proveito de algumas das características que esse estado analógico proporcionava, gerando possibilidades de espacialização (os quais analisaremos mais de perto adiante) nas décadas de 1960 e 1970 e que ainda reverberam na arte contemporânea, agora majoritariamente produzidas no âmbito do digital. Na imagem analógica, segundo Arlindo Machado:

(...) produz-se uma analogia entre cada valor luminoso da imagem e uma quantidade correspondente de eletricidade. A imagem, convertida, portanto, em energia elétrica, ganha as propriedades desta última, podendo ser enviada de um lugar a outro, por cabos ou por ondas eletromagnéticas, bem como ser registradas em fitas de compostos metálicos. Só que a circulação de sinais, na codificação analógica, não se dá sem perda 
de definição. (...) Essa característica da imagem eletrônica traz sérios problemas, principalmente pra a geração de efeitos especiais, que exige grande número de passagens de uma fita a outra. É verdade que a geração de artistas que criou a vídeoarte soube tirar proveito dessa degeneração, explorando justamente a transfiguração da imagem possibilitada pelas passagens sucessivas. (MACHADO, 1988, p. 30) $+$

Essa imagem analógica do vídeo que surgiu com a televisão e será apropriada pelos videoartistas é ainda uma imagem de baixa definição. Machado (1988) indica que essa relação entre alta e baixa definição caracteriza-se pelo maior ou menor número de pontos de informação em um determinado espaço da tela. A alta definição seria desse modo aquele âmbito e que uma quantidade alta de unidades de informação (grão da película cinematográfica ou o pixel, por exemplo) se apresentam e, quanto maior a quantidade de informação, mais possível será se aproximar da representação fiel de uma realidade visível em suas nuances de cores, profundidade, tonalidade, entre outros. Como demonstrado acima, essas foram questões que serviram de ponto de exploração para esses primeiros videoartistas, que não necessariamente estavam preocupados com um movimento de aproximar suas imagens de uma abordagem o mais figurativo possível.

Ao contrário disso, esses artistas exploraram essas "limitações" como matéria-prima para suas experimentações e partiram disso para edificar uma série de métodos para a apresentação de um espaço diferenciado na tela do vídeo. Nessa linha uma série de aparelhos, chamados sintetizadores foi inventada pelos próprios artistas, um exemplo é o Direct Video Synthesizer de Stephen Beck ${ }^{1}$, que para o artista tratava-se de um aparelho de escultura eletrônica gerando os quatro principais aspectos do vídeo, a cor, forma, movimento e textura, produzindo assim uma série de vídeos que se aproximavam de uma abordagem abstrata. Os sintetizadores tratavam-se de aparelhos que geravam imagens a partir dos próprios elementos que constituíam a linguagem eletrônica, intervindo sobre o fluxo de elétrons que a compõe. Para Machado (1988) algumas operações advindas desses sintetizadores foram essenciais, tais como o feedback ${ }^{2}$, a colorização ${ }^{3}$ e a que mais nos interessa, a questão da inserção. Sobre esta última, o autor define como a inserção de uma imagem na outra, basicamente o efeito chroma-

1 Artista norte americano pioneiro no trabalho com sintetizadores de vídeo, estudou na Universidade de Illinois onde desenvolveu alguns de seus experimentos entre os anos de 1968 e1969.

2 "realimentação ou auto-alimentação. Em vídeo, é o nome que se dá ao efeito gerado por um circuito fechado onde a câmera é apontada para a tela do mesmo monitor que exibe a imagem que ela capta. O resultado é uma espiral caleidoscópica móvel, que pode ser modificada infinitamente, a partir de qualquer manipulação da câmera. Também conhecido como efeito Larsen ou Howl" (MACHADO, 1988, p. 212)

3 "Colorizador: aparelho destinado a colorir imagens preto-e-branco ou a modificar as cores de uma imagem colorida. Na versão analógica, a máquina traduz tons de cinza para um código cromático. Na versão digital, um computador memoriza as cores colocadas previamente num único quadro e as repete nos quadros sucessivos, obedecendo aos deslocamentos da figura" (MACHADO, 1988, p. 210). 
key que apresentaremos no terceiro capítulo deste trabalho.

Essas considerações podem parecer historicamente localizadas, no entanto, o encontro com os trabalhos que analisaremos mais à frente mostrará como algumas dessas questões enquanto prática de espacialização ainda são pertinentes na produção de videoarte produzida a partir da década de 1990 até os dias de hoje, com a diferença de que, provavelmente, esses processos de edição e espacialização são elaborados no âmbito do digital, do computador. Elencamos como importante elemento histórico no desenvolvimento analógico do vídeo (como já discutido por uma série de autores) o lançamento em 1965 do Portapak da Sony. O grande trunfo desse equipamento foi a sua facilidade na operação, portabilidade, acessibilidade financeira e o fato de estar apto a ser utilizado no ambiente doméstico ou nos estúdios dos artistas que o adquiriram nessa época. O formato analógico, no entanto, mesmo com o Portapak, manteve algumas dificuldades recorrentes para edição de material gravado.

Acreditamos ser a introdução da edição não-linear o principal fator de aumento e popularização de uma prática de experimentações em espacialização interna do vídeo. Isso se torna ainda mais frequente na década de 1990 com o processo de digitalização e surgimento de ferramentas como Adobe Premiere e Final Cut PRO, e tem suas premissas em máquinas de edição do formato U-MATIC, por exemplo, como o VO2850 e o VO2860, citados por MeighAndrews. Essas tecnologias possibilitaram um processo de edição mais democrático que poderia ser realizado também de maneira doméstica, o que se compara à mudança que o surgimento do Portapak proporcionou na década de 1960.

Com o surgimento da imagem digital uma modificação importante tomou conta do campo do vídeo enquanto técnica, a alta resolução da imagem de vídeo. Essa alta resolução permitiu que o vídeo agora fosse apresentado em grandes dimensões principalmente a partir do advento do projetor digital. É nesse percurso que o que Phillippe Dubois (2004) chama estadovídeo atinge seu ápice, já que passa a atravessar todas as mídias de imagem em movimento no âmbito da linguagem de uso. Sobre o âmbito do digital e a relação com a televisão, Machado declara:

Com a codificação digital (...) atribui-se um valor numérico a cada ponto de luz da imagem, de forma que este último pode ser colocado na memória de um computador, manipulado à vontade, copiado quantas vezes for preciso e depois convertido novamente em imagem, sem qualquer perda de definição. A digitalização eletrônica faz desaparecer, portanto, qualquer diferença entre a imagem original e sua cópia. (...) Como consequência, o universo dos efeitos visuais ampliou-se ao infinito. (...) Processados através de computadores, os códigos numéricos correspondentes aos sinais eletrônicos podem sofrer praticamente qualquer sorte de manipulação, e essa potencialidade acabou por se converter na própria natureza dessa televisão: a tevê digital, como veremos adiante, é a mídia por excelência dos efeitos especiais. (MACHADO, 1988, p. 30). 
O surgimento do computador permite, portanto, o aparecimento de um processo diferenciado de captura e edição das imagens em vídeo, que agora com sua alta qualidade de imagem passa a percorrer caminhos que vão para além da apropriação daquela baixa definição como matéria-prima de trabalho. Importante aqui ressaltar que para Lev Manovich (2001) a questão da alta definição da imagem digital, apresentada por Machado, é em parte um mito construído, já que o autor discute as questões de compressão do digital em formatos como o JPEG e o MPEG, onde há sim perda de definição e informação quando se refere ao conteúdo "original".

A utilização doméstica digital do cinema a partir dos DVD's e Blu-Rays cresce, a televisão continua sua empreitada no vídeo em formatos como o ULTRAHDTV $4 K$, bem como o monitor do computador, que utiliza da interface do vídeo para visualização de dados. Embora suas imagens possam ser produzidas sem a captura de imagens por câmeras, é a partir do sinal de vídeo e no monitor que podemos entrar em contato com essas informações produzidas no computador e, portanto, o cruzamento torna-se claro. Essas questões de passagens são assim retomadas por Arlindo Machado em 2007 ao dizer que:

\begin{abstract}
Curiosamente, comemoramos a maioridade do (...) vídeo num momento em que todo um discurso corrente parece decretar a morte do vídeo, superado que teria sido pelas tecnologias digitais e pelas formas "virtuais" de difusão nas redes telemáticas. Questão de ponto de vista. Mas se considerarmos vídeo a sincronização de imagem e som eletrônicos, sejam eles analógico ou digitais, se entendermos imagem eletrônica como aquela constituída por unidades elementares discretas (linhas e pontos) que se sucedem em alta velocidade na tela, então podemos concluir que hoje quase tudo é vídeo e que, longe de estar moribunda, essa mídia acabou por ocupar um lugar hegemônico entre os meios expressivos de nosso tempo. O que é o "cinema digital" senão uma forma de vídeo? O que são os formatos digitais de animação na Net senão formas de vídeo? A computação gráfica, o videogame, as animações interativas de toda espécie não se apresentam fundamentalmente ao receptor como imagens e sons eletrônicos e, portanto, como vídeos? O cinema não é hoje fruído majoritariamente em forma de vídeo? Si la vidéo est mort, vive la vidéo!" (MACHADO, 2007, p. 16).
\end{abstract}

Existe, no entanto, uma diferença que deve ser apontada entre esse vídeo quando apresentado em uma tela de televisão ou em um monitor de computador, a da varredura que compõe a imagem nesses dois momentos. Almir Almas (2013) define a varredura como o processo de movimento rápido descrito pelo feixe de elétrons no tubo de raios catódicos de um monitor ou receptor de TV, constituído por linhas ao longo de dada superfície foto-sensível da tela para produzir as imagens de vídeo em um movimento contínuo. A partir desse processo de varredura outras duas situações se instauram quando falamos do vídeo, a da varredura entrelaçada e a da varredura progressiva. Ainda segundo Almas na primeira vemos a formação da imagem de vídeo a partir do tubo da televisão tradicional onde dois campos de varredura são 
formados, um com as linhas ímpares e outro com as linhas pares que se entrelaçam da direita para esquerda e de cima para baixo. Já a varredura progressiva está associada à forma como os monitores de computador formam suas imagens, onde apenas um campo é apresentado e todas as linhas são exibidas ao mesmo tempo a partir das informações que são enviadas para cada pixel. Embora formado por processos diferentes esses dois casos são considerados vídeo, e a imagem progressiva cada vez mais toma conta da produção das imagens nas telas contemporâneas, do computador às televisões domésticas, e nessa situação técnica reside o argumento apresentado por Arlindo Machado na citação acima. No entanto, nos perguntamos mais uma vez, onde reside a autonomia do vídeo enquanto objeto artístico a partir do advento desses cruzamentos técnicos? Há necessidade da busca por essa autonomia?

Para isso, tentamos apresentar como essas questões relacionadas ao desenvolvimento tecnológico do vídeo influenciaram o surgimento de uma possível estética própria dessa mídia. É importante, no entanto, verificarmos como o desenvolvimento de uma linguagem do vídeo no que conhecemos como videoarte tem precedentes nas experimentações e técnicas da linguagem da televisão e do cinema, e se desdobra na relação intrínseca com a linguagem computacional a partir do advento das mídias digitais. Partimos da ideia de que o processo de expansão da linguagem videográfica está intrinsecamente relacionada aos mecanismos de espacialização do vídeo, tanto internamente (em propostas mono-canal) quanto em desdobramentos para o espaço expositivo nas videoinstalações. Desta forma, queremos elencar algumas características dos cruzamentos entre televisão, cinema, computador e o vídeo e suas espacializações.

Michael Rush (2014) indica que com o surgimento do vídeo três práticas principais emergiram: 1) artistas que utilizaram o vídeo para realizar intervenções quantitativas e qualitativas a partir da exibição de videoartes na programação televisiva perpetuada em grande escala; 2) Artistas que criaram modelos alternativos de televisão, como as TVS comunitárias; 3) artistas que utilizaram o vídeo como meio de extensão de suas práticas já consolidadas nas artes plásticas, exibidos geralmente no circuito de galerias de arte. Em todos esses aspectos a relação com o tempo presente, natureza do processo de transmissão direta da televisão está colocada.

Essa relação é evocada no campo da arte pelo que Michael Rush chama do advento de um corpo conceitual. Essas produções ganham força no território da arte, segundo o autor, a partir das action paintings de Jackson Pollock e passam a atravessar uma série de outras linguagens, inclusive, e principalmente, nas primeiras produções de videoarte. A disponibilização dos primeiros equipamentos domésticos de gravação em videotape chamou a 
atenção de artistas de campos diversos: do conceitualismo, performance, escultura, desenho, entre outros, que passaram a utilizar o vídeo como um elemento de exibição, problematização e registro de suas ações performáticas que com o tempo passaram a ser pensadas exclusivamente para a câmera. A dificuldade de edição dos materiais em videotape materializam no registro dessas ações de artistas a partir da fita magnética uma espécie de metáfora de registro desse tempo presente da televisão, ações do corpo para o vídeo que são contínuas e com poucos ou nenhum corte. Podemos citar como exemplo os trabalhos de artistas como Vito Acconci, Bruce Nauman, Marina Abramovic, entre outros. No Brasil a primeira geração de videoartistas na década de 1970 é exemplar para a discussão dessas relações a partir dos trabalhos de Paulo Herkenhoff, Anna Bella Geiger, Letícia Parente, Sônia Andrade. Rosalind Krauss (2008) problematiza essas questões ao apontar que as primeiras produções de vídeo perpetuam uma estética do narcicismo, em que esse corpo (que é central no quadro videográfico) situa-se entre duas máquinas: a câmera que capta a imagem, e o monitor que a exibirá, de onde um outro elemento aparece, a presença do espectador em contra-campo e que visualiza esse corpo centralizado da performance em vídeo. Remonta-se aqui à utilização do aparelho de gravação como um espelho, o artista fala para si, mas, ao mesmo tempo, fala para o outro lado, para o contra-campo, em que reside o espectador.

Essa qualidade segundo Bellour trata-se também de um enfrentamento da própria natureza da recepção da televisão no ambiente doméstico, uma maneira de ativar esse espectador falando diretamente com ele a partir de mecanismos diversos, uma espécie de trabalho para demonstrar um avesso do campo da televisão, pelo viés de operações como o close-up, o olhar do performer direcionado para a câmera, o silenciamento do quadro, citando como exemplo a obra Reverse television ${ }^{4}$ (1993) de Bill Viola. Nesses trabalhos, portanto, uma questão de espacialização importante é integrada na relação com a prática de subverter o campo que não é o da tela de televisão, mas o da vida cotidiana de quem a está assistindo no ambiente doméstico.

A discussão do espaço se instaura na medida em que o artista se direciona fundamentalmente ao contra-campo. Apesar dessas questões terem surgido nos primeiros anos de produção de videoarte, essas caraterísticas se tomaram um fator importante para a presença

4 Neste trabalho segundo Raymond Bellour (1997) "Quarenta e quatro pessoas, com idade entre 16 e 93 anos, sentadas em frente a câmera no lugar em que normalmente assistem à televisão, deveriam aparecer cada uma durante um minuto, em silêncio, sem serem anunciados nem elas nem o canal em que estariam sintonizadas, de hora em hora, durante várias semanas, entre os programas, num canal público (WGBH Boston), no espaço em que o canal faz sua propaganda interna. Em lugar disso, esses retratos foram transmitidos durante apenas duas semanas (14-28 de novembro de 1983), cinco vezes por dia, durante 30 segundos cada um (...)" (BELLOUR, 1997, p. 66-670). 
desse corpo conceitual no vídeo. Produções dos últimos anos ainda procuram esse enfrentamento do qual falamos. Citamos como exemplo os vídeos Soco na imagem de Danillo $\operatorname{Barata}^{5}$ (2007) e Eko Kanhy (2012) de Luciana Magno ${ }^{6}$.

O primeiro vídeo inicia-se com um quadro branco a espera de um assunto que possa emergir. Em seguida o artista entra em campo desnudo em plano médio e por alguns segundos, imóvel, parece encarar a câmera que realiza aquele registro para em seguida começar a proferir movimentos rápidos e nervosos de soco em direção a essa mesma câmera. Portanto, ação de um embate, de luta com a câmera reflete também uma tentativa de estabelecer ligação com esse contra-campo, um desafio da imagem para o espectador mediado pelas ações do corpo do artista. Esse trabalho de desafiar o outro lado é reforçado justamente por essa atmosfera de luta que é imposta, os sons dos golpes emitidos introduzem um certo teor de medo e ao mesmo tempo de dor. A cada um desses golpes o corpo do artista se deforma e se transforma em uma presença de vultos, quase fantasmática que se dilui no fundo branco. Enquanto o início do vídeo direciona nossa visão para uma centralidade do espaço do quadro, a partir do corpo que ali se instala, os momentos seguintes expandem a atenção dessa espacialidade do quadro em sua totalidade justamente por essa dissolução da imagem do corpo em função dos golpes proferidos por movimentos extremamente rápidos.

Essa atitude de confronto surge no trabalho de Luciana Magno de maneira muito mais sutil. No vídeo de apenas um minuto a artista também aparece inicialmente no centro do quadro e em plano médio. $\mathrm{O}$ ambiente trata-se de um rio, onde metade do corpo de Magno se encontra submerso nessas águas e, ao fundo, folhagens de uma árvore completam o quadro. A artista está vestida com uma roupa de dormir branca que foi utilizada por sua avó na noite de núpcias, o que logo levanta questões de uma memória afetiva que pode residir nessa relação entre corpo, vestimenta e submersão. O confronto sutil com o contra-campo se encontra no simples olhar fixo da artista direcionado para esse espaço externo ao quadro, ou o que estaria por trás da

5 "É artista, curador e professor. Doutor em Comunicação e Semiótica pela Pontifícia Universidade Católica de São Paulo e Mestre em Artes Visuais pela Universidade Federal da Bahia. Sua obra articula performance e imagem, e tem como centro as relações entre o corpo, câmera, sistema da arte e mundo. Possui obras nos acervos do Museum der Weltkulturen Frankfurt (Alemanha), da World Wide Visual Factory (Holanda) e do Museu de Arte Moderna da Bahia. Foi premiado no $16^{\circ}$ Vdeobrasil. Vive e trabalha em São Felix, Bahia." Fonte: www.videobrasil.org.br

6 "É artista, graduada em Artes Visuais e Tecnologia da Imagem pela Universidade da Amazônia, Belém, e Mestra em Artes pela Universidade Federal do Pará, na mesma cidade. Trabalha com performance, frequentemente direcionada para fotografia e vídeo, objeto e website. Suas obras já foram exibidas no Centro Cultural Banco do Nordeste, Fortaleza (2014); no Arte Pará, Museu de Arte do Pará, Belém (2014), onde foi artista premiada; no Mueu de Arte do Rio de Janeiro (2013). Foi ganhadora da $10^{a}$ edição do Programa Rede Nacional Funarte Artes Visuais com o projeto Telefone sem Fio. Ganhadora do prêmio de Residência Delfina_Videobrail (Londres, Reino Unido) no $19^{\mathrm{a}}$ Festival de Arte Contemporânea Videobrasil." Fonte: www.videobrasil.org.br 
câmera de gravação. Durante esse um minuto de vídeo Magno aos poucos submerge nas águas desse rio até que seus cabelos castanhos compridos, marca dos trabalhos da artista, se confundem com a água barrenta e em seguida desaparecem completamente. As relações com o quadro se estabelecem, portanto, em dois momentos: o contra-campo que é sugerido durante toda a duração do vídeo a partir do olhar fixo da artista nessa direção, e em um segundo momento a partir do processo de submersão. Mais do que submergir no rio Magno confronta e expõe nesse momento um dos seis segmentos de espacialidade da tela que Nöel Burch se preocupa em delimitar. O abaixo da tela, essa base, já aparece materialmente fluida e diluível na medida em que se trata do elemento água e no momento que a artista inicia o processo de submersão essa característica se potencializa. O quadro ganha força nesse segmento de base, o corpo o qual vemos desaparecer se direciona para algum lugar que está fora daquele enquadramento e que só podemos localizar a partir de um processo imaginativo. Magno confere força, portanto, ao espaço imaginativo que pode aparecer para além dos limites das bordas da tela.

Nesses dois trabalhos vemos a problematização daquele quadro-janela que Aumont (2005) levanta, uma exploração substancial dos espaços externos aos determinados pelo limite dos quadrantes da tela. O caráter imaginativo deste espaço-fora-da-tela, as extensões das bordas visuais tomam forma por mecanismos como o soco direcionado de Barata ou o olhar e a submersão de Magno. As discussões espaciais aqui, portanto, não atingem o nível da composição com planos diferenciados, mas é importante apontar como esses outros procedimentos podem nos levar à problematização desse espaço do quadro, desde os corpos centralizados, à diluição da atenção no espaço do quadro no trabalho de Barata, passando ao reforço da base como elemento de surgimento de uma imaginação do espaço em Magno, ambos atravessados por esse olhar também imaginativo para o contra-campo.

A relação com o tempo presente na videoarte não é, no entanto, apenas metaforizada pelos registros de ações, esse tempo lida diretamente com o espaço físico nas instalações de videovigilância por exemplo. A instalação de circuitos fechados de vídeo faz uma espécie de retomada do corpo do espectador que se via nas imagens instaladas nesses lugares, e uma espécie de deslocamento ou distorção da experiência espacial acontecia. Sobre isso, Michael Rush aponta que: 


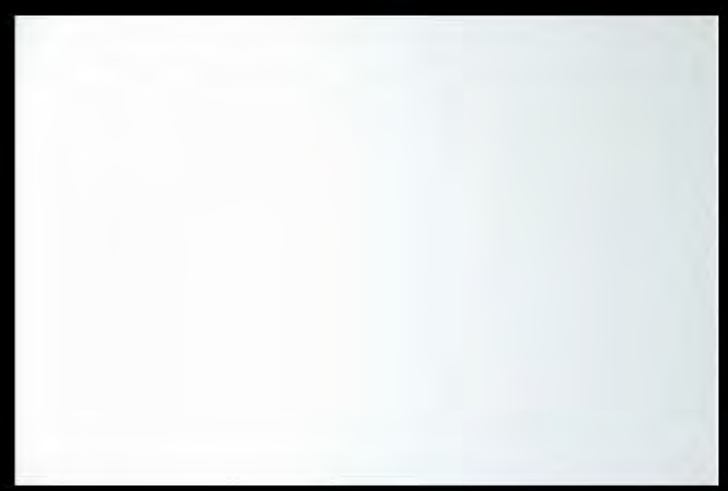

$11^{n}$

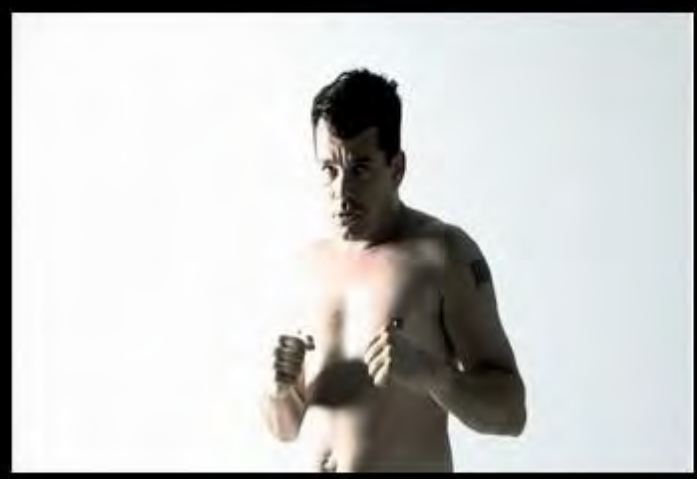

1'34"

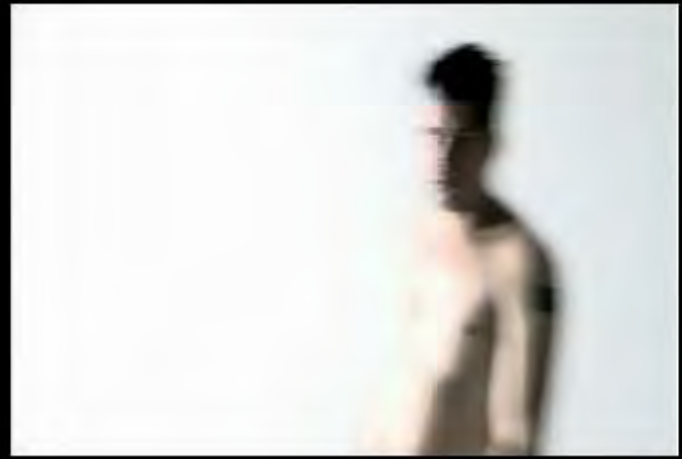

$6^{\prime} 08^{\prime \prime}$

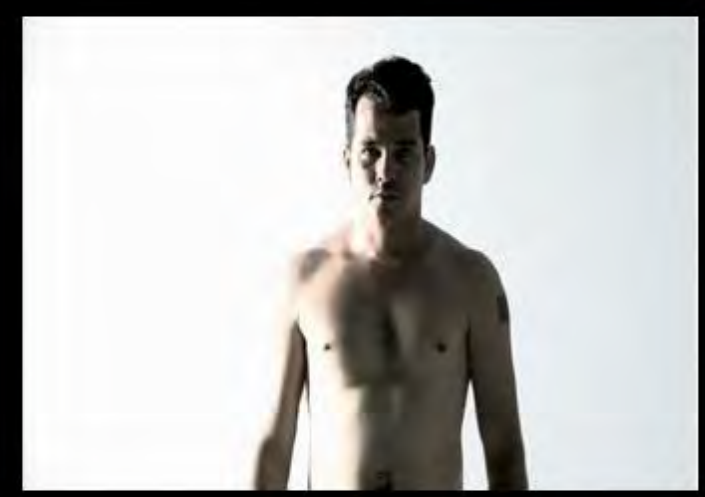

$22^{n}$

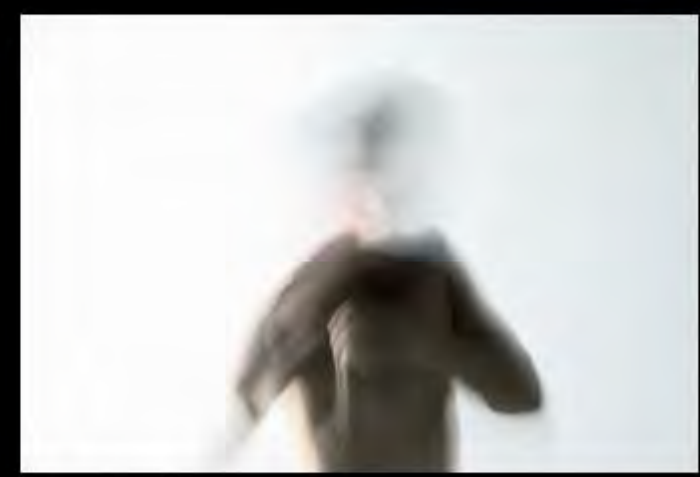

$4^{\prime} 58^{\prime \prime}$

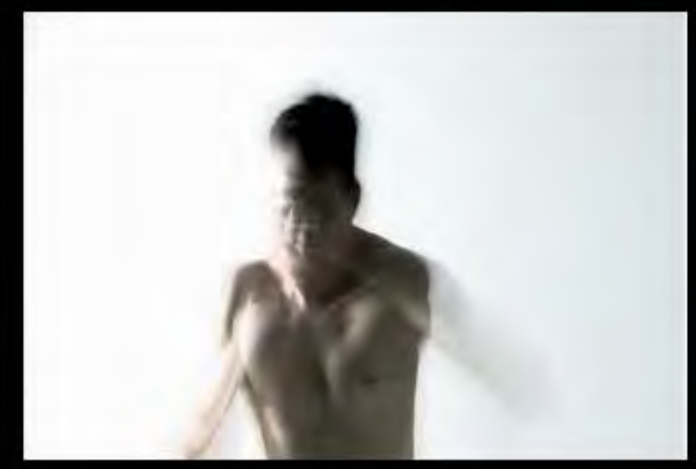

$6^{\prime} 23^{\prime \prime}$

Ilustração 02: Frames do vídeo Soco na imagem (2007), de Danillo Barata Fonte: Acervo da Associação Cultural Videobrasil 

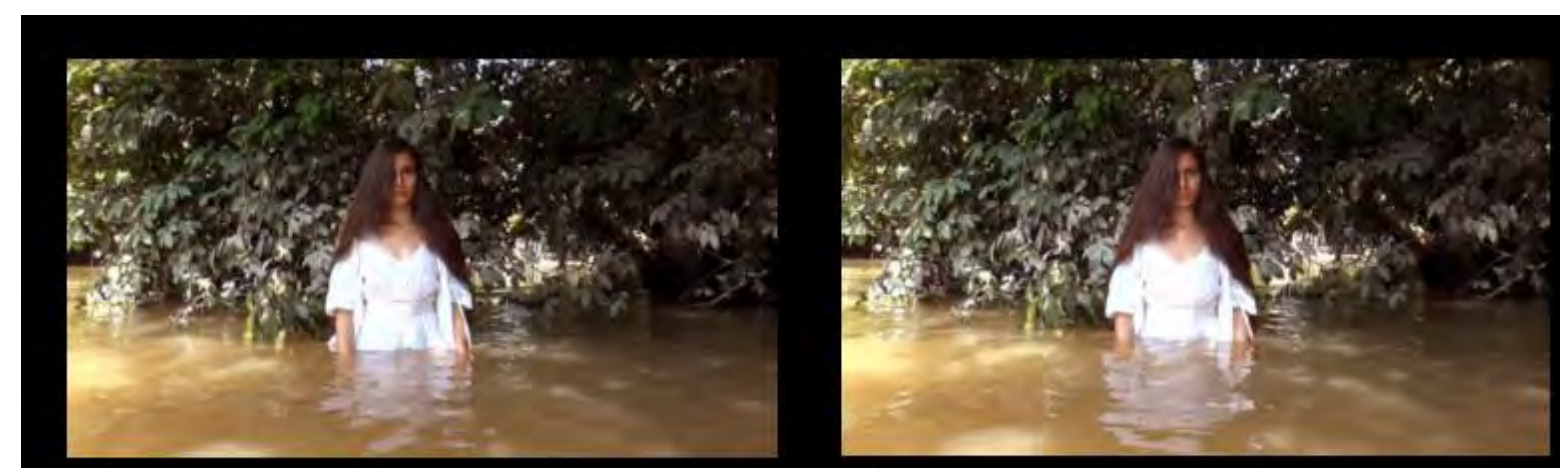

$02^{n}$

$07^{n}$
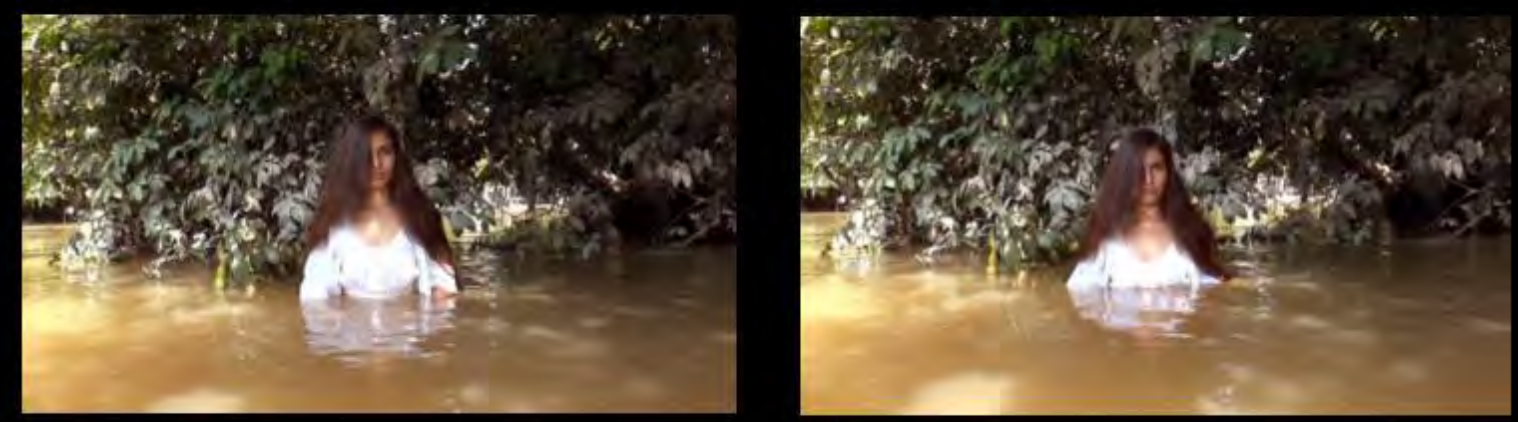

$20^{n}$

$30^{n}$

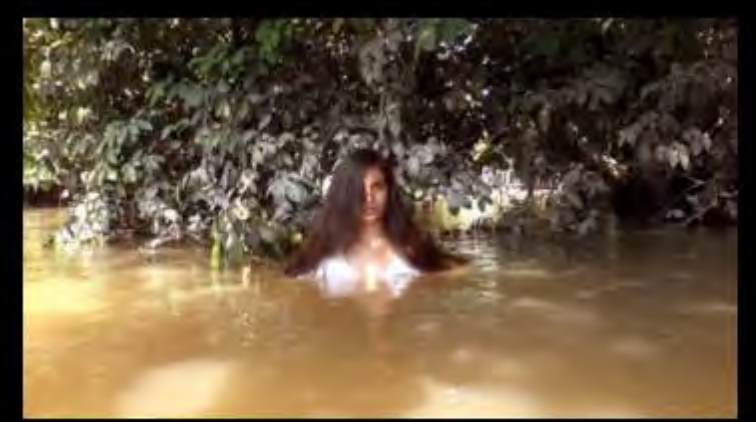

$40^{m}$

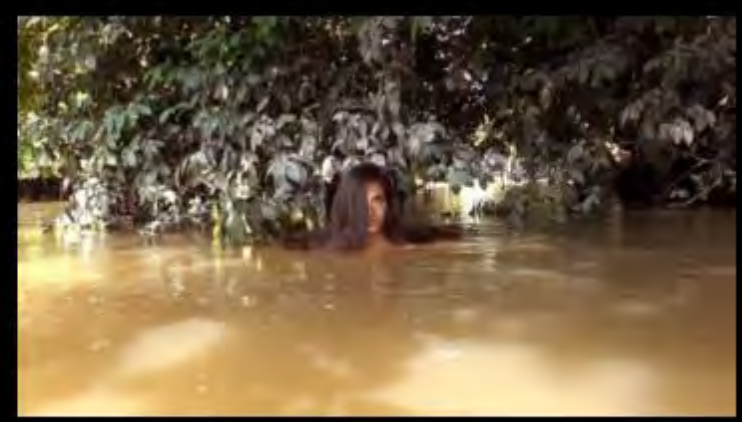

$50^{\prime \prime}$

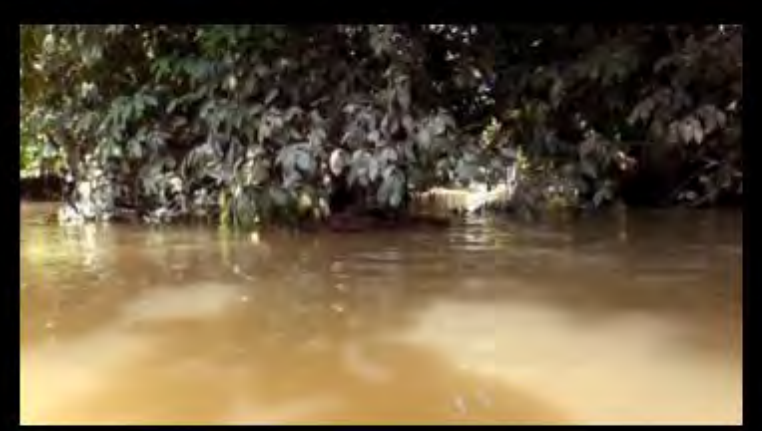

$58^{n}$

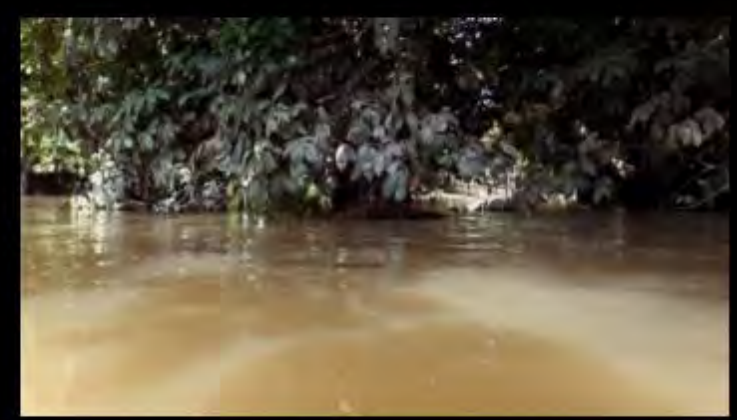

$01^{\prime}$

Ilustração 03: Frames do vídeo Eko Kahny (2012), de Luciana Magno

Fonte: Acervo do projeto de pesquisa "Acervo de Videoarte paraense: sistematização e análise crítica" (CNPq/SEC/MinC - 2014-2016). 
O interesse em vigilância surgiu não apenas de revelações públicas na imprensa sobre práticas reais de policiamento, mas também da própria natureza da televisão, que parece estar observando constantemente o espectador, mesmo quando este a observa. As instalações de "arte vigilante" confrontaram diretamente esta qualidade reflexiva da televisão e devolveram a responsabilidade de ver ao espectador, que se entrega a um relacionamento passivo com a tela de TV. (RUSH, 2006, p. 116)

As práticas de videovigilância são, portanto, mais um índice da tentativa de instauração daquele avesso da televisão de que Bellour falava, uma tentativa de rearticular as relações campo e contra-campo da fruição doméstica da televisão, energizando a presença do corpo do espectador pela própria consciência de visualização do seu corpo no espaço a partir de uma experiência efêmera de imagem que a transmissão direta permite. Um exemplo clássico desse tipo de prática é o trabalho Live-Taped Video Corridor (1970) de Bruce Nauman?

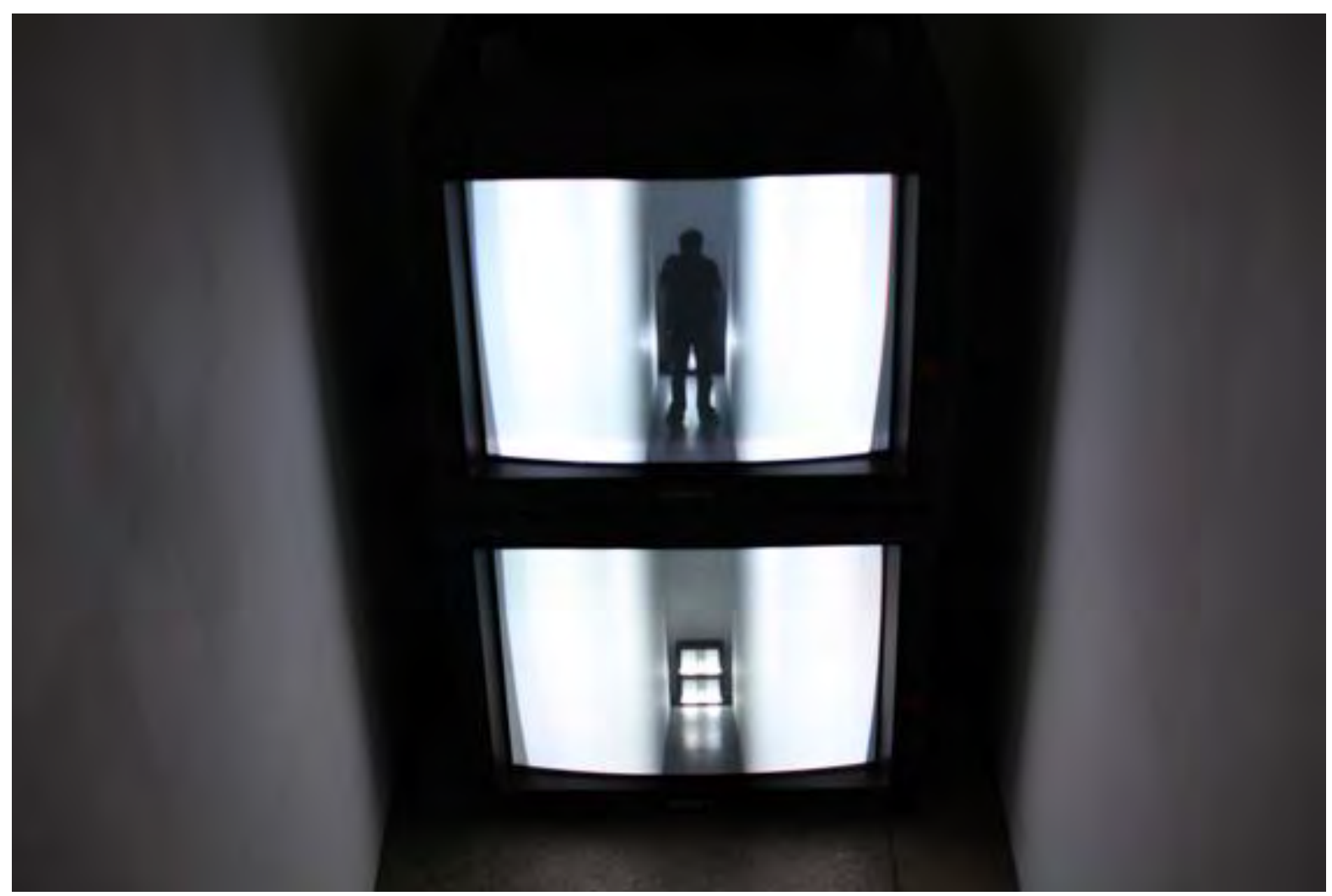

Ilustração 04: Monitores integrantes da instalação Live-Taped Video Corridor (1970), de Bruce Nauman Fonte: www.repia.art.br

\footnotetext{
${ }^{7}$ Artista norte americano reconhecido por seus ambientes, filmes e vídeos. Naceu em Forte Wayne, Indiana. Estudou matemática na Universty of Wisconsin em Madison (1960-1964) e artes na University of Galiforna em Davis (1965-1966). Fonte: www.tate.org.uk
} 


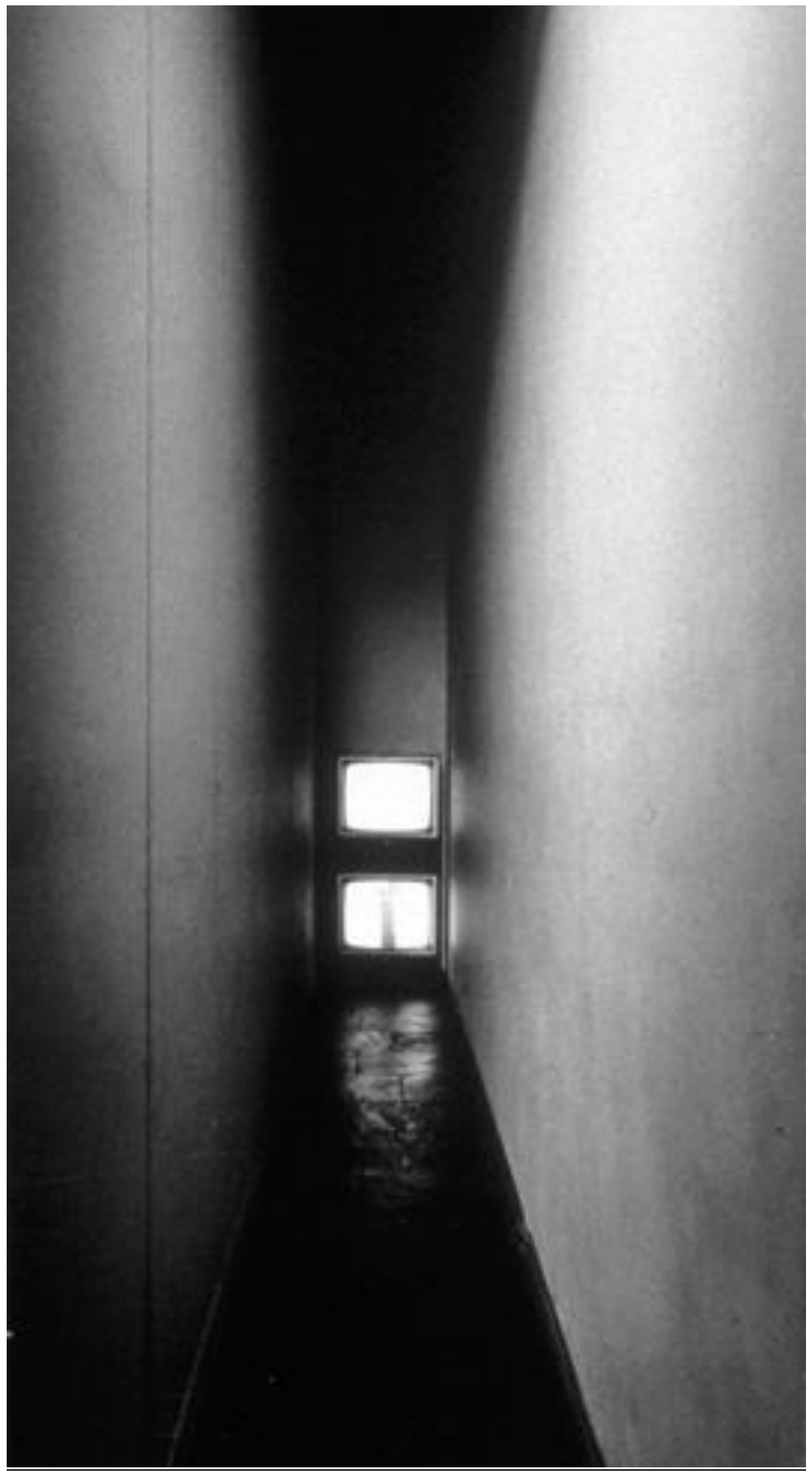

Ilustração 05: Plano geral da instalação Live-Taped Video Corridor (1970) de Bruce Nauman na Nicolas Wilder Gallery em Los Angeles (EUA)

Fonte: www.guggenheim.org/artwork/315 
A obra é constituída por duas paredes com dimensões que vão do chão ao teto colocadas lado ao lado a uma distância de aproximadamente 50 centímetros. Ao fim desse corredor construído dois monitores se encontravam no chão, um sobre o outro e ligados a câmeras instaladas na parte superior da entrada. O monitor de TV localizado embaixo exibia imagens pré-gravadas do corredor, mostrando apenas os próprios monitores ao fundo, enquanto o segundo monitor exibia imagens ao vivo desse mesmo corredor. Os espectadores são convidados a entrar nesse espaço claustrofóbico e percorrê-lo até o final onde poderiam visualizar melhor as imagens que eram exibidas no monitor. O jogo espacial aqui reside justamente nessa visualização. Enquanto encontra-se na entrada do corredor o espectador se vê de costas no monitor superior, mas a distância entre a entrada do corredor e os monitores não deixa que essa visualização seja tão eficiente, o que motiva o deslocamento em direção ao fundo.

À medida que se aproxima do monitor esse espectador vê a imagem do seu corpo diminuir de tamanho, já que se distancia da câmera que captura aquela imagem ao vivo. Nauman aqui subverte a ideia de que uma aproximação espacial sugere necessariamente uma proximidade de visualização, problematiza a relatividade daquelas questões de grandezas aparentes apontadas por Merleau-Ponty (2014). O espectador se vê perdido em meio ao seu tamanho real no espaço, a presença de uma imagem minimizada do seu corpo no monitor superior e a ausência de seu corpo no monitor inferior, que pela lógica da instalação também deveria estar ali, já que não há informações de que essa outra exibição é composta por imagens previamente gravadas. A problematização do espaço se dá então no entrelaçamento entre o espaço do quadro, da tela, e a experiência do espaço real que o espectador percorre.

Vemos ainda nesse conflito com a televisão dois polos de atuação entre os videoartistas quando do surgimento do vídeo. Por um lado, a vontade de estar na televisão, de utilizar o meio como uma forma de exibição de seus trabalhos. Por outro lado, artistas que abriram uma luta contra o controle da transmissão broadcast de TV, abordando politicamente os conteúdos da televisão e viram o vídeo como um meio alternativo para a construção de conteúdos mais experimentais.

Nesse primeiro âmbito de intervenções, podemos citar como exemplares, segundo Chris Meigh-Andrews, os casos de Gerry Schumm's e o programa de televisão Land Art (1969), que apresentou uma série de trabalhos experimentais de artistas como Richard Long e Robert Smithson; Robin Page e o programa Standing on My Own Head (1972), um desafio de interação televisiva com o público, que foi convidado por meio da programação televisiva para enviar para seus estúdios desenhos de representação do artista, além do programa holandês Visual 
Artists Make Video (1971), com a exibição na televisão de vídeos de vários artistas incluindo Bruce Nauman e Stanley Brouwn.

Jhon Wyver (2009) cita ainda outras ações no âmbito da programação televisiva, tais como Black Gate Cologue, exibido em 1968 na Alemanha pela rede de televisão WDR e considerado o primeiro programa de televisão feito por um artista; The medium is the message, uma compilação de 30 minutos de videoarte exibida em 1968 pela WGBH, sediada em Boston, em colaboração com o Center for Advanced Visual Studies do Massachusetts Institute of Technology, e com trabalhos de artistas como Peter Campus e Willian Wegman. Outro importante nome é o de David Hall, o qual trabalhou com intervenções na televisão britânica, discutiu a entrada dos vídeos nas galerias, e onde vemos uma clara relação entre cinema, televisão e videoarte, já que a maioria de seus trabalhos eram produzidos em $16 \mathrm{~mm}$, mas exibidos em vídeo na televisão. Para Hall a produção de vídeo tinha uma relação muito mais forte com o movimento conceitual das artes plásticas do que com as práticas televisivas ou cinematográficas.

Outra relação com a televisão pode ser claramente visualizada nos trabalhos de Nam June Paik $^{8}$, que interessam muito mais aos nossos estudos por apresentarem práticas que desencadeiam também espacializações. $\mathrm{O}$ artista foi um dos nomes pioneiros na criação de uma série de obras e intervenções que afetavam diretamente o aparelho televisivo, criando esculturas e intervindo no tubo magnético a partir de imãs, por exemplo, bem como na criação de sintetizadores próprios que problematizavam o conteúdo transmitido pelas televisões na época.

Apesar dos esforços de Nam June Paik no diálogo com a TV, artistas como Martha Rosle $^{9}$, segundo Meigh-Andrews, atacaram as atitudes de Nam June Paik por acreditar que a relação que Paik estabeleceu com a entrada dos mecanismos da televisão no campo da arte na verdade não problematizou em nada o caráter doméstico da mídia e seu conteúdo, promovendo uma sacralização deste no meio da arte, sem analisar, intervir ou tornar essa tecnologia acessível às possibilidades outras de criação para um público maior que pudesse se apropriar do meio, mantendo assim sua hegemonia cultural avassaladora para as grandes massas. Nesse mesmo movimento, segundo Chris Meigh-Andrews, para muitos artistas britânicos a televisão aparece como um verdadeiro oponente em função da alta tecnologia e alcance de público, que os

8 Nam June Paik foi uma figura pioneira na arte multimídia, trabalhou com rádio, televisão, robótica e computador. Nasceu em Seoul na Coréia em 1932 e estudou música e história da arte na Universidade de Tokyo, Universidade de Munich e na Academia de Música em Freibur. Possui trabalhos em acervos de vários museus ao redor do mundo, incluindo o Museu de Arte Moderna de Nova York, Museu de Arte Moderna de Paris d o Smithsonian American Art Museum. Fonte: www.tate.org.uk

9 Artista e crítica norte-americana nascida em 1943, trabalha com vídeo, texto, fotografia, instalação e performance. Fonte: www.marthaosler.net. 
trabalhos de videoarte dificilmente conseguiriam alcançar, demonstrando para esses artistas uma clara incompatibilidade de objetivos estéticos.

Apesar da crítica, Paik é inevitavelmente uma das principais referências quando falamos deste questionamento do conteúdo televisivo e da problematização escultural do aparelho de televisão, que aparece em obras como Nixon, concebida originalmente em 1965. Para o artista era importante a compreensão dos discursos veiculados na televisão e a intervenção sobre eles, principalmente na década de 1960, quando o governo dos Estados Unidos impunha uma série de regras que ditavam os conteúdos que poderiam ou não ser exibidos nesse meio. Em sua versão de Nixon datada de 2002 o artista propõe uma retomada e problematização das aparições do Presidente Richard Nixon, do seu discurso de posse, passando pelos seus posicionamentos sobre a Guerra do Vietnã, até o seu pronunciamento sobre escândalo de Watergate $^{10}$, que culminou na renúncia de seu mandato um ano depois.

Nessa obra, Paik apresenta esses conteúdos dispostos em dois monitores de TV colocados lado a lado sobre um gabinete branco com seis compartimentos abertos. Esses compartimentos abrigam um switcher ${ }^{11}$ de vídeo e sistema sonoro interligados a duas bobinas magnéticas que estão diretamente acopladas às telas dos monitores de TV. Enquanto os discursos do presidente Nixon são exibidos nos monitores as bobinas magnéticas se ocupam, a partir do sistema eletrônico criado, de executar distorções nessa tela, tanto no âmbito da imagem quanto do som.

Em primeiro lugar criam uma espécie de moldura circular (em função do formato circular das bobinas) que transformam a imagem, em alguns momentos, numa espécie de espiral que se esforça para surgir, mas que não tem força total para isso. Além disso, esse processo confere às imagens uma espécie de maleabilidade, como se quase se descolasse da tela do monitor, em que chegamos a ver um fundo preto resultado desse deslocamento, além de provocar certos saltos no tempo da imagem de acordo com a maneira como os elétrons dentro do tubo da TV respondem à carga magnética oferecida pelas bobinas. As linhas de varredura tornam-se ainda mais evidente e, se vistas normalmente na TV em um aspecto de linha reta, ganham uma forma serpenteada que se move pela tela levando a imagem também

10 Refere-se ao caso que veio à tona em 1972 nos Estados Unidos, quando se verificou que o presidente eleito Richard Nixon tinha conhecimento de operações ilegais de espionagem realizadas contra o Comitê Nacional Democrata. Em 1974 Nixon foi julgado e obrigado pela Suprema Corte dos Estados Unidos a renunciar ao cargo.

11 "Um processador de vídeo capaz de direcionar qualquer uma das suas entradas de câmeras para qualquer uma de suas saídas para o monitor, um nome usualmente reservado para sistemas de grande porte, de 16 a 128 , onde normalmente são incluidos controles de posicionamento e movimentação" Fonte: www.guiacftv.com.br 


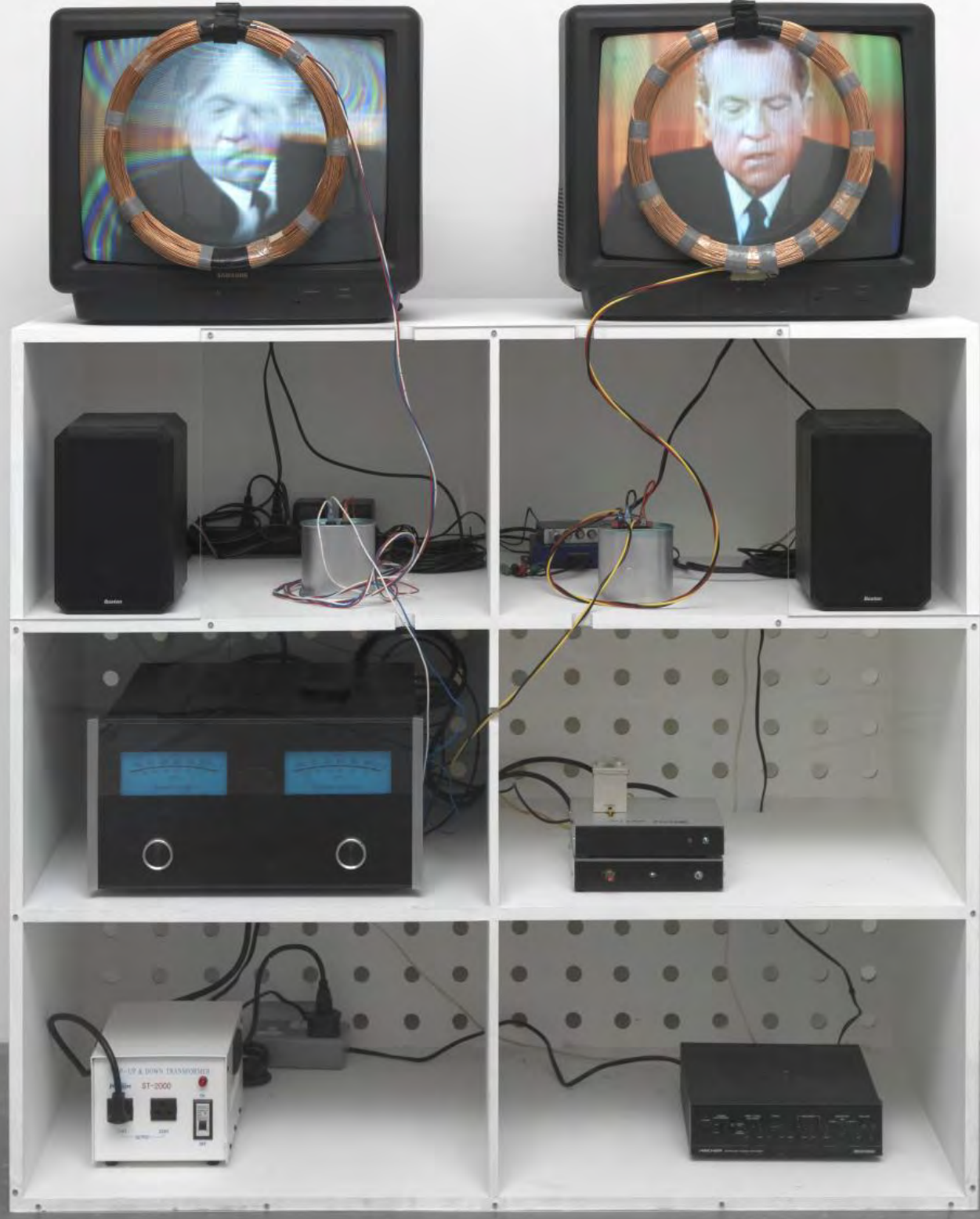

Ilustração 06: Nixon (1965-2002) de Nam June Paik em sua versão de 2002 na Tate Modern, Londres Fonte: www.tate.org.uk 
para posições diversas. Nesse processo o rosto de Nixon se transforma e suas palavras ganham uma sonoridade deformada, o discurso é transformado por meio da intervenção e da passagem da informação eletrônica..

Em um aspecto mais geral do trabalho, vemos também em alguns momentos uma situação de comparação entre o estado normal das telas e um estado alterado. Enquanto em um dos monitores não há ação sobre o conteúdo no outro as bobinas incorporam às imagens as distorções citadas. O posicionamento central dessas bobinas na tela de TV emoldura também a própria figura do presidente Nixon e dentro dessa circularidade vemos uma certa dualidade interna a cada monitor assim como acontece na relação entre monitores. Se por um lado o processo de magnetização desestabiliza a imagem, o formato circular a centraliza no quadro, a impressão que temos é que a imagem se movimenta o tempo inteiro pela busca de uma centralidade, que é emoldurada justamente pelas bobinas.

A imagem que se encontra dentro desse círculo tem bordas bem definidas, enquanto a continuação da imagem que extrapola o círculo delimitado atua no trabalho de dissolução das bordas da tela do monitor. As questões espaciais perpassam aqui, portanto, um jogo entre um movimento de centralização e ao mesmo tempo dissolução das bordas do quadro e, para além disso, o trabalho com o vídeo num âmbito tridimensional, na medida em que no aparelho de televisão os elementos eletrônicos que o constituem são trabalhados diretamente como ferramentas para a obra, o vídeo é tratado para além de seu aspecto de bidimensionalidade da tela e em aspecto de metalinguagem.

No que se refere ao cruzamento de aspectos de espacialização entre cinema e vídeo, o primeiro que devemos nos debruçar refere-se à diferença indicada por vários estudiosos, entre eles Phillipe Dubois e Arlindo Machado, quanto a espessura da imagem do vídeo como contraargumento da noção de profundidade de campo no cinema, esse último como a escala de planos integrada por elementos que vão do plano frontal ao plano de fundo, vislumbrando uma construção em perspectiva monocular a partir de um ponto de fuga, como nos trabalhos de pintura renascentista. $\mathrm{O}$ vídeo em caminho contrário torna essa espacialidade uma experiência de simultaneidade. Na imagem do vídeo mais de um assunto podem aparecer entrelaçados em um mesmo plano, de modo que o espetador precisa percorrer o espaço imagético de maneira as vezes frenética, algo como uma potencialização do scanning ${ }^{12}$ proposto por Vilém Flusser (2009), o que segundo Dubois (2004) configuraria uma espessura da imagem. Sobre essas questões Arlindo Machado (2007) que:

12 “(...) movimento de varredura que decifra uma situação” (FLUSSER, 2009, p. 78). 
Uma tendência que se verifica na prática generalizada do vídeo é a estrutura circular e reiterativa de sua forma sintagmática. Ao contrário do cinema moderno, que exige o concurso da sala escura como condição fundante do ilusionismo e que, em consequência disso, dirige todos os olhares para um único ponto luminoso do espaço - a tela onde são projetadas as imagens -, o vídeo em geral ocorre em espaços iluminados, em que o ambiente circundante concorre diretamente com o lugar simbólico da tela pequena, desviando a atenção do espectador e solicitando-o permanentemente, nesse sentido os meios eletrônicos retomam a tradição do primeiro cinema, tal como foi praticado nos vaudevilles (MACHADO,1997, p.198).

É importante, no entanto, delimitar historicamente a fala de Machado (década de 1990) para não cairmos no erro de achar que essas relações hoje se mantém de modo inabalável. Principalmente a partir do surgimento da projeção digital, o vídeo deixa de estar apenas na pequena tela, para se expandir para o espaço (o que já acontecia com as videowalls e instalações com monitores) e estabelecer outras relações, inclusive retomando as salas escuras para exibição em museus e uma certa linearidade narrativa. Michael Rush (2006) dá atenção especial às questões das novas narrativas que o vídeo apresenta. $\mathrm{O}$ autor explicita que assim como em diversas práticas artísticas, e inclusive no cinema, o vídeo também conta histórias, muito embora essas sejam contadas de uma maneira muito mais fragmentada do que as narrativas do cinema hollywoodiano, por exemplo. A preocupação narrativa desses artistas não é a da sequencialidade ou causalidade de fatos já posta por Jacques Aumont (2005), mas se atrela muito mais ao campo de um jogo entre o abstracionismo, minimalismo e conceitualismo.

Essas narrativas, no entanto, foram tomando outras formas ao longo do tempo e a partir da década de 1990 o video se desvincula de uma espacialização interna como prática fundante, retoma características da narratividade do cinema, e passa a se espacializar principalmente a partir do jogo de composição das telas em que o vídeo é digitalmente projetado. A diferença com os espaços das salas de cinema, apesar do resgate da narratividade, habita no fato de que o espectador aqui tem o livre arbítrio para entrar e sair da galeria a hora que quiser, o espectador vê o quanto de vídeo quiser, a partir de onde quiser, e termina também onde quiser. A narrativa que possui uma linearidade, que devia ser visualizada integralmente dificilmente é agregada à experiência do espectador de tal maneira. Nesses espaços, a duração de algumas propostas em video geralmente é maior e a quantidade de telas se multiplica, fazendo surgir uma infinidade de pontos de interesse que impulsionam e deixam o espectador mais a vontade para não se ater a apenas uma tela ou imagem. Esse tipo de trabalho está incluído no âmbito do que chamaremos no terceiro capítulo de uma situação-cinema na arte contemporânea, analisando alguns casos dessa prática de enfrentamento entre um retorno a uma certa narratividade do cinema e a multiplicação das telas. 
Retomando, no entanto, as espacializações possibilitadas por essas narrativas mais fragmentadas levantas por Rush, Dubois parte de três operações de composição, indicando a maneira como o vídeo discute essencialmente questões espaço-temporais que deslocam a prática da montagem tradicional, chegando ao que o autor chama de uma mixagem das imagens em vídeo. Para Dubois esse processo de mixagem torna-se um prenúncio das práticas instalativas pelas quais o vídeo vai se apropriar para compor sua expansão enquanto dispositivo. Segundo o autor:

\begin{abstract}
Se no vídeo ainda se monta, as imagens em todo caso são montadas uma sobre as outras (sobreimpressão), uma ao lado da outra (janela), umas nas outras (incrustação), mas sempre no interior do quadro. A montagem é integrada, ela é interior ao espaço do quadro. Assim, me parece possível opor, à ideia cinematográfica de montagem dos planos, o conceito mais videográfico de mixagem das imagens. (...) A mixagem das imagens permite enfatizar o princípio "vertical" da simultaneidade dos componentes. (DUBOIS, 2004, p. 89-90).
\end{abstract}

É importante elencar também como certos movimentos do cinema experimental / cinema de vanguarda apontam para uma relação que dialoga plasticamente com a linguagem do vídeo. Podemos citar os fluxfilms, os filmes de Marcel Duchamp, os rayogramas de Man ray, no entanto alguns movimentos específicos parecem ter uma questão de espacialidade que está muito mais ligada plasticamente com as práticas de videoarte que se seguiriam. É certo que muitas das características dessas práticas cinematográficas tem uma relação direta de trabalho com uma materialidade que é específica do cinema, a película. Queremos portanto, pontuar que o nosso esforço de análise está na comparação entre os produtos finais que resultam desse processo fílmico, compreendendo como algumas dessas metodologias que esses cineastas utilizaram foram também compartilhadas pelos artistas do vídeo em suas produções e embate com a linguagem eletrônica e digital para gerar vídeos que esteticamente se assemelham a essas abordagens anteriores, sem que necessariamente haja no trabalho desses videoartistas uma citação direta a essas ações experimentais no cinema. O principal desse diríamos ser o Cinema Estrutural $^{13}$, teorizado principalmente, segundo A. L. Rees (2011), por P. Adams Sitney ${ }^{14}$, o qual elencou características que seriam inerentes a esse cinema e que vemos estar na produção

13 Movimento no cinema surgido nos Estados Unidos a partir da década de 1960 e que encontrou reverberações no Reino Unido a partir da década de 1970 com a nomenclatura de Materialismo Estrutural. Alguns dos principais nomes desse movimento foram Michael Snow e Hollis Framptom, e tem no Reino Unido suas bases na London Filmakers Cooperative. Fonte: REES, A.L. A history of experimental film and video. Londres: Palgrave Macmillan, 2011.

14 Professor emérito do Lewis Center for The Arts da Princeton University (EUA) com foco de pesquisa em filme independente, experimental e de vanguarda. Autor de Visionary Film: The American Avant Garde, publicado em 1974. Fonte: www.arts.princeton.edu 
de vídeo à maneira da linguagem eletrônica ou digital, são elas: 1) A posição fixa da câmera; 2) O efeito "Flicker"; 3- Re-fotografia da tela e 4) A impressão de Loop. Nomes relevantes no contexto do Cinema Estrutural são os de Malcolm Grice ${ }^{15}$ e Peter Gidal ${ }^{16}$ que, no entanto, apresentam uma visão do cinema estrutural diferente da de P. Adms Sitney.

Segundo os autores, em comentário de Meigh-Andrews, o cinema estrutural é não ilusionista, busca desmitificar o processo de produção fílmica, e apresenta uma plasticidade materialista a partir do grão, da luz e do movimento como realidade apresentada. Já segundo Deke Dusinberre ${ }^{17}$, em relação à produção inglesa, "a estética do cinema estrutural apresenta o cinema como luz na tela evocando texturas, profundidade, imagem, ilusão potencial" (DUSINBERRE apud MEIGH-ANDREWS, 2014, pág. 96).

Essas características podem ser encontradas, por exemplo, em trabalhos como Berlin Horse (1970) e Threshold (1972) de Macolm Le Grice. Em ambos os filmes o artista trabalha com um jogo estrutural de cores que vão se diluindo umas nas outras e de certa maneira deformando e apresentando o personagem que visualizamos de modo diferenciado. No primeiro filme o artista se apropria de imagens de um cavalo que parecem ser geradas a partir de um negativo de película, conferindo uma tonalidade azulada e de certa maneira fantasmagórica. Ao longo do filme esse cavalo é mostrado andando a partir de movimentos circulares e repetitivos muito rápidos e em alguns momentos diluindo-se em meio a força da cor que é apresentada e a sobreimpressão de imagens desse mesmo cavalo em tonalidades diferentes, a qual vai com o tempo se alternando entre o vermelho, o laranja, o verde, para no final visualizarmos um esquema de cores que se diluem umas nas outras a partir das cores supracitadas.

Em alguns momentos do vídeo as imagens do cavalo se diluem de tal forma à alta saturação das cores que sequer conseguimos identificar sua presença, conferindo à imagem uma potencialidade a partir dessas texturas e cores geradas. Ainda no final do vídeo voltamos a reconhecer a figura de um cavalo em um lugar que parece estar em meio a um incêndio, reconhecendo também outros cavalos e personagens humanos que parecem retirá-los desse lugar de perigo, dialogando ainda com a fumaça que se espalha e confere outra plasticidade no jogo com a cores quentes e com a alternância entre positivo e negativo da película, que são

\footnotetext{
${ }^{15}$ Estudou pintura na Slade School of Fine Art, University College London, começando sua carreira em 1960 e produzindo vídeos filmes e trabalhos de arte computacional. Tem trabalhos teóricos nessa mesma área, com destaque para a publicação "Abstract Film and Beyond" (Studio Vista e MIT, 1977). Atualmente é professor na Central St. Martins, University of the Arts London. Fonte: www.malcomlegrice.com.

16 Cineasta experimental nascido em 1946, estudou teatro, psicologia e literatura na Brandeis Univerity, Massachusets. Foi professor de Film Theory no Royal College of Art, Londres, de 1971 a 1984. Autor da publicação "Structural Film Anthology" (Britsh Film Intitute, 1978) Fontes: www.mitpress.mit.edu / www.ubu.com.

17 Dusinberre escreve sobre essas questões no ensaio intitulado "Structural Asceticism" publicado em 1976.
} 
visualizadas e parecem se referir a essa situação de incêndio. Esse segundo segmento do filme é, segundo Symon Payne (2016) advindo do filme The Burning Stable (1896), realizado pela Edison Manufacturing Company. Importante citar que esse filme também foi apresentado em uma versão de duas telas, sendo uma delas composta pela peça que acabamos de descrever, modificada, e outra pela gravação original que serviu como matéria-prima para os procedimentos de colorização e modificação temporal da primeira.

Já Thershold (1972) se inicia com a alternância de manchas verdes, vermelhas e amarelas durante aproximadamente sete minutos, momento em que começamos a visualizar uma série de guardas em uma região de fronteira de áreas militares constituídos pelas cores acima e alternados ou sobrepostos entre si e formas circulares animadas que se expandem e contraem na imagem. Ao evidenciar questões de fronteira, Malcom integra uma discussão acerca das transformações que essa passagem entre lugares confere, seja no âmbito social ou pelas experiências entre linguagens e pelo processo de composição e diálogo entre cores, elemento fundamental na prática do artista. De acordo com Payne esse trabalho foi exibido em formato de performance com três telas diferentes a partir do jogo ao vivo com o movimento dos equipamentos que projetavam as imagens com os elementos supracitados mas existe também em formato para uma tela.

Além dessas questões postas no trabalho de Malcom Le Grice, o cinema estrutural evoca questões relacionadas a duração, provoca um certo tédio e reforça os aspectos sensoriais, que forçam o espectador a um confronto de tempo e espaço com a imagem cinematográfica. Dentro do movimento do cinema estrutural Dusinberre elenca ainda as práticas dos landscape films, filmes que trabalhavam com a captura de imagens de paisagens, tornando-as quase abstratas em função da velocidade de corte e close-ups. Podemos citar como exemplo a produção de Chris Welsby ${ }^{18}$, que em trabalhos como Fforest bay two (1973), compõe a partir de imagens de paisagens diversas exibidas em alta velocidade, evitando pontos de vista panorâmicos, dando ênfase aos detalhes e posicionando a câmera em ângulos diferenciados ( $45^{\circ}$ no trabalho citado).

18 Nasceu em 1948 em Exeter na Inglaterra. Formou-se em Fine Art pela Chelsea School of Art, Londres, em 1973 e atualmente é professor na School for the Contemporary Arts da Simon Fraser University, em Vancouver - Canadá. Seus trabalhos tem sido exibidos em importantes espaços como a Tate Modern e a GALERIA Hayward em Londres, Museu do Louvre e Centro George Pompidou em Paris, Museu de Arte Modern de Nova York e a Art Gallery of Ontario em Toronto. Fonte: www. Sfu.ca/welsby 


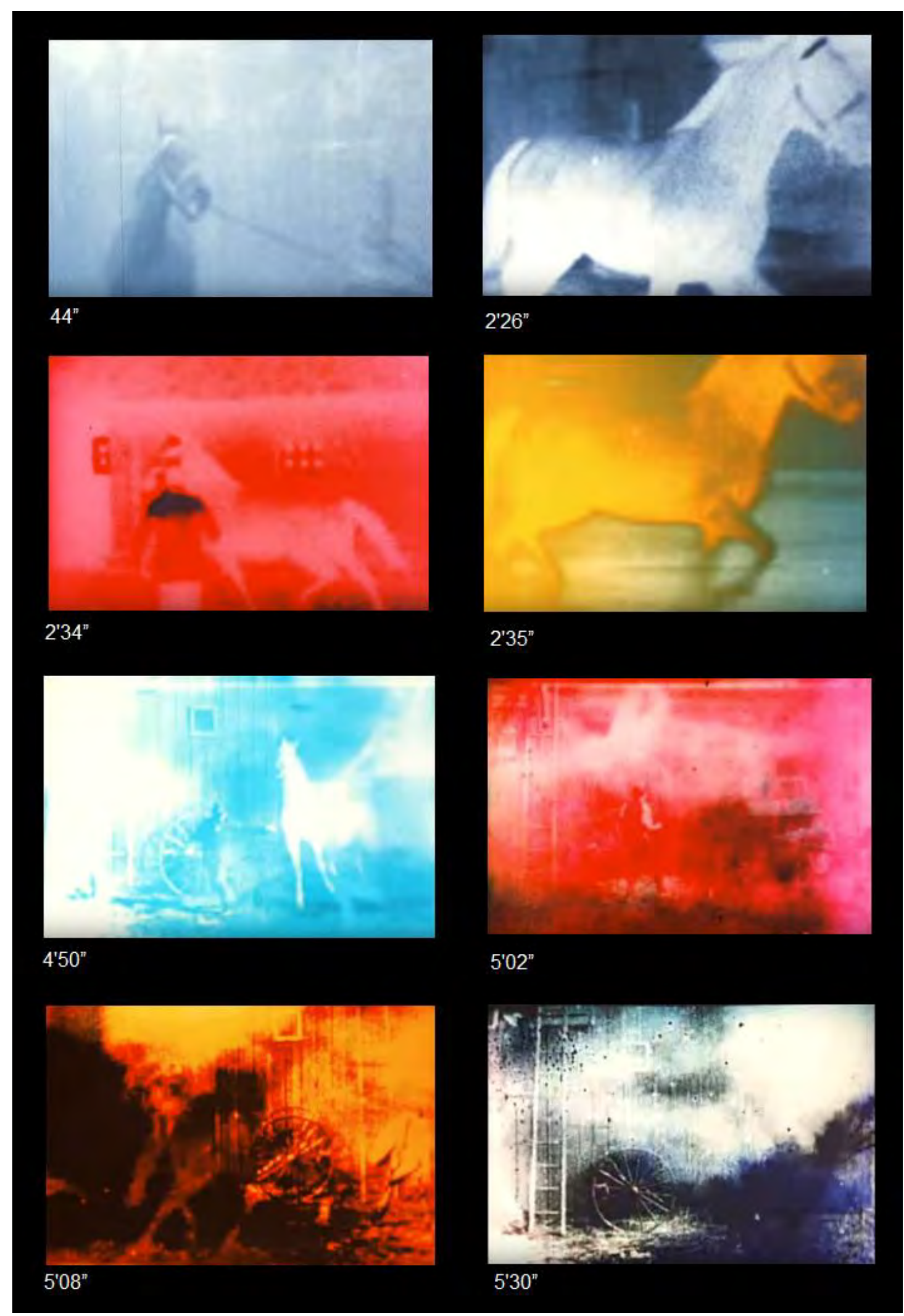

Ilustração 07: Frames de versão em vídeo online do filme Berlin Horse (1970) de Malcolm Legrice Fonte: www.lux.org. uk 


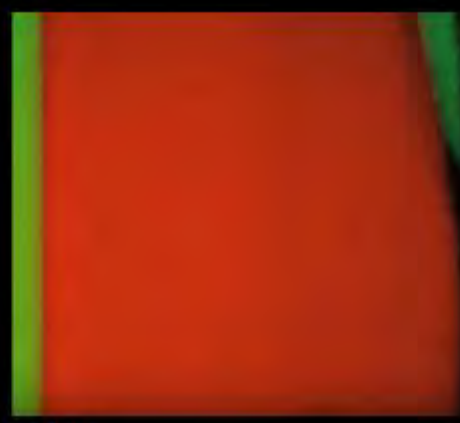

$5^{\prime} 53^{\prime \prime}$

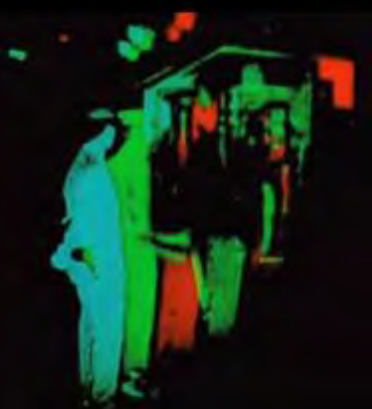

$8^{\prime} 52^{\prime \prime}$

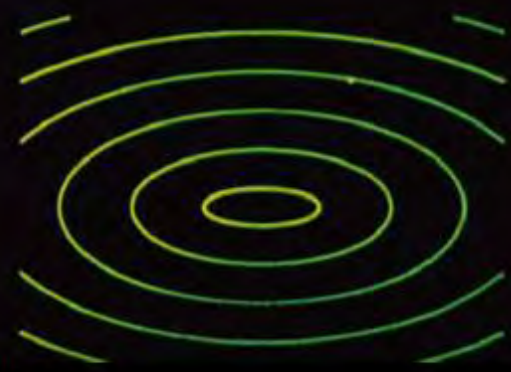

$10^{\prime} 54^{\prime \prime}$
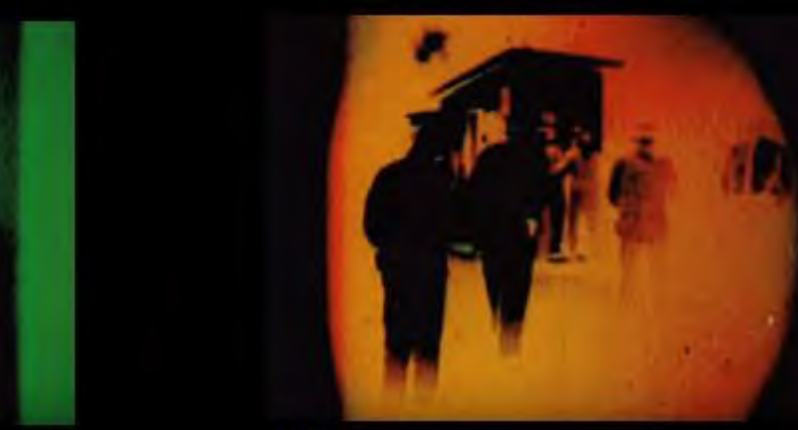

$7^{\prime} 15^{\prime \prime}$

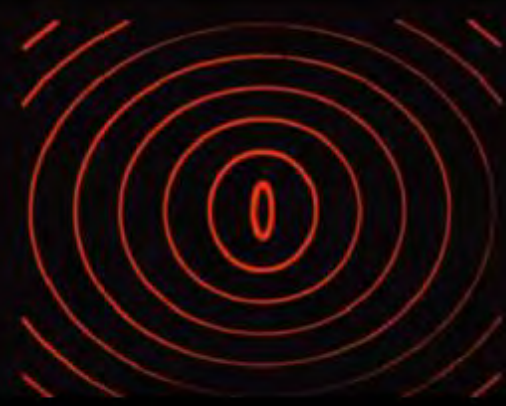

$10^{\prime} 21^{\prime \prime}$

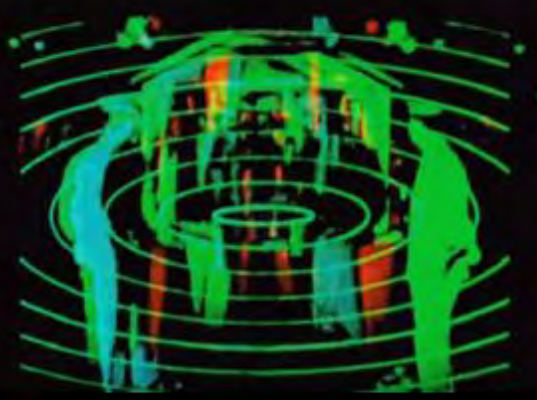

$10^{\prime} 56^{\prime \prime}$

Ilustração 08: Frames da versão em vídeo online do filme Threshold (1972) de Malcolm Le Grice Fonte: www.lux.org..uk 
Embora não se foquem especificamente em questões de apresentação de paisagens naturais, alguns artistas contemporâneos se apropriam desses mecanismos para falar de lugares pelo qual passaram, quase um diário de viagem apresentado em vídeo de modo semelhante ao que Chris Welsby produziu. Um exemplo para nós é o vídeo Ali é um lugar que eu não conheço (1996) de Lucas Bambozzi ${ }^{19}$. Nesse trabalho Bambozzi realiza uma coletânea de videopoemas experimentais que de acordo com o artista versam sobre relações de encontros, pessoas, lugares e o fascínio pelo desconhecido.

O vídeo é composto por uma série de imagens que lembram filmagens feitas em película e inicia com gravações de uma estrada de dentro de um automóvel em movimento. Em seguida vemos uma série de imagens de paisagens urbanas, uma série de prédios e pessoas caminhando por interiores diversos. O título do vídeo aparece então sobre um caderno em branco que se paralisa por alguns segundos até a retomada do movimento de cortes frenéticos, onde apenas um pé aparece caminhando sobre alguns pedregulhos, passando enfim para imagens de uma mulher de costa, que são sobrepostas sobre tomadas de estradas. Enquanto essas imagens são visualizadas, os versos desse vídeo poema aparecem na parte inferior do quadro, tais como "Ela é a viagem”, “Impossível não ir”, "Impossível não chegar”, “Que nos dá experiência?”, "Tantas imagens, possíveis vertigens!”, “Ali pode ser a certeza”, “Ali pode ser um lugar que não conheço". O vídeo conclui-se na relação de movimentos ainda muito rápidos em que uma mão aparece seguindo alguém que está à frente e finalizado por uma espécie de despedida de um casal e uma mão apontando para um horizonte. O ritmo das imagens traz à tona essa perspectiva de dissolução dos personagens em suas histórias de busca em lugares, em pessoas, relações e os encontros possíveis que podem surgir disso.

De modo um pouco mais anárquico no jogo com a velocidade da imagem, mas em uma perspectiva muito parecida com a de Bambozzi, Dirceu Maués ${ }^{20}$ em City Tour (2008) apresenta uma sequência do caos da cidade, da desorganização do espaço, da fragmentação, o que relega

19 É artista e pesquisador em novos meios. Trabalha com vídeo, instalação, performances audiovisuais e projetos interativos que exploram questões do universo dos dispositivos de registro e manipulação da imagem. É mestre em Filosofia pela School of Computing, University of Plymouth, Reino Unido. 2006, doutorando na Faculdade de Arquitetura e Urbanismo (FAU-USP), São Paulo, e professor do curso de Artes Visuais da FAAP, na mesma cidade. Participou de exposições em países como Argentina, Espanha, Estados Unidos, Polônia, Brasil e Reino Unido. Fonte: www.videobrasil.org.br

20 "Fotógrafo desde 1991, atuou como instrutor na Fundação Curro Velho, na década de 1990, em Belém (Brasil). Trabalhou como repórter fotográfico nos grandes jornais impressos de Belém durante 12 anos. Atualmente é o responsável técnico pelo laboratório fotográfico da Universidade Paulista - unidade Brasília (UNIP Brasília) e é estudante de graduação do curso de Artes Plásticas n Universidade de Brasília (UnB). Seus trabalhos fazem parte das coleções Pirelli-Masp, FNAC, Videobrasil, Museu de Arte Contemporânea do Paraná, Museu de Arte Contemporânea de Ribeirão Preto, Museu Histórico do Estado do Pará e Coleção Joaquim Paiva." Fonte: www.videobrasil.org.br 


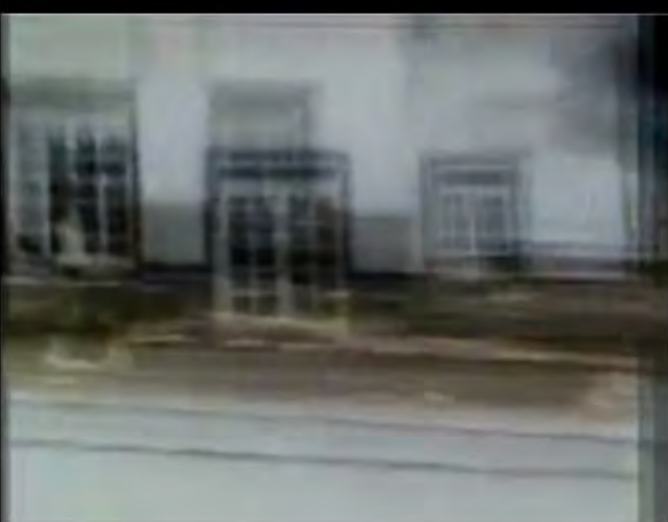

$12^{n}$

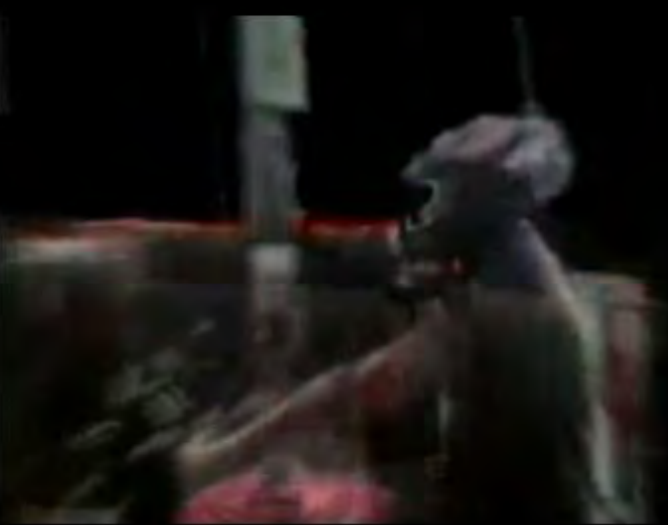

$1^{1} 32^{\prime \prime}$

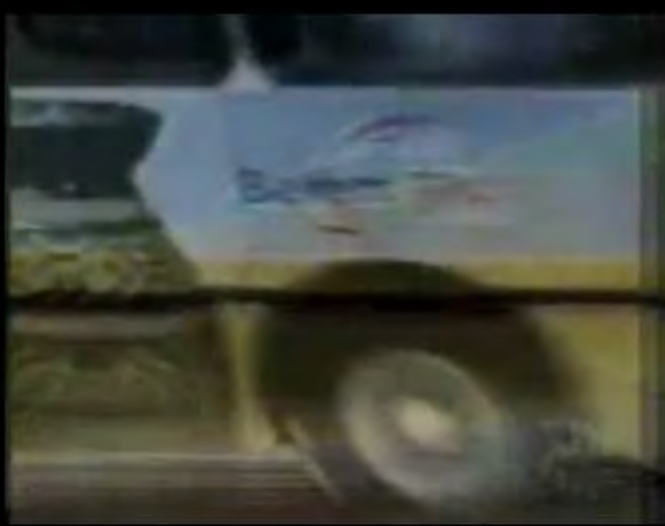

$2^{\prime} 22^{n}$
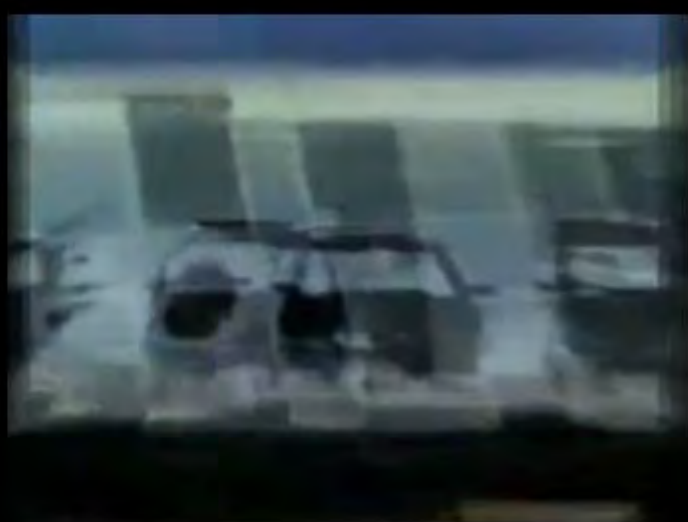

$41^{m}$

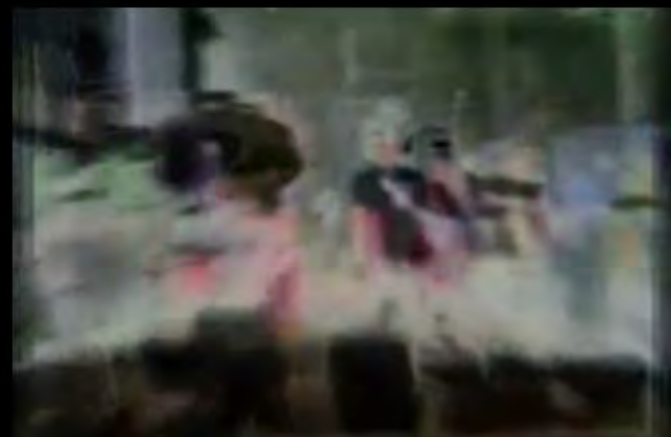

$2^{\prime} 17^{\prime \prime}$

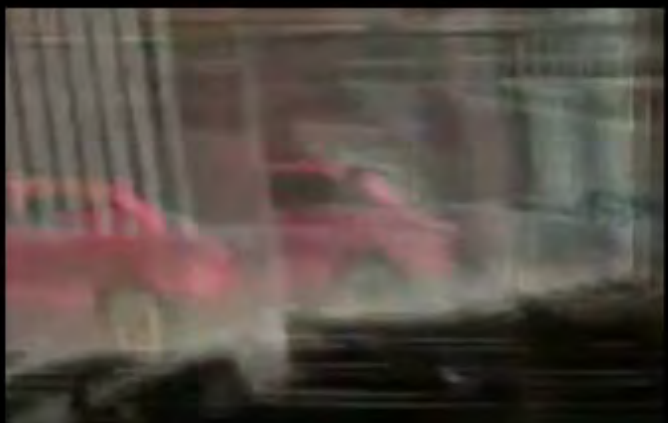

$2^{\prime} 38^{\prime \prime}$

Ilustração 09: Frames do vídeo City Tour (2008), de Dirceu Maués

Fonte: Acervo do projeto de pesquisa "Acervo de Videoarte paraense: sistematização e análise crítica" (CNPq/SEC/MinC - 2014-2016). 
essas imagens, que metaforizam o ritmo da cidade, a um estado de quase não reconhecimento dos elementos que compõe esse espaço urbano que está sendo gravado.

As cores, formas e texturas se sobressaem à representações figurativas, embora entremeadas por carros, árvores, pessoas que aparecem e desaparecem do quadro em alta velocidade e que são reforçados por um áudio contínuo de ruídos urbanos cotidianos. Ambos os trabalhos citados diluem o espaço no tempo acelerado do movimento em que as imagens são apresentadas no quadro, onde o corte rápido e as sobreposições constantes na transição entre imagens trazem uma relação pictórica que acaba se sobressaindo (principalmente no trabalho de Dirceu Maués, assim como nos filmes de Le Grice). As questões de espacialidade nesses trabalhos parecem, num sentido contrário aos trabalhos de Luciana Magno e Danillo Barata por exemplo, evocar uma atenção inteira para o interior do quadro. A velocidade da imagem sequer nos deixa desviar atenção ou construir um processo imaginativo que nos levaria de imediato, no tempo do vídeo, para outros eixos espaciais que não o delimitado pelas bordas dessas imagens.

Nessa mesma linha de um cinema experimental, outra abordagem que nos parece ter uma relação plástica e espacial com as práticas contemporâneas de videoarte é o que Chris Meigh-Andrews localiza nos estudos de Malcom Le Grice como Abstract Film. Segundo o autor, as três características principais desse tipo de produção são: a separação de um objeto de seu contexto habitual a partir de close-ups, rápidas movimentações, e ângulos de câmeras não usuais; a montagem das imagens baseadas em semelhanças visuais ou de movimento e técnicas como a utilização e exposição direta de fotogramas alterados. Essas características do cinema estrutural e do cinema abstrato, que para nós muito se relacionam e complementam numa discussão de espacialidade e narrativa fragmentada, são de algum modo encontradas nas práticas de videoarte, parcela dessa produção se baseando nesse princípio de deformação que acopla essas questões.

Em Vermelho (2007), por exemplo, Melissa Barbery apresenta um inseto que se desloca no espaço do quadro deixando rastros de um líquido vermelho. A proximidade da câmera e a imagem difusa nos permitem reconhecer o inseto, mas nos distancia do que pode ser aquele ambiente o qual ele percorre. Ao longo do vídeo esses rastros deixados vão aos poucos preenchendo o quadro, efetuando uma ação de pintura a partir da caminhada do animal. Ao fundo dessas manchas e traços que visualizamos uma luz ilumina esse quadro e ao mesmo tempo um áudio com suspiros e sons de um monitor de batimentos cardíacos aparece.

$\mathrm{O}$ inseto ali parece agonizar no trabalho de pintura daquela superfície tomada pela cor vermelha, que inevitavelmente na relação com o áudio nos remete a sangue e morte. A cor 


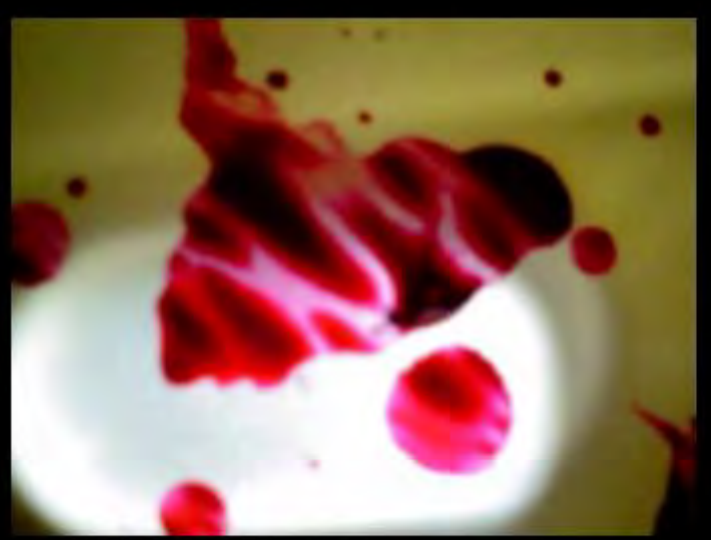

$01^{n}$

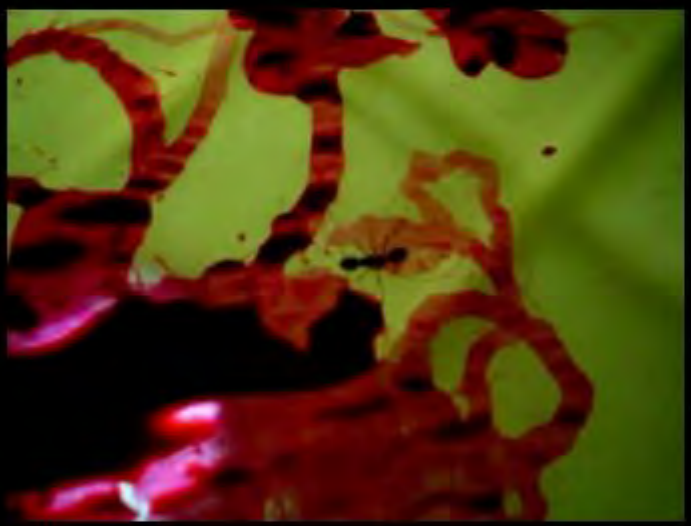

$43^{n}$

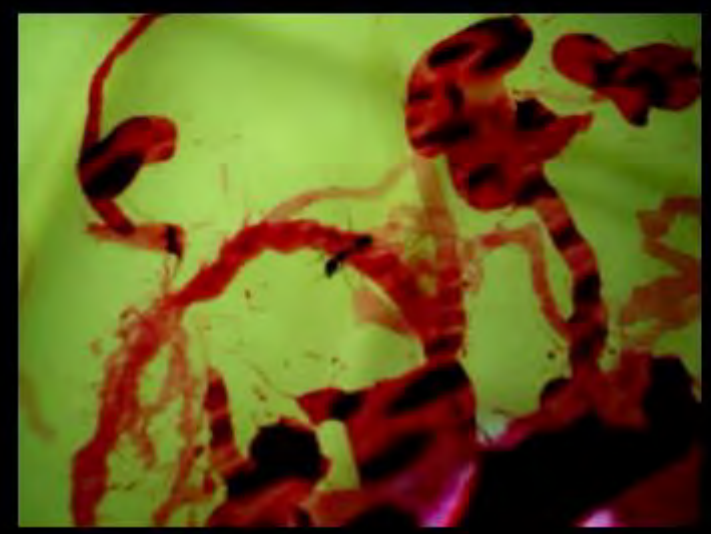

$1^{\prime 2} 21^{\prime \prime}$

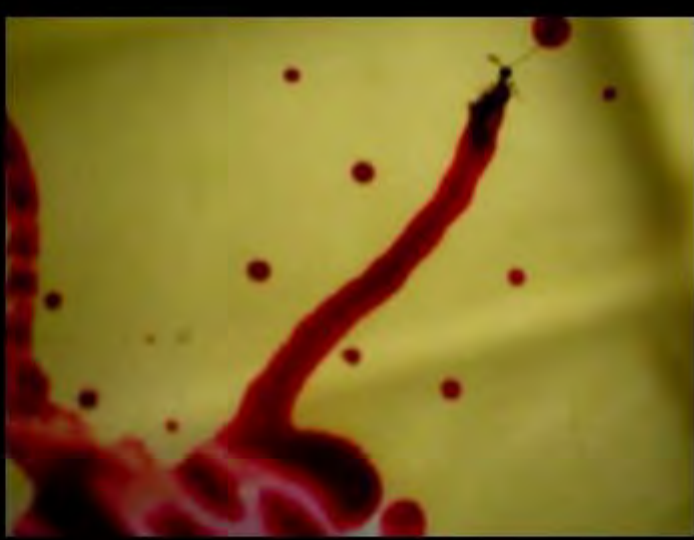

$08^{\mathrm{n}}$

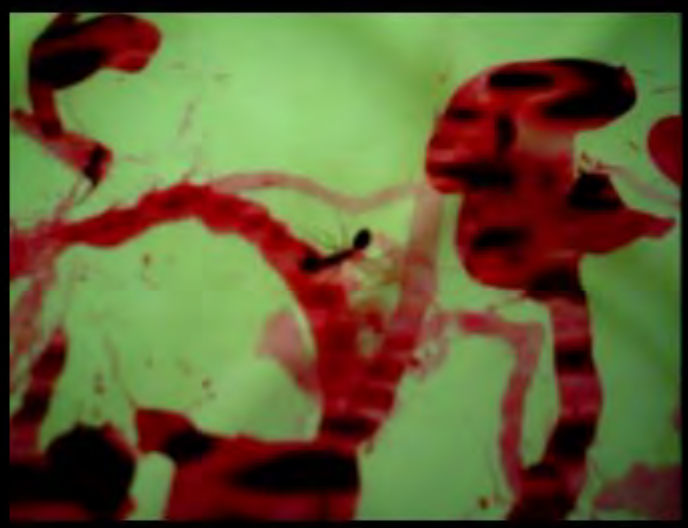

$1^{\prime} 08^{n}$

\section{verme}

Ilustração 10: Frames do vídeo Vermelho (2007), de Melissa Barbery

Fonte: Acervo do projeto de pesquisa "Acervo de Videoarte paraense: sistematização e análise crítica" (CNPq/SEC/MinC - 2014-2016). 
vermelha, que nomeia o vídeo é elemento fundamental de pictorialidade do trabalho, e segundo a artista "a palavra (...) tem sua origem no latim vermillus, que significa 'pequeno verme', remetendo-se à cochonilha - inseto - ser - do qual é extraído o corante carmin utilizado em tintas, cosméticos e como aditivo alimentar" (BARBERY, 2012, p. 57). A questão pictórica do vídeo trata então da própria existência em seu teor filosófico, a partir da relação com o inseto que, se possível produtor daquela cor, é também a partir dela que encontra barreiras, já que vemos uma certa dificuldade de locomoção deste ao esbarrar com a materialidade vermelha em seu caminho. A artista no final do vídeo ainda joga com a relação entre as palavras "verme", que aparece primeiro sozinha na tela, e "vermelho" que surge a partir da anterior, completandoa com o sufixo "lho". Processos parecidos de ênfase numa pictorialidade aparecem também em trabalhos como Alegoria (2012) do Coletivo Madeirista ${ }^{21}$ e Omolu não é São Lázaro (2003) de Flávio Lopes ${ }^{22}$.

No primeiro vídeo os artistas apresentam uma série de focos de luz coloridos que se movimentam pela tela intercalados com algumas linhas que parecem ser as próprias linhas de varredura do vídeo, tornando a imagem basicamente uma sucessão de elementos formais básicos e acompanhado de sonoridades que seguem o fluxo de aparecimento dos focos de luz e incluem sons de batuques quando do aparecimento das citadas linhas. Não há indicação no próprio vídeo da proveniência das imagens, mas o contato com textos dos artistas nos revela que essas foram gravadas a partir de um desfile de escola de samba. O vídeo é uma tentativa de retomada das características imagéticas das visões xamânicas que surgem no ser humano quando do consumo de uma substância psicotrópica chamada peiote. Na sinopse os artistas do trabalho citam como essas visões são descritas a partir de formas ovoides assim como visualizamos no vídeo.

Já em Omolu não é São Lázaro (2003) Flávio Lopes discute questões referentes às estratégias de resistência da cultura africana no Brasil a partir de um processo de sincretismo, partindo de elementos da cultura cristã para metaforizar essa relação. O vídeo se inicia com uma tomada em plano geral de uma igreja católica com luzes que contornam as formas de sua arquitetura (janelas, portas, paredes) onde vemos também um importante símbolo, a cruz.

21 "Grupo formado por artistas e pensadores que se reúnem desde 2001 para produzir e discutir arte contemporânea, literatura e poesia. Sediados em Porto Velho, suas publicações, net.art, poesia visual, performances, intervenções urbanas e videoarte refletem sobre o estatuto da arte na sociedade contemporânea. Participaram da mostra Não seja Bienal, Não seja Marginal, Casa da Xiclet, São Paulo (2012). Todos os participantes vivem e trabalham em Porto Velho." Fonte: www.videobrasil.org.br

22 'Vive e trabalha na Bahia. Produz vídeo desde 2002. Em 2005, foi curador do I Circuito de Arte Eletrônica da Bahia - Empuxo. Já trabalhou com entalhe em madeira, joalheria, gravura, teatro e cenografia, cursou filosofia e fundou o ateliê coletivo Casa de Nômades, dedicado à estamparia.' Fonte: www.videobrasil.org.br. 


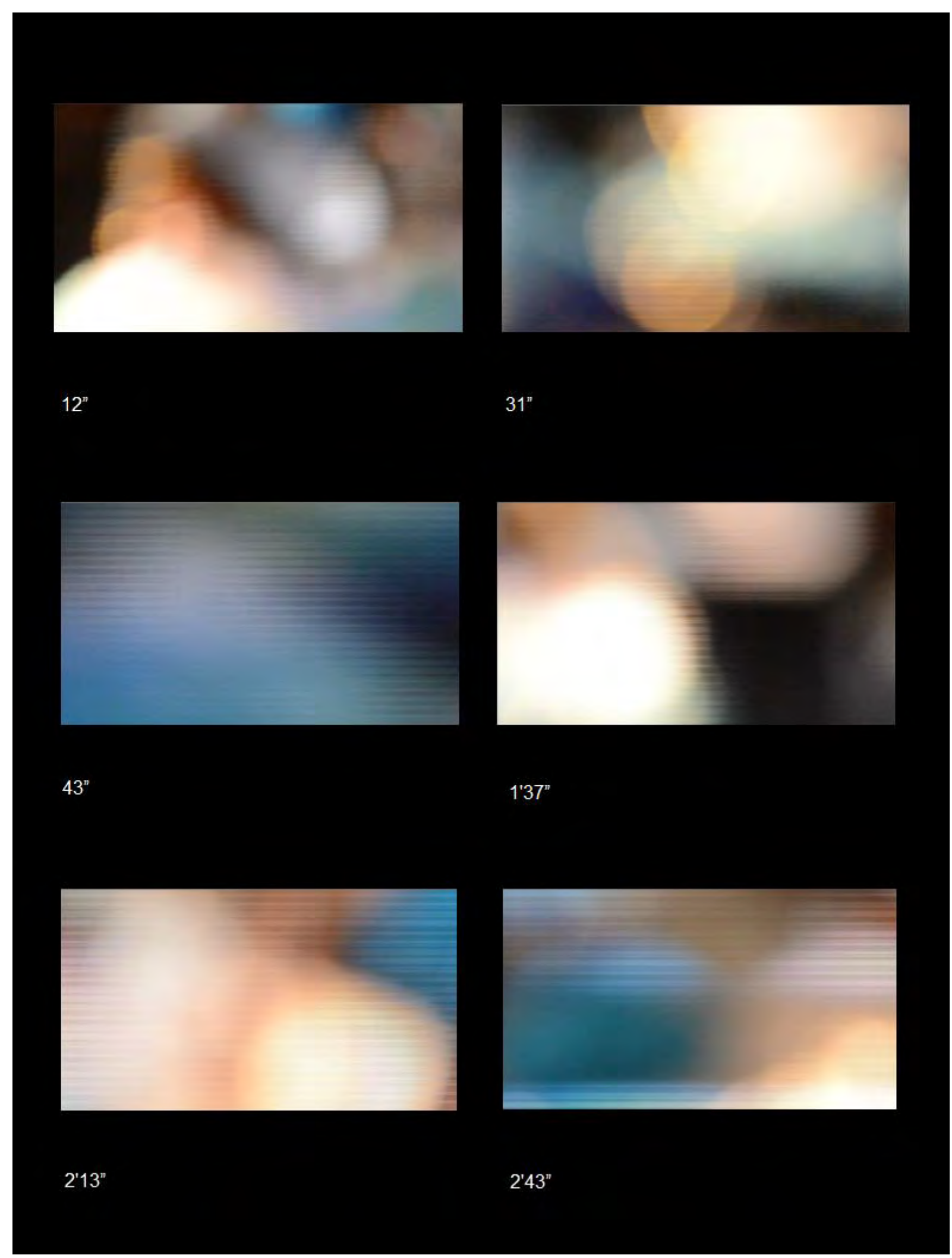

Ilustração 11: Frames do vídeo Alegoria (2012) do Coletivo Madeirista Fonte: Acervo da Associação Cultural Videobrasil 
Nos segundos seguintes um movimento de zoom aproxima a imagem dessa igreja e os agora movimentos desequilibrados da câmera começam a deformar a imagem dessa arquitetura, evidenciando rastros de luz que surgem no quadro a partir da iluminação da igreja, distanciando-a de um figurativismo e deformando seus símbolos para levá-los ao estado de simplesmente luz em movimento. Ao longo do vídeo esses rastros de luz são isolados a partir de processos de edição e apresentados de maneira repetitiva e em série. Aqui os artistas utilizam, portanto, movimento rápido da câmera, repetição e isolamento desses elementos do contexto original para a formação dessas imagens abstratas em que imperam as cores e as formas. Esses procedimentos são acompanhados ao longo do vídeo inteiro por um cântico de matriz africana sobre $\mathrm{Omolu}^{23}$, em uma relação muito parecida com os videoclipes, em que ganchos da música afetam o estado e movimento da imagem. O vídeo finaliza com um retorno à imagem original da igreja apresentada no início a partir de uma estabilização dos movimentos da câmera e zoom out.

Nessa mesma perspectiva, Márcia Vaitsman ${ }^{24}$ em Estudo sobre a escuridão (2009) falará sobre a interposição do Rio São Francisco metaforizada a partir de um processo de edição que apresenta as sutilezas da paisagem que o circunda durante a escuridão da noite. Como já evidenciado no título do trabalho a artista se utiliza desse elemento escuridão para de certa maneira mascarar o ambiente que está sendo gravado e, dessa maneira, todos os pontos de luz que surgem na imagem aparecem como elementos descontextualizados pela escuridão e nos causam uma sensação de flutuação e perda da referência do espaço original. O vídeo é dividido em três segmentos. No primeiro, intitulado Study \#1: approaching darkness, vemos inicialmente uma paisagem com rio ao anoitecer que se transforma logo em seguida apenas em uma linha do horizonte que se duplica e dissolve horizontalmente nela mesma durante algum tempo, fazendo a representação dessa linha do horizonte se transformar em uma série de manchas de uma paleta de cores do anoitecer. Em seguida a imagem escurece completamente e três esferas brancas surgem na tela se movimentando sutilmente na escuridão para dar lugar a imagens com nuances entre o preto, o cinza e o branco e que revelam silhuetas humanas em algum local que não podemos identificar.

23 Orixá de religiões de matriz africana.

24 "Formada pela Escola de Comunicações e Artes da Universidade de São Paulo, estudou na KHM (Kunsthochschule fur Medien Koln) de Colônia, Alemanha. Foi professora na mesma instituição entre 2001 e 2007. Suas obras tratam de questões suscitadas pelos fenômenos de migração, deslocamento e miscigenação, e seus desdobramentos frente às mídias contemporâneas. Expôs na Europa, Américas e Ásia” Fonte: www.videobrasil.org.br 


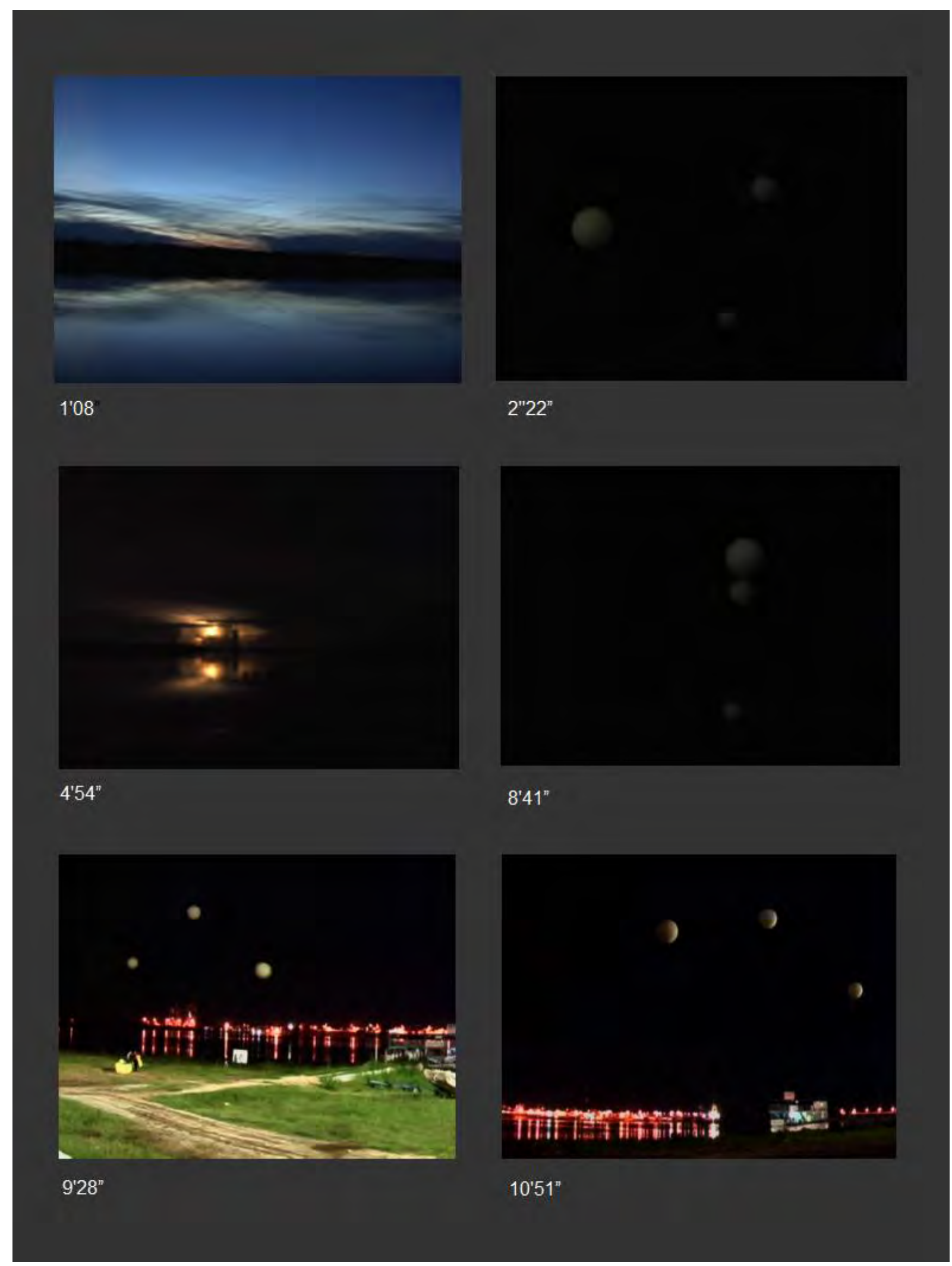

Ilustração 12: Frames do vídeo Estudo sobre a escuridão (2009) de Márcia Vaitsman Fonte: Acervo da Associação Cultural Videobrasil 
O segundo segmento, Study \# 2: artificiality in darkness, começa com uma escuridão logo interrompida pelo surgimento de uma série de focos de luz que por um lado se apresentam em sua autonomia de elemento na escuridão e, por outro, nos fazem identificar a presença de uma outra linha do horizonte da paisagem do Rio São Francisco. Os focos de luz aqui aparecem para nós muito mais em uma busca pela primeira possibilidade, de abstração do espaço representacional em detrimento da apresentação desse. O som nesse segmento toma um rumo importante na medida em que seus pontos mais altos, uma espécie de batuque de tambor que surge em alguns momentos, é quem anunciam também a aparição momentânea desses focos de luz. Durante todo esse momento uma voz parece proferir um cântico que, por sua vez, antecipa tanto os focos de luz quanto o próprio barulho do tambor.

No terceiro e último segmento, intitulado Study \# 3: replacement, as mesmas esferas brancas do primeiro segmento voltam a aparecer em movimento na tela escura e se juntam às imagens dos focos de luz do segundo segmento. A partir desse momento passamos a reconhecer então do que se tratavam cada um daqueles elementos anteriormente descontextualizados, as esferas (balões), os focos de luz (luzes de uma pequena cidade) e as silhuetas humanas que aparecem no primeiro segmento (pessoas na beira do rio). Vaitsman apresenta, desse modo, um importante processo de desconstrução e reconstrução do espaço do quadro a partir da segregação e apresentação separada dos elementos que compõem o espaço da paisagem noturna do Rio São Francisco, que retoma sua forma e nos é apresentado em sua totalidade figurativa.

Todos esses últimos vídeos comentados usam o desfoque, o close-up e os movimentos rápidos de câmera para acentuar as questões pictóricas do quadro e os elementos individuais que o constitui, algo já encontrado em parte no trabalho de Dirceu Maués citado anteriormente. A diferença é que trabalhos como Alegoria, por exemplo, se quer nos dão pistas do material original que foi modificado, enquanto outros como Omolu não é São Lázaro e Estudo sobre a escuridão trabalham no jogo da apresentação de uma realidade figurativa, deformação dessa e retorno ao estado inicial.

Embora questões de diluição de espacialidades não sejam tão marcantes no interior do quadro, essa linha de trabalho, que aqui são apresentados em mono-canal, serão uma forte tendência nas apresentações de instalações que constroem ambientes a serem percorridos, onde a discussão de espacialização reside muito mais nessa relação entre a bidimensionalidade da imagem do vídeo e o espaço tridimensional e habitável da galeria, questões que discutiremos no terceiro capítulo a partir da apresentação de outras obras.

Assim, procuramos aqui indicar alguns elementos poéticos que a produção em vídeoarte e a produção em película que alguns movimentos do cinema, como o cinema estrutural e o 
cinema abstrato, compartilham. Erika Balsom (2013) acredita que artistas que trabalham com o filme e o vídeo ao mesmo tempo em geral realizam trabalhos como esses citados, que fogem de um ilusionismo e costumam estabelecer relações muito mais profundas com outras mídias que não as da imagem em movimento. Isso traria à tona, principalmente para o vídeo, características que o diferem de outras mídias por, de um lado, relacionar-se com as artes plásticas de uma maneira muito mais aberta e, por outro, manter certas características de conteúdo e forma que antes eram específicos do cinema, criando nos espaços de museus e galerias o que a autora chama de uma nova estética cinemática no vídeo. Balsom acredita que essa nova estética atua como um vetor de "exposição" do cinema, assim como problematiza Dubois (2004), no sentido de fazer emergir de maneira aberta e consciente para o público os elementos que compõem a experiência cinematrográfica de maneira fragmentada, principalmente nos espaços de vídeoinstalações.

Seguindo esses desdobramentos, no final das décadas de 1980 e começo de 1990, vimos o aparecimento dos processos de edição digital no computador a partir de sofisticados softwares como Macromedia's Video Works (1985), Director (1987), Final Cut Pro (1998), Adobre Premiere (1991) e Adobe After Effects (1993), introduzidos no mercado para facilitar e democratizar o trabalho do videomaker. Esse agora poderia trabalhar em seus computadores em estúdio próprio com refinado processo de edição e com um custo bem menor do que aquele refletido pela utilização das máquinas de grandes empresas de televisão, e que reverberam na apresentação desses elementos recorrentes nos trabalhos citados anteriormente a partir de ferramentas digitais.

O computador e suas ferramentas de software tornam-se, portanto, vetor fundamental para uma mudança radical na prática de se produzir vídeos. Para Christiane Paul (2015), a autonomia desse processo digital reside no fato de ser produzida e apresentada dentro desse parâmetro sem necessidade de um acoplamento a outras vertentes para sua existência, o que claro não necessariamente nega essas outras relações. Um computador pode ser o criador de imagens em movimento por meio de códigos numéricos, sem a necessidade de uma câmera, e pode ele mesmo exibi-lo por meio de sua tela, algo como o que os sintetizadores fizeram no surgimento da videoarte. Segundo a autora algumas das características principais das práticas artísticas que se focam nesse percurso do digital seriam: 1) interatividade: diferentes formas de navegação que contribuem para a modificação do estado inicial do trabalho; 2) participação: aciona a participação física do fruidor com os parâmetros criados pelo computador; 3) dinamismo: mudam de forma de acordo com a interação e 4) customização: apresentados em uma série de possibilidades de materialização de acordo com a ação de cada participante. Esses 
trabalhos podem ser apresentados em uma variedade de formatos, como nas instalações interativas, realidade virtual, softwares produzidos por artistas, webart ou combinações entre essas manifestações. A possibilidade de navegação nesses ambientes digitais só é possível a partir de uma interface que processará dada informação de interação, com a qual o participante entrará em contato, e uma dessas pode ser a tela, constituída de sinal de video.

Christiane Paul lembra-nos que grande parte dos trabalhos de arte digital são na verdade uma variação e reminiscência das videoinstalações de grandes proporções, utilizando um número variado de telas e projeções ou dos trabalhos de videovigilância que incluíam de alguma maneira o público na gravação de vídeo em tempo presente, constituindo bases para os processos interativos proporcionados pelo advento da tecnologia digital. Paul (2015) elenca as principais características desses trabalhos em que o vídeo aparece como mídia de atravessamento por meio da linguagem digital: "modelos arquiteturais; modelos navegacionais que exploram interfaces ou movimentos; exploração da construção de mundos virtuais; e modelos de conexão que permitem ao usuário participar remotamente do trabalho". (PAUL, 2015, pág. 71).

Foi essa revolução digital e a entrada do computador que desmantelou cada vez mais as fronteiras entre cinema, vídeo e televisão. O computador se tornou, portanto, o principal vetor de transformação da linguagem do vídeo, o responsável pelo movimento de enevoamento das fronteiras dessa mídia, pelo fato de que praticamente todas as máquinas de produção de imagens em movimento, como computador, câmera fotográfica, o projetor digital, são fruídos por meio de telas com sinal de vídeo como já apresentado por Sean Cubitt anteriormente. Paul levanta, portanto, a questão que aqui mais nos interessa nessa relação com o digital, como essa configuração permitiu o surgimento de espacializações diferenciadas nos ambientes instalativo. Sobre essa questão, a autora declara:

\footnotetext{
O meio digital tem afetado e reconfigurado as imagens em movimento de várias formas e em diversas áreas. As tecnologias digitais oferecem múltiplas possibilidades para um aumento das representações cinemáticas em instalações, uma continuação das espacializações da imagem em um ambiente físico. (...) A interatividade é outro aspecto do meio digital que proporcionou um profundo impacto nas narrativas e nãonarrativas fílmicas, e é inextricavelmente conectada com o conceito de databases, a possibilidade de montagem e reconfiguração de elementos a partir da compilação de uma sequência de imagens. (PAUL, 2015, p. 96-97)
}

Lev Manovich (2001), apresenta também cinco características principais que abarcam o digital e seu aparecimento na cultura, princípios esses que provavelmente devem ter gerado aqueles propostos por Christine Paul. O primeiro deles trata-se da representação numérica, ou 
seja, os objetos do advento do digital podem essencialmente ser representados por meio de funções matemáticas, sujeito a manipulações algorítmicas. Em segundo lugar (não em ordem hierárquica) a modularidade, ou o que autor também chama da estrutura fractal das novas mídias. Nesse princípio Manovich aponta que os objetos, sejam eles imagens, sons, formas, são apresentados por meio de estruturas discretas (o pixel, por exemplo) que podem ser moldados em diferentes escalas sem perder suas características identitárias separadas, ou seja, não se mesclam para a mudança de estado. Por serem armazenadas de modo independente, cada uma dessas estruturas discretas se molda também de forma independente para o trabalho de manutenção de suas características.

O terceiro princípio é diretamente baseados nos dois anteriores. Por ser formado por representações numéricas e armazenados independentemente, os dados do digital permitem uma automação nas operações com esses elementos, uma criação de conteúdos que até certo ponto pode ser independente da ação humana, que interage muito mais com a interface que permite a real modificação de um conteúdo. O autor traz como exemplo a utilização de softwares como Adobe Photoshop, em que a modificação de cor, tonalidade, construção de formas podem ser geradas automaticamente a partir da simples escolha de uma ferramenta com um código específico para essas transformações. O quarto princípio, o da variabilidade, consiste na possibilidade de modificação ao infinito desses objetos criados e armazenados no computador. Por último, o autor elenca a transcodificação, processo que implica uma transformação de materiais de outras mídias em formato digital. Esse processo, no entanto, não se refere simplesmente à conversão técnica de uma fita magnética em dados numéricos por exemplo, mas à discussão de um campo cultural mais amplo que objetos se reformulam na lógica do digital para conferir uma existência que possa ser mais disseminada.

Esses princípios apresentados por Manovich rememoram também uma das questões que Christine Mello (2008) apresenta em seus estudos, as práticas de compartilhamento do vídeo. Para Mello esse processo de compartilhamento se dá pelo contato com outra linguagem, no caso o digital, com elementos como a webcam, na distribuição do vídeo na internet por meio de websites como vimeo, youtube, na estética do videogame, em CD-ROMS e DVD-ROMS, algo como aquela sobrevivência contemporânea que Machado (2007) destaca, o compartilhamento da lógica do digital pelo vídeo e que amplia essas discussões para um espaço virtual da web.

Propostas como o Projeto Telepatia (2003) são exemplos desse compartilhamento de vídeos na web, além de levantar questões acerca de uma visualidade diferenciada de fruição que se dá tanto de modo linear quanto na simultaneidade. Nesse projeto uma série de artistas (entre eles Daniel Seda, José Luis Sampaio, Erik Thurm, Paulito, Rogério Borovik, Filípe 
Spíndola e Bruna Guedes entre outros) se propõem à realização de um projeto Lítero-áudiovisual, segundo nomenclatura dos autores, que lentamente desembocará na criação de um longa-metragem de característica fragmentada, experimental e não-linear. O argumento parte da reunião de um grupo de ativistas libertários de todo o planeta que desenvolveram capacidades telepáticas e passam a se comunicar entre si sem a necessidade do advento de qualquer máquina para que isso acontecesse, e começam então a realizar "atos orquestrados de terrorismo poético com o objetivo de desestabilizar a ordem hipnótica da nossa sociedade de zumbis" $^{25}$. No blog do projeto vemos uma interface que conta com informações textuais referentes ao argumento, participantes e créditos, e uma série de doze pequenos vídeos (com durações que variam entre os trinta segundos e os três minutos).

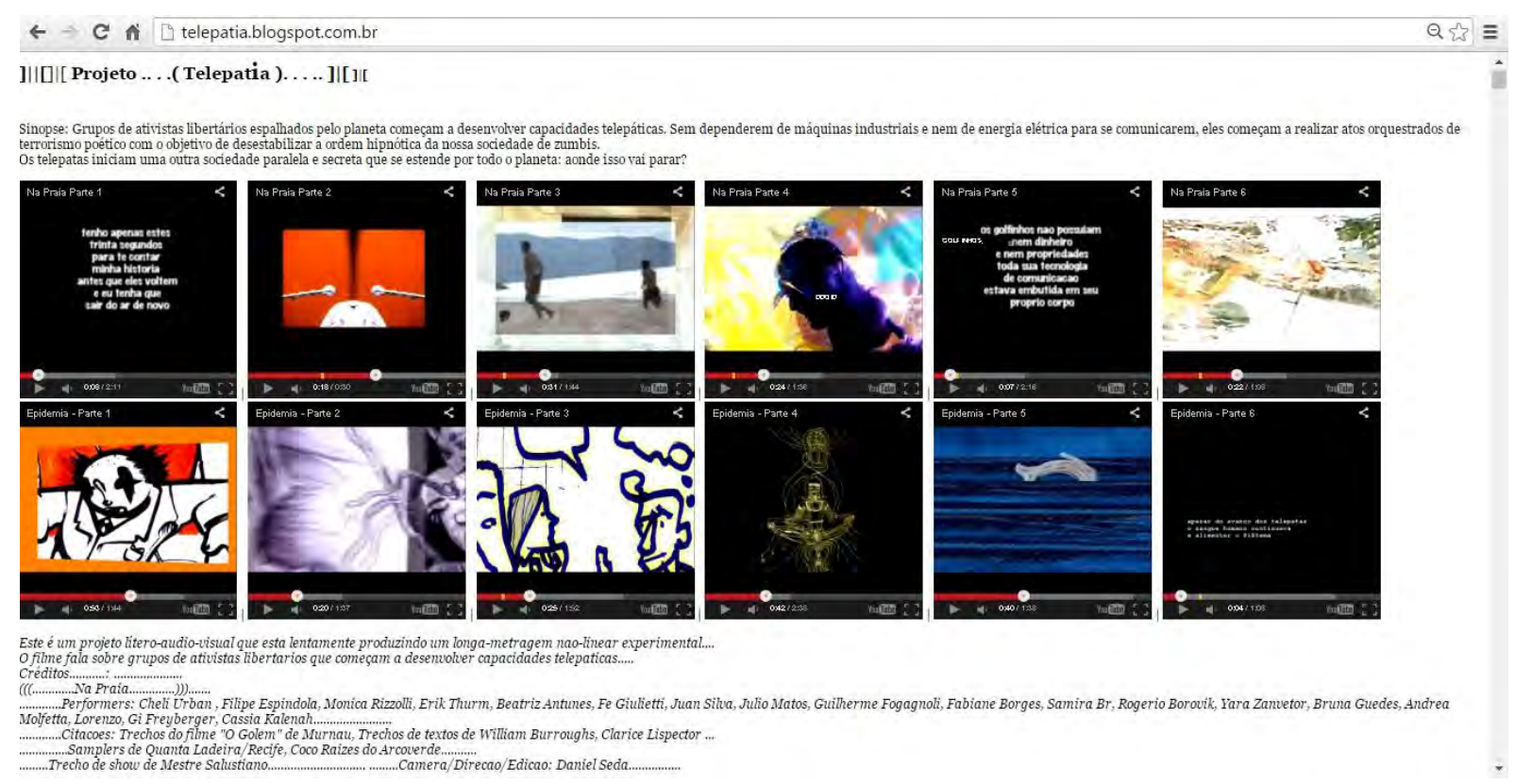

Ilustração 13: Interface do blog do "Projeto Telepatia" Fonte: www.telepatia.blogspot.com

Os vídeos dividem-se em duas séries diferentes, Na praia, com um total de seis vídeos, e Epidemia, com mais seis vídeos, todos sempre iniciados ou interrompidos por pequenos textos que de certa maneira desencadeiam a narrativa do projeto e ligam os vídeos entre si. Os seis primeiros vídeos são fragmentados, formados por imagens que se sobrepõem em transparências, janelas, duplicações e apresentam diversos locais e pessoas em um caos acelerado do que parecem ser as referências de vivência de cada um desses personagens 
telepatas, como num encontro imagético entre essas mentes para a construção desse plano de terrorismo poético. As frases do início do primeiro vídeo já revelam essa perspectiva de comunicação, onde lemos "tenho apenas estes trinta segundos para te contar minha história antes que eles voltem e eu tenha que sair do ar de novo", e refletem ainda sobre esse processo de comunicação telepática, como na frase "em um mundo onde a TROCA se tornou também uma tirania e uma obrigação a maior subversão seria permanecer em um estado de meditação constante a fim de não pensar”.

Os seis vídeos seguintes, a Epidemia, evidenciam por meio de imagens e frases aspectos da metodologia que deveria ser utilizada para o alcance desse estado de diálogo por meio da reflexão silenciosa, uma ação de "terrosismo telepático" conforme anuncia um dos vídeos. Para que essa situação se instaure os artistas propõem a criação de jogos telepáticos para o treinamento do poder por meio da invasão da privacidade mental, destruindo os laços de propriedade e ódio a partir do apagamento da memória e auto-conhecimento do corpo sem o atravessamento por altas tecnologias. Esses vídeos, ao contrário dos seis primeiros, possuem um ritmo muito mais lento e são formados por animações que parecem remeter em seus temas e movimentos a um processo de quase hipnose a partir das imagens. Essas imagens e sons evidenciam elementos como metáforas sonoras dos biosonares dos golfinhos, os balões de pensamentos das histórias em quadrinhos vazios, desenhos que simulam ligações mentais entre pessoas a partir de elementos corporais, ou desenhos de ataques de zumbis.

Esse sentido de costura entre os vídeos deriva, no entanto, de uma leitura linear da interface do blog em que os vídeos se encontram armazenados. Em uma disposição que nos remete a uma espécie de videowall na web, esses vídeos podem, no entanto, ser vistos em ordens aleatórias diversas, mais de um ao mesmo tempo, ou mesmo todos simultaneamente. Essa experiência de simultaneidade ou de desarranjo da ordem levaria a narrativa para infinitas possibilidades de leitura. Se pensarmos nessa página da web como quadro, vemos ali mecanismos de espacialização a partir de uma diversidade de doze pequenos quadros de vídeos que se interconectam e podem ser ativados aleatoriamente, gerando um espaço múltiplo, uma característica tão cara às produções de videoarte. Esse tipo de espaço reside, portanto, na unidade de cada vídeo armazenado e no conjunto da relação entre os vídeos.

Essas mesmas relações são potencializadas em websites, onde uma gama de possibilidades de hiperlinks levam quem ali navega a uma experiência de espacialização diversa. Foquemos, no entanto, em como o vídeo aparece nessas situações. Muito parecido com os websites, alguns trabalhos em CD-ROM e DVD-ROM problematizam essas questões de páginas e layers que se interconectam e trocam, levando uma em direção a outra, é o caso da 
obra Bodyweave ${ }^{26}$ (2005) de Lali Krotoszynski ${ }^{27}$, desenvolvido e parceria com o Núcleo Interdisciplinar de Comunicação Sonora (NICS) da Universidade Estadual de Campinas e outros nomes como Jônatas Manzolli (orientação geral) e Jarbas de Moraes Neto (Programação). Na tela inicial desse CD-ROM visualizamos um fundo branco onde no centro se localizam trinta e seis pequenos círculos de cores diversas. Cada um desses círculos emite um pequeno ruído sonoro de aproximadamente três segundos a cada vez que são selecionados pelo cursor do mouse. Essa primeira tela orienta o público a selecionar, a partir dos sons emitidos, três desses círculos, o que nos leva a uma segunda tela do trabalho.

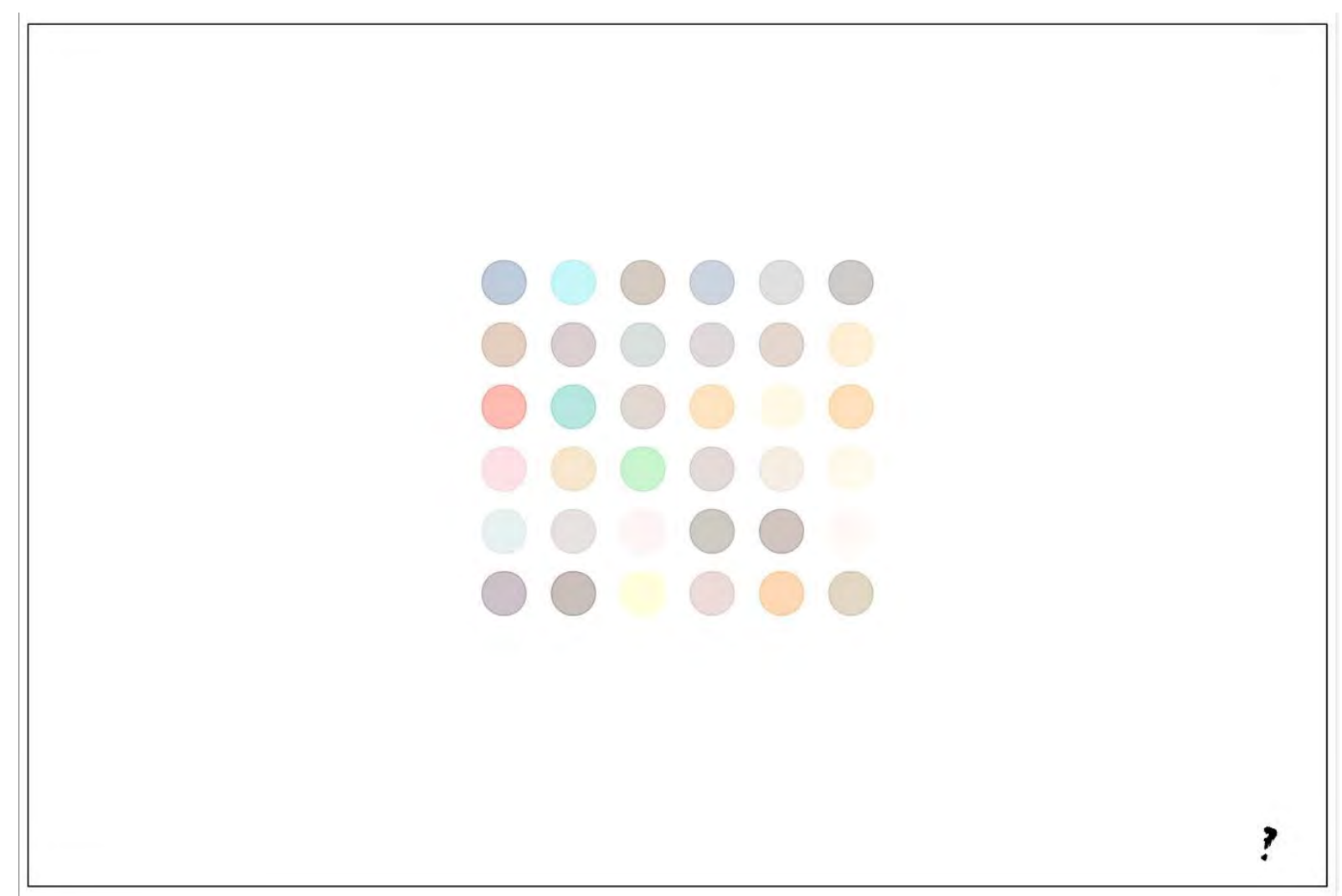

Ilustração 14: Captura da tela de introdução da versão em CD-ROM da obra Bodyweave (2005) de Lali Krotoszynski

Fonte: Acervo da Associação Cutural Videobrasil

Nesta segunda etapa vemos inicialmente seis retângulos brancos posicionados em sentido horizontal um ao lado do outro. No fundo branco maior da tela vários daqueles círculos

26 Este trabalho foi reformulado ao longo dos anos e existe também em versão online disponível no endereço www.bodyweave.net.

27 "Doutoranda em Artes Visuais e Mestra em Meios e Processos Audiovisuais pela Universidade de São Paulo. Sua carreira se caracteriza pela investigação das possibilidades de integração da dança e outras linguagens da arte aplicadas na criação e na atividade didática". Fonte: ww.videobrasil.org.br 
da tela anterior aparecem agora em tamanhos diversos, e em ordem aleatória. O espectador é solicitado a partir do botão Help a escolher seis dos círculos da tela, e cada um desses círculos deve ser selecionado e arrastado até cada um dos retângulos citados anteriormente. Ao arrastarmos e soltarmos esses círculos até os retângulos surge uma imagem que o preenche, e que pode ser diferente ou repetida.

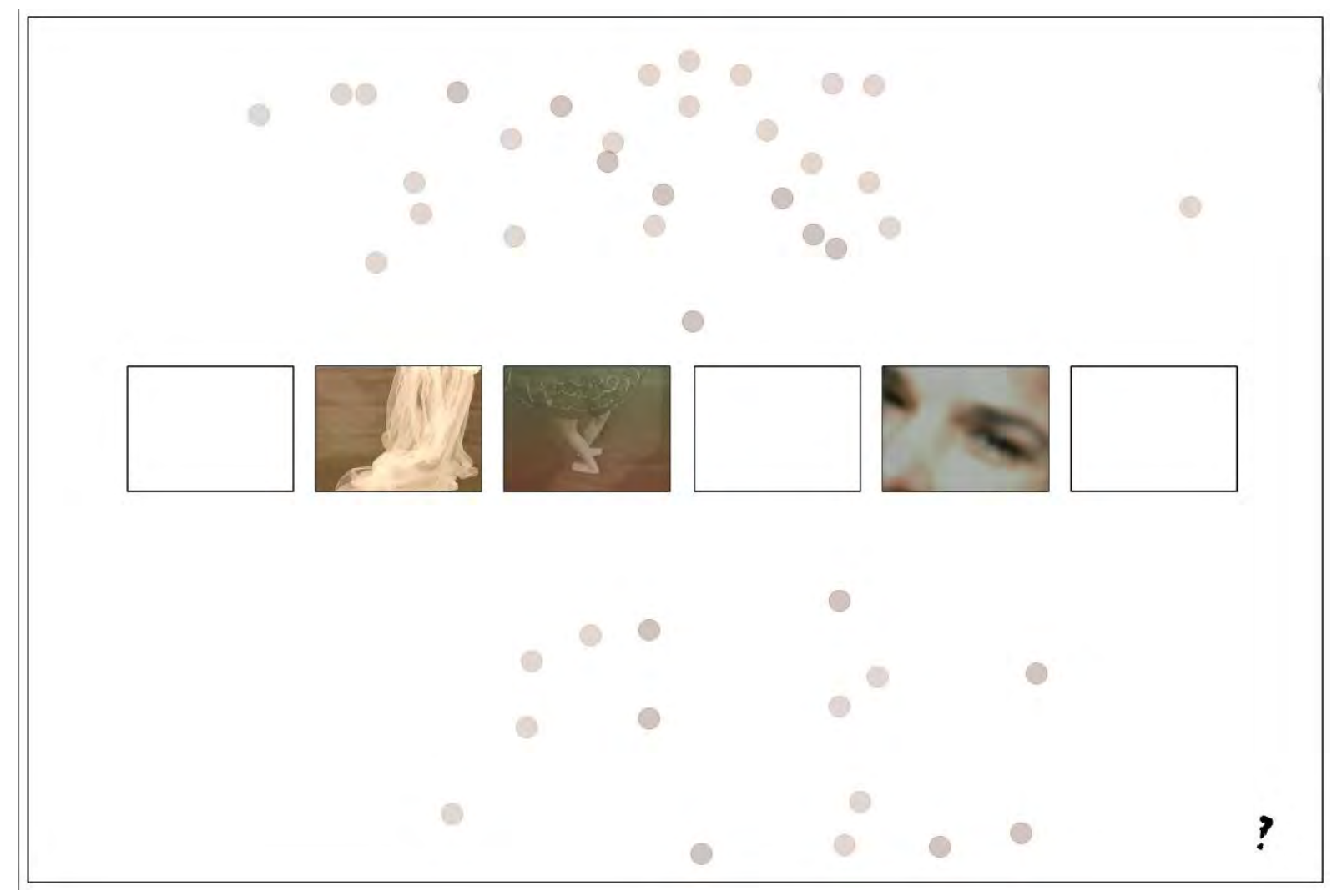

Ilustração 15: Captura da segunda tela para interação da versão em CD-ROM da obra Bodyweave (2005) de Lali Krotoszynski

Fonte: Acervo da Associação Cutural Videobrasil

Ao término do preenchimento dos seis retângulos com as imagens correspondentes a cada um dos círculos selecionados vemos o surgimento automático de uma terceira tela em substituição à segunda. Nesta o que visualizamos é a formação também automática de um pequeno vídeo a partir da sequência das seis imagens selecionadas anteriormente, combinando também os sons correspondentes. As imagens configuram-se de uma série de corpos que aparentam dançar em alguma cena e aparecem em sua totalidade ou fragmentados, como pernas, rostos, olhos. O vídeo apresentado surge a partir de movimentos acelerados de alternância das imagens escolhidas, gerando um produto que se assemelha àquele ritmo apresentado nos landscape films e nos vídeos citados de Lucas Bambozzi e Dirceu Maués. 


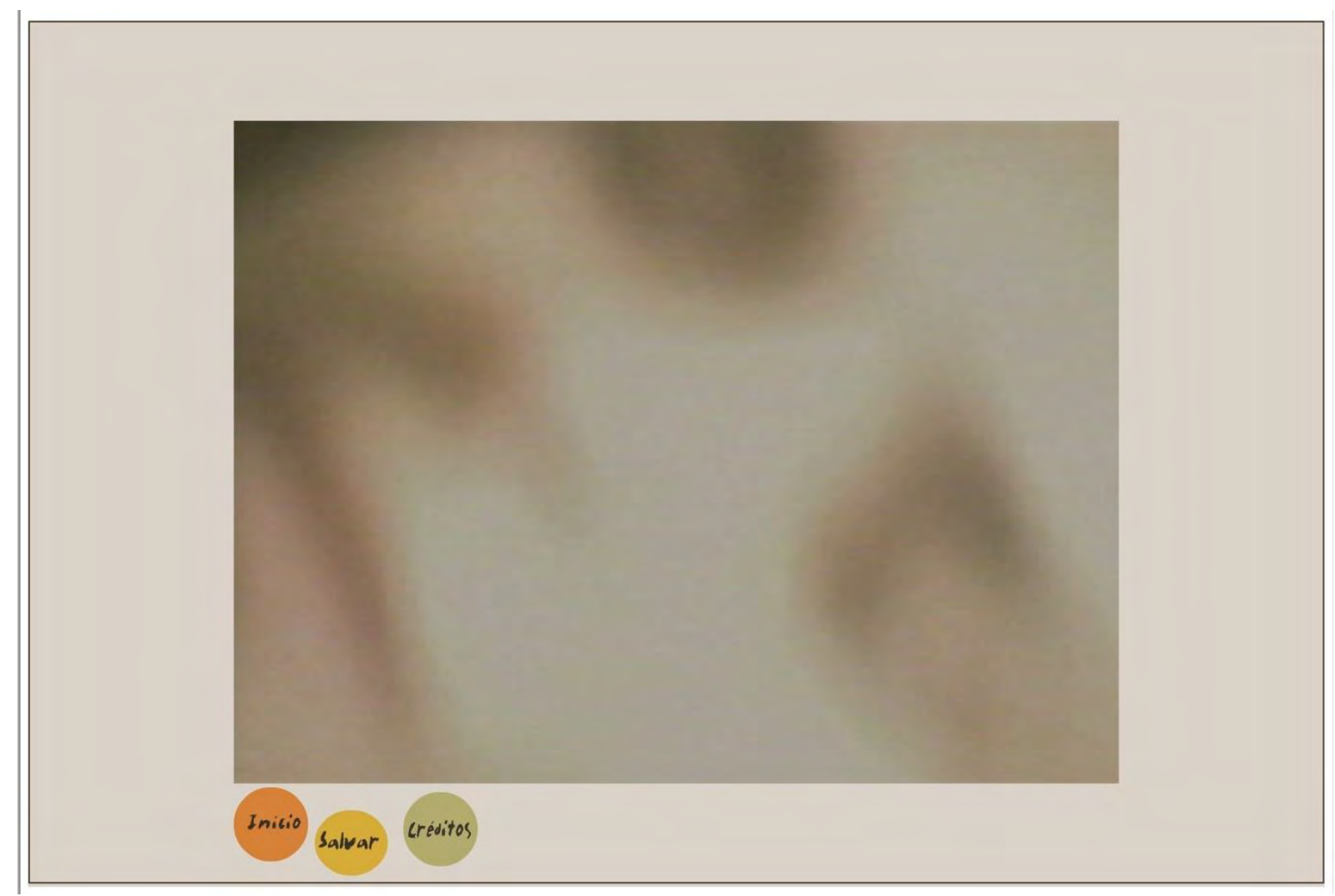

Ilustração 16: Captura de tela do vídeo gerado pela interação com a versão em CD-ROM da obra Bodyweave (2005) de Lali Krotoszynski

Fonte: Acervo da Associação Cutural Videobrasil

O trabalho de Lali Krotoszynski materializa ainda aqueles princípios do digital que Lev Manovich e Christiane Paul identificam. A participação e interação na necessidade de escolha e ação sobre determinados elementos na tela, a automação na geração das formas a partir do contato com interfaces (no caso os círculos e sons) e, muito importante, a variabilidade na produção do conteúdo, na medida em que o vídeo final exibido pode existir em infinitas possibilidades de combinação de imagens que dependerão dos círculos e seus sons escolhidos pelo participante anteriormente. Dificilmente veremos o mesmo vídeo ao final da experiência imediata com a obra, já que as interfaces que possibilitam a construção dele se organizam a todo o tempo também de maneira diferente e variável. De modo geral, aquele princípio da transcodificação, levantado por Manovich, aparece na reformulação das práticas para a geração do vídeo ao final do trabalho a partir da lógica do digital e seus princípios norteadores.

O surgimento da produção digital traz outro importante fator, o aparecimento da projeção digital em alta definição, o que possibilitou que os artistas deixassem de lado a relação com a imagem espacial da televisão e do monitor, para se dedicar às experiências mais cinemáticas e para além disso, o que Tamara Trodd (2011) problematiza com relação à 
visibilidade do aparato televisivo nos primeiros anos da videoarte e a invisibilidade do aparato da imagem em movimento após o advento da projeção digital. O digital também permitiu que o vídeo passasse a ser projetado em superfícies diversas, além do monitor e do retângulo da projeção. O principal exemplo é o surgimento do videomapping, que permitiu que o vídeo se adequasse espacialmente uma série de superfícies, de certa maneira retomando algumas características da vídeoescultura.

A relação com as tecnologias digitais do computador também possibilitou o surgimento de propostas interativas em que o espectador tem a possibilidade de realizar efetivas modificações no espaço em que está inserido bem como, em alguns casos, na própria narrativa videográfica, além da relação com a World Wide Web e o aparecimento do videostreamming, por exemplo. Com o digital as características, definições e diferenças entre mídias foram sendo borradas, em função do formato de exibição e da alta qualidade do vídeo. Essas características devem então desembocar numa discussão acerca do nosso papel frente as modificações causadas pelo advento do digital. Timothy Barker (2012) propõe esse mesmo pensamento, de como a nossa experiência de tempo e espaço está diretamente relacionada com a nossa relação com as tecnologias que nos rodeiam e que o avanço das tecnologias de comunicação nos proporcionou uma reestruturação das noções de localização (pensemos no skype), levando a atuação humana no mundo para uma direção em que o deslocamento geográfico já não é mais necessário para certas situações.

O tempo do digital, para o autor passa por uma temporalidade da interatividade que os códigos e ferramentas do computador, por exemplo, permitem. Isso desembocará na discussão que será realizada a frente no que se refere ao processo de interatividade de trabalhos instalativos, com o vídeo como sua grande força na construção de um espaço de exibição nas galerias.

\subsection{VIDEOARTE NA GALERIA}

Para Phillippe Dubois o termo videoinstalação, uma das vertentes de instauração do vídeo nas galerias, parece agregar as questões arquitetônico-espaciais que a nomenclatura instalação busca. Michael Rush (2006) levanta questões importantes acerca desse novo dispositivo, que abarca o público participante de uma outra maneira, assumindo o papel de "energizar" o espectador para a tomada de atitudes frente aos objetos, ao dispositivo vídeo. Enquanto nos processos de vídeo mono-canal o processo de espacialização acabava por se 
realizar em alguns casos exclusivamente pelo artista na edição, nessa nova configuração o público toma partido como agenciador de certas atitudes como veremos adiante, em que o vídeo se torna uma experiência escultural e espacial. Anne-Marie Duguet (2009) levanta questões referentes ao espaço e circulação como elemento fundador e propomos pensar, portanto, a arquitetura dos museus e galerias como elemento essencial para a produção de vídeo. A autora declara:

(...) a arquitetura desempenha papel essencial na concepção dessas obras. Ela não constitui uma simples modalidade original de "apresentação" da imagem, nem um ornamento ou um avatar da decoração teatral ilusionista. Em vez dessas opções, ela é organização do próprio visível e estrutura suas condições de percepção. (...) As instalações de vídeo por sua vez, ativaram a mobilidade do ponto de vista, que passou a ser produto não apenas da imagem, como também do espectador, necessariamente engajado num percurso (DUGUET, 2009, p.65-68).

A vontade dos artistas do vídeo de expandir suas práticas de espacialização para além do quadro da tela fica clara no uso inicial de instalações com vários monitores até o surgimento das grandes projeções a partir do advento do vídeo digital, quando a imagem do vídeo pode ser exibida em grandes proporções em função da sua melhora de definição. Complementando, segundo Dubois (2004), para que o vídeo se integre ao sistema audiovisual enquanto forma de pensar as imagens (Estado-vídeo) é necessário analisá-lo enquanto dispositivo, ou seja, as reformulações espaciais, seja em um monitor de TV, nessas expansões esculturais ou num grande espaço instalativo. O autor nos parece propor pensar o vídeo justamente como espacialização, já que as imagens do vídeo não apresentam necessariamente objetos análogos contemplados num fora da tela, mas traz um jogo de relações entre elementos espaciais e temporais que só existe ali, de modo a pensar esse tipo de imagem, contaminada por incrustações, sobreimpressões e jogos de janela como espécies de instalações, por seu cerne fundador ser justamente os deslocamentos espaciais.

O caminho contrário também acontece, segundo Dubois, ao pensarmos a instalações em sua forma completa, e não apenas o conteúdo audiovisual, como imagem. Vemos aqui como esses mecanismos de decomposição espacial refletem no surgimento das instalações com vídeo como questionadoras do lugar de instauração da imagem. Esse processo a partir daqui requer o espaço externo ao monitor pra a completude de um sentido poético. Não basta mais trabalhar com as camadas internas, os artistas querem dialogar com um espaço tátil dos museus e galerias, que pode ser percorrido como elemento integrante do vídeo enquanto dispositivo. A questão da interatividade tem se mostrado como uma tendência produtiva nesses trabalhos, principalmente no que se refere àqueles que utilizam a linguagem digital, como discutido anteriormente, como 
vetor essencial para a experiência com a obra. Aqui se compreendem principalmente as manifestações intermediadas por linguagens de programação.

Partirmos aqui de uma ideia fundamental para a construção da análise que se segue, a de que quando o vídeo se espacializa ele pressupõe um discurso de interação. A vontade de propor espaços de interação parecer ser um dos motivos pelo qual artistas buscaram esse processo de expansão do vídeo para o ambiente físico. Os níveis de interatividade trazem em seu cerne uma vontade do artista de criar um diálogo mais, ou menos, interativo com a obra, de delegar mais, ou menos, papéis a esse público enquanto construtor e agente de transformação da poética apresentada. Obviamente podemos falar de uma interação em qualquer tipo de obra, já que o público se presta a ver, ler e interpretar em qualquer circunstância e em obras de qualquer natureza. No entanto, nesse novo momento o público passa a ser convocado para estabelecer relações táteis com os objetos, a percorrer o espaço multiplamente unificado dessas exposições com obras onde pensar o vídeo não se limita à tela que transmite o conteúdo audiovisual, mas a todo o dispositivo que se apresenta no espaço junto a tela. Estamos aqui no âmbito de entendimento de dispositivo que Phillipe Dubois (2004) contempla, esse estado do vídeo como espaço de interligação entre elementos. Sobre o dispositivo, Jacques Aumont (1993) afirma que:

\footnotetext{
As determinações fisiológicas e psicológicas (...) da relação do espectador com a imagem não bastam para descrever completamente essa relação. Aliás, esta se dá em um conjunto de determinações que englobam e influenciam qualquer relação individual com as imagens. Entre essas determinações sociais figuram em especial os meios e técnicas de produção das imagens, seu modo de circulação e eventualmente reprodução, os lugares onde elas estão acessíveis e os suportes que servem pra difundilas. É o conjunto desses dados, materiais e organizacionais, que chamamos de dispositivo. (AUMONT, 1993, p. 139).
}

A questão principal que gostaríamos de levantar neste tópico é o fato de que a galeria teria se tornado um espaço propício para a existência desse dispositivo do vídeo por justamente possibilitar ao espectador um engajamento que não ocorre na televisão nem na sala de cinema. E esse engajamento é passeante, faz parte de um tempo de fruição que é próprio do espectador, o que lhe dá autonomia no espaço e na sua relação com a mídia, fugindo do bombardeamento da televisão e da anulação/prostração dos corpos nas salas convencionais de cinema. O que diferencia a instalação é justamente o fato de que o espectador não está meramente engajado no espaço virtual bidimensional da tela, mas sim no espaço físico da galeria.

Por outro lado, essa questão é também polêmica. Ao realizar uma comparação entre 
esses papéis conferidos ao espectador na galeria e na sala de cinema, Erika Balsom fala de um "mito da atividade". Antes de analisarmos essa questão, vejamos como a autora descreve esses dois espaços citados:

\begin{abstract}
A sala de cinema é um espaço de cultura de massa para um entretenimento violento e erotismo clandestino. A realidade anônima, a escuridão, o gigantismo da tela, os ritmos imperceptíveis do flicker emanando do projetor -todos esses elementos servem para dar suporte ao poder do filme por si só, consolidando a atenção e fascinação do espectador. Os protocolos do espaço da galeria são diferentes. O nível de luz é mais alto e o visitante vagueia a vontade, talvez até mesmo falando com alguma companhia. A atividade é dotada de um senso de respeitabilidade cultural, até mesmo erudição, e tende a suprimir a capacidade absortiva do cinema. A forma arquitetural do cubo branco, popularizado na década de 1920, é inextricavelmente relacionada à ideologia do modernismo e ao desejo de uma autonomia da arte, livre dos tentáculos contaminadores da cultura de massa vista como governada primeiramente pelos imperativos do mercado. (BALSOM, 2013, p. 39, tradução nossa).
\end{abstract}

Ao dar continuidade à sua análise, Balsom explicita ainda que a galeria não pode ser vista como como um espaço em que obras de arte estão contidas, mas como uma meta-mídia a ser investigada, um lugar que dota esses objetos de um valor cultural. O visitante que ocupa esse lugar seria também dotado de uma liberdade passeante, de um tempo de fruição muito mais dilatado e que se funda em uma auto-responsabilidade de agenciamento dos percursos no espaço, em oposição a um certo ar de disciplinaridade do corpo na sala de cinema. O mito dessa atividade reside, para Balsom, no fato de que o que acontece na realidade é a mudança de um exercício de poder de centralização do espectador, para uma outra forma de poder no espaço da galeria que preza por essa flexibilidade e liberdade.

Essas características de circulação, temporalidade e fruição diferenciadas já não são mais, para a autora, atividades de resistência, mas a própria nova regra de atuação nesses espaços, que assim como na sala de cinema podem levar também a uma experiência de paralisação intelectual, reduzindo esse movimento do corpo no espaço das galerias a uma semelhança com o passear por vitrines de lojas comerciais, dado os aspectos de espetacularidade que muitas exposições, especialmente aquelas de imagens em movimento, proporcionam. Balsom preza, portanto, por uma não oposição dessas experiências da sala de cinema e da galeria, mas esforça-se em compreender o lugar das experiências proporcionadas por cada uma de maneira não hierárquica. A discussão da autora exemplifica bem como em um âmbito macro da constituição desses dois dispositivos, a galeria e a sala de cinema, o discurso circulante pode ser o próprio fundador e mesmo paralisador das experiências. Para Foucalt (2006) o discurso: 
(...) nada mais é do que a reverberação de uma verdade nascendo diante de seus próprios olhos; e, quando tudo pode, enfim, tomar a forma do discurso, quando tudo pode ser dito e o discurso pode ser dito a propósito de tudo, isso se dá porque todas as coisas, tendo manifestado e intercambiado seu sentido, podem voltar à interioridade silenciosa da consciência de si (...) o discurso nada mais é do que um jogo, de escritura (...) de troca (...) e essa troca, essa leitura e essa escritura jamais põem em jogo senão os signos. (FOUCALT, 2006, p. 49).

Como problematiza Foucault na citação acima, o discurso se incorpora socialmente por escritas, leituras e trocas, e o autor de um trabalho de arte pode ser, portanto, um arranjador em potencial de elementos que compõem esse discurso, alguém que organiza e interconecta signos para a formulação de uma situação de comunicação, um acontecimento discursivo operado por meio de dispersão, acumulação e seleção. O discurso como materialização de ideologias. Nesse sentido, as escolhas técnicas de um artista influenciam diretamente a relação que ele almeja que público tenha ao experienciar seu trabalho. Para nós essa escolha reflete o potencial interativo do trabalho em relação ao público. Um vídeo exibido em um monitor de pequenas dimensões, por exemplo, pressupõe muito menos interações táteis do que trabalhos em que o vídeo está projetado no espaço e estabelece relação com informações computacionais em que o público pode mexer e escolher as imagens que lhe convém. Essa discussão de interação que impera entre as produções contemporâneas parece configurar-se como o que Gregolin (2006), ao recuperar Foucault, traz à tona como uma formação discursiva, em função das ordens, recorrências e funcionamentos que se entrelaçam para construir um tipo de produção que tem objetivos interativos em comum.

Ainda segundo Foucault esse discurso só poderá existir por meio de uma materialização qualquer, o que a grande maioria dos estudiosos das imagens técnicas chamam interface28. Para nosso estudo interessa compreender que o processo de espacialização do vídeo na arte contemporânea, a saída do aparelho de televisão ou computador para experiências de projeção configurou um discurso que se perpetuou ao longo da história da arte e traz em seu cerne a problemática da interação. Neste momento fomentamos a ideia de que possivelmente o nível de interação de um trabalho é definido por meio das escolhas técnicas dos artistas que permitem uma certa espacialização.

Como discurso esses espaços são também indefinidamente lugares de certo controle, como já pontuado por Balsom, e essa é mais uma problematização colocada no âmbito desses novos meios pelos quais a arte contemporânea tem cada vez mais se dedicado. Já se tornou um discurso de tendência o fato desse tipo de produção mostrar-se como "obra aberta", apta a

28 Dispositivo físico ou lógico que faz a conexão entre dois equipamentos que possuem diferentes funções e que não poderiam se conectar diretamente. (MACHADO, 1988, p. 213). 
integrar o espectador de maneira mais livre e imersiva. No entanto, a prática analítica dessas propostas nos leva a levantar algumas questões que envolvem essa concepção circulante de interatividade. Muitos dos trabalhos que se dizem interativos são na verdade meramente reativos.

Cláudia Giannetti (2006) citando Chistoph von der Malsburg declara que para que haja de fato uma interatividade no âmbito do computacional, que atravessa o vídeo em várias propostas por exemplo, é preciso que se apresente um diálogo entre público e interface, o que consistiria em uma troca e autonomia de ambas as partes no processo de significação de um trabalho de arte, ou seja, reações meramente táteis como apertar um botão, mover um mouse, virar uma página seriam na verdade sistemas reativos, em que o espectador apenas modifica possibilidades dadas e limitadas ao programa. Gianetti traz uma discussão referente ao diálogo versus discurso, sendo este último baseado em um processo de controle de uma das partes, o que anularia um diálogo efetivo. Embora esse controle possa não ser facilmente compreendido ou visualizado pelo público, a maioria desses trabalhos de artemídia $^{29}$, baseia-se na construção de interfaces em que as regras do aparelho não são compreendidas pelo público e esse acaba se tornando mero instrumento controlado pelos algoritmos possíveis da máquina concebida pelo artista.

Segundo Christoph von der Malsburg (MALSBURG apud. GIANETTI, 2006, p. 124), é isso que na maioria das vezes acontece na interação homem-máquina por meio do discurso. O artista parece conceber estruturas de manipulação das ações possíveis do público na experiência com a obra e “(...) enquanto o controle for o eixo principal, o computador não poderá assumir a posição de interlocutor numa comunicação com seres humanos" (GIANETTI, 2006, P. 124). Não queremos com isso dizer que o artista constrói sempre conscientemente discursos de poder para ter o total controle das ações do público nas suas mãos, mas que suas escolhas técnicas pressupõem esse controle em certas situações, mesmo que inconscientemente. Esta é a problemática que nos parece assolar a produção e crítica das artes acerca dessas tecnologias que viemos falando, como tornar real essa interatividade que é almejada por esse contexto enquanto formação discursiva que se entremeia na cultura contemporânea das máquinas.

A interatividade nesse caso, deve se instaurar justamente no diálogo entre homem e máquina, uma completude que se dá por esse elemento essencial, a subjetividade. É a partir

\footnotetext{
${ }^{29}$ Termo utilizado por Arlindo Machado, refere-se a “(...) formas de expressão artística que se apropriam de recursos tecnológicos das mídias e da indústria do entretenimento em geral, ou intervém em seus canais de difusão, para propor alternativas qualitativas. (MACHADO, 2007, p. 07).
} 
desse caractere que o público toma forma como agente real de modificação de espaços e imagens. Falamos aqui de uma espacialização mesmo interna, e como esse espaço de experiência interna mostra-se essencial para a existência de uma tactilidade ou de um sistema háptico que será em potencial o transformador de contextos, do artístico ao social, ou do cruzamento entre estes em caráter híbrido. Para Mark Hansen (2006) essa tactilidade é quem abre a possibilidade de um sistema háptico enquanto alternativa a um sistema óptico. A diferença se encontra em como esse tocar configura uma interferência qualitativa no conteúdo artístico ou apenas um regime de imersão inconscientemente controlado pela máquina. Ainda segundo o autor, é a afetividade, um processo corporal e espacial interno quem vai definir, portanto, a maneira como a experiência será externalizada por meio da tactilidade e como isso afetará o caráter de intervenção no espaço e conteúdo.

Nesse processo fica claro o papel essencial que esse espectador deve assumir no agenciamento dessas experiências espaciais com o vídeo. O participador deve ter consciência de que tem que agir criticamente frente a essas propostas, de modo a não deixar seu fazer diminuir-se a um simples apertar de botão disfarçado de interatividade. A principal discussão aqui presente é a do funcionário30, já levantada por Vilém Flusser (2009) em sua Filosofia da Caixa Preta. Para se tornar agente de modificação, o público deveria tomar conhecimento do funcionamento da caixa preta que se materializa em obra, o que é obviamente muito difícil mediante tamanhos avanços tecnológicos que surgem em uma velocidade assustadora e se integram ao sistema artístico.

Walter Benjamin (2012) fala acerca da diferença entre abastecer e modificar um aparelho produtivo. Para o autor essa modificação acontece por meio da derrubada da inteligência que compõe o aparelho, o que significaria aqui uma transformação técnica e afetiva que reestruturasse o conteúdo e forma, para nos tornarmos arranjadores táteis, e não apenas em nível de subjetividade. No entanto, só conseguiremos essa façanha quando pudermos também nos tornar produtores e conhecermos o processo intrínseco da tecnologia. Walter Benjamin caminha para uma derrubada das diferenças entre intérprete e ouvinte e técnica e conteúdo, para que essas experiências se concretizem com o autor não mais como o fabricante de produtos, mas o disponibilizador dos meios de produção. O aparelho é tanto melhor quanto mais levar os consumidores ao âmbito da produção. A questão da interatividade não é, portanto, meramente tecnológica, mas integrada por tecnologia, agenciamento, afetividade, e responsabilidade participativa. Retomando Benjamin, uma grande questão se impõe ao público contemporâneo

30 "Pessoa que brinca com o aparelho e age em função dele (FLUSSER, 2009, p. 77). 
desses espaços de espacialização do vídeo: estar apto a refletir sobre o seu lugar no processo de produção desses ambientes.

Parece claro sim que a utilização do vídeo nas galerias de arte confere outras possibilidades de experiência com essa mídia, que se diferem da utilização doméstica ou comercial da televisão, do comportamento solicitado nas salas tradicionais de cinema ou do navegar no computador e suas espacialidades em nossa casa, por exemplo. Por isso apontamos a importância de pensar esse espaço da galeria como um dos possíveis meios aptos à análise daquela autonomia que vínhamos falando sobre essa mídia vídeo, assentados na força de deslocamento (corporal e teórico) que essa experiência diferenciada proporciona. No entanto, apesar dos ganhos que a abertura para essas novas atitudes assenta, procuramos discutir como o espectador desses espaços deve também estar apto a uma maior conscientização de seu papel nesses aspectos de interatividade que perpassam essa produção contemporânea na relação do vídeo com o espaço.

Nesse capítulo, portanto, o vídeo foi discutido nos seus aspectos de atravessamento e autonomia na relação com a televisão, o cinema e o computador para desembocar e retornar aos seus aspectos arquiteturais do qual é composto no espaço da galeria. Nosso esforço foi o de levantar algumas características dessa mídia a partir de aspectos poéticos e históricos que se relacionam na tentativa de delimitar do que tratamos quando falamos de vídeo.

Desse modo, neste ponto do trabalho elencamos as discussões que se referem às nossas duas variáveis de estudo, o vídeo e o espaço. No próximo e último capítulo iremos nos ater ao estudo de vários trabalhos que estabelecem essa relação entre vídeo e espaço a partir de alguns eixos de análise que estão diretamente atrelados a certos mecanismos de composição que perpetuarão espacializações diferenciadas que vão da imagem do vídeo mono-canal aos ambientes imersivos que utilizam o vídeo em seu arranjo, das pequenas às grandes proporções do vídeo, tomando como elemento de comparação para pensar essas dimensões da presença do corpo do espectador nesses espaços de museus e galerias. 
CAPÍTULO 03

\section{MODOS DE ESPACIALIZAÇÃO DO VÍDEO}


Nos dois primeiros capítulos deste trabalho preocupamo-nos em apresentar algumas características dos dois elementos que interessam a nossa pesquisa. Por um lado, levantamos discussões referentes à concepção de espaço, em uma perspectiva da problematização do espaço do quadro videográfico e do espaço físico, materializado em nossos estudos por meio desses espaços arquitetônicos fechados que abrigam propostas de arte, como as galerias. No segundo capítulo levantamos questões referentes a uma delimitação do que se trata para nós o vídeo, permeado por algumas características que o atravessam por meio de certas práticas e métodos de trabalho no âmbito da televisão, do cinema e da linguagem computacional, além de problematizarmos a questão da interação nesses espaços arquitetônicos em que o vídeo se instala. Nesse levantamento chegamos a apresentar como essas relações de certa maneira já apresentam algumas problematizações referentes ao processo de espacialização do vídeo dentro do quadro, que estarão presentes em alguns dos trabalhos que analisaremos a partir de agora em formato mono-canal ou instalativo.

Retomamos aqui o principal elemento que unifica as discussões de nosso primeiro capítulo, a espacialização, para pensar como esse processo se desenvolve no âmbito da produção de videoarte exibida nesses lugares já citados. Relembrando suas características, essa espacialização de que falamos seria um processo de composição que discute essencialmente as questões espaciais, ou seja, um dos possíveis trabalhos que a ação maior de composição funda. Nesse sentido, nesse capítulo objetivamos elencar alguns desses modos de espacialização que atravessam a videoarte a partir da apresentação conjunta de alguns trabalhos que exemplificam essas relações. Essas práticas tem atravessado a história da videoarte desde o seu surgimento, como já apontamos no segundo capítulo por exemplo, a partir do advento do corpo conceitual de que Michael Rush (2014) fala nas videoperformances. Para pensar essas práticas, o atravessamento de uma situação é importante para nós, a dimensão física da obra (seu tamanho) e as atitudes suscitadas aos espetadores (direta ou indiretamente) quando em contato com esses trabalhos. As relações estabelecidas nessa situação, e que compõem a própria natureza de dada poética da obra em vídeo levantam, portanto, aquelas questões que discutimos sobre a existência de certos discursos de interação.

De maneira mais direta identificamos a existência de duas dimensões de experiência, a primeira relacionada a um processo de dominância física da imagem do vídeo pelo corpo do espectador e a segunda a uma situação de imersão desse mesmo corpo em ambientes. Queremos pontuar que de maneira alguma objetivamos reduzir a experiência com obras em vídeo a essas duas situações, sabemos da infinidade de fatores que a perpassam, desde de características fisiológicas ao contexto cultural de produção desses trabalhos. Aqui efetuamos um recorte de 
elementos que de maneira geral correspondem aos questionamentos específicos de nossa pesquisa. Procuramos apenas apontar algumas recorrências na relação com a espacialidade que temos observado em nosso contato com essa produção contemporânea, que podem ser expandidos em diversos campos de análise e abordagens em pesquisas futuras.

Essas duas dimensões citadas são pensadas então a partir de um elemento, o tamanho da imagem. Jacques Aumont (1993) afirma ser essa uma das principais questões a se considerar quando falamos de um dispositivo qualquer, em nosso caso, o vídeo. Lembramos que, quando falamos do dispositivo vídeo aqui, nos referimos a totalidade de elementos que o compõem em seus formatos mono-canal e instalativo, inclusive a presença do espectador no espaço e não apenas à imagem bidimensional que aparece no monitor ou na projeção. Para o autor o tamanho que a imagem é apresentada é um elemento que determinará que tipo de relação o espectador estabelecerá entre seu próprio espaço (as dimensões de seu corpo) e o espaço do dispositivo, exemplificando a partir da força que imagens de grandes dimensões, em que nem o recuo do corpo no espaço permite a visualização total, fundam uma relação de imersão em que a imagem toma o espectador num sentido quase esmagador de imersão, contrário à relação de posse, quase fetichização que as imagens fotográficas em pequenas dimensões, nos álbuns de família, por exemplo, estabelecem. Ainda sobre essas questões relacionadas ao tamanho do objeto, o artista Robert Morris, a respeito da escultura, declara que:

\begin{abstract}
A consciência da escala é uma função da comparação feita entre aquela constante, o tamanho do corpo, e o objeto. $\mathrm{O}$ espaço entre sujeito e objeto está implícito nessa comparação. Nesse sentido o espaço não existe em objetos intimistas. Os grandes objetos incluem mais do que os pequenos objetos o espaço ao seu redor. É necessário literalmente manter uma distância dos grandes objetos para apreender o todo em um único campo de visão (MORRIS, 1966, P. 231).
\end{abstract}

A fala de Morris parece, portanto, corroborar com a perspectiva de Aumont ao tomar o corpo como elemento de referência para o estabelecimento de escalas. No entanto, acreditamos que os pequenos objetos compreendem sim uma questão de espacialidade, ao contrário do proposto pelo artista, que no período de escrita deste texto estava muito preocupado em delimitar uma força no campo da arte para aquelas grandes estruturas que vinham surgindo na década de 1960, como o movimento minimalista que citamos em nosso primeiro capítulo. A relação espacial que se estabelece entre objetos de pequenas dimensões e objetos de grandes dimensões não são, portanto necessariamente opostas ou se preocupam menos com discussões espaciais, são apenas de naturezas distintas na relação com esse corpo. O fato de um grande objeto solicitar um distanciamento corporal do espectador, um movimento de abandono, não 
significa que ele é mais complexo ou valoroso do que um objeto de pequenas dimensões. De qualquer modo, todos os objetos em grandes dimensões ou mesmo ambientes são apenas fruídos de modo totalizante? Apontamos, portanto, que mesmo essas grandes dimensões abrigam uma intimidade pela proximidade, da leitura pelas camadas estruturais menores que forma esses objetos.

Ao primeiro exemplo citado por Aumont podemos claramente relacionar às práticas contemporâneas de utilização de grandes projeções de vídeo nas galerias. Milton Sogabe (2008) chama a atenção para como isso se desenvolveu ao longo da história na linguagem da instalação e também toma o corpo do observador como elemento essencial para esses critérios de comparação entre tamanho da imagem e determinada experiência que se constrói nesses espaços. Para detalhar esses aspectos Sogabe levanta três principais situações que se instauram. No primeiro caso o ambiente composto por uma série de objetos é visto como um contexto único de relações que deve ser percorrido pelo espectador, tornando-o também elemento constituinte do espaço. As diferenças entre aquele espaço do observador e o espaço plástico da obra de que Aumont fala se diluem. Na segunda situação Sogabe pontua a entrada do vídeo na galeria, momento em que a imagem em movimento passa a ter destaque na atenção do público em meio a todos os objetos que também compõem o ambiente a ser percorrido, por meio dos aspectos esculturais do monitor de TV ou das projeções digitais. A atuação desse púbico ganha outro sentido na medida em que alguns desses trabalhos incorporam uma série de interfaces, como os sensores, que possibilitam que a atuação física modifique o conteúdo da imagem em movimento.

A terceira situação se instaura também principalmente a partir do advento da projeção digital e sua relação com mecanismos computacionais de interação, assim como acontece no segundo contexto citado. A diferença aqui reside no fato de que enquanto antes, na segunda situação, a imagem em movimento constituía um centro de atenção no ambiente na relação com outros objetos, que poderiam ser inclusive as próprias interfaces de interatividade, no terceiro momento o que ocorre é um esvaziamento da galeria em função da apresentação unitária da imagem em movimento em grandes proporções. Essa imagem passa a integrar outros mecanismos de interação. Enquanto antes o público era solicitado a interagir físicamente com as interfaces para a mudança da imagem em movimento a partir de ações como movimentar objetos e clicar em botões, agora o espaço vazio é dotado de interfaces que se diluem nessa e são quase invisíveis, a partir de sensores de presença, movimento ou temperatura, por exemplo. 

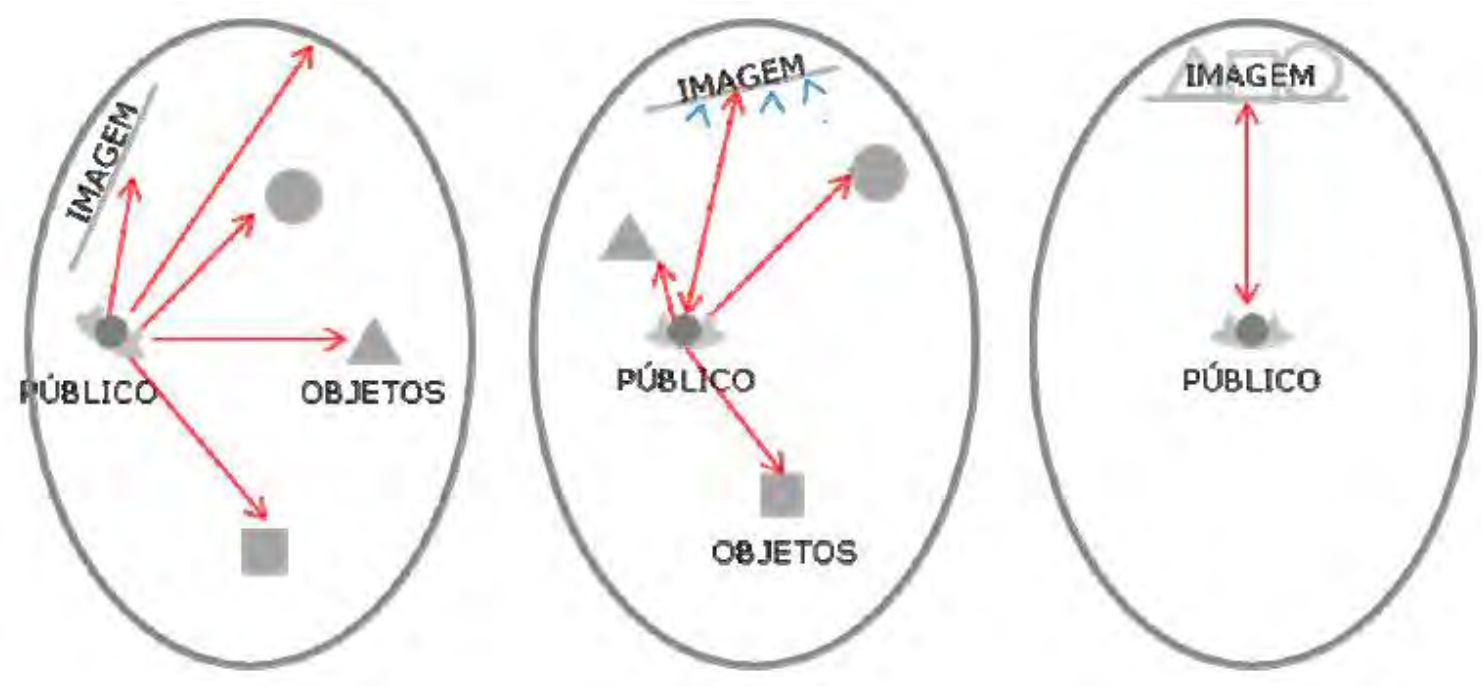

Figura 17: Diagramas das três situações encontradas na arte da instalação desde a década de 1970, de autoria de Milton Sogabe (2008)

Fonte: Artigo "O espaço das instalações: objeto, imagem e público", de Autoria de Milton Sogabe (2008).

As configurações apontadas por Sogabe são relevantes para compreender os mecanismos de problematização do espaço de instauração do vídeo. Importante acrescentar que essas três situações elencadas pelo autor não são historicamente localizadas. A análise dos trabalhos que se seguirão mostra claramente como essas situações, antes de terem se configurado como uma espécie de sobreposição, ou substituição uma da outra, na verdade coexistem na cena contemporânea que nos debruçamos, em trabalhos surgidos a partir da década de 1990 e principalmente nos anos 2000.

Como pensar então essa nova abordagem de arranjo espacial que se configura na galeria? Lev Manovich (2001) traz um importante conceito para a edificação de nossas análises, o da montagem espacial. Analisando passagens entre a prática cinematográfica e a linguagem computacional Manovich define a montagem espacial, de maneira geral, como a justaposição de uma série de imagens ao mesmo tempo na tela, que podem ser de diferentes tamanhos e proporções, e a narrativa se constrói também nessa outra lógica. $\mathrm{O}$ autor cita como exemplo a prática de utilização de janelas simultâneas (splitscreen) no cinema e as configurações de hiperlinks na linguagem computacional, onde nada precisa ser apagado e nem precisa ser esquecido ou retirado da tela como na montagem temporal de sequencialidade que o cinema costumou se valer em sua linguagem mais disseminada.

Manovich se foca aqui nas configurações daquilo que apontamos como a espacialização 
dentro do quadro pensando no formato mono-canal de apresentação do vídeo. Ao pensarmos a espacialização nos atemos, portanto, a essas questões levantas pelo autor como no âmbito de uma montagem espacial e ampliamos esse pensamento para os mecanismos de composição que se relacionam com o espaço físico de exibição. Elencaremos a partir daqui seis modos de espacialização que vieram à tona a partir das obras em vídeo que entramos em contato nos acervos estudados. Esses seis modos são abarcados por duas grandes operações de espacialização que, por sua vez, se diferenciam a partir daquele elemento levantado por Jacques Aumont, o tamanho da imagem. Salientamos que não temos aqui a perspectiva de criação de categorias de espacialização, num sentido paralisador que essa palavra pode trazer, mais sim o levantamento daquilo que Nöel Burch chamou dialéticas, pensando o vídeo no diálogo que é criado de maneira diferenciada dependendo da apropriação dos objetos, temporalidades e presenças que compõem seu espaço de exibição.

Para isso, elencamos duas operações de espacialização do vídeo que são formadas por diferentes modos de espacialização. Como operação entendemos essa organização sistemática como forma de pensamento de determinadas relações espaciais fundadas entre a obra e o público e aqui, mais uma vez, determinadas pelo tamanho da imagem em vídeo. Já os modos seriam as diversas maneiras de apresentação dessas duas operações. Os modos de espacialização seriam, portanto como as materializações plásticas desse pensamento espacial mais abrangente que compete às operações. Denominamos a primeira operação como microespacializações, formada pelos seguintes modos: vídeo-espaço, aparelho-espaço e vídeodistensão. A segunda operação denominamos macro-espacializações, com os seguintes modos correspondentes: situação-cinema, vídeo-cenário e vídeo-dilatação. $\mathrm{Na}$ continuidade desse trabalho nos preocuparemos, portanto, em delimitar do que se tratam essas operações e modos de espacialização, apontando suas características e exemplificando-as a partir de algumas obras.

\subsection{PRIMEIRA OPERAÇÃO: MICRO-ESPACIALIZAÇÕES}

A primeira operação traz em seu cerne uma situação fundante, as problematizações do espaço dentro do quadro da imagem do vídeo e algumas extensões de sua narrativa a partir do espaço plástico da imagem em direção ao espaço concreto, agregando elementos que estão dispostos nas galerias ao lado ou ao redor da tela de vídeo. Nessa operação o artista edifica situações em que o corpo do espectador encontra-se em certa condição de superioridade com relação ao tamanho da imagem em vídeo apresentada. Estamos falando, portanto, na 
apresentação desses vídeos em monitores e objetos de pequenas proporções, que são pensados em uma unidade onde o corpo do espectador consegue apreendê-los em uma única tomada de visualização quando se encontra no espaço em que a obra está instalada.

Nessa operação o formato das obras aponta para um certo de teor de proximidade e intimidade com a presença desse corpo. Os trabalhos são geralmente apresentados em formatos para serem exibidos acoplados ao espaço bidimensional da parede da galeria ou também de forma escultural, em que o espectador pode rodeá-la na qualidade de objeto, ou ainda agregam essas duas abordagens a partir do monitor de vídeo disposto na parede e a presença de objetos diversos instalados nas proximidades e que integram a narrativa do vídeo. Portanto, no âmbito das pequenas dimensões a micro-espacialização traça um percusso de espacialização da imagem videográfica (vídeo-espaço), essa imagem se espacializa em outra situação por meio do próprio monitor de vídeo (aparelho-espaço), e imagem e monitor se espacializam então na inclusão de extensões, objetos que são instalados junto ao monitor (vídeo-distensão), conforme diagrama disponibilizado abaixo:

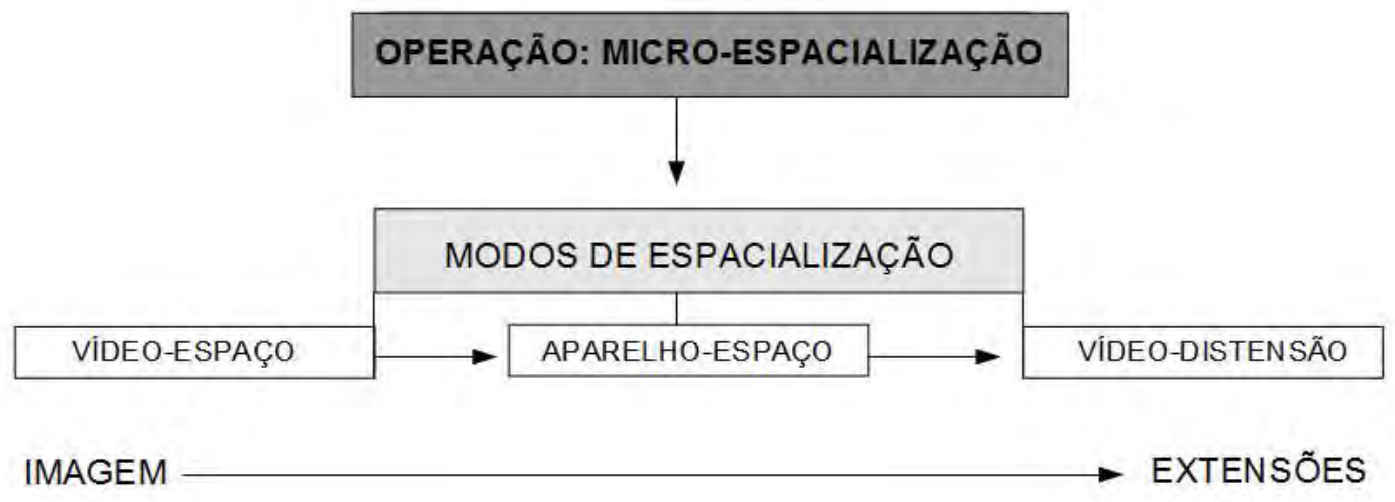

Figura 18: Diagrama da micro-espacialização

\subsubsection{PRIMEIRO MODO: VÍDEO-ESPAÇO}

No primeiro modo de espacialização a principal questão a ser discutida é a da montagem espacial de que fala Lev Manovich e que Phillipe Dubois, como já vimos, prefere nomear como uma mixagem das imagens. Nesse modo de espacialização o artista se utiliza de mecanismos diversos da linguagem eletrônica/digital para questionar o quadro em seus limites e segmentos 
de espacialidade, confere atenção especial a questão do descentramento, a fuga da perspectiva linear, a importância dada às bordas, naquele movimento de tentativa da apresentação simultânea de imagens dentro do mesmo quadro videográfico e que materializaria aquilo que Nöel Burch chama uma dialética da imagem como fator essencial. O processo se dá, portanto, a partir do arranjo dos quadros dentro do quadro, da inserção de imagens umas nas outras.

Apontemos, portanto, como essas questões específicas aparecem em alguns trabalhos contemporâneos de vídeoarte. Uma primeira relação espacial que gostaríamos de elencar é a que se refere à dialética entre imagem e som, que parece surgir nesses trabalhos no âmbito da descontinuidade entre um e outro. Tomamos como exemplo Getting Out (1984) de Rafael França ${ }^{1}$. Na obra uma mulher após acordar de um sono profundo aparece realizando ações de embate com um ambiente doméstico e o áudio que ouvimos não corresponde a essas ações exibidas. O vídeo inicia com processos de sincronia desse áudio no momento em que a personagem tenta abir uma porta e força sua maçaneta várias vezes, emergindo um ruído que toma conta do vídeo como uma metáfora do desespero que vemos a personagem atuar. Esse processo integra, por exemplo, o aparecimento daquele segmento de espacialidade que Burch aponta como existente por trás do cenário e que parece essencial para a narrativa desse vídeo, já que a personagem parece estar presa nesse ambiente e a tentativa de saída nos remete a consciência desse espaço fora do quadro, que não é o contra-campo, como uma possibilidade de modificação da situação que é apresentada e desenvolvimento da relação entre a mulher e o espaço.

Ao longo do vídeo essa mulher caminha pelo ambiente doméstico e o que ouvimos é a acumulação de uma série de ruídos. O barulho da maçaneta da porta, o barulho de pés caminhando no chão, uma trilha de suspense se justapõem e não correspondem necessariamente às ações que visualizamos na imagem. Aqui percebemos, portanto, essa justaposição do áudio na mesma relação que a justaposição das imagens em outros trabalhos se desenvolverá. Essa acumulação de certa maneira retira de nós uma referência da localização espacial da personagem e desestrutura uma abordagem de casualidade da narrativa, na medida em que as ações parecem se destacar em uma temporalidade que se expande por todo o vídeo. Enquanto caminha, esse som em off da maçaneta que ouvimos simultaneamente nos rememora então outro quadro já apresentado no vídeo e materializa pelo som aquela tentativa de não apagamento ou esquecimento do quadro anterior, evocando também um espaço off. Essa situação poderia ser

1 Nasceu em 1957 na cidade de Porto Alegre e faleceu em 1992. Estudou na Escola de Comunicações e Artes da Universidade de São Paulo, passando também por período de estudo em Chicago, Estados Unidos. Integrou o grupo 3NÓS3 e trabalhos com práticas em reprodução gráfica, fotografia, vídeos e videoinstalações. 
compreendida também pelo que Timothy Barker (2012) aponta como a capacidade da utilização dessas mídias em re-apresentar o tempo em múltiplas escalas do passado que podem se sobrepor.

O som é, portanto, o principal responsável pela instituição de uma quebra da lógica narrativa sequencial. Em certo momento do vídeo a imagem em movimento é formada a partir de congelamentos convertidos em imagens fixas que se complementam para a apresentação de um certo clímax da narrativa, o momento em que a personagem em um ato de desespero liga o forno de sua cozinha, mantendo-o aceso, e insere dentro deste um papel com fogo, que logo remete à possibilidade de explosão daquele espaço. As imagens fixas utilizadas direcionam uma certa desaceleração da apresentação dessa espacialidade, existente na relação dúbia entre a tensão da possibilidade de explosão e os movimentos lentos de transição entre essas imagens fixas, que por sua vez se opõem aquela àquela espacialidade frenética obtida pelo acúmulo dos ruídos no início do vídeo.

A tensão da presença da mulher no ambiente é quebrada no momento em que a vemos saindo da casa, para em seguida ouvirmos um barulho de explosão que serve como gancho para a aparição de uma imagem desestabilizada, tremida, da personagem correndo pelas ruas e que remete ao ambiente doméstico que agora é um espaço fora do quadro. O trabalho de França é exemplar para pensarmos como o som também atua nesses processos de espacialização, e veremos como essas questões apontadas nessa obra irão compor vários dos trabalhos analisados aqui, seja na relação com o quadro ou nos aspectos instalativos.

Esses trabalhos caminham em conjunto para a apresentação de uma simultaneidade de elementos, entre imagem e som, que apresentados no quadro desestabilizam uma noção de localização espacial específica para exibir várias espacialidades a partir de algumas técnicas. Uma dessas técnicas é a da sobreimpressão, a sobreposição de uma ou mais imagens sobre as outras. Esse mecanismo se vale da transparência das imagens para de certa maneira fundi-las no mesmo quadro, conferindo um certo aspecto de diluição.

Nesse sentido, essas imagens sobrepostas atuam em conjunto no processo de supressão e revelação umas das outras. Essa técnica é utilizada, por exemplo, na obra Barrueco (2004) de Ayrson Heráclito ${ }^{2}$ e Danillo Barata. Segundo Heráclito o vídeo traça discussões a respeito

2 "É artista, curador e professor. Mestre em Artes Visuais pela Universidade Federal da Bahia (UFBA), e doutorando em Comunicação e Semiótica na Pontifícia Universidade Católica de São Paulo (PUC-SP). Trabalha com instalação, performance, fotografia e vídeo, em obras que lidam com elementos da cultura afrobrasileira. Participou de coletivas como Afro-Brazilian Contemporary Art, Europalia.Brasil, Bruxelas, Bélgica (2012); Trienal de Luanda, Angola (2010); e MIP 2, Manifestação Internacional de Performance, Belo Horizonte (2009). Vive e trabalha em Salvador, Bahia". Fonte: www.videobrasil.org.br 


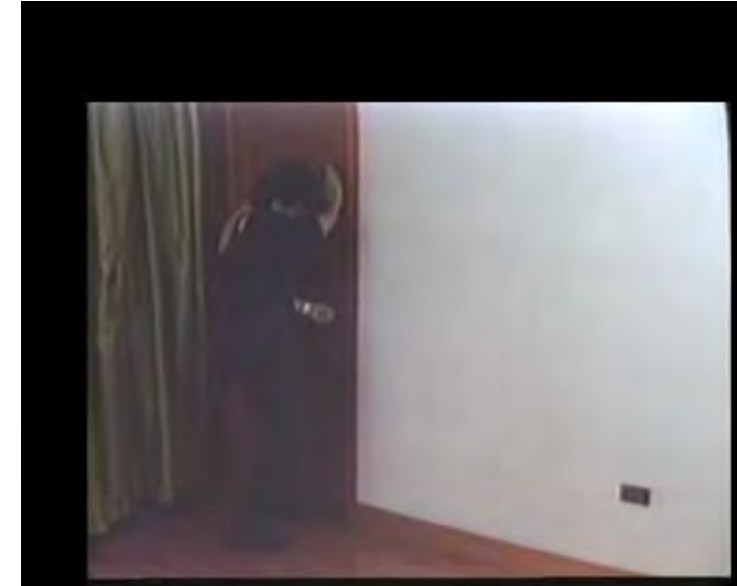

$1^{\prime} 09^{\prime \prime}$

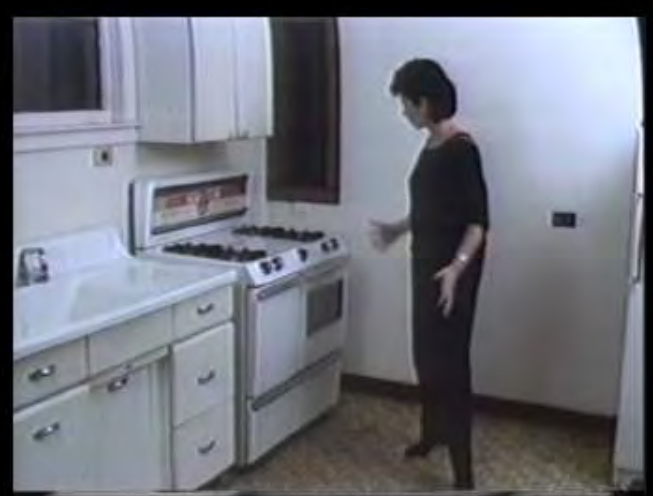

$1 ' 26^{\prime \prime}$

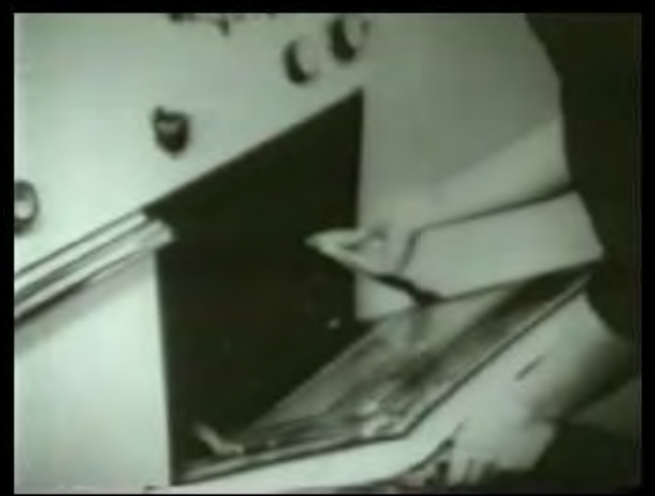

$2^{\prime} 57^{\prime \prime}$

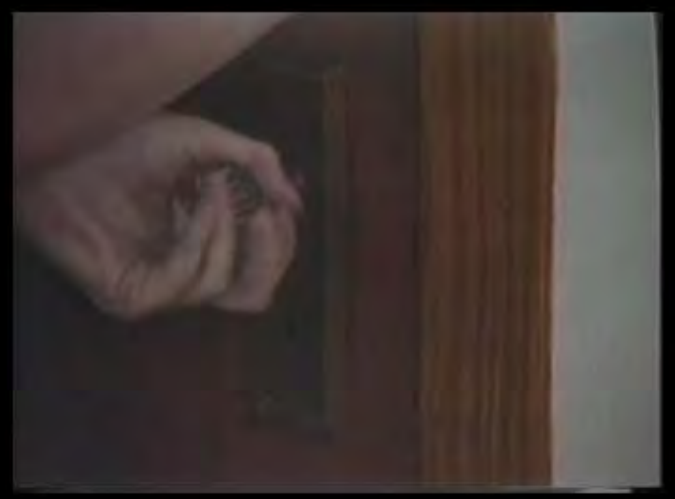

$1^{\prime} 11^{\prime \prime}$

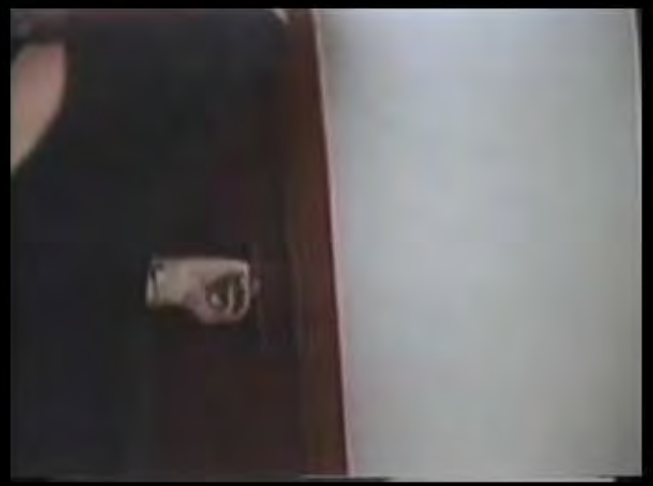

$2^{\prime} 21^{\prime \prime}$

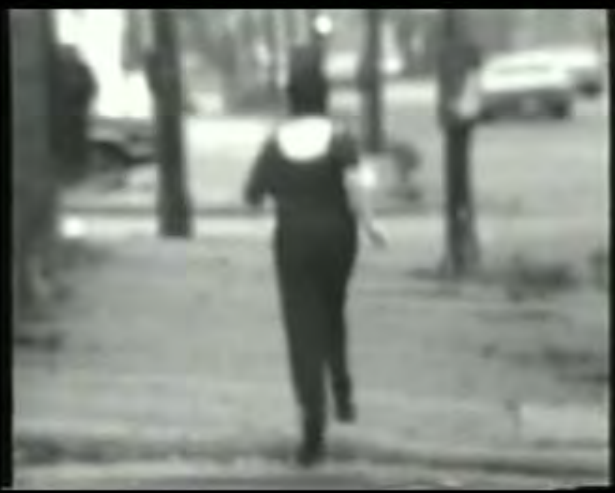

$3^{\prime} 40^{\prime \prime}$

Ilustração 19: Frames do vídeo Getting Out (1983) de Rafael França Fonte: Acervo da Associação Cultural Videobrasil 
de uma beleza impura, não clássica, no âmbito da mestiçagem da cultura brasileira, dando um enfoque especial às configurações que se construíram a partir da vinda de africanos para o Brasil, discussão essa materializada no próprio título do trabalho, Barrueco, que ainda segundo o artista se refere a pérolas imperfeitas.

Nesse sentido, essas imagens sobrepostas atuam em conjunto no processo de supressão e revelação umas das outras. Essa técnica é utilizada, por exemplo, na obra Barrueco (2004) de Ayrson Heráclito ${ }^{3}$ e Danillo Barata.Segundo Heráclito o vídeo traça discussões a respeito de uma beleza impura, não clássica, no âmbito da mestiçagem da cultura brasileira, dando um enfoque especial às configurações que se construíram a partir da vinda de africanos para o Brasil, discussão essa materializada no próprio título do trabalho, Barrueco, que ainda segundo o artista se refere a pérolas imperfeitas. Os artistas instituem, a partir do pensamento de Paul Gilroy $^{4}$ o “(...) o oceano Atlântico como útero gestor de uma categoria racial negra a partir do tráfico negreiro"5. O vídeo é ainda integrado por uma trilha sonora com a música Black is the color (1959) interpretada por Nina Simone, e pelo poema Divisor de Mira Albuquerque, que acompanha a abordagem do vídeo em passagens como "Eu sou vítima do terrível crime da escravidão. " e "Mergulhamos num flagelo do Atlântico". Em sua pesquisa, Heráclito utiliza algumas materialidades importantes como o azeite de dendế ${ }^{6}$, que aparecerá como elemento fundamental na materialização dessa parceria com Danillo Barata.

$\mathrm{O}$ vídeo inicia com a imagem de uma quantidade de azeite de dendê que se movimenta pelo quadro formando ondas e é sem seguida sobreposto à imagem de um torso masculino negro usando um colar de pérolas que expele também esse líquido e o derrama sobre o corpo apresentado, em seguida substituído por uma reprodução da pintura Navio Negreiro (1840) de Willian Turner ${ }^{7}$, que por sua vez também se dilui em sobreimpressão, onde três imagens

3 "É artista, curador e professor. Mestre em Artes Visuais pela Universidade Federal da Bahia (UFBA), e doutorando em Comunicação e Semiótica na Pontifícia Universidade Católica de São Paulo (PUC-SP). Trabalha com instalação, performance, fotografia e vídeo, em obras que lidam com elementos da cultura afrobrasileira. Participou de coletivas como Afro-Brazilian Contemporary Art, Europalia.Brasil, Bruxelas, Bélgica (2012); Trienal de Luanda, Angola (2010); e MIP 2, Manifestação Internacional de Performance, Belo Horizonte (2009). Vive e trabalha em Salvador, Bahia". Fonte: www.videobrasil.org.br

4 É professor de Literatura inglesa e americana no King's College London. Sua área de pesquisa está relacionada aos estudos pós-coloniais, melancolia pós-imperial, literatura e políticas culturais da descolonização europeia, história cultural e intelectual afro-americana, formação e reprodução de identidades nacionais especialmente no que se refere a identidades étnicas. Autor do livro $\mathbf{O}$ atlântico negro, que busca uma definição da modernidade através do conceito de diáspora negra. Fontes: www.kcl.ac.uk / www.editora34.com.br.

5 Trecho de depoimento de Ayrson Heráclito retirado da página da obra na Plataforma VB, serviço online da Associação Cultural VideoBrasil. Disponível em: www.plataforma.videobrasil.org.br.

6 Óleo retirado do dendezeniro, palmeira originária da costa oriental da África e largamente cultivada na região sudeste da Bahia, Brasil.

7 "Joseph Mallord Willian Turner (1775 -1851) foi um inglês, pintor de paisagens, aquarelista e gravurista, cujo estilo pode ser compreendido como a base para o surgimento do Impressionismo". Fonte: www.willianturner.org 


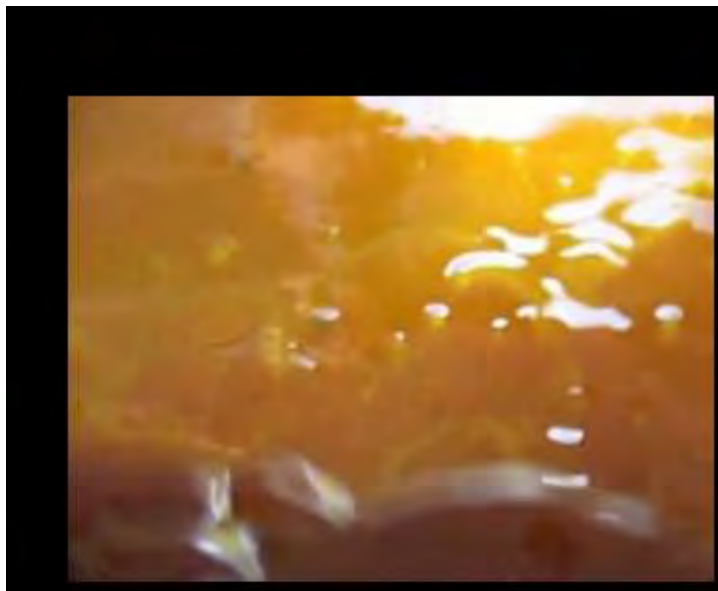

$08^{n}$

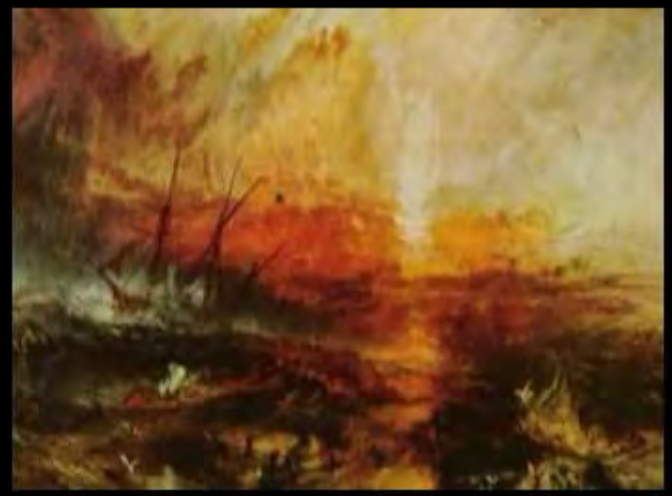

$20^{n}$

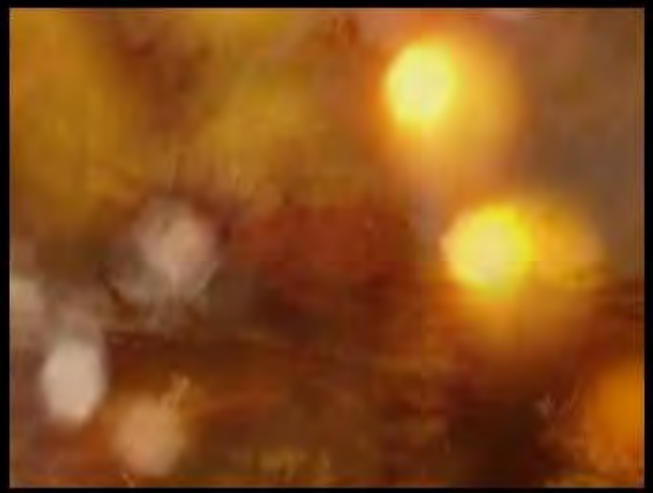

$27^{\prime \prime}$

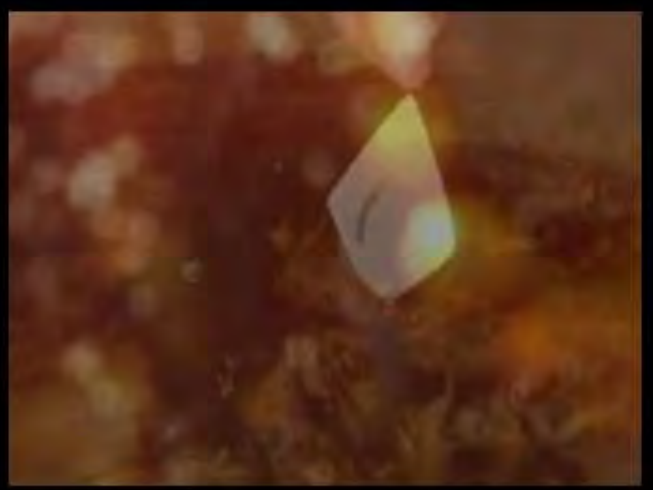

Eu sou vitima do terrivel crime

da escravidăo.

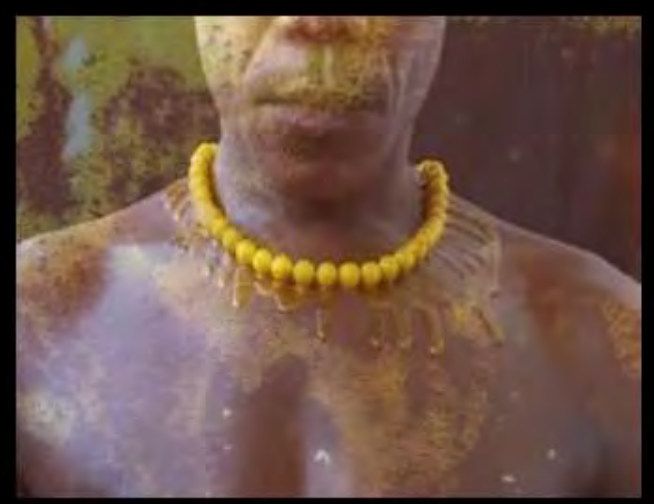

$2^{\prime} 06^{n}$

$3^{\prime} 39^{\prime \prime}$

Ilustração 20: Frames do vídeo Barrueco (2004) de Ayrson Heráclito e Danillo Barata Fonte: Acervo da Associação Cultural Videobrasil 
parecem existir simultaneamente: a pintura, o azeite de dendê que se movimenta e aquele colar de pérola, antes no torço do performer, e agora mergulhado em dendê. O vídeo inteiro é atravessado por interrupções em tela negra que trazem os versos do poema citado anteriormente. Após a primeira interrupção em tela negra, um outro elemento surge, a imagem de uma arraia, que para Heráclito é como uma metáfora de liberdade no oceano Atlântico.

No vídeo, essa diluição de uma imagem na outra acontece em dois momentos, no primeiro o reflexo do performer que visualizamos nesse líquido que perpassa toda a narrativa e evoca, portanto, um contra-campo, e em segundo nesses processos de sobreimpressão técnica das diferentes gravações. Essas sobreimpressões parecem metaforizar para além da dissolução das imagens uma unificação e coexistência dos elementos plásticos apresentados, em uma ordem de construção simbólica da mestiçagem da cultura negra e da existência essencial desse processo na própria cultura brasileira. A potência maior dessa estrutura de sobreimpressão na metaforização dessas questões surge para nós nos últimos segundos do vídeo, em que um zoom out revela novamente o torso do performer usando o colar de pérolas, que havia sido banhado em dendê, derramando essa materialidade sobre o seu corpo. Esse corpo está agora completamente diluído no quadro à imagem do dendê em movimento que parece simular um mar, o dendê como própria metáfora do atlântico.

Essa técnica de sobreimpressão possibilita mais uma abordagem da apresentação simultânea de espacialidades dentro do quadro. Outro mecanismo recorrente é o que na linguagem audiovisual se chama splitscreen, o que Phillipe Dubois (2004) tratará como um jogo de janelas. Segundo o autor, essa prática de espacialização do vídeo trata-se da divisão do quadro único do vídeo, que toma toda a extensão do monitor, em dois ou mais quadros no formato de janelas, que apresentam acontecimentos diferentes mas aparecem simultaneamente. Essa situação se caracteriza por uma divisão muito bem delimitada por parâmetros geométricos que geralmente aparecem em formato de retângulos, simulando as delimitações espaciais das bordas do próprio quadro. O retângulo, apesar de mais comum, é apenas uma das possibilidades para a construção dessa relação, que também podem se manifestar por uma variedade de outras formas geométrica, como triângulos e círculos, um ao lado do outro ou um em cima do outro.

Esse mecanismo é algo que algumas obras produzidas em película já utilizavam, como no famoso filme Chelsea Girls (1966), dirigido por Andry Warhol e Paul Morrisey, que apresenta uma tela dividida ao meio a partir de duas janelas, uma colorida e outra preto e branco, que se complementam narrativamente. No entanto, nas práticas de videoarte esse jogo de janelas parece ganhar um ar ainda mais anárquico ao instituir a essas um movimento constante que desintegra o quadro não apenas pela duplicação ou multiplicação das janelas que aparecem 
simultaneamente, mas por se modificarem em tamanho, formato e posição no quadro várias vezes ao longo do vídeo, momentos em que uma janela pode invadir e sobrepor a outra, inclusive utilizando mecanismos como a sobreimpressão para a realização dessas transições.

Trabalhos como Fast/Slow_Scapes (2006) Giselle Beiguelman ${ }^{8}$ apresentam uma série de imagens de viagem gravadas em locais diferentes e divididas em sete capítulos. Nos dois primeiros capítulos, intitulados carscapes (sp.br) e tunnelscapes (Imigrantes Rd.), vemos vídeos em uma série de quadros que se intercalam num movimento vertical na tela, divididos por uma faixa preta que nos remete à materialidade da película e seu processo de projeção. No terceiro capítulo, cabscapes (nyc) essas faixas pretas desaparecem e conferem uma unidade ainda maior entre esses vídeos que vão se intercalando, além de serem substituídos de maneira mais veloz. Essas imagens são embutidas de uma espécie de continuidade gerada pela posição de elementos como as linhas dos prédios exibidos, que são apresentados diagonalmente e se conectam, dando-nos uma impressão de entrada do motivo de um quadro no outro mesmo que isso de fato não aconteça em função da clara linha que os divide. Essa questão vai perpassar grande parte do capítulo, uma espécie de ambiguidade entre a queda de um quadro sobre o outro que lhe substitui e que, ao mesmo tempo, servirá como amparo para o quadro seguinte. O último momento, um congelamento da imagem, salienta a transição entre os quadros e a espera pela próxima imagem que o substituiria, mas que não chega a ser exibida, o movimento é interrompido para o início do próximo capítulo. O áudio aqui acompanha a velocidade de substituição dos quadros, uma espécie de música eletrônica em ritmo acelerado.

No quarto capítulo, nomeado railscapes (berlin), um processo de sobreimpressão entre os quadros se intensifica, diluindo aquela linha que os separava. Vemos ainda a utilização de imagens em preto e branco que conferem um ar de retomada de memórias de uma cidade, e por meio dessas sobreimpressões citadas prédios se confundem com as imagens de pessoas a partir de uma viagem de trem. Verificamos também a mesma sensação de queda em função de alguns posicionamentos diagonais das imagens acompanhadas ainda por um áudio eletrônico.

No quinto capítulo uma situação diferente se instaura, os quadros passam a ser substituídos na tela em um movimento vertical, retomam aquela característica de uma espécie de metáfora do movimento da película no aparelho de projeção, inclusive pelo retorno dos

8 "É artista, pesquisadora e professora universitária. Seu trabalho inclui intervenções em espaços públicos, projetos em rede e aplicações para dispositivos móveis. Sua prática artística e intelectual se baseia em uma abordagem crítica das mídias digitais e de seus sistemas de informação. É professora da Faculdade de Arquitetura e Urbanismo da Universidade de São Paulo, onde se dedica às áreas de preservação da arte digital, do patrimônio imaterial e do design de interface. É graduada e doutora em História Social pela Faculdade de Filosofia, Letras e Ciência Humanas (FFLCH) da USP.”. Fonte: www.videobrasil.org.br 
intervalos negros entre as imagens, que vão aos poucos sumindo para dar lugar a uma colagem entre as extremidades de cada quadro. Aqui as imagens são exibidas de modo muito mais lento e identificamos a existência inicial de uma motocicleta percorrendo uma estrada que impõe o surgimento de uma perspectiva, reforçada pelo aparecimento posterior de outros automóveis e pela barragem lateral da estrada. Essa perspectiva, que sugere uma entrada em profundidade no quadro é o tempo inteiro interrompida espacialmente pela substituição vertical desses mesmos quadros com o intuito de voltarmos a nossa atenção especialmente para a natureza de movimento entre quadros encontrada na imagem. O áudio aqui já é muito mais sereno, acompanhando a movimentação de transição mais lenta entre as imagens.

Nos últimos capítulos, vanscapes (belo horizonte) e boatscapes (atenas/paros), as imagens são apresentadas ainda de maneira mais lenta, com o retorno no último capítulo daqueles intervalos pretos que dividem as imagens e a partir de substituições horizontais dos quadros. Ainda nesse capítulo uma tensão espacial parecida com a do vídeo Eko Kahny (2012) de Lucina Magno se estabelece. Imagens de barcos apresentadas diagonalmente, como se estivessem naufragando, desafiam o segmento de espacialidade que corresponde à base da imagem. Nesse mesmo jogo com janelas, o trabalho Radicais Livre/os (2007) de Marcus Bastos $^{9}$ expande essa atuação para a deformação constante dos quadros que se intercalam.

Nesse trabalho Bastos problematiza questões relacionadas a liberdade em diferentes contextos da história do Brasil, passando pela ditadura militar e abordando questões sociais, sexuais, de trabalho, software livre, no que o autor diz ser uma espécie de pesquisa de linguagem documental na era digital. $\mathrm{O}$ vídeo inteiro é formado por um jogo de janelas que entram e saem do quadro em uma velocidade acelerada, cortam a tela horizontalmente e verticalmente, se sobrepõem e alternam entre entrevistas e capturas urbanas da rua e de prédios. Os depoimentos falam sobre a relação desses personagens com histórias de repressões e se dão de modo descontínuos, os quadros de cada um dos depoentes surgem e são interconectados por outros depoimentos ao longo do vídeo, uma espécie de colagem de várias vozes dentro de cada uma dessas janelas que constrói uma narrativa fragmentada.

9 "É artista, curador e pesquisador nas áreas de convergências entre audiovisual, design e novas mídias. Ele é doutor em Comunicação e Semiótica pela PUC-SP, onde trabalha desde 2003. É autor do e-book Cultura da Reciclagem (2007) e um dos editores de Apropriações do (In)comum: espaço público e privado em tempos de mobilidade (2009). Editou, com Lucas Bambozzi e Rodrigo Minelli, o livro Mediações, Tecnologia, Espaço Público - Um panorama crítico da arte em mídias móveis (2010). É curador do VIVO arte.mov Festival Internacional de Arte em Mídias Móveis, desde 2007’. Fonte: www.videobrasil.org.br 


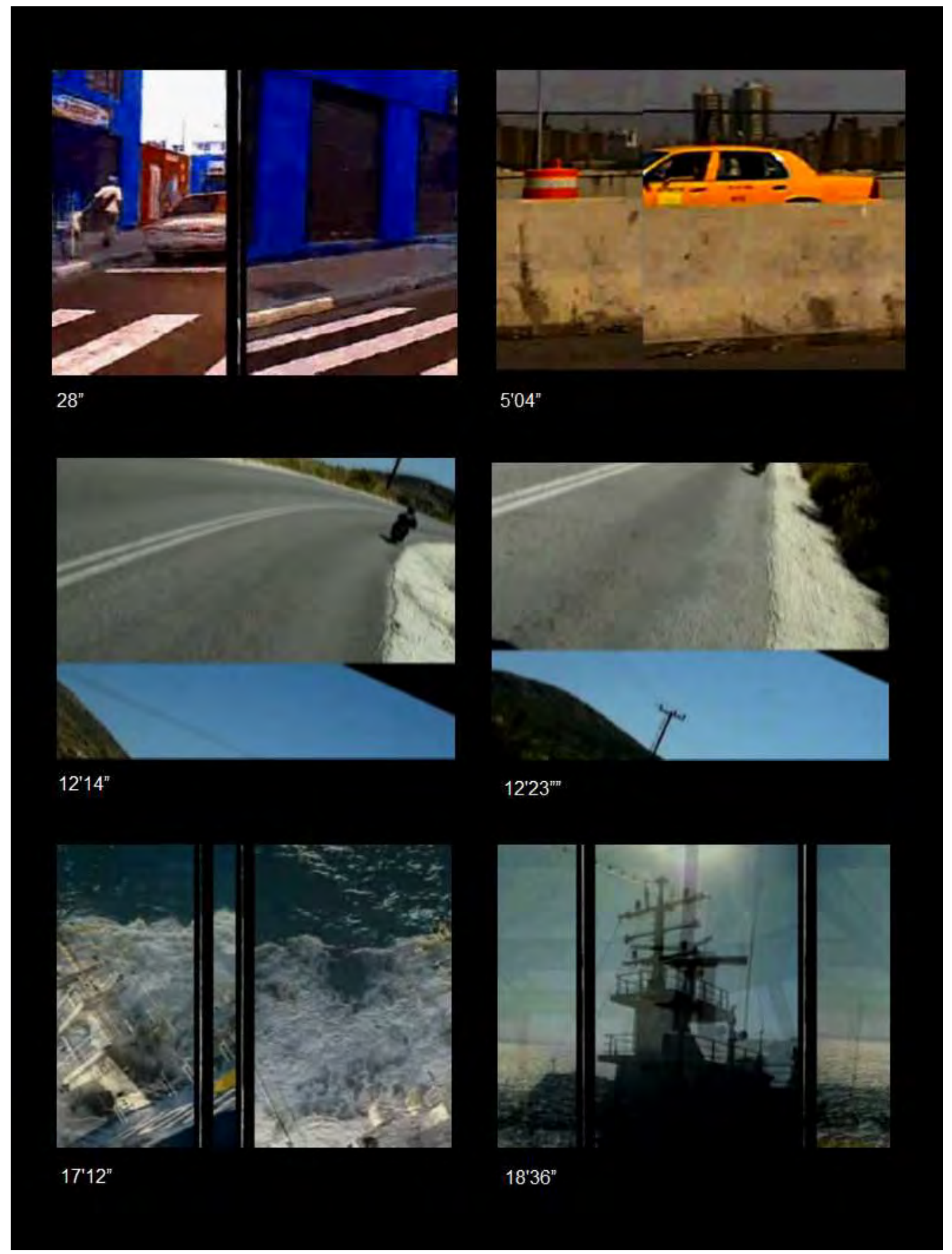

Ilustração 21: Frames do vídeo Fast / Slow_Scapes (2006) de Giselle Beiguelman Fonte: Acervo da Associação Cutural Videobrasil 


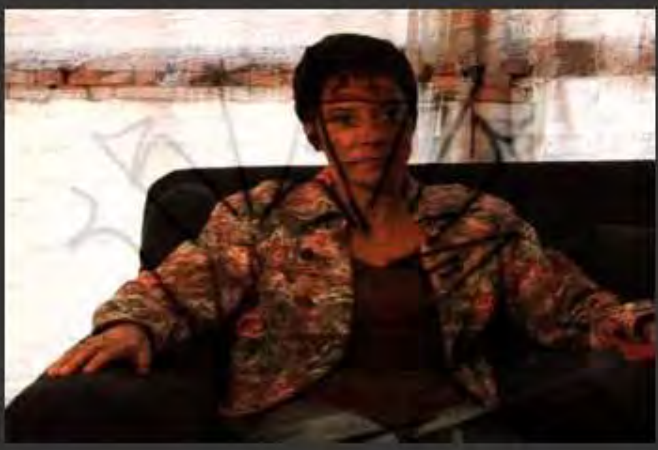

$40^{\prime \prime}$

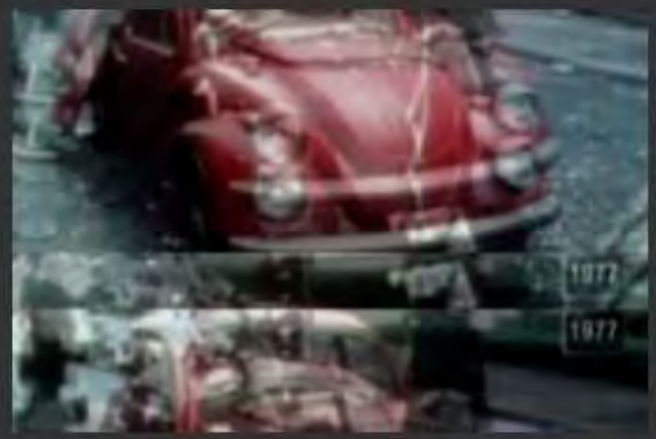

$1^{\prime} 40^{n}$

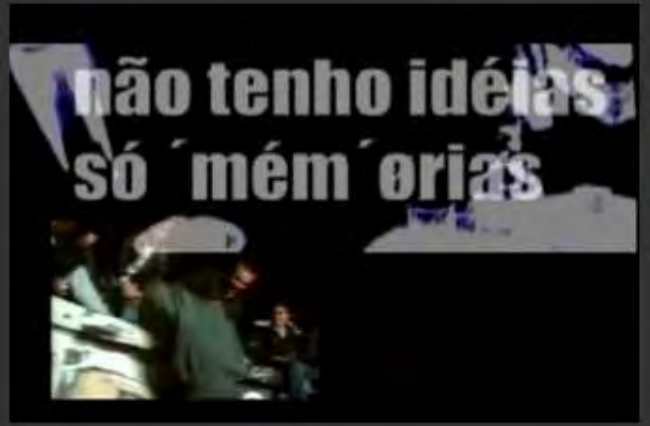

$7^{\prime} 39^{\prime \prime}$

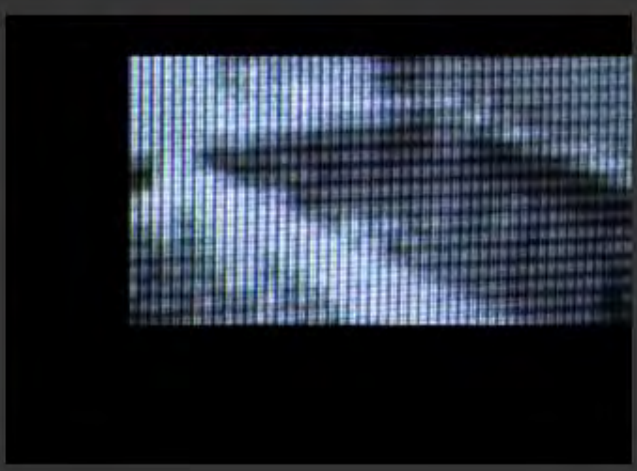

$1 ' 27$

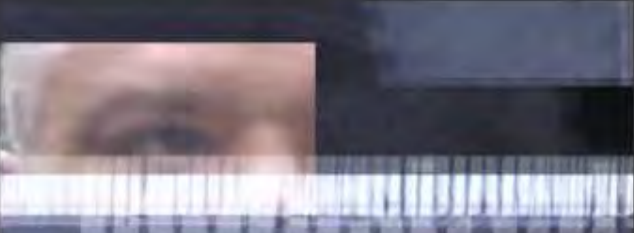

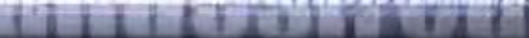

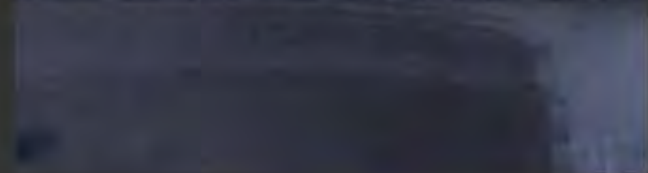

$6^{\prime} 55^{\prime \prime}$

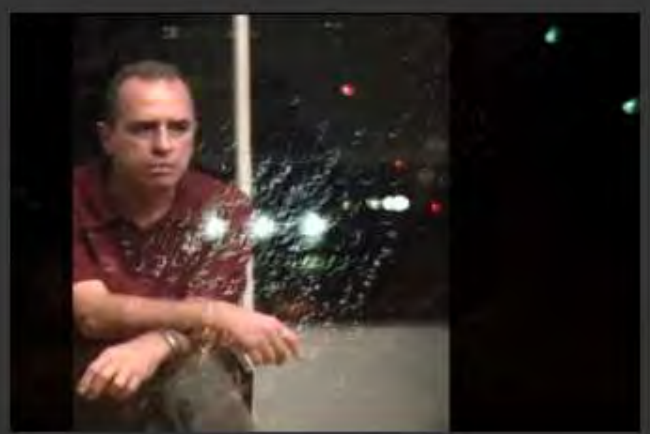

$10^{\prime} 03^{n}$

Ilustração 22: Frames do vídeo Radical Livre/os (2007) de Marcus Bastos Fonte: Acervo da Associação Cutural Videobrasil 
Essa velocidade dos quadros parece materializar o desaparecimento dessas histórias e a condição frágil da própria concepção de liberdade que engendra o vídeo, exemplificado por histórias de desaparição como as de Crimélia Souza, que reclama a falta dos registros de sua luta durante a ditadura militar. Ainda algumas frases sobre um fundo negro intercalam essa movimentação das imagens como uma espécie de respiro entre os espaços do quadro, entre elas “a linguagem é o meio mais forte do Outro - alojado em nós mesmos" (Paul Valéry). Bastos, apesar de utilizar esses quadros em seus formatos geométricos, com linhas bem definidas que os separam consegue se distanciar de uma certa situação estática que essa característica poderia conferir ao quadro. Em vez disso, ao trabalhar essas trocas, aparecimento e desaparecimento das janelas o artista dota o video de uma dinamicidade que solicita do público uma atenção redobrada na captura dessas imagens. Essa visualização completa é, no entanto, uma alternativa quase impossível de ser realizada, e aqui Bastos materializa de forma exemplar uma certa espacialização da narrativa, que não acontece de modo linear e, portanto, só pode ser apreendida por meio de seus fragmentos que se intercalam espacialmente.

Esses trabalhos configuram, portanto, uma utilização desse jogo de janelas que se movimentam no quadro, e não apenas o divide. Nessa situação habita uma vontade de desestabilização contínua do centramento do assunto da obra, a utilização das bordas da imagem para a ocupação do quadro inteiro como homogeneamente importante, e se dá pela simultaneidade do aparecimento das janelas, como no vídeo de Bastos, ou pela transição acelerada dos quadros, presente em ambas as obras.

Por fim, uma última prática importante para pensarmos essas questões de espacialização dentro do quadro é aquela que Dubois chama incrustação, que está também no âmbito da inserção de uma imagem na outra assim como a sobreimpressão, mas por outro viés, configurando-se basicamente pela técnica que conhecemos como Chroma-Key. Para Dubois esse processo consiste em uma:

(...) separação no sinal de vídeo, entre uma parte da imagem e outra segundo um tipo de frequência da crominância ou da luminância. Esta parte do sinal, que corresponde na realidade visual a tal tipo de cor ou de luz, é separada do restante, posta de lado nas máquinas, criando assim um "buraco eletrônico" na imagem, que pode então ser preenchida por uma parte correspondente de outra imagem que nele se embute. (DUBOIS, 2004, p. 82).

Entre nossos objetos de estudo o vídeo Ressonar Insular (2013) de Breno Filo ${ }^{10}$ é um

10 "Pesquisador, designer e artista, é mestrando em Artes pela UFPA, graduadoem Artes Visuais pele UFPA e técnico em Design pelo Instituto Federal de Educação Tecnológica do Pará (IFPA). Suas linhas de investigação envolvem design instrucional, intervenção midiática no ensino de arte, poéticas em arte conceitual, artepolítica, memória e imaginário amazônida” Fonte: http://lattes.cnpq.br/8375143970857162. 


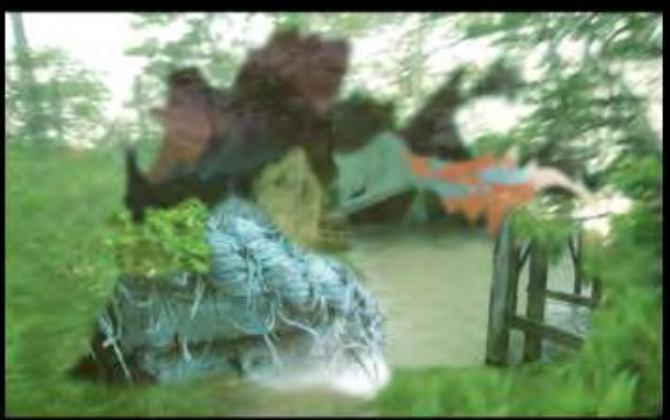

$1^{n}$

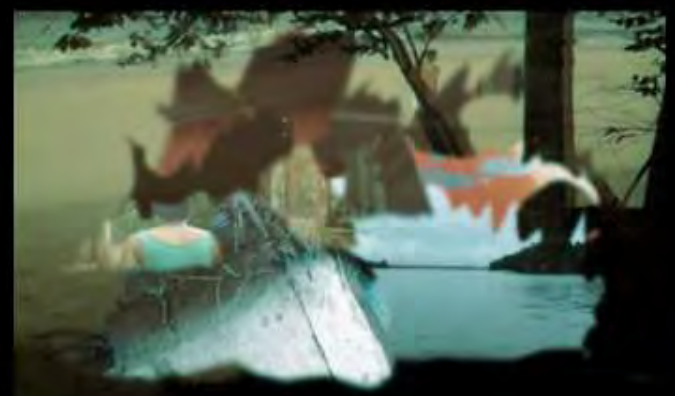

$22^{n}$

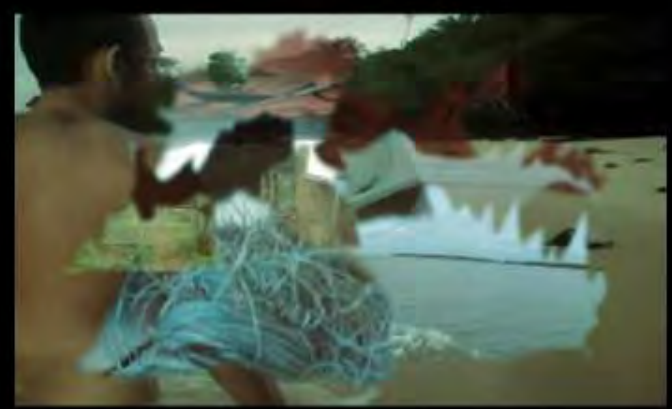

$1^{\prime} 24^{\prime \prime}$

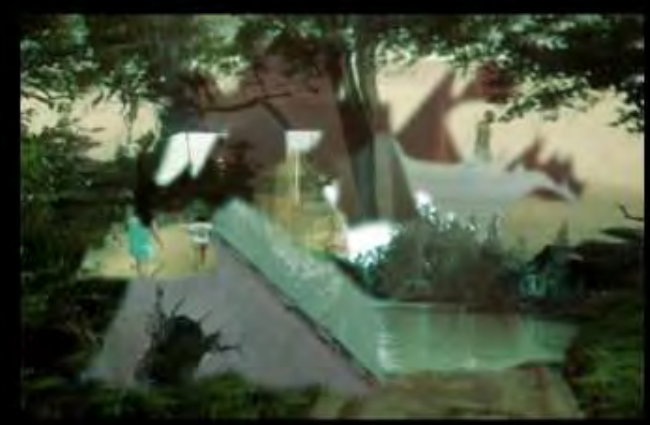

$10^{\prime \prime}$

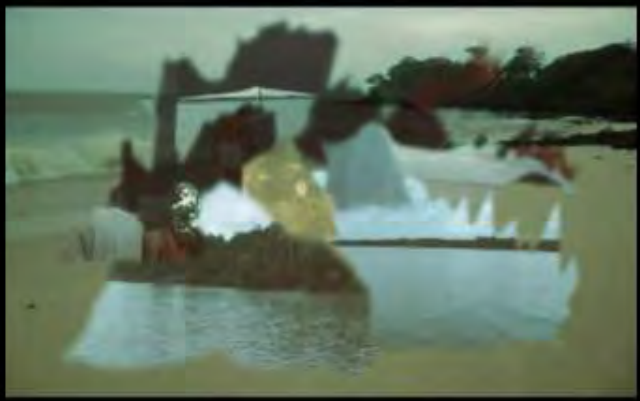

$37^{\prime \prime}$

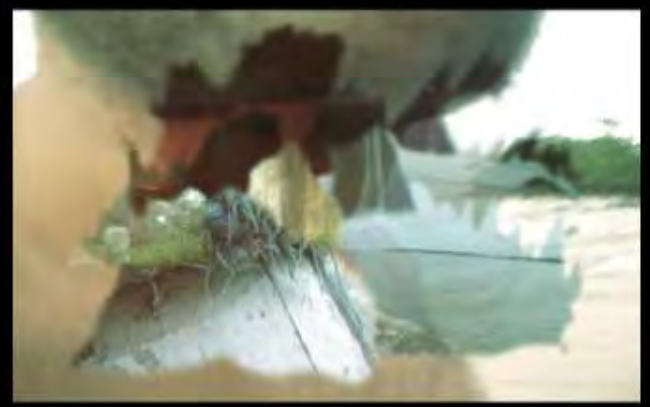

$1^{\prime} 26^{n}$

Ilustração 23: Frames do vídeo Ressonar Insular (2013) de Breno Filo

Fonte: Acervo do projeto de pesquisa "Acervo de Videoarte paraense: sistematização e análise crítica" (CNPq/SEC/MinC - 2014-2016). 
exemplo de utilização desse mecanismo. Nesse trabalho o artista desenha uma espécie de mapa afetivo das relações criadas com as ilhas que visitou na Amazônia, como a ilha de Cotijuba, mapa esse construído visualmente a partir dessas inserções de imagens umas nas outras de que estamos falando. O que vemos é uma série de fragmentos de vídeos que coexistem no quadro a partir dessas espécies de janelas aqui configuradas por formas ameboides. Cada uma dessas formas, criadas em computador, foi embutida de um padrão de cor diferenciado para que pudessem assim ser ligadas no programa de edição digital ao seu respectivo vídeo, que passa então a ser apresentado nesses formatos por um processo de recorte espacial desses fragmentos de imagem em movimento. Os vários quadros aparecem como um desenho que deforma as bordas dessas imagens inseridas para lhes conferir essa impressão de vaguear pela imagem, uma tentativa de aproximação da própria noção de mapa como o de descoberta de percursos espaciais orientadas aqui por uma ação poética.

Essa técnica permitiu então imbuir o vídeo de uma fragmentação das janelas que podem ser apresentadas. As imagens que o constituem são gravações de caminhadas na areia, tomadas do céu, tomadas de uma linha do horizonte que fundam uma paisagem que se apresenta na tela a partir de um movimento quase cíclico. No vídeo verificamos a edificação de uma espécie de relação figura-fundo entre tomadas de uma caminhada pela paisagem que tomam o quadro inteiro (fundo), e a intervenção dessas formas ameboides sobre esse fundo. Essas últimas parecem flutuar e constituir um certo centramento dessa fragmentação no quadro, tornando as bordas uma espécie de elemento de estabilização e reforço desse centro visual que é, no entanto, também móvel. O áudio do vídeo também rememora essas questões de espacialidade pela utilização de samples de músicas de Brian Eno e Michio Kurihara.

Esse modo de espacialização que chamamos vídeo-espaço se funda, portanto, na reconfiguração da lógica do quadro afastando-se de uma tentativa de representação do espaço pelo viés da perspectiva e narrativa linear, apresentando um caminho que se difere da causalidade por meio da sequencialidade, e constituindo-se essencialmente pelo viés da simultaneidade e continuidade. Aqui nos atemos a apresentar alguns exemplos de como essa relação aparece em propostas mono-canal, no entanto, ao avançarmos no estudo dos modos de espacialização, perceberemos com esses procedimentos podem ser coexistentes a propostas de espacialização do vídeo para o espaço físico. 


\title{
3.1.2. SEGUNDO MODO: APARELHO-ESPAÇO
}

Esse modo se refere especificamente a trabalhos que são exibidos em monitores de pequenas dimensões. Esses monitores deixam de ser apenas um meio tecnológico pelo qual o vídeo é exibido, neutro, para tomar as dimensões de objeto poético. $\mathrm{O}$ artista se apropria do aparelho, portanto, para conferir a ele o status de "objeto" de arte. Existe aqui uma outra relação com esse objeto chamado monitor, que percebemos estar muito relacionada a uma questão de acúmulo, a junção de monitores, que se diferencia das videowalls em grandes dimensões, por se apresentar como um objeto em si ou conjunto de objetos que, na referência com aquela constante corpo, está em escala menor. O processo de espacialização acontece, portanto em uma espécie de externalização da imagem videográfica bidimensional para o âmbito do objeto tridimensional instalado em dado espaço, o monitor como um invólucro que estabelece significados para a narrativa videográfica. Nesse trabalho, os espectadores não mais se restringem à tela luminosa, podem rodear o monitor ou conjunto de monitores levantando uma experiência que está atrelada ao que Chris Meigh Andrews (2014) aponta como o que ficou conhecido por vídeo-escultura. Sobre isso, o autor declara:

\begin{abstract}
Video escultura, apesar de um subproduto do video multi-canal, é menos cinematográfica e mais escultural. Não se espera que os visitantes da galeria sentemse e assistam a vídeo escultura de um ponto de vista único - eles são encorajados a caminhar ao redor, a assistir de todos os lados e ângulos, como se fosse uma escultura tradicional (...). As imagens e sons, apesar de importantes, são apenas elementos a serem lidos em relação com a estrutura e formas que são simultaneamente o suporte técnico das imagens/sons e um elemento integral do trabalho (MEIGH-ANDREWS, 2014, p. 303).
\end{abstract}

As imagens na tela são geralmente simples, repetitivas e gráficas, talvez até mesmo de importância secundária, simplesmente reforçando ou complementando a estrutura física - peixes nadando em um aquário, uma imagem estática de flores, imagens de televisões fora do ar eletronicamente processadas, etc. (MEIGH-ANDREWS, 2014, p. 303).

Uma das versões do trabalho O senhor é meu Pastor e nada me faltará (2012) de Victor De La rocque ${ }^{11}$ exemplifica essa dialética entre aparelho e espaço. O trabalho de De La Rocque, de maneira geral, se caracteriza pela problematização da natureza animalesca híbrida que funda a condição humana. O artista em várias obras utiliza a metáfora da condição de certos

11 "Nascido em Belém, é mestrando em Artes na Universidade de Brasília (UnB), bacharel e licenciado em Artes Visuais e Tecnologia da Imagem pela Universidade da Amazônia (UNAMA) e técnico em ator pela Universidade Federal do Pará (UFPA). Participou de exposições e residências artísticas no Brasil e no exterior em países como Portugal, França, Escócia, Suécia, México, Estados Unidos e Colômbia. Ganhador do Grande Prêmio do Salão Arte Pará 2008." Fonte: www.victordelarocque.com. 
animais que são criados pelos seres humanos para atender demandas que se referem a alimentação e vestimenta, por exemplo, como bovinos e galináceos. O trabalho citado acima é constituído por quatro televisões de tubo instaladas em cima da grama do jardim central de um museu. O mesmo vídeo é exibido nesses quatro aparelhos de televisão, no qual o artista metaforiza a partir de uma performance para a câmera a condição de um bovino se alimentando no pasto.

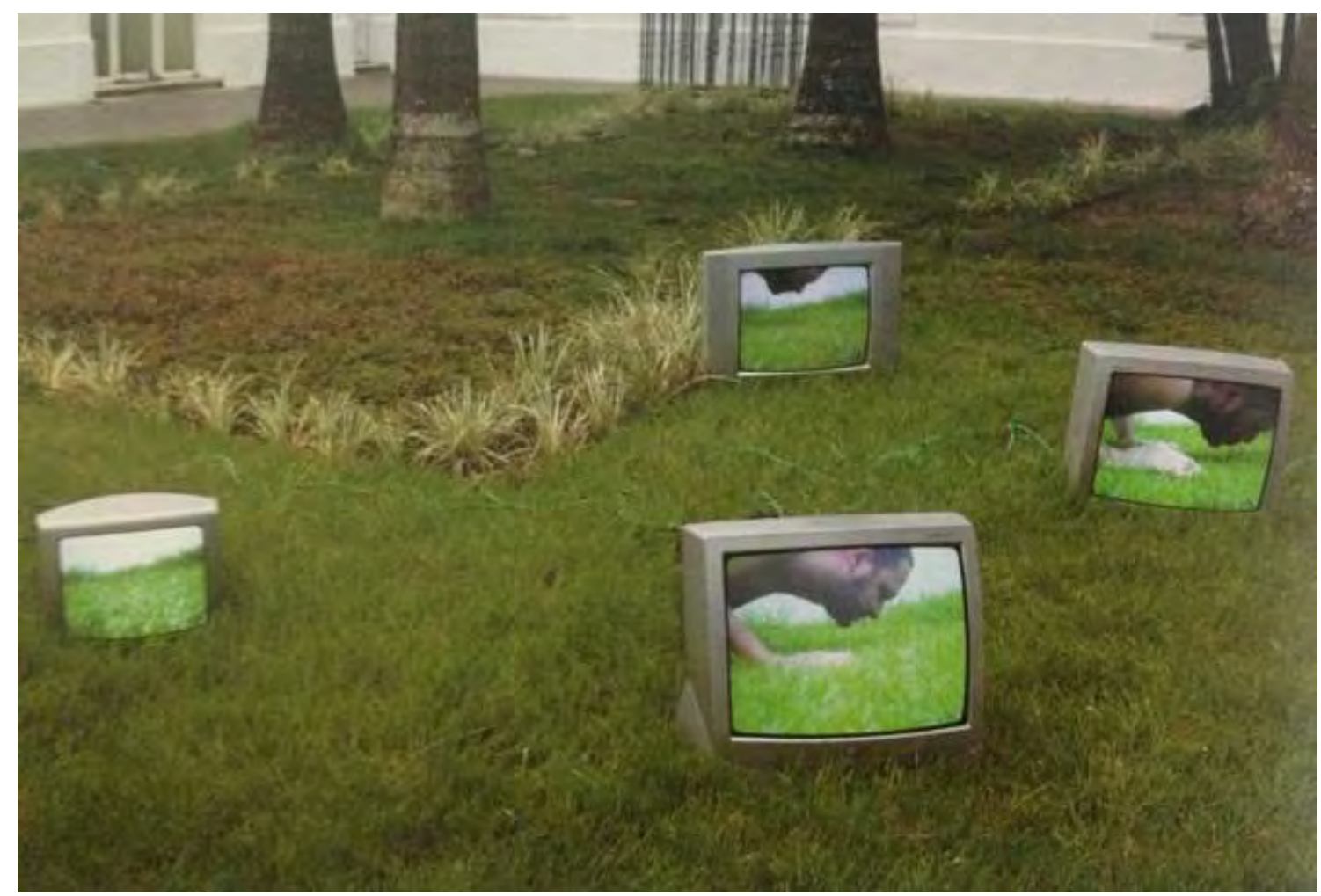

Ilustração 24: Registro da obra o Senhor é meu pastor e nada me faltará (2012) de Victor De La Rocque, instalada no jardim do Museu Histórico do Estado do Pará em Belém - PA.

Fonte: Acervo do projeto de pesquisa "Acervo de Videoarte paraense: sistematização e análise crítica" (CNPq/SEC/MinC - 2014-2016).

Foto: Victor D e La Rocque

O interessante aqui é perceber como o aparelho é o meio que fará a ligação entre dois elementos, a imagem bidimensional do vídeo e o espaço físico do museu. No vídeo vemos apenas um plano de perfil da cabeça do artista realizando essa ação de alimentação, que se desloca o tempo inteiro para fora do quadro e volta cada vez mais em plano detalhe até chegar a um estado de apresentação em que conseguimos visualizar de perto a ruminação desse pasto na boca do artista. A espacialização aqui já não reside mais apenas na sugestão imaginativa do que pode existir para além da base dessa imagem, onde se encontra enquadrado o pasto, como 
nos trabalhos de Luciana Magno e Gisele Beiguleman mencionados anteriormente, mas na tentativa de apresentar fisicamente, no espaço em que o monitor está instalado, esse âmbito do fora de campo, que reside na continuidade entre essa imagem virtual do pasto e o gramado do jardim, como se o artista por meio do vídeo se alimentasse daquele próprio espaço do museu, materializado pela grama. Portanto, a problematização do espaço sai apenas do quadro para tomar conta desse espaço concreto em que o corpo do espectador reside. O quadro vídeográfico é dotado nesse trabalho daquele aspecto de narrativas mínimas citadas por Meigh-Andrews anteriormente.

Em outro aspecto dessa espacialização, Nam June Paik em seu Bakelit Robot (2002) apresenta um agregado de objetos compondo uma unidade que caracteriza ainda mais essa abordagem escultórica. Nesse trabalho, uma espécie de desdobramento da Family of Robot: Mother and Father produzida na década de 1980, o artista constrói uma escultura em formato de robô formada por nove Bakelite radios. Esses Bakelite radios foram rádios comercializados principalmente no início do século XX e eram produzidos a partir de um plástico, o bakelite, utilizado na época para a construção desses aparelhos por apresentar características como leveza e resistência ao calor e atritos. Paik se apropria desses pequenos rádios para construir essa figura (formada por braços, pernas, tronco e cabeça) com uma clara estética vintage I2 $^{12}$ que remonta à relação doméstica de utilização desses aparelhos que foi tão forte quando da época de surgimento da televisão e, portanto, também ao próprio novo comportamento que surge nesse momento de inserção desses aparelhos nos ambientes residenciais.

Para a construção da obra, Paik retira os auto-falantes desses nove rádios, deixando um buraco nesses objetos, que são preenchidos por nove pequenos monitores. Nesses o que vemos é a apropriação de pequenos vídeos de desenhos animados que mostram robôs em narrativas de ficção científica, robôs esses que também foram fabricados como brinquedos utilizando aquele mesmo plástico bakelite. A estruturação do robô segue uma lógica em que cada vídeo corresponde centro de atenção que está relacionado aos seus membros, e deixa implícito a existência dos vídeos nessas posições como metáfora da possibilidade de um movimento do robô, que é estático enquanto objeto. Aquelas questões de simultaneidade que discutimos no tópico anterior existem agora não no jogo das imagens na tela, mas na constituição do objeto que é apreendido na sua unidade enquanto robô e nos fragmentos de vídeo que o compõem. Os monitores aqui são, por um lado, escondidos no interior dessas caixas plásticas dos bakelite radios, mas também incorporam sua materialidade pela narrativa apresentada.

12 Termo que se refere a recuperação de estilos de décadas passadas, principalmente as décadas de 1920 a 1960 , muito utilizado no território da moda. 


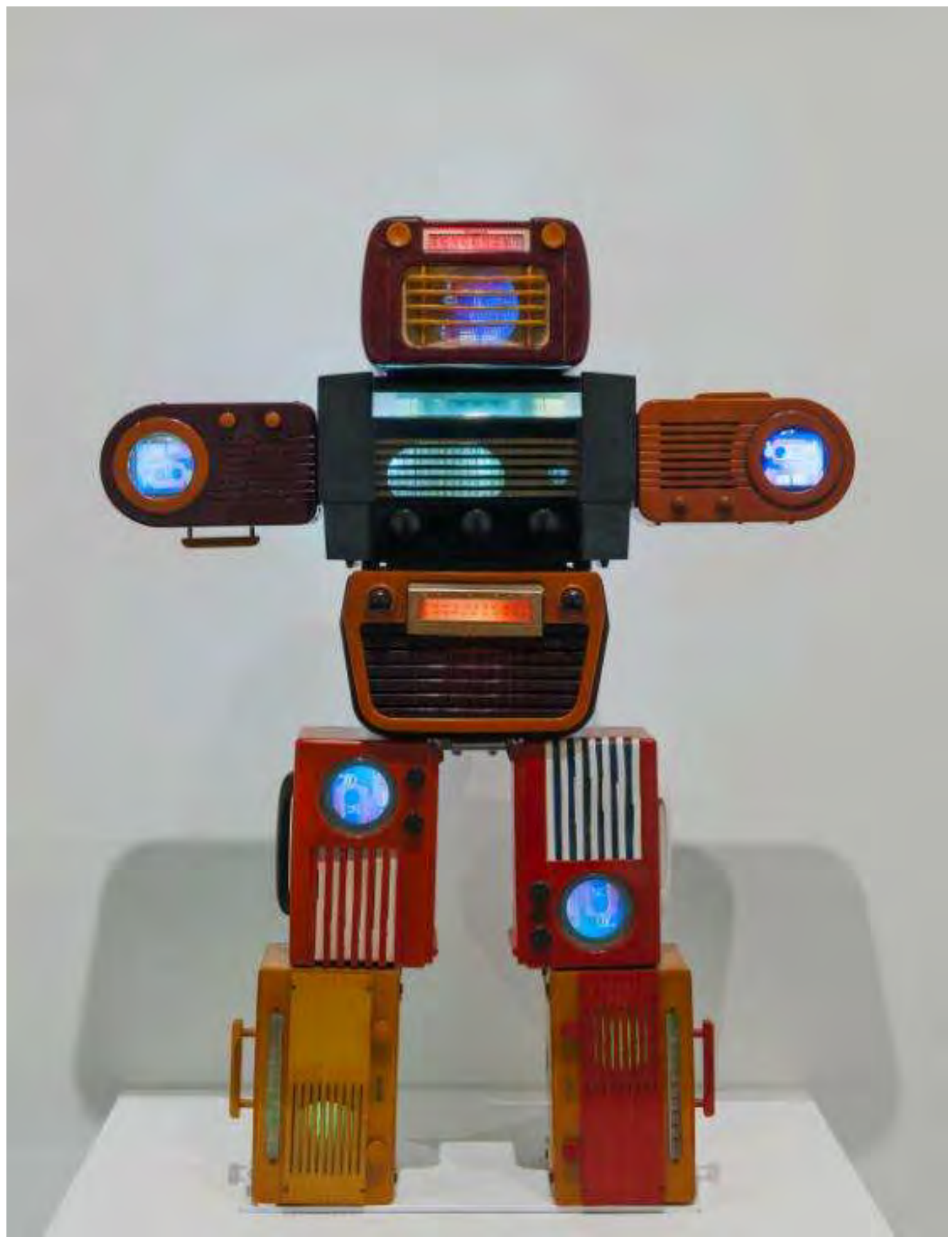

Ilustração 25: Registro da obra Bakelit Robot (2002) de Nam June Paik em exposição individual na Tate Modern, Londres em 2015.

Fonte: www.tate.org.uk

Foto: Licenciada por Nam June Paik state. 
Essa é a discussão principal desse modo que chamamos aparelho-espaço: a transmutação do monitor de mero aparelho de transmissão da imagem videográfica para objeto artístico, seja pela discussão de continuidade do espaço instalado, como no trabalho de Victor De La Rocque, seja pela sua modificação física por meio da inclusão de outros elementos, como no Bakelite Robot de Nam June Paik, ou mesmo na obra Nixon, citada no segundo capítulo deste trabalho.

\subsubsection{TERCEIRO MODO: VÍDEO-DISTENSÃO}

Este modo de espacialização se refere à prática de inclusão de objetos diversos próximos ao espaço em que o vídeo está instalado. Quando falamos em distensão estamos nos referindo, portanto, a trabalhos em que identificamos um certo efeito de ruptura com o monitor como único elemento pelo qual o vídeo exibirá sua narrativa. As características dessa narrativa passam a residir nessas obras na relação entre a imagem bidimensional do vídeo e as extensões dessa que são colocadas a certa distância do monitor, ao lado ou ao redor, e que podem se materializar por meio de objetos, fotografias, pinturas, desenhos, pequenas esculturas, mantendo ainda aquela característica das pequenas ou médias dimensões em que o corpo do espectador é quem ainda as envolve. A partir daqui é importante elencar que quando falamos de extensão nos referimos a esses objetos instalados, enquanto a distensão se refere ao processo mais abrangente que corresponde a saída do significado de um trabalho da tela do monitor para o encontro com essas extensões. Extensão como materialidade física, distensão como modo de espacialização. Nesse momento visualizamos ainda duas abordagens, por um lado, trabalhos que se atém à parede da galeria como suporte para instalação tanto do monitor quanto dessas extensões e, por outro lado, trabalhos que se apresentam muito mais na perspectiva escultórica apontada no tópico anterior.

Um exemplo dessa primeira abordagem é a obra O JOGO ou para que servem os amigos? (2006) de Valzeli Sampaio ${ }^{13}$. Esse trabalho é o primeiro experimento da série Sobre o tempo e outros deuses, em que a artista discute a natureza do tempo em suas dimensões de

13 "Artista visual, produtora e curadora independente. Tem experiência na área de produção, pesquisa em poéticas e crítica em Artes, com ênfase em arte contemporânea, design e novas mídias. Doutora e mestre em Comunicação e Semiótica (PUC/SP) e Pós-doutorado em Poéticas Digitais (ECA/USP). Atuamente é professora adjunta da Universidade Federal do Pará, na Faculdade de Artes Visuais do Instituto de Ciências da Arte (ICA/UFPA). Professora do Mestrado em artes do ICA. Mmembro do Conselho Acadêmico da Revista Eletrônica Art\& e da Revista Concinnitas." Fonte: Curriculo lattes da artista, disponível em: http://lattes.cnpq.br/6142863342585522. 
construção de afetividades a partir do trabalho com a hibridização de linguagens, na fotografia e vídeo principalmente. Nessa obra especificamente Sampaio apresenta três pequenas fotografias (com dimensões de 12,42 x 10,16 cm) impressas em material transparente e aplicadas sobre placas de vidro e um pequeno monitor que exibe um vídeo de celular em loop, os quais foram dispostos lado a lado horizontalmente na parede da galeria. Considerando a leitura ocidental comum da direita para a esquerda, em função da disposição linear desses elementos na parede, percebemos um percurso que apresenta uma decomposição da imagem do vídeo.

A primeira e a última fotografia são imagens de celular de uma figura feminina que se embala sobre um balanço em um ambiente com plantas ao fundo, e são intercaladas pela fotografia da sombra de uma planta projetada em uma parede por efeitos de luz. O vídeo, gravado também em celular, exibe imagens dessa mesma mulher se embalando, uma espécie de versão em movimento das fotografias citadas. Uma questão importante a ser levantada é a da definição da imagem desse vídeo, que por ter sido gravada em celular é baixa e apresenta uma pixelização, principalmente em função do movimento que é realizado na ação. Essa pixelização, que expõe a própria natureza da formação da imagem do vídeo digital, parece ser apropriada pela artista e subvertida para um âmbito poético, assim como os primeiros videoartistas fizeram no território do vídeo analógico. Os pequenos quadrados de pixel que surgem e se movimentam junto com o balanço de certa maneira modificam a própria espacialidade do quadro por meio da deformação das figuras que os constituem, é como se essa natureza do vídeo se expusesse para acompanhar esse movimento de modificação. Esse movimento de se balançar, o pêndulo, uma invenção humana que transforma a experiência do tempo na ordem da medição matemática, reverbera nessa construção de espacialidade.

No vídeo ouvimos a personagem feminina ensinar para amigos algumas técnicas para um movimento eficaz no balanço. Aos cinco segundos a imagem é congelada no momento em que a personagem se encontra parcialmente fora do quadro e interrompe o movimento do balanço em direção ao centro, mas o áudio com as instruções continua sendo executado. Aqui reside para nós justamente o gancho narrativo para a edificação das extensões materializadas nas fotografias, na medida em que estas parecem dar continuidade ao congelamento do vídeo por meio de imagens fixas. Essa distensão narrativa pela fotografia é também, como já citado, interrompida por aquela imagem da sombra da planta projetada diagonalmente, no que parece ser uma comparação ao próprio movimento do balanço. $\mathrm{O}$ jogo reside nesse entremeio entre o movimento e a interrupção que funda esse processo de espacialização. 

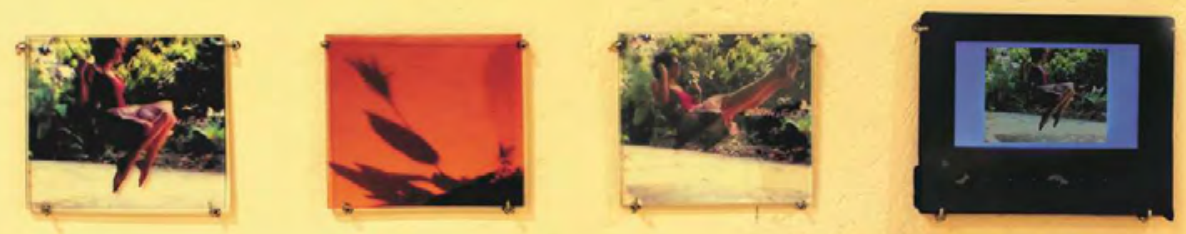

Ilustração 26: Registro da obra O JOGO ou para que servem os amigos? (2006) de Valzeli Sampaio no Laboratório das Artes da Casa Onze Janelas durante a exposição “Amazônia, lugar de experiência” em Belém do Pará (2014).

Fonte: Acervo do projeto de pesquisa “Acervo de Videoarte paraense: sistematização e análise crítica” (CNPq/SEC/MinC - 2014-2016).

Foto: Orlando Maneschy

Essas discussões temporais são também levantadas em Ahora (2007) de Melissa Barbery $^{14}$, apresentado em uma parede e constituindo-se por uma pequena tela que exibe um vídeo colocada ao lado de uma muda de planta. O vídeo inicia com a imagem de um vaso de planta no centro do quadro com sua sombra projetada na parede pelo encontro com uma luz artificial. Essa sombra vai durante alguns segundos mudando de posição, da direita para a esquerda da tela, enquanto ouvimos uma voz feminina, a avó da artista afetada pelo Alzheimer discursar a respeito do tempo, comparando seu estado atual a uma calmaria e incompreensão do mundo encontrada nas suas memórias de infância, como lembranças em câmera lenta, finalizando concomitantemente ao momento em que a sombra da planta chega ao outro extremo da imagem.

Em seguida os braços de Barbery entram em quadro e a artista inicia um processo lento de retirada de todas as folhas daquela planta para colocá-las no adubo contido no vaso. $\mathrm{O}$ crescimento da planta é interrompido por essa retirada para uma espécie de retorno a um espaço

14 "Mestre em Artes pela Universidade Federal do Pará e bacharel em Artes Visuais e Tecnologia da Imagem pela Universidade da Amazônia. Atualmente é professor do Instituto de Estudos Superiores da Amazônia e Técnica em Gestão Cultural na Fundação Curro velho. Tem experiência na área de Artes, Design e Multimídia.' Fonte: Currículo Lattes da artista, disponível em: http://lattes.cnpq.br/4489646173291893 
onde as raízes se encontram, um retorno dessa experiência de crescimento ao seu estado primário e que se relaciona diretamente ao discurso proferido por sua avó, uma tentativa de recuperação e deslocamento da memória como uma categoria temporal. No vídeo a artista utiliza-se ainda dos processos de sobreimpressão durante a retirada das folhas, em que vemos seus braços, sobrepostos, existirem de maneira fantasmagórica e sutil, em uma espécie de compressão do tempo real da retirada em um tempo sobreposto do vídeo.

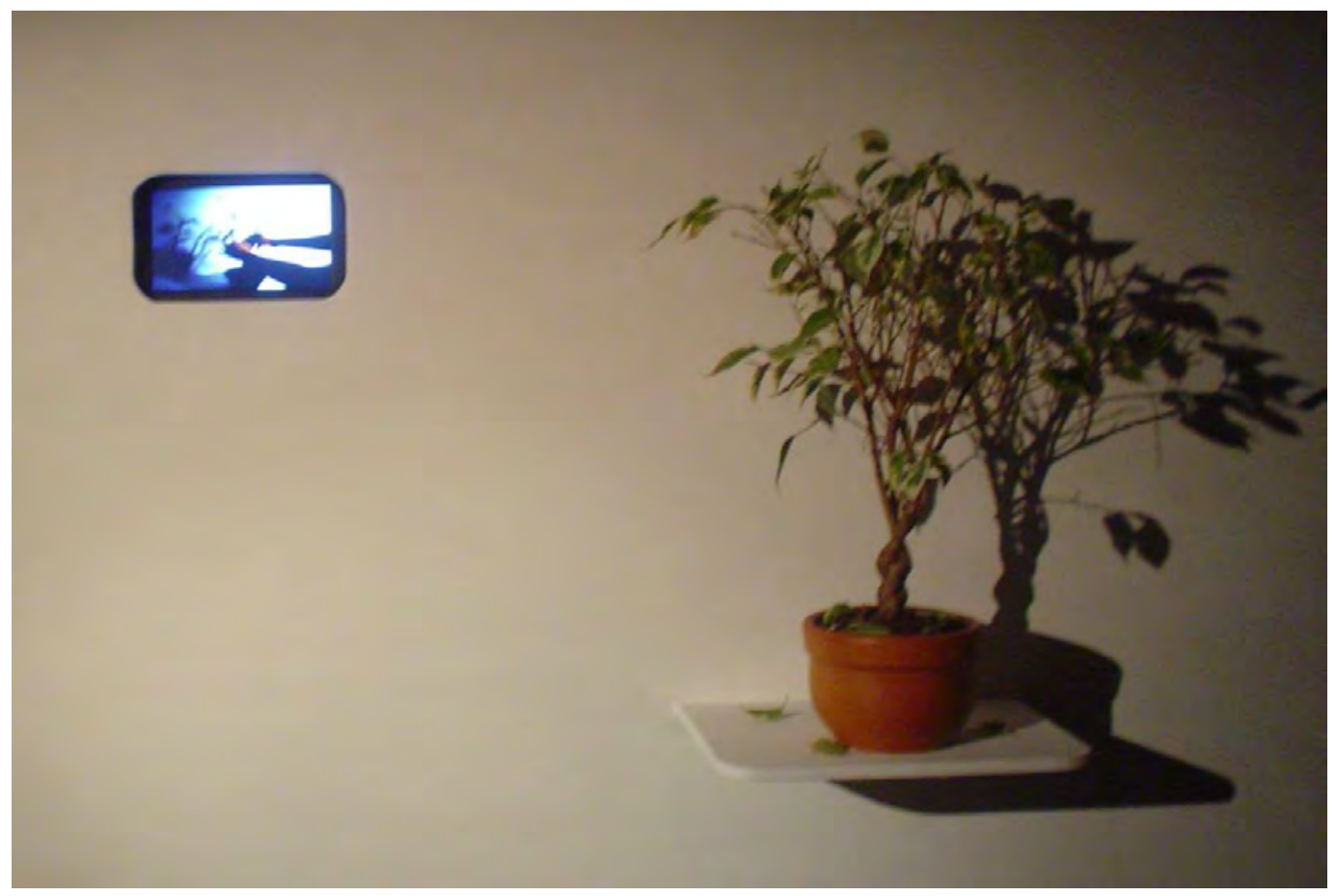

Ilustração 27: Registro da obra Ahora (2007) de Melissa Barbery exibida no Museu Histórico do Estado do Pará (Belém-PA) durante o $26^{\circ}$ Salão Arte Pará em 2007.

Fonte: Acervo do projeto de pesquisa "Acervo de Videoarte paraense: sistematização e análise crítica" (CNPq/SEC/MinC - 2014-2016).

Foto: Melissa Barbery

O processo de espacialização como distensão se dá pela duplicação do assunto do vídeo naquele vaso de planta, e, portanto, se difere da prática de Valzeli Sampaio por incluir um objeto tridimensional. Essa planta colocada ao lado do vídeo durante a exposição, geralmente entre um e dois meses, não é regada e nem recebe luz solar, o que leva à sua morte ao longo desse período, incluindo a queda de suas folhas no espaço expositivo, assim como no vídeo. A planta como extensão é, portanto, uma versão tridimensional da abordagem de tempo presente no vídeo a partir de um tempo real da natureza de sua morte, uma metáfora da morte como constituída essencialmente pela experiência do tempo. 

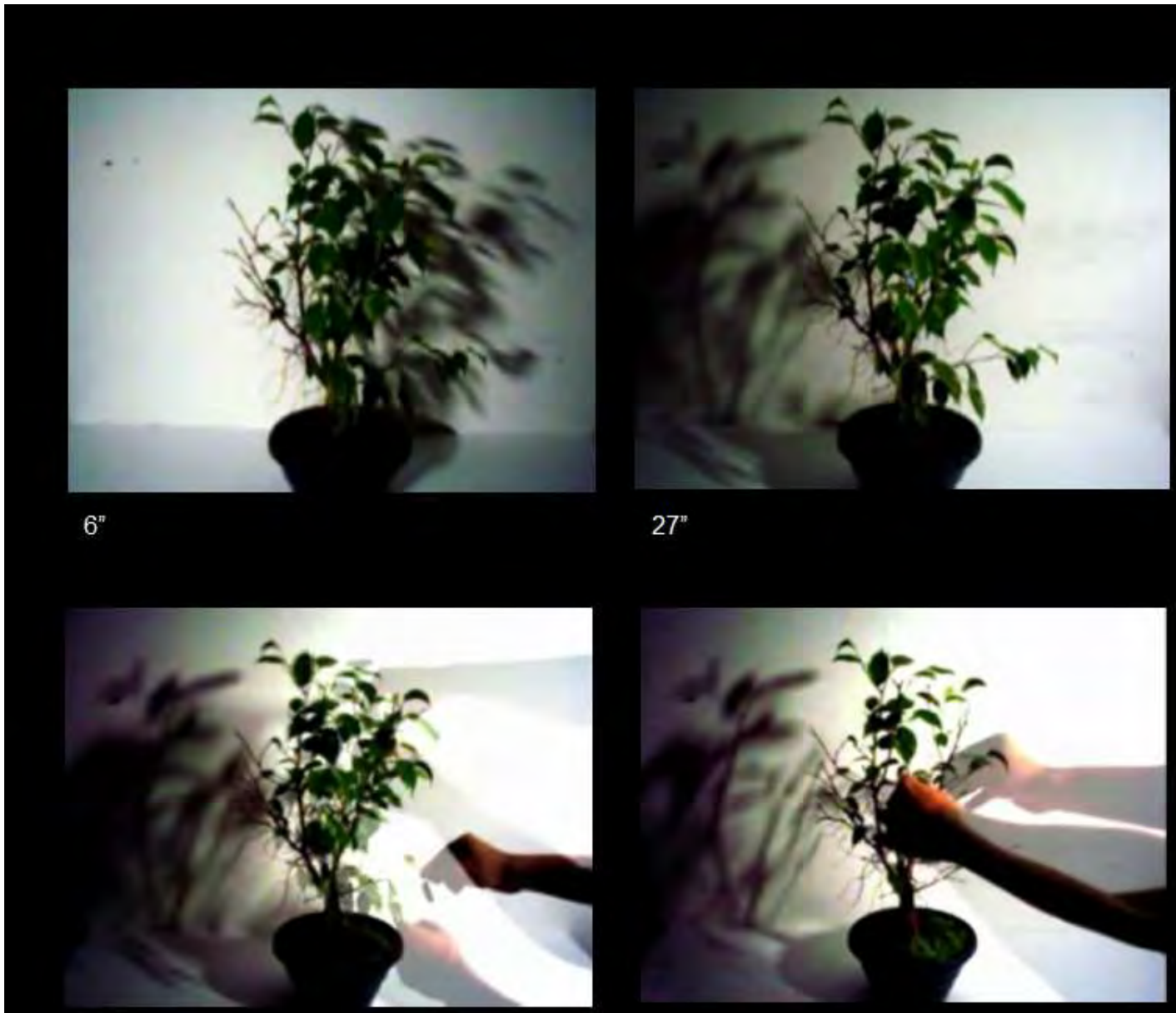

$2^{\prime 2} 23^{\prime \prime}$
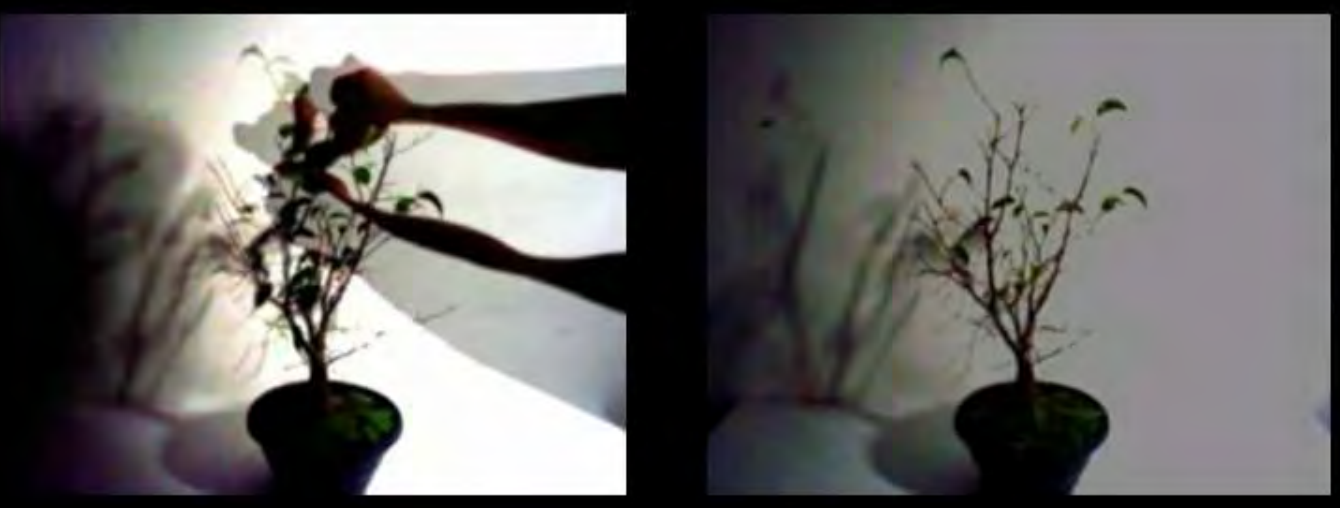

Ilustração 28: Frames do vídeo que compõe a obra Ahora (2007) de Melissa Barbery.

Fonte: Acervo do projeto de pesquisa "Acervo de Videoarte paraense: sistematização e análise crítica" (CNPq/SEC/MinC - 2014-2016). 
Uma segunda abordagem, mais escultural, pode ser pensada a partir de Victrola (2005) de Nam June Paik, que se constitui formalmente por uma tela de plasma fixada na parede, um móvel de madeira integrado por uma vitrola, posicionado embaixo da tela e a uma certa distância da parede, e um disco de vinil quebrado colocado a frente desse móvel. Detalhemos os dois primeiros elementos. A tela de plasma, de cerca de 20 polegadas, exibe o vídeo Fluxus Sonata (1974), registro de uma performance em que Paik quebra um disco de vinil. O móvel, de dimensões maiores que a tela de plasma, encontra-se com as portas abertas, onde vemos uma tela de pintura e alguns vinis. A superfície desse móvel é também tomada por uma série de pinturas que lembram desenhos de criança e ao mesmo tempo pixações, compostas por cores como o amarelo, o vermelho, branco e azul.

Essas pinturas conferem ao móvel um certo ar de antiguidade, de abandono e deixam implícito o não funcionamento da vitrola que tem relação direta com as discussões desse trabalho. O conjunto de elementos da obra dá continuidade às apropriações que Nam June Paik faz de algumas mídias já substituídas, ultrapassadas (como no Bakelite Robot apresentado nesse capítulo), conferindo a elas outros significados para pensar a relação humana com a velocidade do desaparecimento dessas mídias, que embute nesses objetos tecnológicos a lógica do abandono que o estado do móvel apresenta.

A espacialização nesse trabalho inclui o processo da saída parcial da parede. Enquanto os trabalhos de Valzeli Sampaio e Melissa Barbery são posicionados a uma certa altura dos olhos do público, o trabalho de Paik incorpora uma distensão entre esses elementos que solicita um movimento de visualização da tela na altura dos olhos, passando por um espaço intermediário contínuo em que móvel se encontra, até o chão em que o vinil quebrado está instalado. A proposta do trabalho só pode ser visualizada, portanto, nesse movimento de conexão entre esses três níveis espaciais em um aspecto de retomada um do outro. Esse vinil quebrado disposto no chão retoma a sua ausência fragmentada e frágil enquanto mídia naquela vitrola, que por sua vez retoma o vídeo que exibe a quebra de um outro vinil. Paik parece apresentar aqui processo e materialização da obsolescência dessa mídia como índice de um contexto midático mais geral por meio dessas distensões entre vídeo e objetos.

Em outro sentido, a parede é completamente abdicada em Pandora The Electronic Box (1993 e 1995) de Mariano Klautau Filho ${ }^{15}$, apresentada em duas versões. Quando da

15 "Doutor em Artes Visuais pela Escola de Comunicações e Artes da Universidade de São Paulo - ECA/USP (2015). Mestre em Comunicação e Semiótica pela Pontifícia Universidade Católica de São Paulo (1999). Professor da Universidade da Amazônia desde 2000. Participa de exposições no Brasil e exterior. Fonte: Currículo lattes do artista, disponível em: http://lattes.cnpq.br/8786771910755876. 


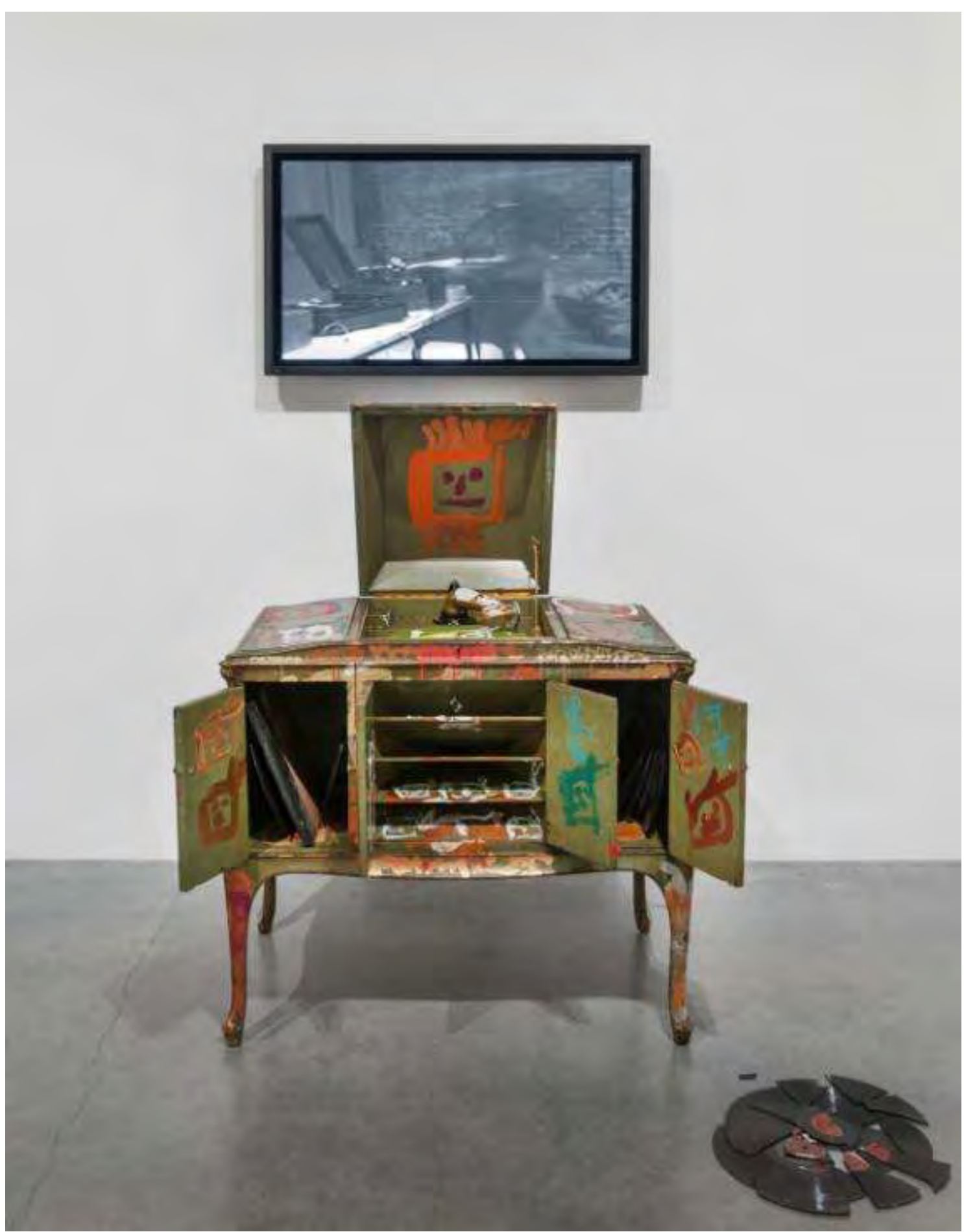

Ilustração 29: Registro da obra Victrola (2005) de Nam June Paik em exposição individual na Tate Modern, Londres em 2015.

Fonte: www.tate.org.uk

Foto: Licenciada por Nam June Paik state 
apresentação desse trabalho Klautau Filho era integrante do grupo Caixa de Pandora ${ }^{16}$, um coletivo de artistas que criaram exposições dialogando com as questões de perda, memória, esquecimento, surpresa que o mito de Pandora ${ }^{17}$ levanta. Em ambas as versões o artista materializa essa figura mítica da Pandora como o próprio aparelho de televisão, a caixa tecnológica pela qual segredos, imagens, sensações, medos, esperanças são produzidos e exibidos, e cujo surgimento implicou em mudanças significativas no processo comunicativo, relações interpessoais e de reconfiguração do ambiente doméstico de intimidade na história da humanidade.

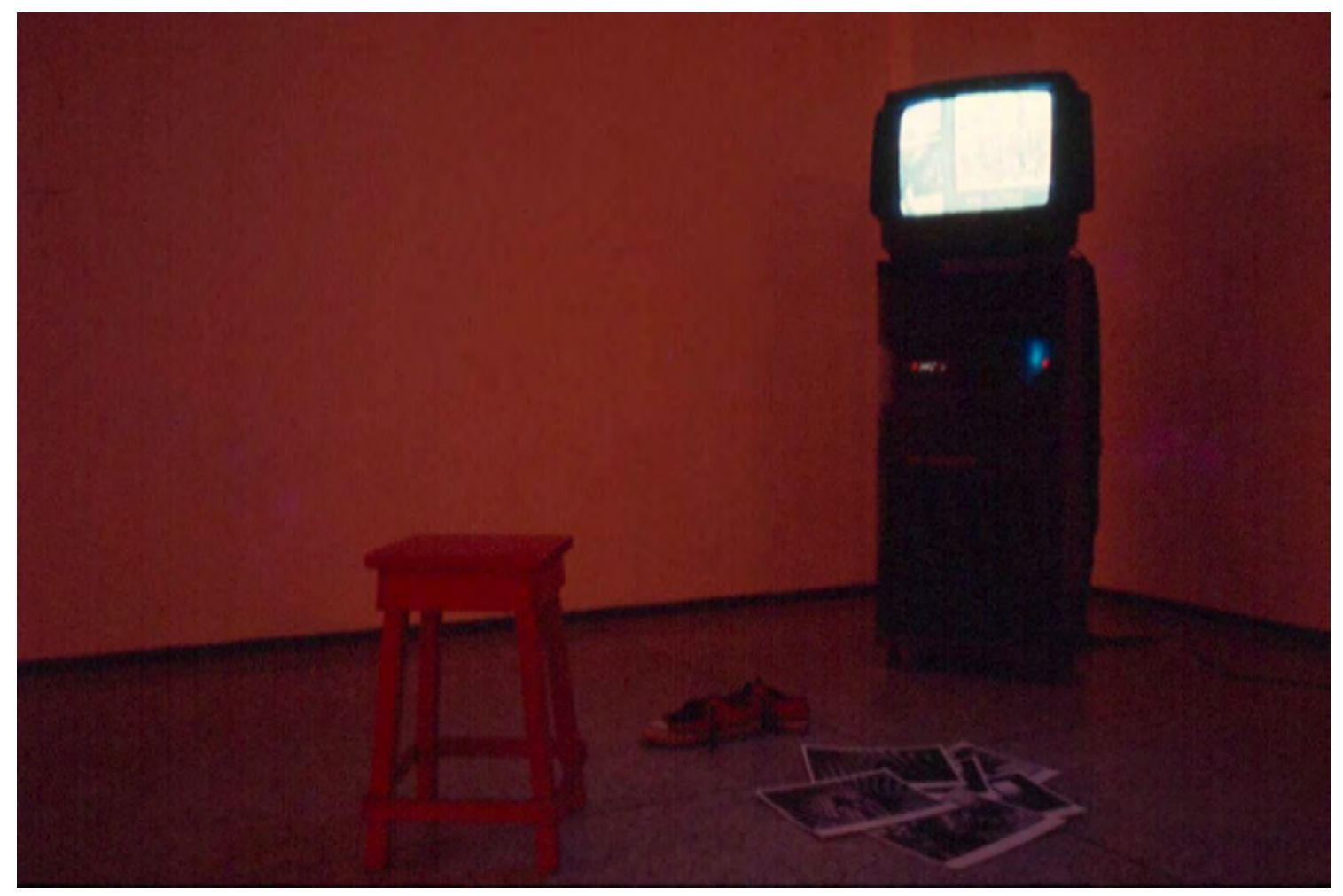

Ilustração 30: Registro da versão de 1993 da obra Pandora The eletronic box de Mariano Klautau Filho, exibida na Galeria Theodoro Braga em Belém do Pará no mesmo ano.

Fonte: Acervo do projeto de pesquisa "Acervo de Videoarte paraense: sistematização e análise crítica" (CNPq/SEC/MinC - 2014-2016).

Foto: Mariano Klautau Filho

16 Grupo de artistas paraenses formado por Cláudia Leão, Flavya Mutran, Mariano Klatau Filho e Orlando Maneschy. Na década de 1990 foram uns dos pioneiros na produção de obras instalativas no circuito de arte da amazônia brasileira.

17 Mito grego que se refere ao surgimento dos males físicos e espirituais do mundo após a abertura de uma caixa, que continha esses elementos, por Pandora, que ao perceber o que havia feito fechou rapidamente essa caixa conseguindo manter ainda o único bom elemento depositado no recipiente, a esperança. 
A primeira versão do trabalho, datada de 1993, é situada no canto de uma galeria e composta por um aparelho de televisão sobre um móvel, um controle remoto, uma cadeira, um par de tênis e algumas fotografias dispostas no chão, todos próximos uns dos outros. O vídeo, homônimo ao título do trabalho, e sem som, trata-se de uma colagem de imagens fixas feitas por processo de edição eletrônica que, segundo o autor, remetem a uma plasticidade da montagem no cinema e as imagens das histórias em quadrinhos, linguagem inclusive citada por Lev Manovich (2001) como exemplo da montagem espacial na literatura. Essas imagens mostram primeiramente uma personagem feminina que se alterna entre uma reflexividade no espaço vazio em que se encontra e a relação com a cidade nos prédios que compõem a paisagem de sua varanda, seguida por uma outra mulher, uma espécie de alter-ego, que duela com um personagem masculino dentro de uma piscina vazia. No final do vídeo vemos imagens de transeuntes em uma cidade, configurando uma espécie de duelo interno dessa personagem entre a categoria da presença no público e no privado

Dispostas no chão da galeria, as fotografias apresentadas tratam-se das próprias imagens que serviram de matéria-prima para a produção do vídeo, uma decomposição do movimento em imagens fixas muito parecida com aquela apontada no trabalho de Valzeli Sampaio, permitindo um arranjo diferenciado dessas fotografias que é executado pelo público (primeiro processo de distensão). Ao mesmo tempo, ao posicionar uma cadeira e um par de tênis no espaço o artista convida o público a simular a comodidade do ambiente doméstico que essa caixa de pandora televisiva problematiza metalinguisticamente, acompanhado pelo controle remoto que permite ao público efetuar ações de avanço, pausa e retorno sobre o vídeo, simulando pelo videotape aquelas escolhas que acontecem na televisão conhecidas como zapping, o hábito de mudança de canal na entrada de comerciais na programação (segundo processo de distensão). A espacialização aqui ocorre de modo muito mais randômico do que nos trabalhos anteriormente citados neste tópico.

Na segunda versão do trabalho o vídeo é agora intercalado pelo poema O Homem e sua Hora de Mário Faustino, que fala essencialmente da passagem do tempo atravessada por questões de memória, sexualidade, transformações psíquicas e materiais. $\mathrm{O}$ vídeo constitui-se também por uma transição de planos formada pela aparição de um quadro negro que se move horizontalmente na tela, sobrepondo uma imagem para o aparecimento de outra. Além disso o artista suprime nessa versão os elementos cadeira e tênis e insere o monitor de televisão dentro de uma caixa de madeira que é posicionada no chão da galeria de modo ainda mais próximos das fotografias. Mariano Klautau Filho dota a obra de uma espacialidade que pode ser também construída pela ação do espectador ao lidar com escolhas no tempo de visualização do videotape 
e no arranjo das fotografias instaladas no chão. Ao disponibilizar essas imagens o artista lida até mesmo com a escala dessa distensão, já que ao internalizar esse estado de intimidade com a obra o público tem a possibilidade de deslocar esses elementos por todo o espaço da galeria, inclusive os distanciando dessa Pandora eletrônica metaforizada pelo monitor.

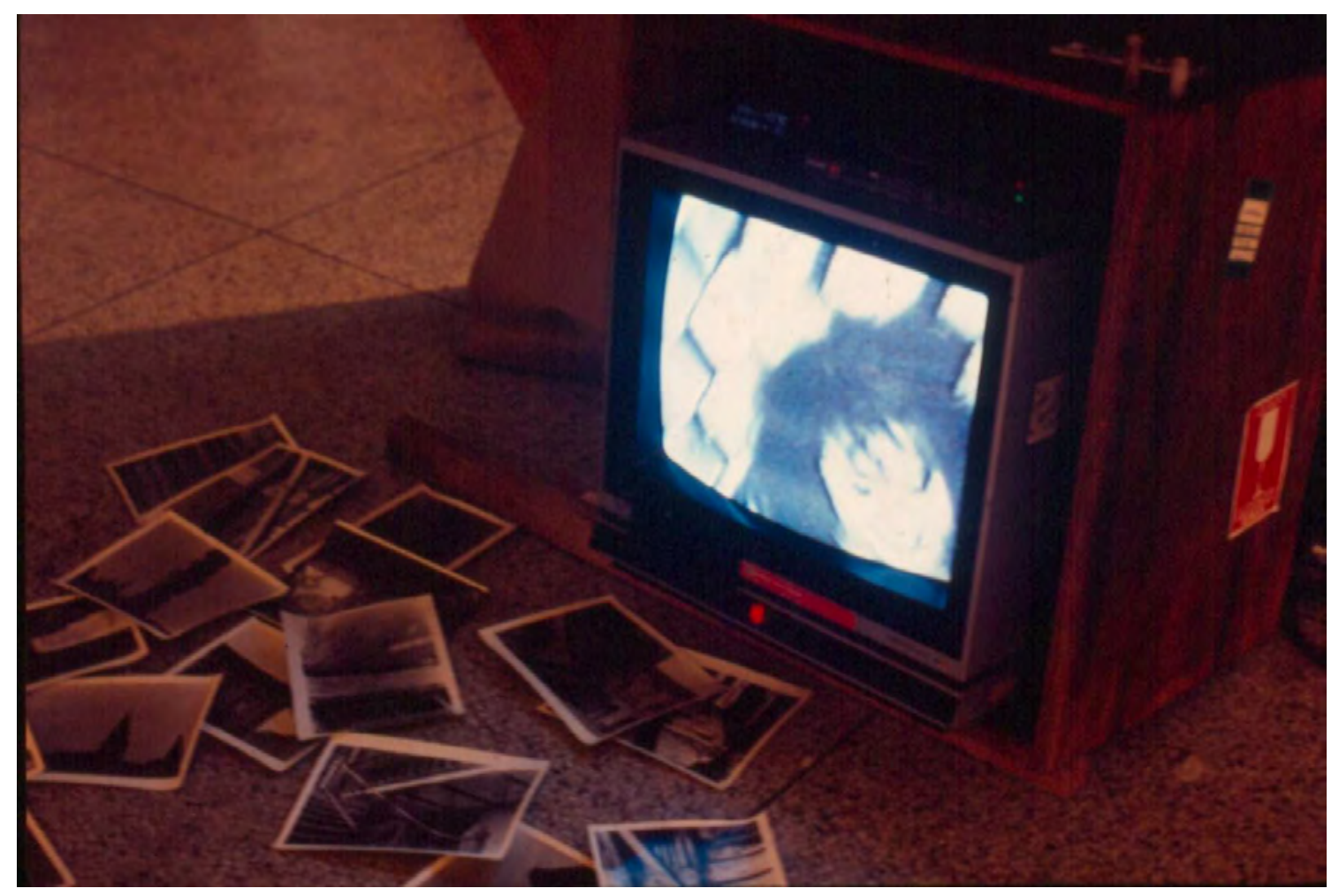

Ilustração 31: Registro da versão de 1995 da obra Pandora The electronic box de Mariano Klautau Filho, exibida na Galeria Theodoro Braga em Belém do Pará no mesmo ano.

Fonte: Acervo do projeto de pesquisa "Acervo de Videoarte paraense: sistematização e análise crítica" (CNPq/SEC/MinC - 2014-2016).

Foto: Mariano Klautau Filho

Com isso, a análise até aqui realizada nos faz perceber como esses modos de espacialização se acumulam em certos momentos em uma mesma obra a partir das extensões incluídas na relação com a imagem videográfica. O trabalho de Melissa Barbery, com a utilização das sobreimpressões no vídeo (vídeo-espaço) e a inclusão de outros objetos, bem como a discussão espacial no quadro, a personificação do monitor como elemento poético (aparelho-espaço), e a inclusão de extensões em objetos (vídeo-distensão) no trabalho de Mariano klautau filho são exemplares para demonstrar essa situação de cruzamento entre os modos de espacialização que compõem essa operação maior que chamamos microespacializações. 


\subsection{SEGUNDA OPERAÇÃO: MACRO-ESPACIALIZAÇÕES}

A segunda operação de espacialização se refere a propostas artísticas em que o dispositivo vídeo é apresentado em grandes dimensões e funda um ambiente que em movimento contrário à operação anterior domina fisicamente o corpo desse espectador que se encontra no espaço, aproximando-se daquela categoria instalação que Claire Bishop (2005) e Milton Sogabe (2008) problematizam. Nessa operação os trabalhos geralmente ocupam uma sala inteira do espaço expositivo por meio da exibição do vídeo em duas principais situações: a inclusão de uma série de monitores ou a projeção digital do vídeo direto na parede da galeria ou em suportes construídos para isso.

$\mathrm{Na}$ primeira situação essa série de monitores se relacionam com uma diversidade de objetos que se instalam ao longo do espaço físico e estabelecem aquele mesmo mecanismo de ruptura conceitual com o monitor como único meio de apreensão da narrativa do trabalho. A segunda situação também insere essa mesma perspectiva de inclusão de extensões tridimensionais da narrativa, com a diferença de que a imagem videográfica é exibida por meio da projeção. Nesse segundo momento, no entanto, identificamos também propostas em que apenas as projeções em grandes dimensões são apresentadas, seja por meio de uma ou várias telas, conferindo significado ao espaço vazio da galeria, como apontado por Sogabe, e retomando algumas características das tradicionais salas de exibição de cinema, mas certos aspectos que a diferenciam, principalmente no que se refere à experiência do espectador nesse espaço.

Os próximos três modos de espacialização incluem, portanto, esse dado novo da utilização de projeções digitais, em que o vídeo sai da caixa do monitor e se torna um elemento fluído que se adapta aos espaços físicos geralmente em grandes proporções e volta a solicitar o espaço escuro das salas para sua visualização em algumas situações. Liz Kotz (2009) aborda a questão da projeção, por um viés mais filosófico, da seguinte forma:

Projeção - do latim projectionem (de pro + jacere), que significa "jogar para frente, extensão, projeção" - indica distensão, deslocamento, transferência. Essencialmente projeção é uma forma de geometria modelada nas propriedades dos raios de luz: permite-nos desenvolver, de um ponto fixo, grande quantidade de correspondências regulares entre dois planos ou entre um plano de figura bidimensional e o espaço tridimensional. Como tal, a geometria projetiva é um meio de racionalizar a visão e o espaço, dando base para a tradução perspectiva, cartografia e arquitetura. (..) Inspirando-nos em décadas de teoria do cinema, podemos mapear como as técnicas de projeção oferecem modos de junção com um espaço, uma imagem e um objeto. (KOTZ, 2008, p. 50) 
Para a autora a projeção digital foi disseminada nos espaços de museus e galerias principalmente a partir da década de 1990, levantando algumas características e consequências dessa entrada. Primeiramente, os espectadores podem nessa situação de certo modo interromper o processo de projeção ao se posicionarem entre a tela que recebe os fluxos luminosos e o aparelho projetor, que segundo a autora não acrescenta novos significados reais ao trabalho. Em segundo lugar, a adaptação da própria arquitetura das salas de exibições como uma espécie de moldura, se esquivando de uma abordagem da utilização do vídeo no monitor como uma espécie de substituição da pintura. Por fim, um certo movimento de retorno à narrativa cinematográfica instituída por essa linguagem mais tradicional que se construiu ao longo dos anos entre uma estabilidade e um experimentalismo. Apesar das características elencadas por Kotz serem pertinentes e de fato existirem nessa relação com a projeção, a apresentação de alguns trabalhos que se seguem nesse tópico mostra como existem ainda outras possibilidades de atuação com a projeção, na relação com o espaço e com a narrativa em vídeo.

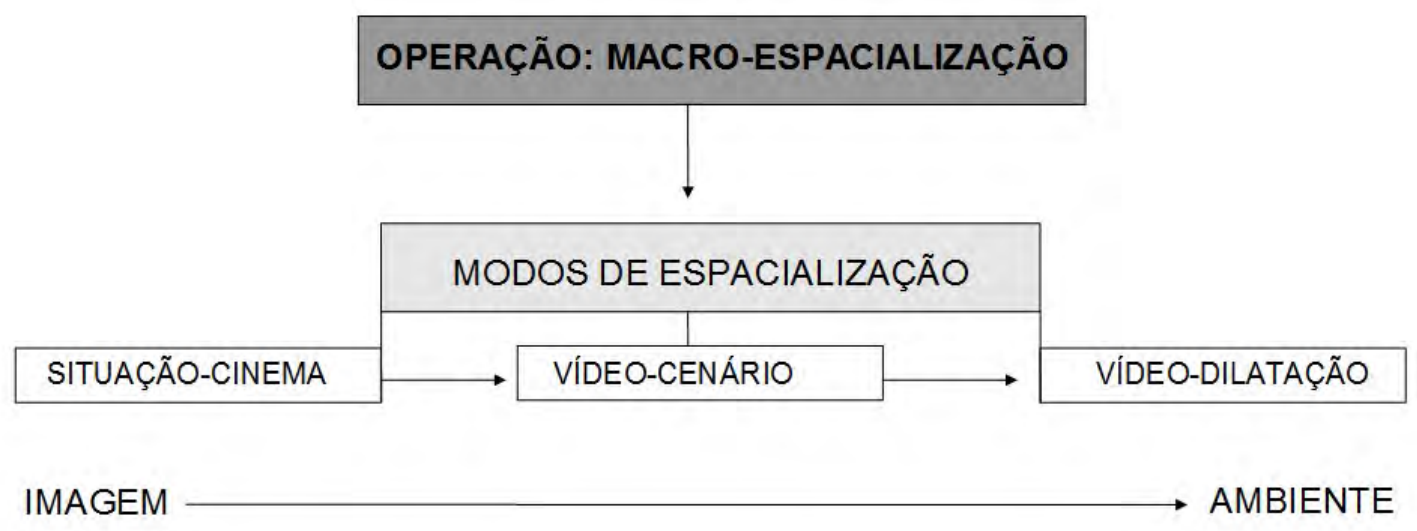

Figura 32: Diagrama da Macro-espacialização

Dessa maneira, essa operação de macro-espacialização é formada por três modos de espacialização, a saber: situação-cinema, vídeo-cenário e vídeo-dilatação, conforme apresentado no diagrama acima. Esses modos instituem um percurso de espacialização e criação de ambientes que vão da apresentação de grandes projeções em uma ou mais telas, a utilização de múltiplos monitores e extensões e configuram também outro importante processo, o de uma inclusão mais participativa, fisicamente falando, do espectador, seja no próprio espaço da galeria ou por ações externas que modificam de alguma maneira esses trabalhos. Outra situação que também se instaura é a presença do artista nesses espaços a partir da realização de performances, um corpo que possibilita a edificação de outras temporalidades na experiência 
com esses ambientes, construídos geralmente por uma ação que existe em um espaço-tempo delimitado por duração de apresentação.

\subsubsection{PRIMEIRO MODO: SITUAÇÃO-CINEMA}

Neste modo de espacialização identificamos a emergência das fricções entre a projeção digital da videoarte na galeria e uma forma cinema, denominada assim por André Parente (2006), em um caminho de diálogo ou ruptura com certos elementos que constituem essa última. O autor define essa forma cinema como:

(...) um espetáculo que envolve ao menos três elementos distintos: uma sala de cinema, a projeção de uma imagem em movimento e um filme que conta uma história em cerca de duas horas. (...) podemos afirmar que, em seu dispositivo, o cinema faz três dimensões convergirem: a arquitetura da sala, (...); a tecnologia de captação/projeção, cujo padrão foi inventado no fim do século XIX; e a forma narrativa (estética ou discurso da transparência) adotada pelos filmes no início do século XX, sobretudo o cinema de Hollywood sob a influência da vontade de viajar sem se deslocar (...). (PARENTE, 2006, p. 23-24)

Parente está nesse momento falando da forma cinema como esse hábito de sair de casa para entrar numa sala escura que se constituiu socialmente como um dispositivo em que o corpo deveria entrar, sentar, silenciar-se, ater sua atenção à grande tela e assistir a um filme do início ao fim, indicando uma espécie de fantasmagoria da imagem, a qual entramos e nos identificamos com o percurso de dados personagens. O autor aponta que o cinema enquanto dispositivo não surge necessariamente nessa formatação, que se constituirá como dominante até os dias de hoje, mas se apresentou com experiências diversificadas no cinema dos primeiros tempos (1896-1908), um cinema de atrações materializado, por exemplo, nos vaudevilles, citando ainda outras experiências de problematização desse formato, seja no território da arquitetura da sala ou da narrativa, como o cinema experimental e o cinema interativo.

Os trabalhos que apresentaremos aqui atuam, portanto, naquelas duas direções que apontamos anteriormente. Por um lado, um diálogo com duas características que são fundantes a essa forma cinema: a sala escura e a projeção de uma ou mais imagens em grandes dimensões. Por outro lado, estabelecem um estado de ruptura com a narrativa hollywoodiana clássica, apresentando um diálogo muito mais aproximado com aquelas relações que apontamos na prática do cinema abstrato e cinema estrutural, não necessariamente fazendo menção direta a esses movimentos. Essas duas características desembocam em outra situação, a atuação do público nesses espaços. Enquanto nessa forma cinema o público é convidado a sentar, na galeria 
esse público é passeante e tem a liberdade de deixar o espaço em que o vídeo é exibido no momento em que quiser sem nem mesmo assisti-lo por completo, mesmo em vídeos em que uma certa narratividade mais clássica se apresenta.

A experiência do público na galeria parece atuar no âmbito da dispersão, da escolha temporal de fruição de cada obra, e alguns trabalhos que retomam elementos da forma cinema como a longa duração podem, portanto, embutir na experiência um certo tédio que vai assolar esse espectador acostumado com outro tempo de percurso, fundando um abandono da visualização desses vídeos antes mesmo do término. Além disso esses trabalhos são fundados geralmente em um estado de loop e, portanto, essa narrativa acaba sendo visualizada de maneira fragmentada quando o espectador a encontra, assistindo o final do vídeo e depois retornando ao início, por exemplo. Falamos nesse momento de trabalhos em que uma certa linearidade narrativa, na maioria das vezes experimental, se apresenta, e que se difere daquelas propostas mais abstratas citadas anteriormente.

Em função dessa situação exposta, alguns artistas começaram a incluir objetos como cadeiras na galeria para imbuir esse espaço de uma certa intimidade com a imagem videográfica na tentativa de fazer com que o espectador se concentre na narrativa em sua totalidade. $\mathrm{O}$ que pode ser positivo nessa apreensão total, pode também ser o desvio de uma experiência experimental que o estado de dispersão da galeria permite. A utilização da palavra situação é, portanto, uma tentativa de conferir um outro significado ao termo utilizado por Parente, forma cinema, compreendendo essa situação como aquilo que Vilém Flusser designa como a "cena onde a cena onde são significativas as relações-entre-as-coisas e não as coisas em si" (FLUSSER, 2009, p. 79). Vejamos a partir de agora como essas relações aparecem em alguns trabalhos.

Na obra Cidades Vulneráveis (2008) Carla Evanovitch ${ }^{18}$ apresenta um vídeo projetado em uma parede inteira no fundo do espaço expositivo. A obra toma corpo a partir da ultrapassagem da parede que dá início ao ambiente de exibição do vídeo, onde logo na entrada encontramos uma placa amassada de identificação de rua, onde lemos Avenida Almirante Barroso. Única via de entrada e saída da cidade de Belém no estado do Pará, esta avenida possui histórias das mais diversas referentes à violência no trânsito da cidade. A placa, coletada pela

18 "Graduada no curso de licenciatura em artes plásticas pela Universidade Federal do Pará. Expôs no Centro Cultural Banco do Nordeste (Fortaleza, CE); no XI Enearte (Rio de Janeiro, 2007) e no XII Enearte (Belém, 2008) na I Bienal de Fotocópias (Argentina, 2009). Suas obras fazem parte dos acervos: CCBNB (Forteleza, CE); Fundação Rômulo Maiorana (Belém, PA); Sistema Integrado de Museus e Memoriais (Belém, PA) E Fundação Getúlio Vargas (Belém, PA). Foi contemplada com os prêmios: SIM de Artes Visuais 2008 e aquisição no $27^{\circ}$ Arte Pará e Bolsa de Pesquisa, Experimentação e Criação Artística do Instituto de Artes do Pará, 2009." Fonte: www.itaucultural.org.br. 
artista após um acidente automobilístico, evidencia a maneira caótica como estamos inseridos e subordinados aos elementos dessa cidade em um trânsito que nos torna cada dia mais inaptos de regermos nossas próprias decisões vitais.

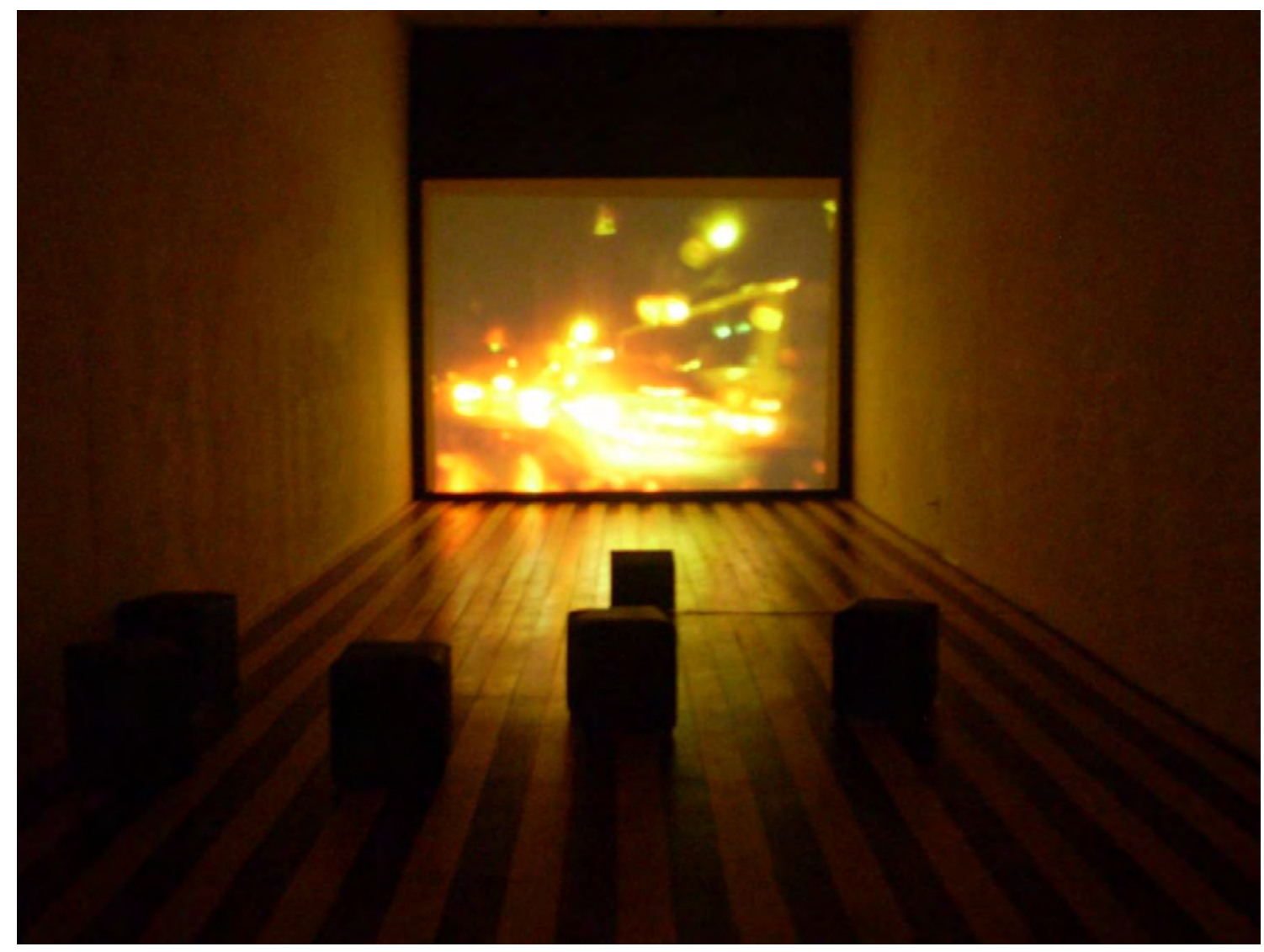

Ilustração 33: Registro da obra Cidades Vulneráveis (2008) de Carla Evanovitch exibida em exposição homônima na Sala Gratuliano Bibas do Museu Casa das Onze Janelas em Belém-PA no ano de 2008.

Fonte: Acervo do projeto de pesquisa "Acervo de Videoarte paraense: sistematização e análise crítica" (CNPq/SEC/MinC - 2014-2016).

Foto: Murilo Rodrigues

O vídeo de trinta e quatro minutos exibe imagens do percurso ao longo da citada avenida até o município de Ananindeua, este geograficamente conurbado à cidade de Belém, portanto vemos questões referentes a limites entre espaços, e como este designam identidades locacionais. A partir do espaço expositivo somos transportados ao trajeto completo pela avenida até chegarmos a uma situação de conforto, o lar, como um clímax poético. Como descreve Carla Evanovitch (2008), “... o trabalho é o registro e o fragmento de uma cena que se refere à vulnerabilidade presente na cidade" 19 .

\footnotetext{
1919 Citação retirada do dossiê do citado trabalho, cedido pela artista para compor o acervo desta pesquisa.
} 
A cidade aqui é tratada para além de uma abordagem coletiva, é também intimista e subjetiva. O percurso narrativo que Evanovitch nos apresenta é seu próprio percurso físico sensível, a narrativa mais que conta, divide conosco a história. Um percurso realizado diariamente por muitos cidadãos se torna vital à artista, denunciado em seus perigos e compartilhado em suas imagens de naturezas distintas. Desfocado e em movimentos rápidos, como integrante da aceleração cidade-trânsito, o vídeo, gravado em plano-sequência, é interrompido na edição por frases que deliberam sinalizações de um estado de espírito da própria artista e nos incita posições sensoriais ao pedir: "aguce os ouvidos", ou que enxerguemos "uma outra paisagem", solicita um outro olhar para a cidade, crítico e reflexivo. A imagem desfocada e a instabilidade da câmera instituem semelhanças com a obra Alegoria (2012) do Coletivo Madeirista citado em nosso segundo capítulo. Principalmente as luzes dos automóveis e dos postes da rua se tornam a partir desfoque, em alguns momentos, apenas elementos de cor que se movimentam no quadro e se distanciam de seu referente.

A inserção dessa abordagem mais abstrata faz surgir uma situação importante. Se por um lado vemos a tela ao fundo da sala sugerir uma espécie de prolongamento do espaço por meio de uma imagem perspectivada desse percurso na cidade, por outro vemos um desvio constante dessa relação por meio dessas espécies de abstrações, que dotam o espaço de uma abordagem muito mais sensorial, potencializada pelo áudio com um volume alto do trânsito dessa cidade. $\mathrm{O}$ espaço, que corresponde a tudo o que não é projeção, se transforma em um ambiente de sensorialidade pelas cores que se estendem nas paredes, no chão e no teto a partir de uma reverberação daquele único ponto luminoso, a tela, e o som que ganha uma potencialidade extra na constituição do vazio desse espaço.

A sala dispõe ainda de alguns bancos que pressupõem aquela tentativa de oferecer para o público um certo conforto ao corpo na experiência de visualização da longa duração do vídeo, mas, ao mesmo tempo, os cortes compostos pelas frases citadas anteriormente inserem uma perspectiva de fragmentação da narrativa e mesmo divisão ou encorajamento da fruição do trabalho por meio de uma entrada e saída constante do espaço. Uma experiência construída por meio do excerto como fruição veloz de sensorialidade, e a longa duração como experiência do corpo sentado, calmo e que volta sua atenção para esse ponto alto do ambiente constituído pelo vídeo projetado na tela. 


\section{$16 \mathrm{KM}$}

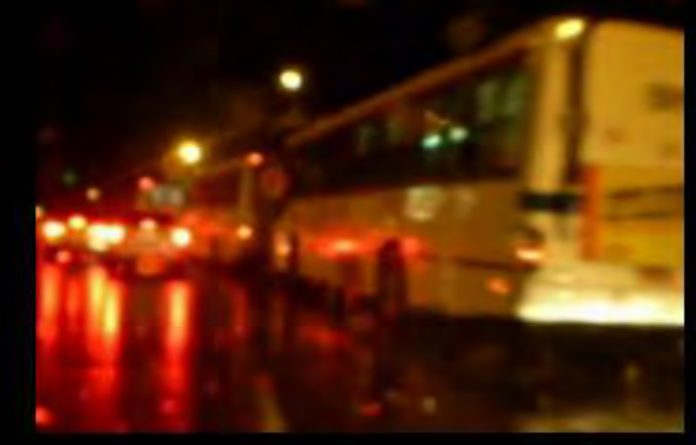

$03^{n}$

$07^{\prime \prime}$

$30^{\prime \prime}$

$21^{\prime} 13^{\prime \prime}$
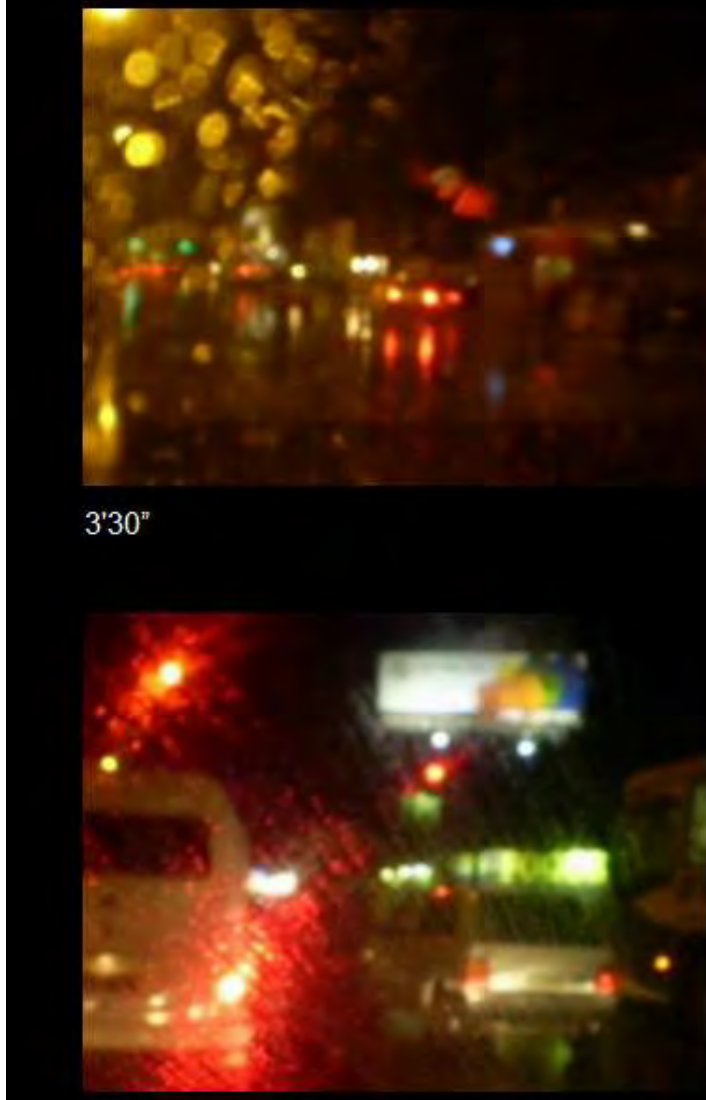

\section{PROSSIGP}

$12^{\prime} 31^{\prime \prime}$

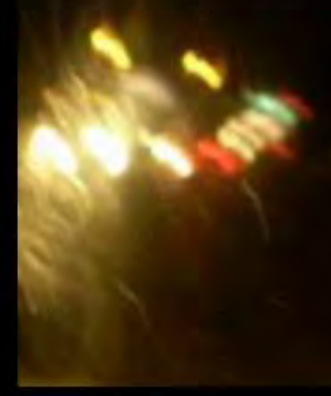

$23^{\prime} 29^{\prime \prime}$

Ilustração 34: Frames do vídeo Cidades Vulneráveis (2008) de Carla Evanovitch Fonte: Acervo do projeto de pesquisa "Acervo de Videoarte paraense: sistematização e análise crítica" (CNPq/SEC/MinC - 2014-2016). 
Essas mesmas características de organização espacial estão presentes na obra intitulada Clyde Reflections (2015) de Stephen Hurrel ${ }^{20}$, constituído por uma única projeção no fundo do espaço da galeria. A diferença que gostaríamos de apontar aqui se refere à abordagem narrativa desse trabalho. Enquanto Evanovitch compõe o vídeo a partir desse jogo entre o abstrato e o figurativo, Hurrel se atém à criação de uma espécie de documentário experimental com imagens gravadas em altíssima resolução.

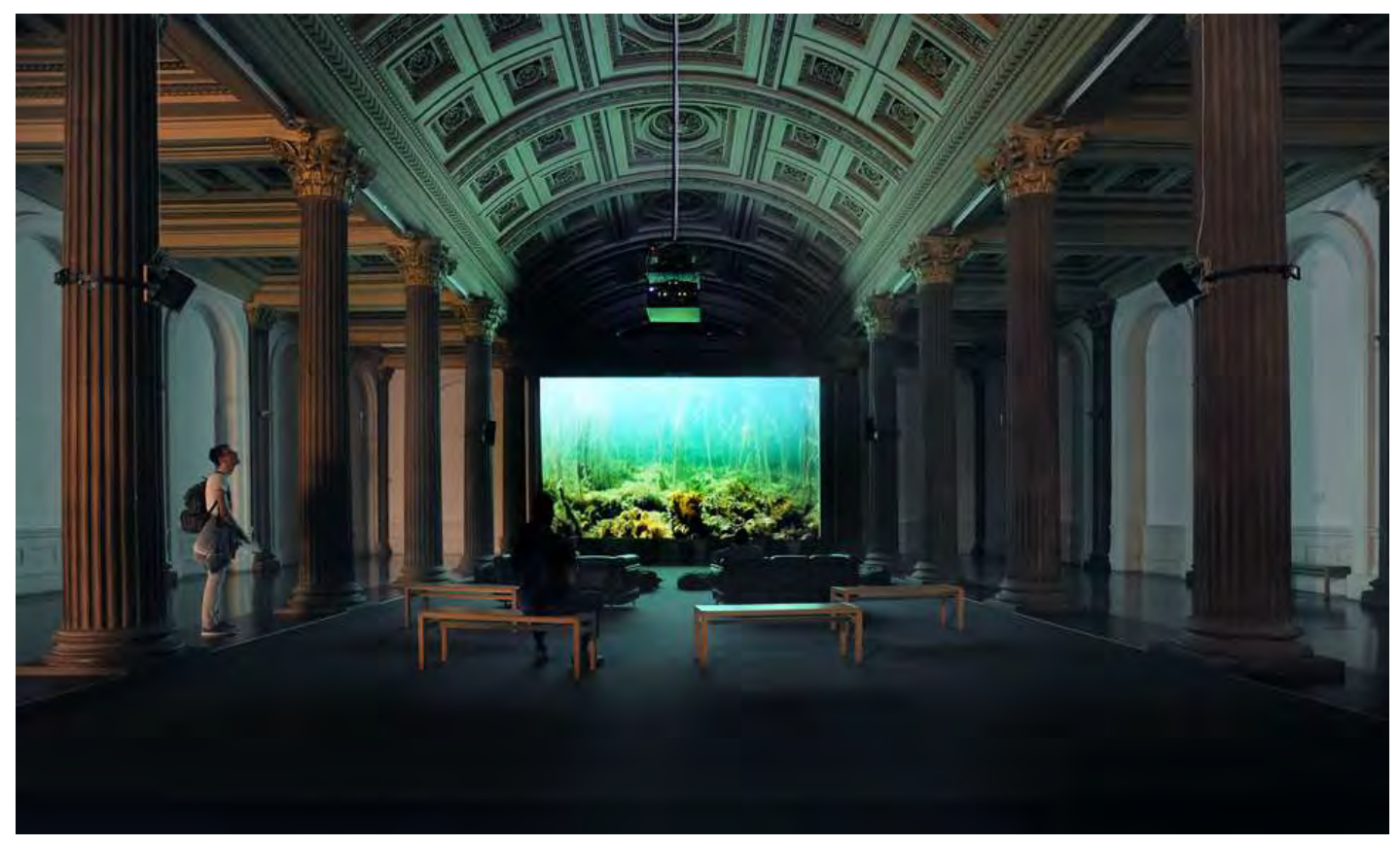

Ilustração 35: Plano de exibição da obra Clyde Reflections (2015) de Stephen Hurrel em exposição que aconteceu no ano de 2015 na Gallery of Modern Art em Glasgow (Escócia)

Fonte: Acervo pessoal do artista

$\mathrm{O}$ artista se apropria principalmente do depoimento, como um signo dessa vertente do documentário, e utiliza um jogo de dialéticas entre imagens e entre som e imagem para discutir questões referentes a relação entre ser humano e meio ambiente, tomando como objeto de estudo o braço de mar do Rio Clyde, um dos maiores da Escócia e que corta a cidade de Glasgow, onde vive o artista. A sua relação com este rio é, portanto, da ordem da proximidade cotidiana, e daí surge a vontade de explorar e conhecer sua fonte e desnudar o seu interior.

20 "Vive e trabalha em Glasgow (Escócia), é graduado e pós-graduado em artes plásticas pela Glasgow School of Art (1984-1989). Trabalha com vídeo, arte sonora, escultura combinando arte, ciência e tecnologia para explorar e registrar as tensões entre natureza e a sociedade contemporânea. Exposições e projetos incluem: Sea Change, Royal Botanic Garden, Edinburgh (2013); Mapping the Sea: Barra, Cape Farewell Comission, Barra (2012); Turbulent Terrain, Latrobe Gallery, Australia (2009); Beneath and Beyond, Tramway, Glasgow (2008)". Fonte: www.generationartscotland.org. 

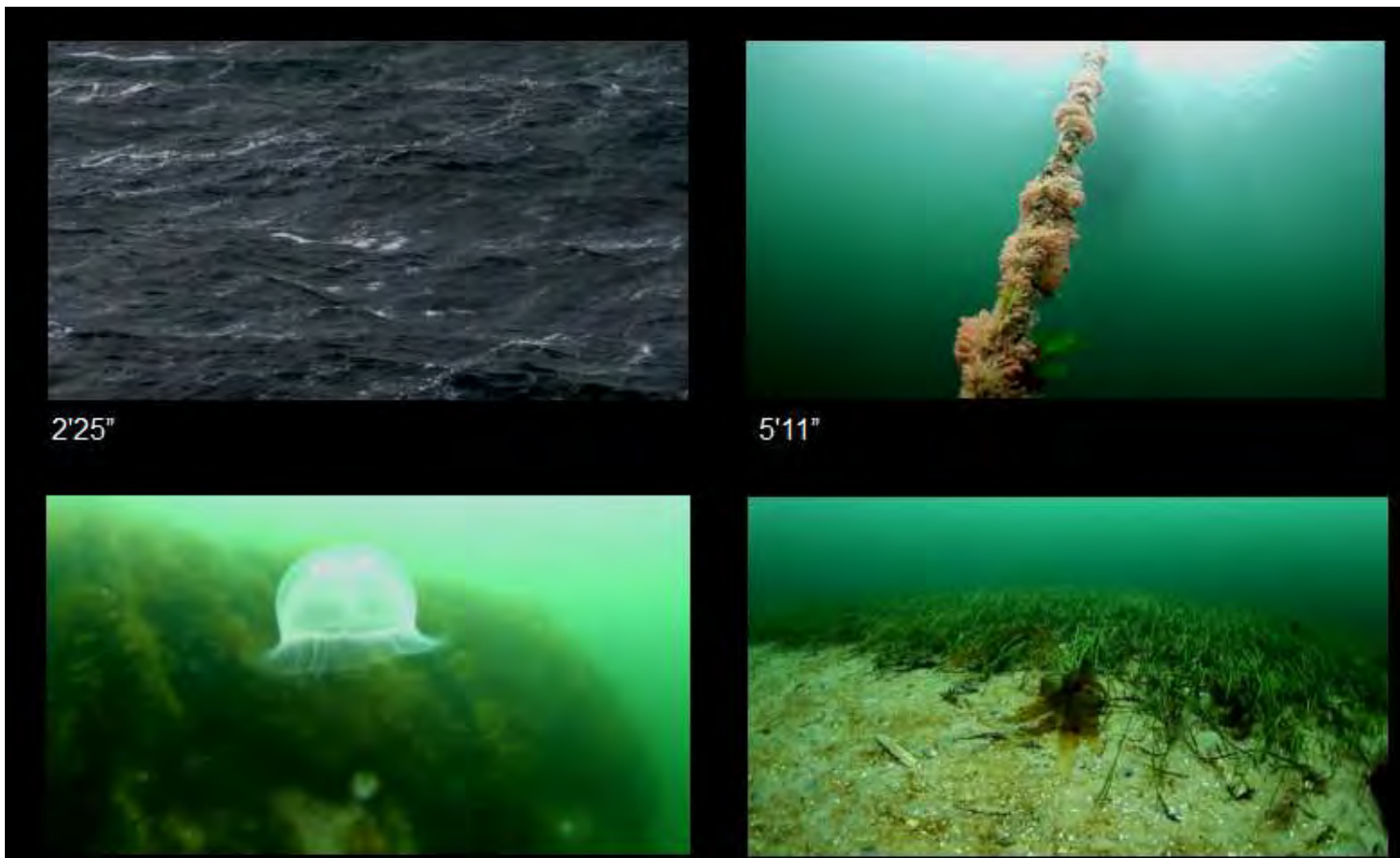

$6^{\prime} 38^{\prime \prime}$

$7^{\prime} 57^{n}$

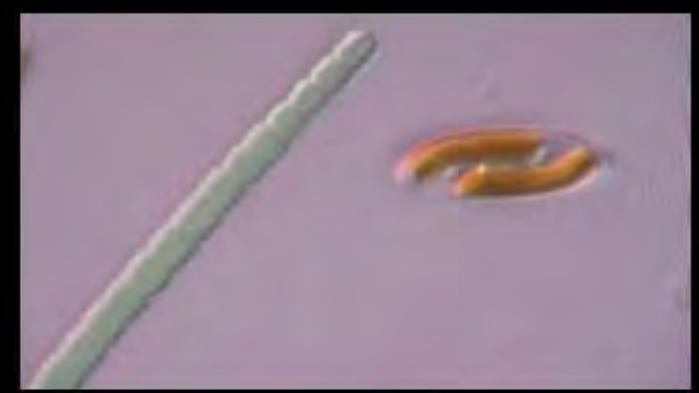

$12^{\prime} 11^{n}$

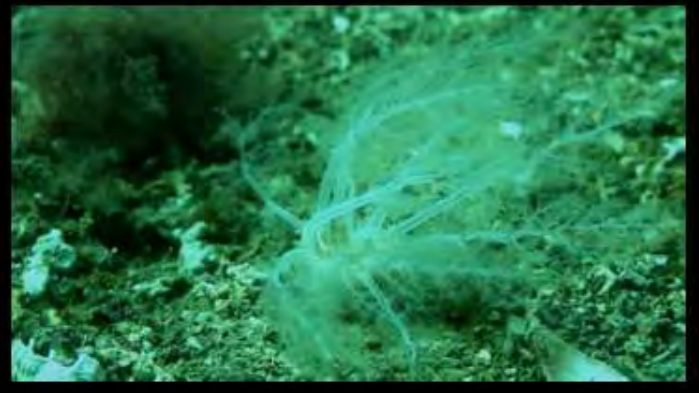

\section{$170^{\prime \prime}$}
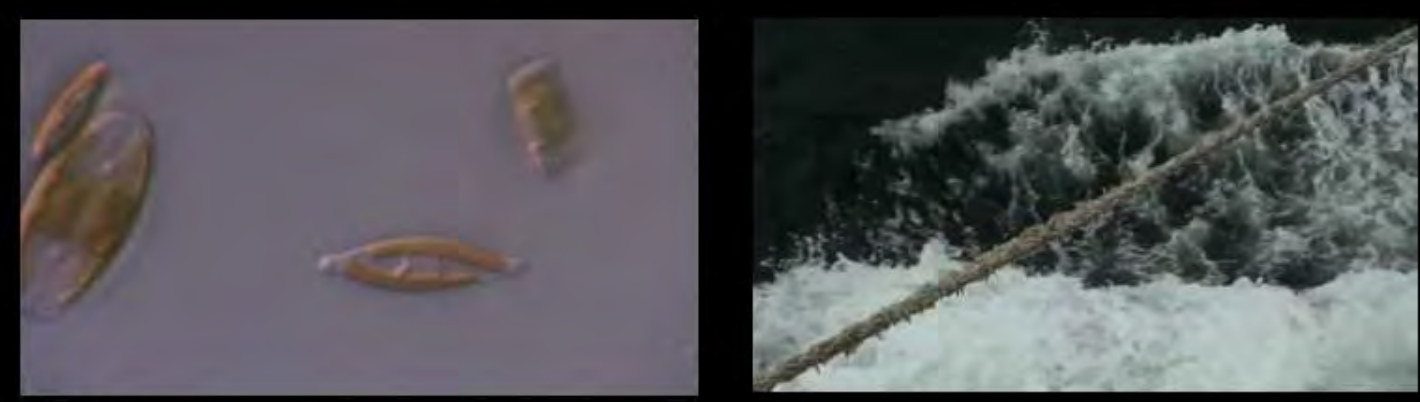

$27^{\prime} 50^{\prime \prime}$

Ilustração 36: Frames do vídeo Clyde Reflections (2015) de Stephen Hurrel

Fonte: Acervo pessoal do artista 
Nesse trabalho, que Hurrel classifica como uma experiência cinemática meditativa, a definição do que seria "natural" e "não-natural" no braço de mar do Rio Clyde se torna uma espécie de pergunta gancho para a gravação dos depoimentos de uma série de pessoas de origens diversas, entre elas um biólogo marinho, um mergulhador, um conservacionista marinho, um líder espiritual e um oceanógrafo físico, que conferem abordagens muito diferenciadas a essa relação. O áudio desses depoimentos aparece durante o vídeo inteiro, em que a alternância entre imagens da superfície e das profundezas dessa porção de mar compõem essa dualidade entre o natural e as intervenções sobre ele. Nessas profundezas imagens de corais, plantas e organismos marinhos se apresentam, também intercaladas por imagens microscópicas desses organismos vivos. O vídeo é uma espécie de projeto artístico-científico que deflagra as características dessa vida marinha de modo poético.

Estas para nós são as duas principais recorrências nesse tipo de trabalho em que uma tela única de projeção se apresenta: por um lado a constituição de imagens que levam muito mais a uma experiência sensorial com a tela grande, e por outros trabalhos que questionam a narrativa cinematográfica tradicional apropriando-se de alguns aspectos dela, como nesse documentário experimental de Hurrel.

Ainda nesse modo de espacialização uma fragmentação da imagem acontece para além do quadro, na multiplicação de telas projetadas, mantendo ainda características como a necessidade da sala escura. Essa vertente aparece, por exemplo, nos trabalhos Buruburu (2011) de Ayrson Heráclito e Santoscópio = Dumontagem (2011) de Carlos Adriano ${ }^{21}$. No primeiro trabalho, instalado em um ambiente escuro, identificamos a primeira vista uma imagem com dois quadros: à esquerda um plano fechado de pipocas estourando, à direita um homem negro surge como se estivesse saindo dessa imagem das pipocas. Essa figura masculina se posiciona no centro do quadro e encara a câmera até que pipocas começam a cair da parte superior da imagem, momento em que ele abre os braços e os movimenta numa espécie de êxtase que remete também a uma ação de adoração. Buruburu, segundo sinopse do trabalho, se refere a pipoca em dialeto afro-brasileiro e também a flor do orixá Obaluaê.

A ação desse homem metaforiza, portanto, um derramamento conceitual dessa entidade na sua corporeidade, fundação de identidade por meio do contato com essa espécie de chuva de

21 "Cineasta e doutor em cinema pela Universidade de São Paulo, sua obra comprometidamente experimental lida com fragmentos obscuros da memória artística e cultural brasileira. Seus dez curtas e um longa-metragem foram vistos em festivais e mostras no Brasil, Nova York (EUA), Berlim (Alemanha), Bilbao (Espanha), Bologna (Itália), Chicago (EUA), Paris (França) e Roterdã (Holanda), entre outros. Foi bolsista da Fundação Vitae e destaque do eixo Cinema + Artes +Vídeo do $16^{\circ}$ Videobrasil (2007). Com Bernardo Vorobow, é autor do livro Peter Kubelka: A essência do cinema (2002) e organizador de Julio Bressane: CinePoética (1995)". Fonte: www.videobrasil.org.br. 
pipoca que toma o espaço do quadro. A relação entre as telas se dá justamente nesse aspecto de continuidade entre o elemento pipoca que toma o quadro à esquerda inteiro e que se derrama no corpo à direita. $\mathrm{O}$ trabalho simula por meio de projeções diferentes desses dois vídeos aquele jogo de janelas eletrônicas de que já falamos, o splitscreen, e o próprio espaço físico expositivo é objeto da espacialização. Enquanto esse jogo de janelas nas propostas mono-canal só pode existir pelo processo de edição, nessas outras propostas ele se funda no jogo de estreitamento físico entre as linhas de enquadramento das luminâncias da projeção em dada superfície.

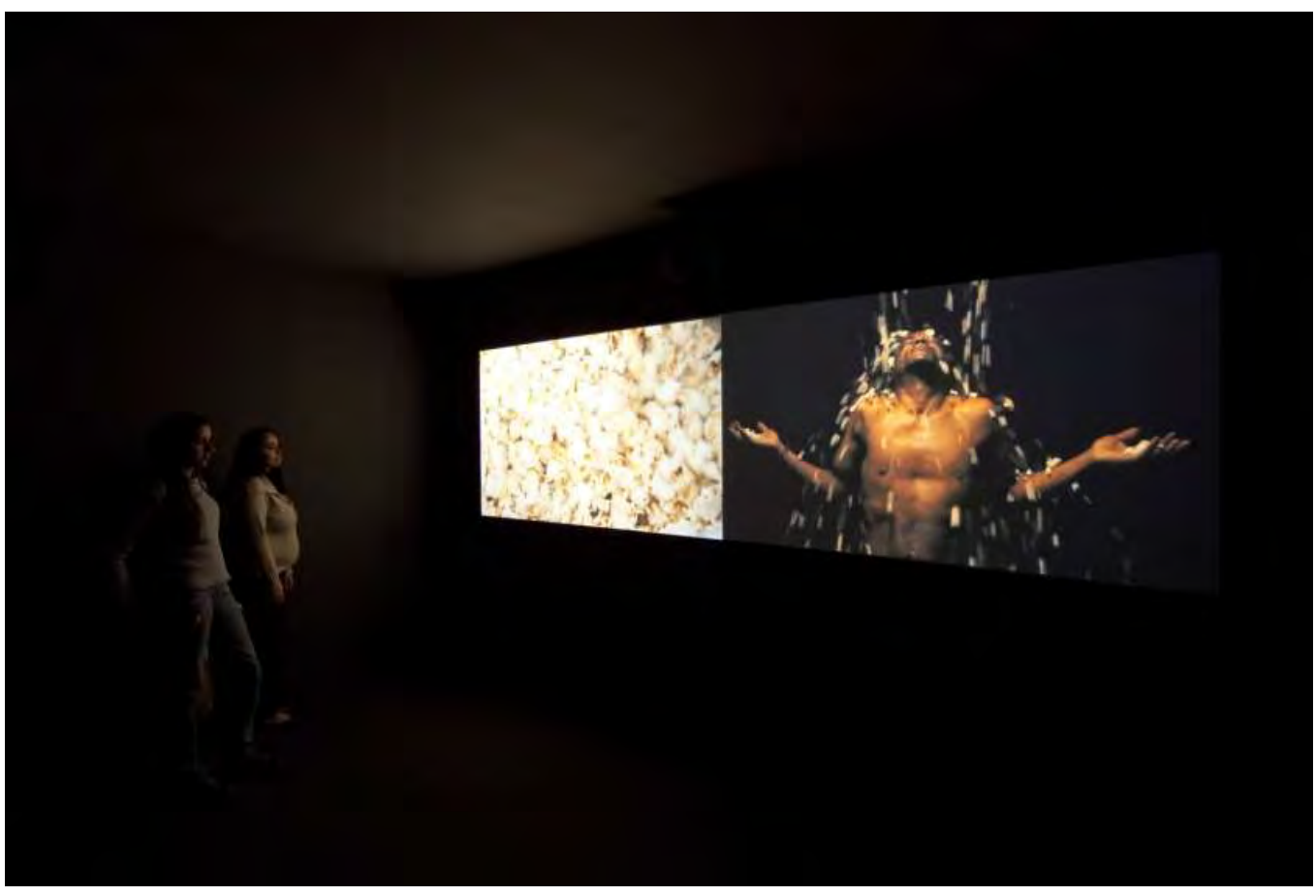

Ilustração 37: Registro da obra Bururu (2011) de Ayrson Heráclito instalada no Sesc Belenzinho (São PauloSP) durante o $17^{\circ}$ Festival de Arte Contemporânea Videobrasil em 2011.

Fonte: Acervo da Associação Cultural Videobrasil

Foto: Everton Ballardin

De maneira mais radical nessa multiplicação de telas Carlos Adriano apresenta Santoscópio $=$ Dumontagem (2011). Segundo sinopse o trabalho é composto por uma apropriação de imagens de mutoscópio (um aparelho dos primeiros anos do cinema) de Santos Dumont. Nesse filme, intitulado Santos Dumont Explaining His Airship to the Hon. C. S. Rolls, datado de 1901 e com 52 segundos, Santos Dumont apresenta uma de suas invenções a Charles Rolls, um inglês pioneiro no território da aviação. Essas imagens foram encontradas por Carlos Adriano no Museu Paulista da Universidade de São Paulo e se tornaram matéria-prima para a construção desse trabalho em vídeo que reconfigura essa estética do primeiro cinema. 


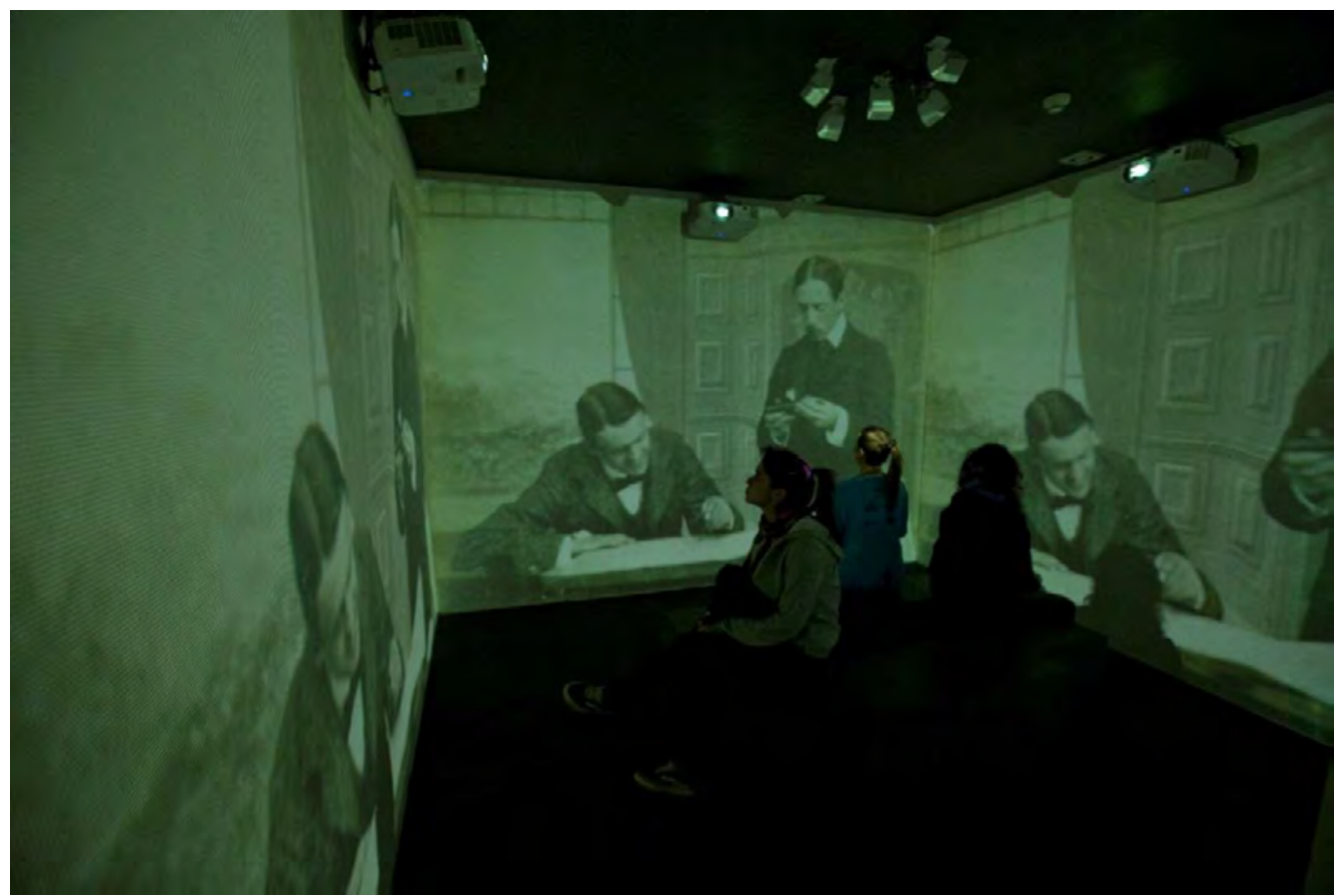

Ilustração 38: Registro da obra Santoscópio = Dumontagem (2011) de Carlos Adriano instalada no Sesc Belenzinho (São Paulo-SP) durante o 17 Festival de Arte Contemporânea Videobrasil em 2011.

Fonte: Acervo da Associação Cultural Videobrasil

Foto: Everton Ballardin

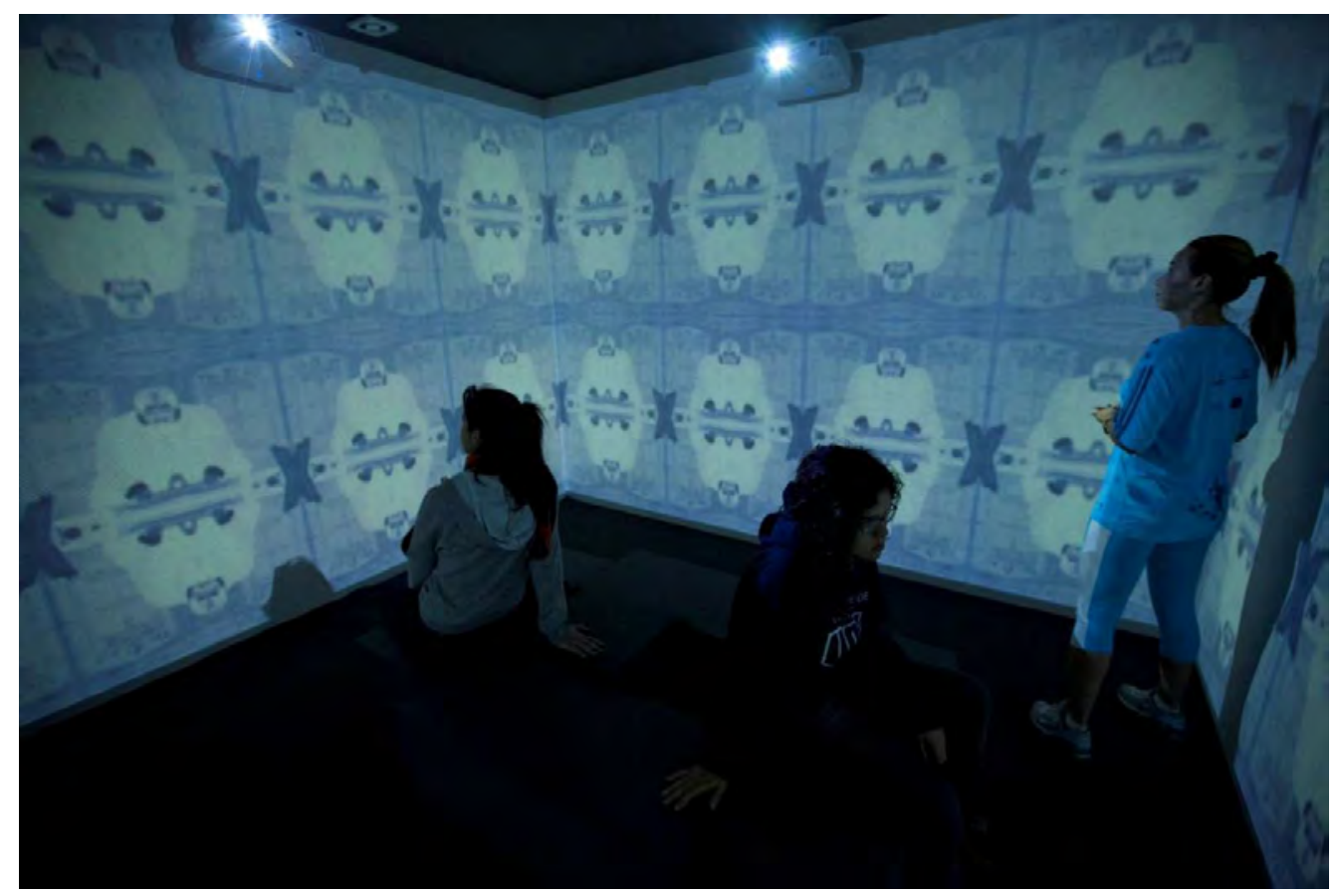

Ilustração 39: Registro da obra Santoscópio = Dumontagem (2011) de Carlos Adriano instalada no Sesc Belenzinho (São Paulo-SP) durante o $17^{\circ}$ Festival de Arte Contemporânea Videobrasil em 2011.

Fonte: Acervo da Associação Cultural Videobrasil

Foto: Everton Ballardin 


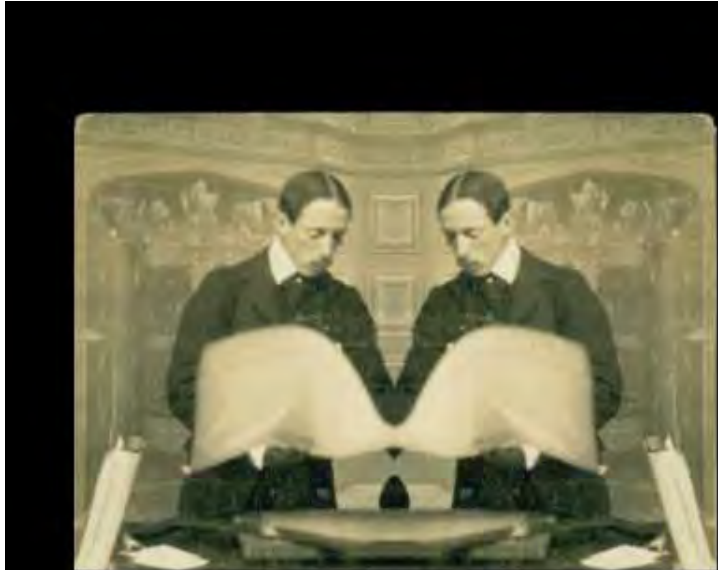

$2^{\prime} 10^{\prime \prime}$

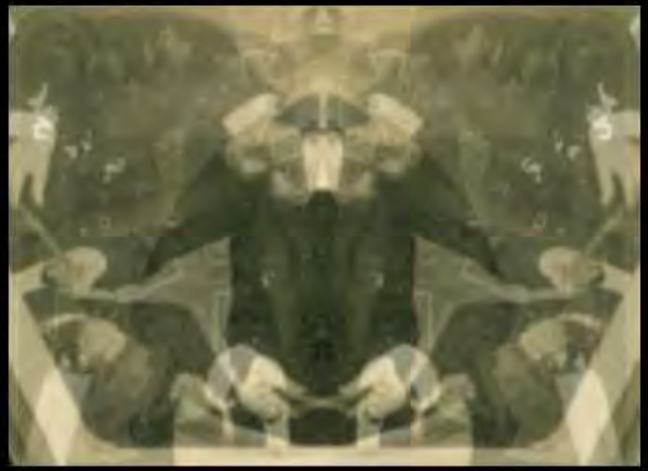

$5^{\prime} 04^{n}$

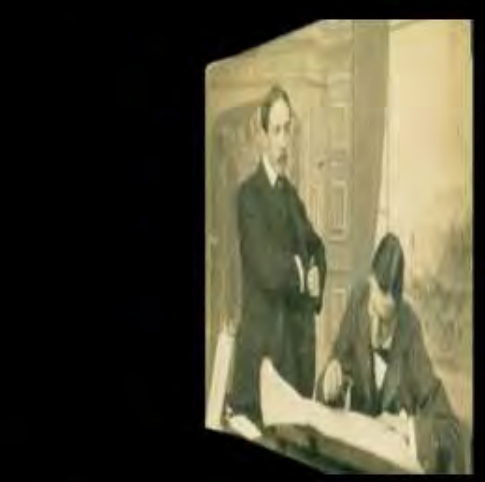

$9^{\prime} 44^{\prime \prime}$

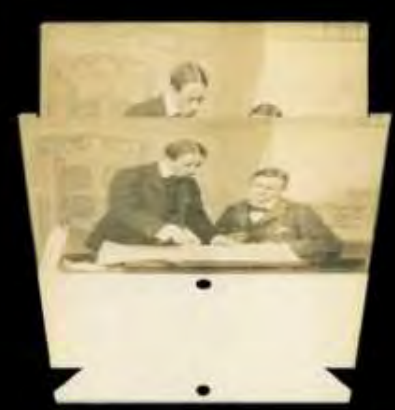

$3^{\prime} 05^{\prime \prime}$

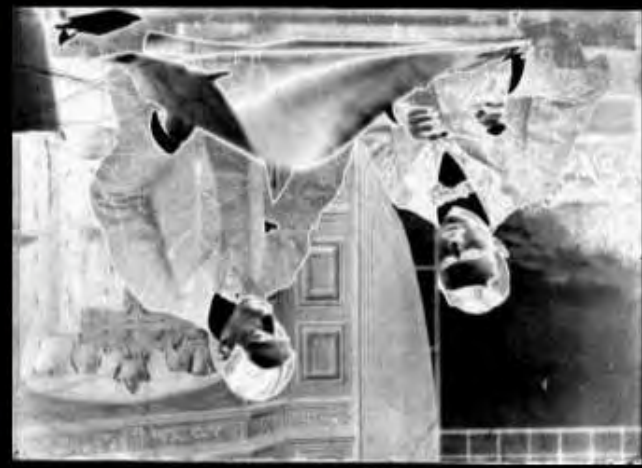

$6^{\prime} 28^{\prime \prime}$

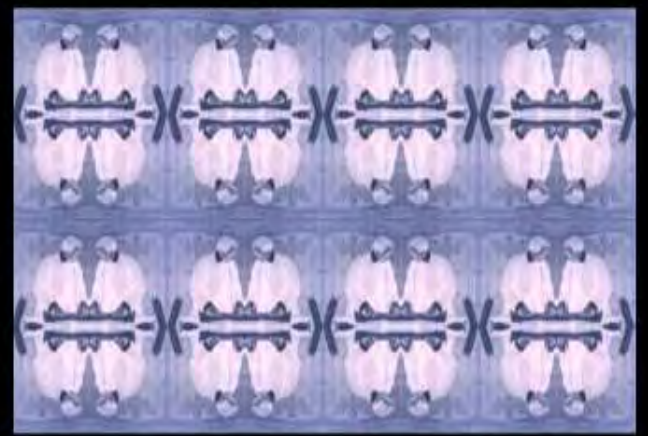

$12^{\prime} 47^{n}$

Ilustração 40: Frames do vídeo que compõe a obra Santoscópio = Dumontagem (2011) de Carlos Adriano Fonte: Acervo da Associação Cultural Videobrasil 
O vídeo é construído por modificações na imagem original materializadas por uma alternância entre o negativo e o positivo, a apresentação de uma cintilação constante que parece simular características do primeiro cinema, colorizações diferentes, inversões, a simulação da sucessão de imagens no mutoscópio, a repetição dessa imagem em pequenos quadros dentro do quadro maior que compõe uma tela em uma espécie de caleidoscópio. Carlos Adriano retoma aqui aquela discussão da instituição de uma sensorialidade proporcionada pelo espaço como um dos principais objetivos, para além do âmbito narrativo da ação efetuada por Santos Dumont que é também reconfigurada pela composição de quadros dentro do quadro.

O ambiente é aqui apresentado com três projeções, uma em cada parede. O espaço de instalação, dominado pelas projeções, torna-se uma espécie de tela tridimensional onde o espectador entra e mergulha nessa profusão de luminâncias que o rodeiam. As linhas que dividem fisicamente cada umas das paredes coincidem fisicamente com as bordas das imagens que dividem cada uma das projeções, imagem e o espaço da arquitetura compartilham os mesmos limites. Nesse trabalho aquele esmagamento do qual Aumont fala a respeito das imagens em grande dimensão toma forma potencial. A sensação de imersão causa nesse público uma espécie de desconforto visual pelo bombardeamento da luz e da cor, pede um deslocamento, uma circularidade e movimento do próprio corpo para apreensão da totalidade das imagens projetadas. O Áudio do ambiente, constituído por três canais diferentes de cada vídeo se intercalam constantemente, o que sugere um abandono da visualização de uma imagem para outra a cada troca de canal de som. A apropriação, modificação e apresentação desse registro, que segundo o autor se confunde com a própria história do cinema, parece instituir aquele eterno retorno de que fala Vilém Flusser (2009), em que o antes se torna depois e o depois se torna antes em processo contínuo. Essa situação, ainda segundo Flusser, funda aqui um tempo de magia para a imagem, que se difere de um aspecto linear da história, constituindose como narrativa circular em que um elemento existe por explicar o outro ao mesmo tempo que é explicado pelo primeiro.

O que verificamos nesse modo de espacialização é, portanto, a utilização da projeção, saída do monitor como único elemento de apresentação do vídeo. Essa saída não é, no entanto, uma simples alternativa de exibição, funda uma espacialidade de dominância da imagem sobre o corpo do espectador e retoma certos aspectos de uma experiência cinemática. Em função da sala escura, a apresentação de uma única tela como ponto primordial constrói o ambiente por meio da extensão de sua luminância em direção às paredes, ao chão, ao teto e ao corpo do espectador. No mesmo sentido, o processo de multiplicação dessas projeções agrega camadas de significação e também de luminâncias que se confrontam no espaço da galeria e afetam 
potencialmente o próprio corpo do espectador, ao ver essas imagens algumas vezes projetadas em si em função do cruzamento dessas projeções em que a sua presença inevitavelmente interfere imageticamente.

\subsubsection{SEGUNDO MODO: VÍDEO-CENÁRIO}

Neste modo de espacialização continuamos a indicar esse processo de fundação de ambientes, ocupação de galerias ou salas inteiras com um único trabalho, que agora não existe mais apenas pela instalação da projeção de video, seja em seu estado unitário ou multiplicada. Verificamos em trabalhos desse tipo duas vertentes: a utilização do vídeo projetado em grandes dimensões e a utilização de mais de um monitor para a exibição de vários vídeos. Além disso esses ambientes são construídos também naquela mesma relação que indicamos na vídeodistensão, a da inclusão de objetos enquanto extensões da narrativa do vídeo. A diferença entre o vídeo-cenário e a video-distensão reside no fato de que este último está geralmente atrelado à exibição na parede ou formas esculturais em que aquela dominância física da escala do corpo do espectador ainda existe, enquanto no primeiro essas extensões existem como elemento que preenche essa sala como um todo, seja pela sua escala ou pelo acúmulo de uma grande quantidade de objetos dispostos ao longo de todo o espaço.

Importante salientar que quando utilizamos o termo cenário não falamos de situações em que o vídeo aparece como elemento cenográfico no âmbito de espetáculos de teatro e dança, por exemplo. Em outro viés nos referimos a uma situação que Nicolas Bourriaud (2009) aponta, o da transição da exposição-vitrine, em que objetos em uma sala podem ser visualizados individualmente sem que haja uma interferência direta entre eles, para a exposição-cenário, onde o que funda o espaço é justamente a relação unificadora de significação entre esses objetos. Obviamente cada objeto trará também uma significação própria, mas o argumento poético do trabalho é potencializado pelo pensamento da relação entre eles, que podem se tornar destituídos de seu significado nesse estado se pensados apenas como unidade.

Esse entendimento unificado parece só poder existir nesses trabalhos pela potencialização do abandono do lugar apontado por Merleau-Ponty, na construção de planos de espacialidade que se modificam pelo posicionamento e construção e deslocamento do estado de profundidade pelo corpo do espectador, no jogo entre a proximidade e a distância dos objetos que compõem esse ambiente. O público é convidado a percorrer esse espaço para se entremear aos objetos ou movê-los ao mesmo tempo em que mantém uma atenção ao vídeo exibido no 
monitor ou projeção. Aquela dispersão de que já falamos existe para além de uma situação mais geral da galeria, o próprio conteúdo dos trabalhos se baseia nesse princípio.

Essas relações podem ser visualizadas em Patterns (2015) de Bonnie Camplin²2. O ambiente da galeria é composto pelo seguinte conjuntos de elementos: 1) Cinco monitores dispostos em forma de pentágono em cima de uma mesa branca que se localiza no centro da sala; 2) Uma espécie de bancada formada por mesas encostadas nas paredes da galeria e que a rodeiam quase por completo, onde vemos depositadas em sua superfície uma série de livros, impressos de internet, fotografias e documentos; 3) Uma máquina de cópias coloridas.

Cada um desses cinco monitores exibe um vídeo retirado de sites da internet com depoimentos de pessoas que relatam experiências de contatos com extra-terrestres, experiências espirituais e teorias de conspiração militar para o encobrimento dessas situações ditas paranormais, com os áudios isolados pela utilização de fones de ouvido. Um dos vídeos é integrante do Project Camelot, que busca, registra e disponibiliza uma série de entrevistas com pessoas que falam acerca de sociedades secretas que se instituem hoje e suas relações com dimensões físicas que vão para além das nossas. Nesse vídeo uma mulher fala de um projeto secreto do governo britânico que permitiu que ela e seu pai entrassem em diversas dessas dimensões paralelas, e ao retornar a esse mundo relata como esse processo constituiu uma certa perda de identidade no âmbito psicológico e político. Seu pai, por exemplo, já falecido, teve todos os documentos que registrariam a sua existência, tais como a certidão de nascimento, completamente eliminados dos registros oficiais no país, uma tentativa do governo de esconder a existência desse projeto.

Dispostos nesse formato de pentágono, o arranjo dos monitores deixa implícita a relação com um dos principais órgãos governamentais de outro país, os Estados Unidos (que é alvo de várias teorias de conspiração sobre essas situações citadas), um símbolo dessa relação de encobrimento rememorado pela artista como um processo que acompanha a história da humanidade na tentativa de esconder de uma sociedade dita saudável esses desvios de normalidade. Camplin joga aqui com a nossa própria percepção de realidade, problematiza o limite entre o normal e o anormal, o verdadeiro e o falso, que nós mesmos conferimos a esses depoimentos.

22 Nasceu, vive e trabalha em Londres, Inglaterra. BFA em Filme e videoarte pela Saint Martins School of Art (1992) e pós-graduada em Fotografia avançada na mesma instituição. Foi uma das artistas indicadas ao Turner Prize 2015. Fonte: www.artspace.com 


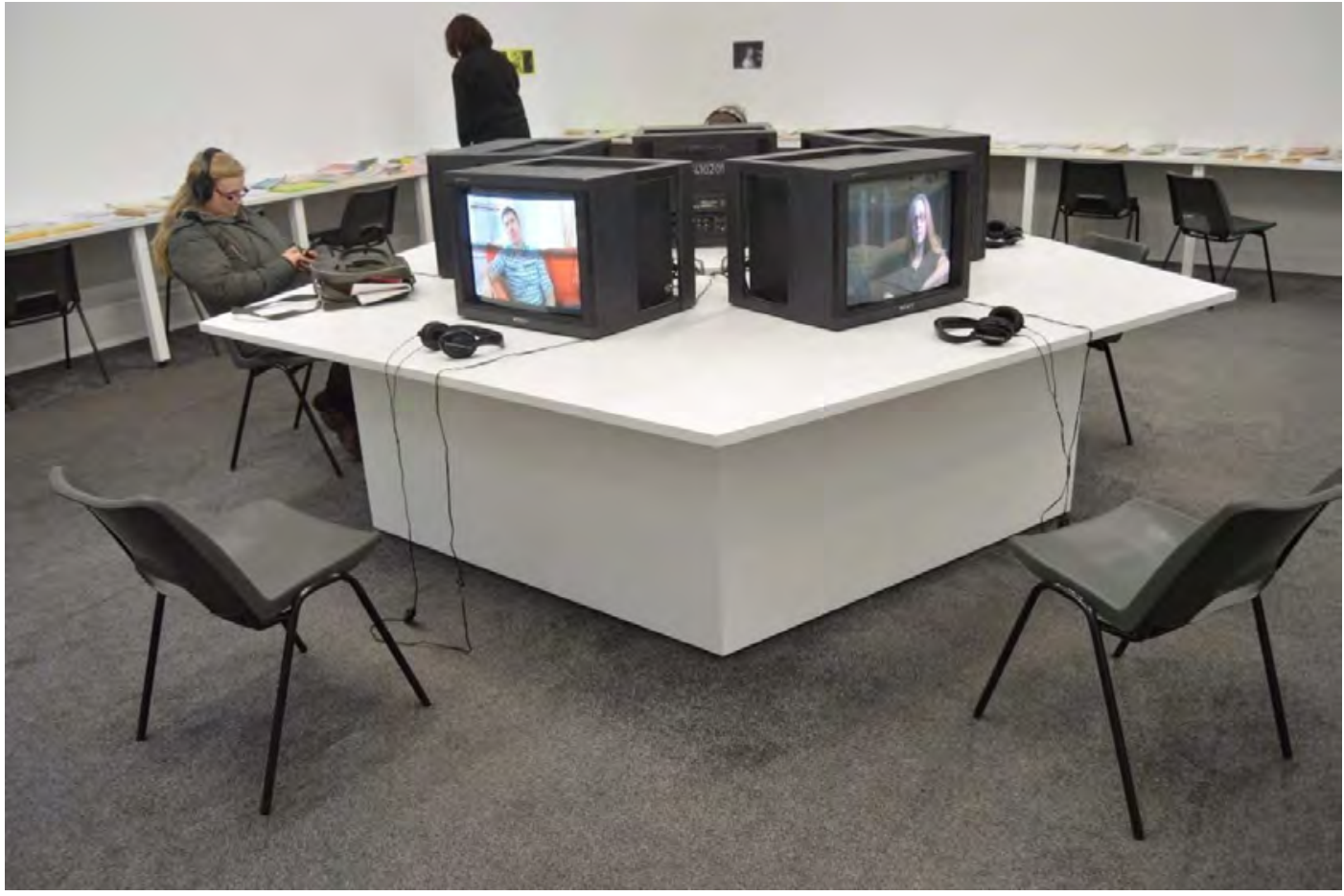

Ilustração 41: Registro da obra Patterns (2015) de Bonnie Camplin na Tramway Gallery em Glasgow (Escócia) durante a exposição do Turner Prize 2015.

Foto: Danilo Baraúna

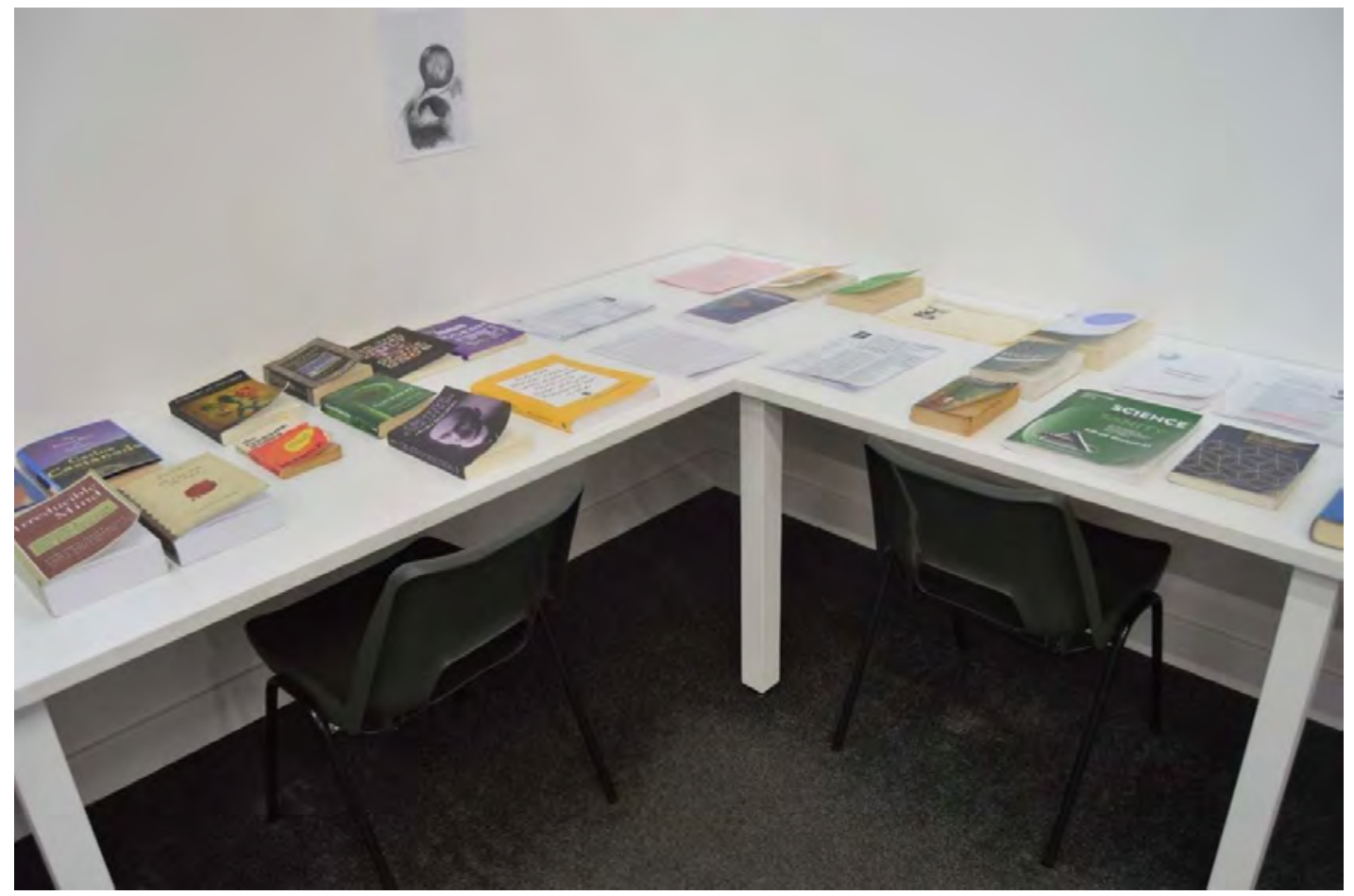

Ilustração 41: Registro da obra Patterns (2015) de Bonnie Camplin na Tramway Gallery em Glasgow (Escócia) durante a exposição do Turner Prize 2015.

Foto: Danilo Baraúna 
Todas essas questões são reforçadas pelos objetos dispostos na bancada. O que vemos são livros e textos impressos da internet que falam sobre neurociência, patologias cerebrais, depressão, ansiedade, livros clássicos como A História da Loucura (1972) de Michel Foucault, A Evolução Criadora (1907) de Henri Bergson e Alice no País das maravilhas (1865) de Lewis Carroll, fotos coladas nas paredes de pessoas e animais utilizando sensores $E E G^{23}$, livros de cosmologia e misticismo. Além disso, a fotocopiadora colorida permite que os visitantes copiem qualquer um dos conteúdos expostos. Bonnie Canplim compartilha conosco uma espécie de biblioteca colaborativa sobre todas as questões que já apontamos.

Nesse lugar a experiência de espaço e vídeo se dá também em uma direção fragmentada. A escolha por onde começar na visualização desses conteúdos é difícil em função da quantidade de informações presentes e o espectador o tempo inteiro pode variar entre a passagem por esses textos e leituras deles e o sentar nas cadeiras para assistir os vídeos por completo ou não. Os objetos aqui não necessariamente complementam de forma direta a narrativa ou os depoimentos em vídeo, como nos trabalhos de Val Sampaio ou Melissa Barbery, mas se referem muito mais ao contexto amplo de discussão que é instituído naquele ambiente e que perpassa tanto esses objetos quanto o conteúdo dos monitores. O ambiente silencioso, na medida em que o som só existe quando colocamos os fones de ouvido, confere uma atmosfera de tensão e medo que é também reforçado pelos conteúdos com os quais nos deparamos. O que vemos é, também, justamente essa constituição unificadora entre os objetos instalados no espaço a qual tentamos identificar, um ambiente que de fato se torna obra.

Abordagem parecida aparece em Crossing Points (2010) de Edwin Sanchez ${ }^{24}$, com alguns elementos que o diferem da proposta de Camplin. No ambiente o artista dispõe um total de três monitores, uma projeção, e alguns andaimes de construção civil. As diferenças citadas se apresentam por dois elementos: em primeiro lugar a inserção dessa projeção em diálogo com os monitores, e em segundo lugar a escala dos objetos de extensão incluídos no espaço. Os vídeos são constituídos por uma série de registros amadores de guerrilheiros colombianos confiscados por autoridades do país. Na projeção o vídeo apresentado esses guerrilheiros aparecem em uma floresta onde preparam armamentos em meio a uma quantidade significativa de notas de dinheiro, enquanto ouvem uma locução de rádio falando sobre uma exposição

23 Eletroencefalografia: eletrodos aplicados à cabeça registram em gráficos a atividade elétrica cerebral.

24 "Formado em belas-artes e design industrial em Bogotá, Colômbia, seu trabalho tem como tema-chave a complexa e violenta sociedade colombiana. Expõe individualmente desde 2007. Foi contemplado com seleção para o ICI'S Project 35 (Independent Curatros International, Nova York, EUA), para a mostra trienal Younger than esus (Nem museum, Nova York, 2008) e para o Pilot 3 - International archive for artists and curators (Londres, Inglaterra, 2010)”. Fonte: www.videobrasil.org.br. 
chamada Puntos de cruce, que segundo essa voz feminina do rádio é construída por uma discussão em torno de questões do íntimo, social e político. Em um dos outros monitores vemos o vídeo de um dos guerrilheiros apresentando um plano de invasão de um espaço, mostrando todos os caminhos seguros a serem percorridos, com atenção especial para os lugares em que se localizam postos militares.

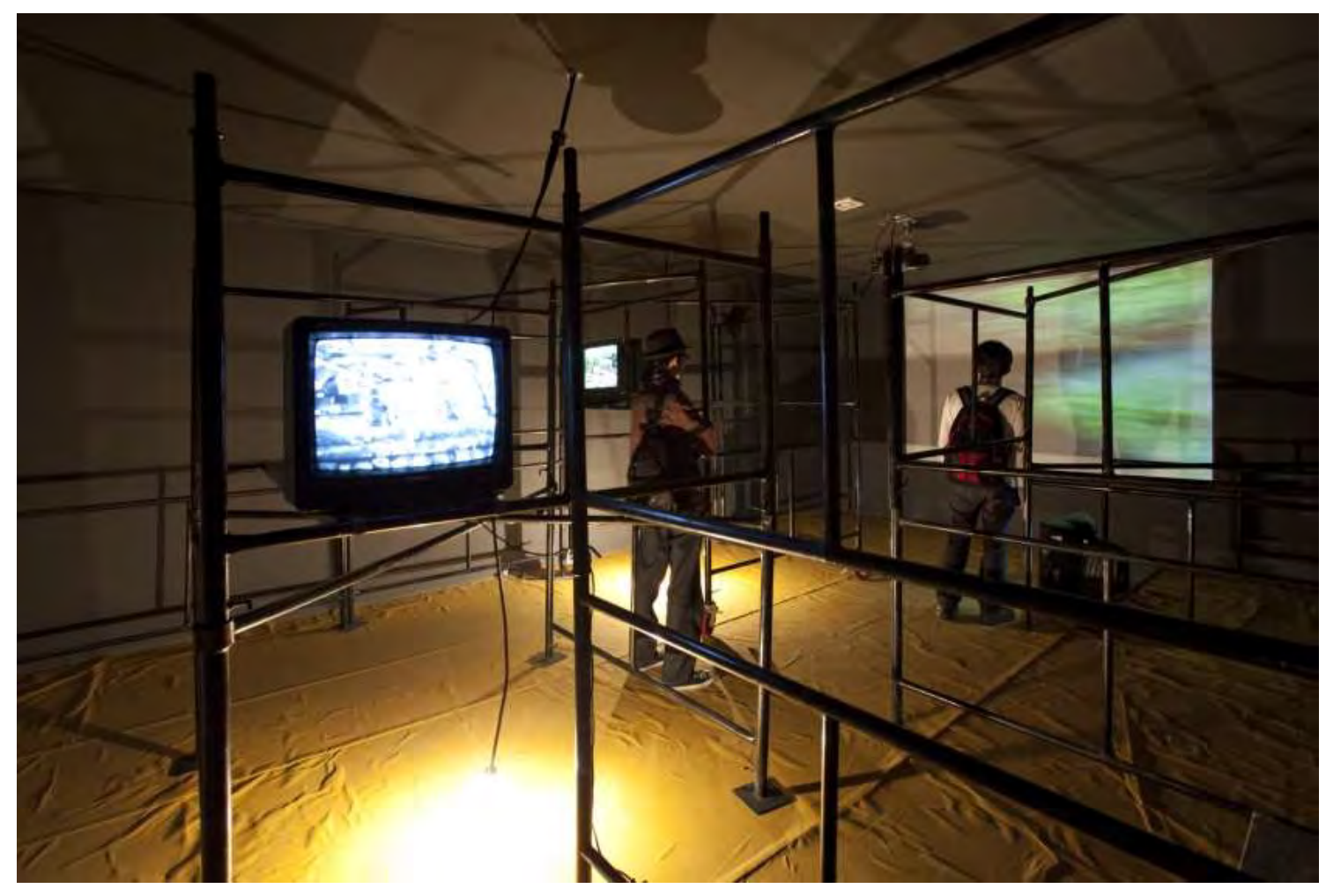

Ilustração 43: Registro da obra Crossing Points (2011) de Edwin Sanchez instalada no Sesc Belenzinho (São Paulo-SP) durante o $17^{\circ}$ Festival de Arte Contemporânea Videobrasil em 2011. Fonte: Acervo da Associação Cultural Videobrasil

Foto: Everton Ballardin

Outro monitor exibe o vídeo dos guerrilheiros tentando desatolar um caminhão em que estavam, indica a existência de um percurso que estava sendo realizado, enquanto o último vídeo trata-se de um confronto armado em uma área que parece ser uma pequena cidade. De maneira geral temos a impressão de que esse conjunto de vídeos mostra o plano e realização da ocupação daquele espaço que era planejado em um dos vídeos. A narrativa aqui é, portanto, dividida em quatro telas (três monitores e a projeção) com vídeos diferenciados que se apresentam em uma continuidade de significação na medida em que falam não apenas sobre si, mas sobre o próprio espaço em que estão instalados e a situação criada, onde a projeção parece 
ser o elemento de conclusão dessa história contada.

Aqui os andaimes tomam um aspecto de reformulação da arquitetura desse espaço incluindo uma atmosfera de construção e desconstrução que remonta o próprio processo de luta desses guerrilheiros frente a situação política de seu país. No espaço uma iluminação posicionada no chão permite a projeção de sombras desses andaimes e do corpo do espectador nas paredes e teto, construindo uma espécie de trama de linhas que existe na relação entre essa bidimensionalidade da sombra, a luminosidade da projeção de vídeo e a tridimensionalidade dos objetos (incluindo os monitores). Os andaimes dessa obra, diferente dos objetos incluídos no trabalho de Camplin, não podem ser manuseados, eles são de fato um tipo de estrutura arquitetural que em vez de solicitar uma mobilidade física do objeto, sugere muito mais uma mobilidade do corpo, uma construção dos percursos físicos para a visualização do vídeo e mesmo distâncias de contato com o espaço. O posicionamento desse corpo no ambiente pode se ater aos grandes espaços vazios deixados entre os andaimes, onde o corpo pode se colocar confortavelmente, mas também jogar com o movimento de se abaixar e levantar para a entrada na estrutura interna dos andaimes, cortados por essas barras de ferro que solicitam esse outro aspecto de deslocamento para que o corpo possa se integrar nesses lugares.

Outro trabalho que levanta as questões desse tópico é Performações urbanas (2009) de Carla Evanovitch, para quem a problemática urbana é essencial, conforme vimos em Cidades Vulneráveis (2008). Durante nove meses Evanovitch entrou nos transportes coletivos da cidade de Belém, no Pará, em busca das histórias de certos personagens urbanos. Esses personagens se tratam dos pedintes que todos os dias percorrem seus caminhos em vários coletivos apresentando suas histórias e normalmente solicitando ajuda financeira. A artista eleva a ação desses personagens a um status de performance, nos evidencia a clara problematização entre arte e vida, traz essas histórias para o espaço expositivo e nos propõe um caminho entre elas. O espaço é formado pela projeção de um vídeo em uma parede no fundo da sala, um pote de vidro posicionado no centro e três painéis instalados cada um nas outras três paredes da galeria. Nesses três painéis vemos alguns papéis que são entregues por esses pedintes nos ônibus como um resumo das histórias que são contadas, e que a artista chama objetos performáticos.

Ainda nesses painéis vemos fones de ouvidos dispostos abaixo de cada um desses objetos performáticos e que contém o áudio de conversas que a artista realizou com os respectivos pedintes, narrando de uma maneira muito mais aprofundada essas histórias que já fazem parte de um imaginário local. Tomada por todas essas histórias, a artista cria seu próprio conto performático, posto em prática por um ator nos coletivos da cidade. O dinheiro arrecadado 
por esse performer pedinte integra a exposição como objeto de referência dentro do pote de vidro mencionado. Um dado interessante é que ao longo da exposição esse pote foi recebendo dinheiro dos visitantes, uma ação não prevista pela artista, que doou o valor arrecado aos seus objetos de pesquisa, os pedintes.

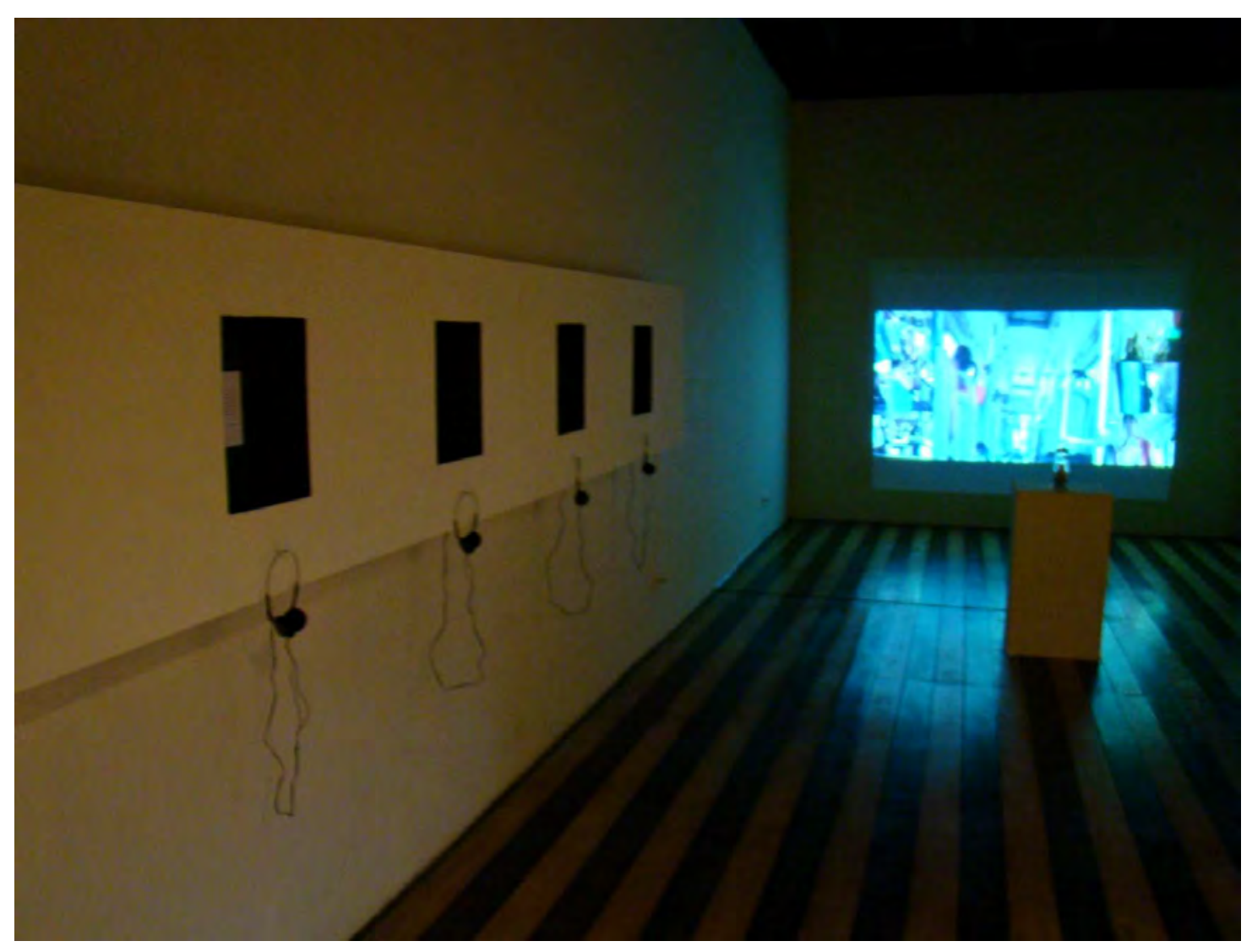

Ilustração 44: Registro da obra Performações Urbanas (2009) durante exposição homônima no Laboratório das Artes do Museu Casa das Onze Janelas em Belém-PA no ano de 2009.

Fonte: Acervo do projeto de pesquisa "Acervo de Videoarte paraense: sistematização e análise crítica" (CNPq/SEC/MinC - 2014-2016).

Foto: Carol Abreu

O vídeo projetado em uma das paredes apresenta um registro da ação realizada a partir do conto criado por Evanovitch e performado pelo ator, configurando-se por uma exibição em splitscreen, onde uma multiplicidade de imagens em tempos diferentes é apresentada no mesmo quadro a imagem projetada, uma narrativa fragmentada que constrói uma unidade de significado do vídeo enquanto propiciador de diferentes ângulos de um contexto social local. A experiência acontece entre a atenção concentrada do áudio, que ganha importância fundamental, e uma certa dispersão no que concerne à projeção, que apresenta esse quadro fragmentado. Percorremos o espaço entre os objetos performáticos, olhamos para a tela, nos 
direcionamos a outro áudio e assim por diante, ou mesmo assistimos o vídeo integralmente, ouvimos cada áudio em um percurso linear, as possibilidades de fruição do trabalho são diversas e esse mapa construído no caminhar é uma escolha do espectador.

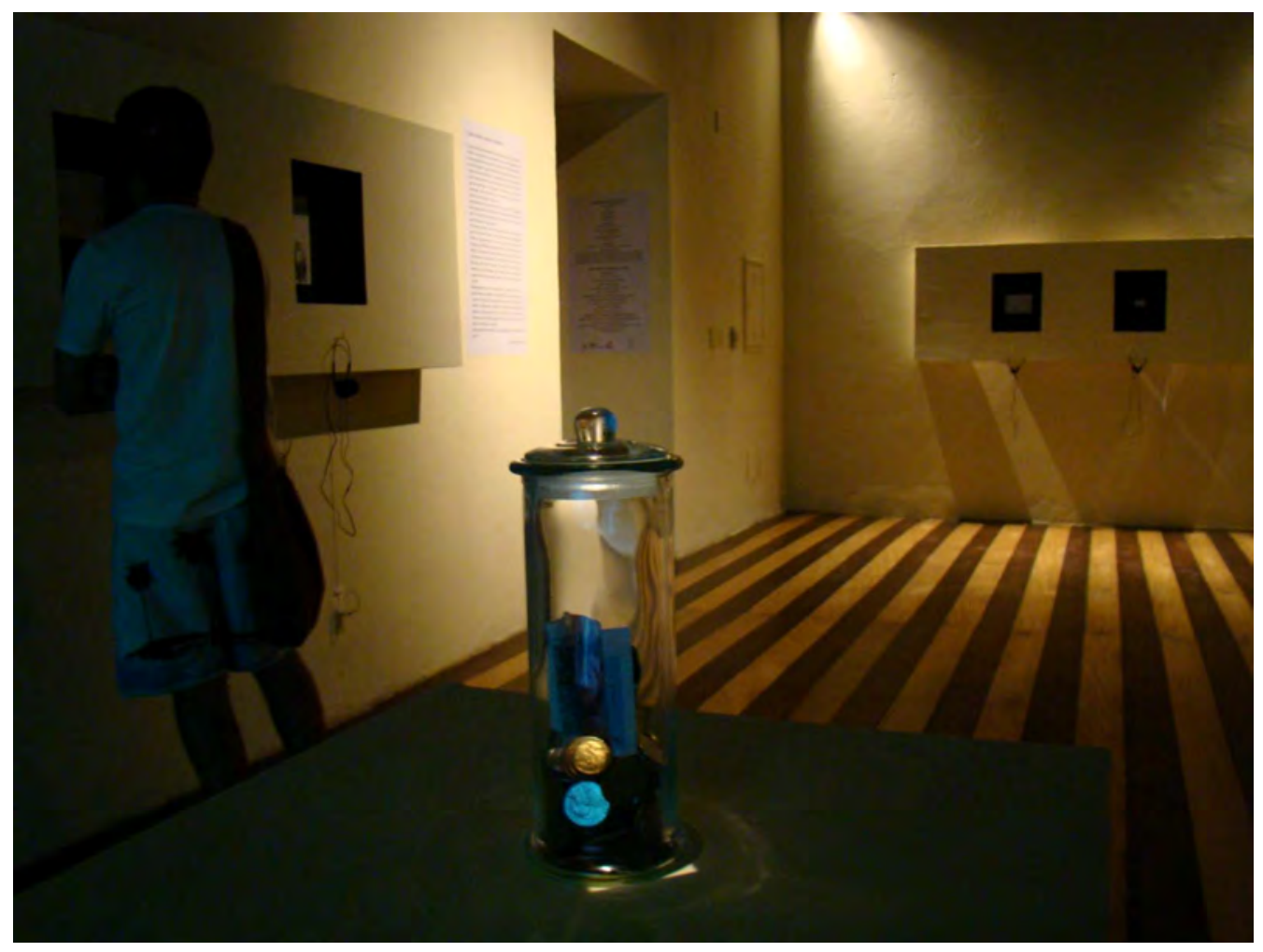

Ilustração 45: Registro da obra Performações Urbanas (2009) durante exposição homônima no Laboratório das Artes do Museu Casa das Onze Janelas em Belém-PA no ano de 2009.

Fonte: Acervo do projeto de pesquisa "Acervo de Videoarte paraense: sistematização e análise crítica” (CNPq/SEC/MinC - 2014-2016).

Foto: Carol Abreu

Na relação entre essas três abordagens materializadas pelos trabalhos o arranjo dos componentes funda também temporalidades diferentes. Em Patterns (2015) cada monitor requer uma atenção direcionada pelo isolamento do áudio que dialoga com o todo. Em Crossing Points (2010) uma sobreposição surge pela multiplicação das telas e áudios simultâneos, enquanto que em Performações Urbanas (2009) a simultaneidade surge pelo jogo de janelas, mas também, assim como na obra de Camplin, uma dispersão do conteúdo por isolamentos surge na utilização dos fones de ouvido. Esse eixo de análise, o modo de espacialização que chamamos vídeo-cenário compreende, portanto, um dos principais métodos de edificação dessa situação de ambiente na ocupação total e unificadora de objetos diversos no espaço da galeria e que solicita do espectador essa caminhada para compreensão da abordagem artística proposta. 


\subsubsection{VÍDEO-DILATAÇÃO}

Por fim, o último modo de espacialização que identificamos no universo de trabalhos encontrados em nossa pesquisa se configura pela apropriação desse termo dilatação, como o processo de ampliação das relações espaciais do vídeo por meio das interferências possíveis realizadas em sua narrativa em um espaço delimitado de tempo e que conferem a ele outros significados, materializada por três situações:

1) Trabalhos em que falamos em uma dilatação, ampliação, em função da modificação em tempo real do vídeo e seus componentes, em que a características visuais e sonoras da imagem são construídas pela ação do artista no próprio momento de exibição, associados a performances audiovisuais.

2) A existência de uma interferência simbólica no quadro do vídeo pela presença temporalmente passageira do corpo do espectador. A dilatação como no item anterior acontece em um espaço de tempo determinado que modifica a imagem do vídeo, com a diferença de que, enquanto no primeiro item a imagem de vídeo deixa de existir no espaço naquele formato de apresentação junto com o fim da duração da performance, aqui essa imagem permanece instalada em um espaço físico e sujeita a outras modificações simbólicas pelo público.

3) A instituição de uma certa distância temporal e espacial entre dois pontos: primeiro, o trabalho que está no espaço físico da galeria e segundo, informações que advém de fora desse lugar, espacial ou temporalmente falando, para serem agregadas ou modificarem o trabalho em algum aspecto.

Dessa maneira queremos apontar a partir daqui para uma direção referente a como aspectos de temporalidade também atravessam essencialmente a produção de videoarte, e essa é obviamente uma característica da natureza das próprias imagens em movimento. Como podemos ver nos três itens elencados acima a questão da duração dos trabalhos é uma das variáveis que permite a fundação desse modo de espacialização. Embora não tenhamos nos atido aqui a discussões referentes ao tempo, por se constituir por um universo também muito complexo de teorizações e apresentações em obras de videoarte, o levantamento, mesmo que atravessador, dessa questão é importante, já que falamos desde o início de obras em que a experiência também é fundada por temporalidades distintas. 
Ao que problematizamos como uma simultaneidade espacial, por exemplo, Timothy Barker (2012) indicará como apresentação de uma multi-temporalidade, formada também por camadas de tempo diferenciados e simultâneos que surge principalmente nos processos de interação com a linguagem digital e inevitavelmente a partir daqueles cinco princípios elencados por Lev Manovich. Barker levanta ainda a questão da categoria "processo" como fundamental para a compreensão de obras no contexto digital.

Em sentido mais amplo o autor fala do processo como a própria existência dos objetos que estão no mundo, se apropriando dos estudos de Alfred Whitehead e Gilles Deleuze para pensar esses objetos como temporalidade, na medida em que são a todo momento intercalados por sua história e apresentação no presente, um vir a ser, o mundo se refazendo a si mesmo a cada instância de tempo que passa. Essa situação é para o autor ampliada pelos meios digitais, na medida em que existem por um movimento de interatividade com o ser humano em uma situação que o atualiza o tempo inteiro pelas modificações que são por eles realizadas no âmbito do vídeo, da televisão e do computador, por exemplo. Veremos aqui que essa questão dos objetos como dotados de uma temporalidade configura o espaço como também em constante processo, por exemplo, nas ações de performance audiovisual ou interferências que o público realiza em alguns dos trabalhos apresentados, uma modificação que existe no tempo de experiência com a obra. Essa situação não é, no entanto, exclusiva desse modo de espacialização, e se pensarmos de modo mais amplo, como propõe Barker, desde os trabalhos daquele modo de espacialização que chamamos vídeo-espaço essa relação entre simultaneidade de espaço e atualização do tempo existe.

Os trabalhos que serão elencadas nesse tópico realizam uma ação de potencialização dessas características por assumirem em sua poética as possibilidades de atualização em tempo real que o digital permite, principalmente por meio da utilização de softwares computacionais e da internet, e desembocam inevitavelmente nessa expansão da relação com o espaço que viemos problematizando. Para Barker essa atualização do presente no âmbito do digital é apontada como uma retroalimentação, e o computador para o autor é a ferramenta tecnológica contemporânea que melhor materializa essa relação na sua natureza de armazenamento e geração autônoma de informações. Para melhor esclarecermos essas relações vamos a partir de agora apresentar algumas obras.

Naquele primeiro tópico de discussão elencado acima o trabalho $\mathbf{A}$ mulher e seu marido bife (2001) de Luiz Duva ${ }^{25}$ é exemplar. A obra é uma performance audiovisual em um

25 "Artista experimental no campo da videoarte, performance e novas mídias. Desenvolve desde o início dos anos 1990 narrativas pessoais em vídeo, bem como uma série de experiências com videoinstalações. De 2000 
ambiente escuro composto pelos seguintes elementos: a sala escura e um palco em que se encontram instaladas três grandes telas uma ao lado da outra com a do meio recuada. Nesse ambiente três agentes serão responsáveis pelo desenvolvimento da performance: o VJ Luiz Duva, a atriz Fabiana Prado (Fafi) E O Dj Julião, além do público presente que interage com a obra principalmente por meio da dança.

A performance consiste basicamente na apresentação ao vivo de elementos em três instâncias: as imagens modificadas pelo VJ, a música ao vivo do DJ, e a performance da atriz. As imagens que vemos nos vídeos são da atriz realizando ações com um pedaço cru de carne vermelha, andando com ele em ambientes diversos, jogando na parede, acariciando, amassando. Ao longo da duração do trabalho o que vemos é Duva modificar em tempo real essas imagens pré-gravadas da atriz por meio de softwares computacionais que permitem a inserção, no mesmo momento de exibição, de sobreimpressões, filtros de cor, rotações da imagem, entre outros. As alterações de Duva se apresentam como uma espécie de discussão a respeito do tempo dessas ações que a atriz realiza, onde o artista avança e recua no tempo do vídeo várias vezes, o que faz com que os movimentos da atriz na sua relação com esse pedaço de carne existam entre uma proximidade e distanciamento.

Ao mesmo tempo em que essas manipulações visuais são realizadas, a atriz se encontra sentada em uma mesa localizada em frente a uma das telas com um prato em que vemos um pedaço de bife, já não cru, à sua frente. A atriz realiza um tipo de embate psicológico com esse pedaço de carne, assim como nas imagens pré-gravadas, tocando-o, acariciando-o e deslizandoo sobre seu corpo para depois começar a comê-lo com expressões de quase êxtase. A ação como um todo é composta também pela execução ao vivo de música eletrônica pelo DJ Julião, que existe em um jogo entre a manipulação de imagem e som, um interferindo no outro de maneira dialógica e não hierárquica. Todos esses elementos convergem para uma discussão dessa relação da mulher com seu marido bife, um embate entre carnes, na submissão e dominância dos corpos, dos envolvimentos amorosos, da separação, cruzamento de consciências e do apagamento de um pelo outro.

O ambiente é imbuído, pela mixagem sonora e visual principalmente, de uma atmosfera de festa, um lugar para dançar. Em trabalhos dessa natureza um importante deslocamento espacial acontece na medida em que a fruição do conteúdo audiovisual acontece

para cá, vem se dedicando ao live images, termo por ele utilizado para designar a manipulação de imagens e sons em tempo real em ambientes imersivos, 'criação e apresentação de composições audiovisuais, a projetos de live cinema e ao desenvolvimento de conteúdo para diferentes mídias: TV, internet e celular. É um dos criadores e o diretor artístico da Mostra Live Cinema, exibição de performances audiovisuais, que acontece anualmente no Brasil desde 2007" Fonte: www.videobrasil.org.br. 
majoritariamente por meio de percepções periféricas, já que se tratam de ambientes em que atenções não são direcionadas a apenas um ponto. O processo de compreensão do espaço começa, portanto, a partir de meu corpo no espaço e passa pelo reconhecimento dos efeitos externos sobre meu corpo e de como posso devolver esses efeitos. Segundo Patrícia Moran (2004) o processo de montagem nessas experiências se dá por um passar entre imagens, num sentido físico do acontecimento, entremeado por corpos, luzes, cores. A autora fala de uma imagem-luz que penetra os sentidos dos presentes e convida-os à experiência do libertar-se no espaço para experimentar as escolhas, montagens, que o VJ direciona ao ambiente.

Esse não direcionamento da experiência a um único ponto aparece também em trabalhos como Permanência (2007), de autoria de Valzeli Sampaio e Mariano Klautau Fiho. No vídeo vemos a inserção de uma imagem que poderíamos classificar como fractal, onde as partes contêm o todo. André Parente (2008) descreve a imagem fractal como aquela que "(...) se apresenta como uma dimensão intermediária capaz de nos fazer transitar entre o contínuo e o descontínuo, a ordem e a desordem, o local e o global, a parte e o todo, o campo e o contracampo" (PARENTE, 2008, p. 43). A dimensão fractal da imagem reordena a linearidade da narrativa, esta não é mais essencialmente início e fim, por que o começo é fim e se integra ao início de modo a se tornar um só. A atitude da inserção no trabalho de imagens minimalistas em loop descondiciona a espera por uma imagem posterior, pois o que vem no futuro é o passado e a fruição presente é a integração entre dois tempos.

A instalação é constituída por duas projeções desse vídeo em paredes frente a frente com imagens de um balanço vazio em movimento em um quintal, entre as duas projeções o balanço objeto da gravação é instalado a partir de uma estrutura no teto da galeria, e atrás do balanço um canhão de luz é colocado de modo que projete na parede da frente a sombra de quem se sentar no balanço. A proposta é de compartilhamento de experiências sensórias pessoais para repercuti-las em âmbito macro. "Essa é uma instalação que não é completa, ela não serve para contemplação. Ela só é completa quando alguém está sentado no balanço, é mesmo algo para ser usado"26, argumenta Val Sampaio.

O balanço é objeto midiatizante entre corpo sensível e o ambiente que o cerca, as projeções delimitam um espaço "fora" que é reconstituído neste espaço físico. Aqui Valzeli Sampaio em parceria com Marian Klautau Filho continua sua pesquisa a respeito do tempo construindo um espaço de ativação de lembranças, bucólico, que acompanhado por sons de vento e cantos de pássaros reconstitui uma experiência onírica desse espaço. O momento em

26 Depoimento retirado do Catálogo da $26^{\mathrm{a}}$ edição do Salão Arte Pará no ano de 2007. 
que o participador se coloca no balanço entre as duas imagens estabelece uma interferência visual nas projeções, a sombra do corpo é incorporada à narrativa e o objeto poético já não é mais simplesmente o balanço, mas o movimento que o participador incita a partir de sua intervenção. A sombra do corpo que interfere na projeção é como uma substituição, preenchimento da ausência de um corpo no balanço que se movimenta no vídeo.

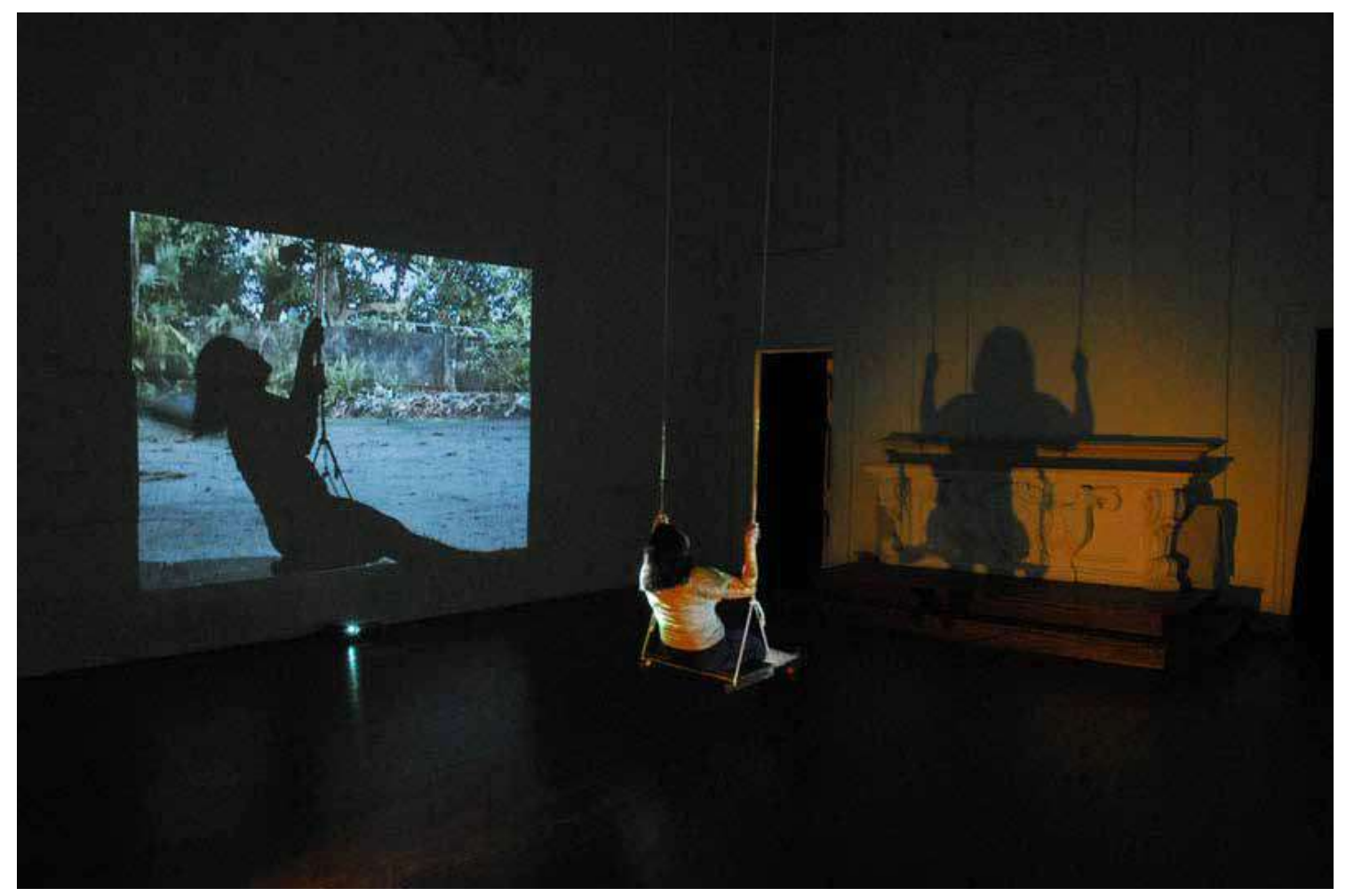

Ilustração 46: Registro da obra Permanência (2007) de Valzeli Sampaio e Mariano Klautau Filho na capela desativada do Museu Histórico do Estado do Pará durante o 26 Salão Arte Pará em Belém -PA no ano de 2007.

Fonte: Acervo do projeto de pesquisa "Acervo de Videoarte paraense: sistematização e análise crítica"

(CNPq/SEC/MinC - 2014-2016).

Foto: Mariano Klautau Fiho

A experiência de modificação da imagem é aqui, assim como no trabalho de Luiz Duva, existente em um período determinado de tempo, uma duração, com a diferença de que ela não configura uma modificação real nas características técnicas do vídeo, é realizada simbolicamente pela presença do corpo do espectador que pela sombra acrescenta uma espécie de sobreposição entre essa extensão do seu corpo e a luminância da projeção. Outra diferença reside no fato de que enquanto na performance de Luiz Duva o processo de manipulação da imagem coincide com o tempo de instalação, existência do vídeo no espaço, em Permanência (2007) a imagem mantém sua presença no espaço por um tempo muito maior, o tempo inteiro 
da exposição, existindo na galeria independente da presença ou não do corpo que a transforma. Aqui indicamos, portanto, como esse tipo de interferência na projeção pode sim caracterizar uma ação poética, ao contrário do que foi apontado por Liz Kotz (2008).

Essa solicitação de uma participação do espectador que vai para além do caminhar nesses espaços também aparece em Caixa de Pandora (2006) realizada pelo grupo homônimo de artistas formado nessa época por Cláudia Leão ${ }^{27}$, Mariano Klautau Filho e Orlando Maneschy. O espaço expositivo era composto por pequenas fotografias produzidas pelos três artistas dispostas de maneira irregular nas paredes da galeria e uma grande lâmina de vidro proposta por Cláudia Leão, onde um vídeo de Orlando Maneschy era projetado. Nesse vídeo Maneschy apresenta imagens que muito se assemelham novamente aquela característica de descontextualização de certos objetos gravados, em que uma série de pontos de luz, dos postes que estão no caminho do artista, ganham também um desfoque e se apresentam essencialmente como luz, cor e forma. A projeção desse vídeo é direcionada para um dos cantos da galeria, o que institui o fator de deformação do retângulo da projeção. Nesse sentido, é a arquitetura do espaço que permite uma nova configuração dessa apresentação para além do formato tradicional

$\mathrm{Na}$ outra extremidade da galeria, vemos uma mesa com um pequeno gravador e cadernos com poemas de Mário Faustino, que deveriam ser lidos e gravados pelo espectador, uma proposta de "performance para o público", segundo denominação de Mariano Klautau Filho. Esse é um dos dados mais interessantes que a configuração do trabalho Caixa de Pandora traz consigo, a possibilidade inerente de ativação de uma participação do público em outra instância, que se torna elemento fundamental para a construção e completude da finalidade poética deste trabalho, possibilitando o lançamento de hipóteses para pensar o possível aparecimento de uma situação performática desses agentes participadores nesses ambientes. No entanto, devemos levar em consideração, que ao levantarmos essa discussão não estamos definindo este participador como de fato um performer, mas propiciando mecanismos de entendimento de como este dispositivo instalativo contribui para a inserção deste espectador como construtor de outros sentidos.

Falamos então de uma dilatação do espaço em que o vídeo está instalado pela referência a uma presença que esteve ali e que agora está fora, em outro tempo e espaço. Os áudios dos

27 "Vive e trabalha em Belém (PA). Pesquisadora e artista visual, é doutora em Comunicação e Semiótica pela PUC-SP. Tem experiência na área de artes, com ênfase em fotografia nos temas: ontogênese da imagem, memória, esquecimento, saudade, esquizofrenia e artes visuais. Como artista, participou do Rumos da Nova Arte Brasileira - Entre o mundo e o sujeito - Rumos Artes Visuais; Visões e alumbramentos, Coleção Joaquim Paiva; Mostra Parlela - 25 a Bienal de São Paulo; Amazônia, a arte e Prêmio Diário Contemporâneo de Fotografia." Fonte: www.kamarakogaleria.com.br 
poemas configuram um rastro da ação do público, e na medida em que se acumulam e são ouvidos direcionam também diferentes leituras daquele ambiente, o que inclui a atenção dada ao vídeo. Esse novo conteúdo é agregado pelo público a partir de uma base de dados (os poemas) oferecida pelos artistas. O que queremos apontar a partir daqui é como algumas propostas se fundamentam nessa relação entre o que está na galeria, na presença do público, e ações que aconteceram em temporalidades ou espacialidades anteriores e se configuram em dado momento como elemento integrante do trabalho instalativo.

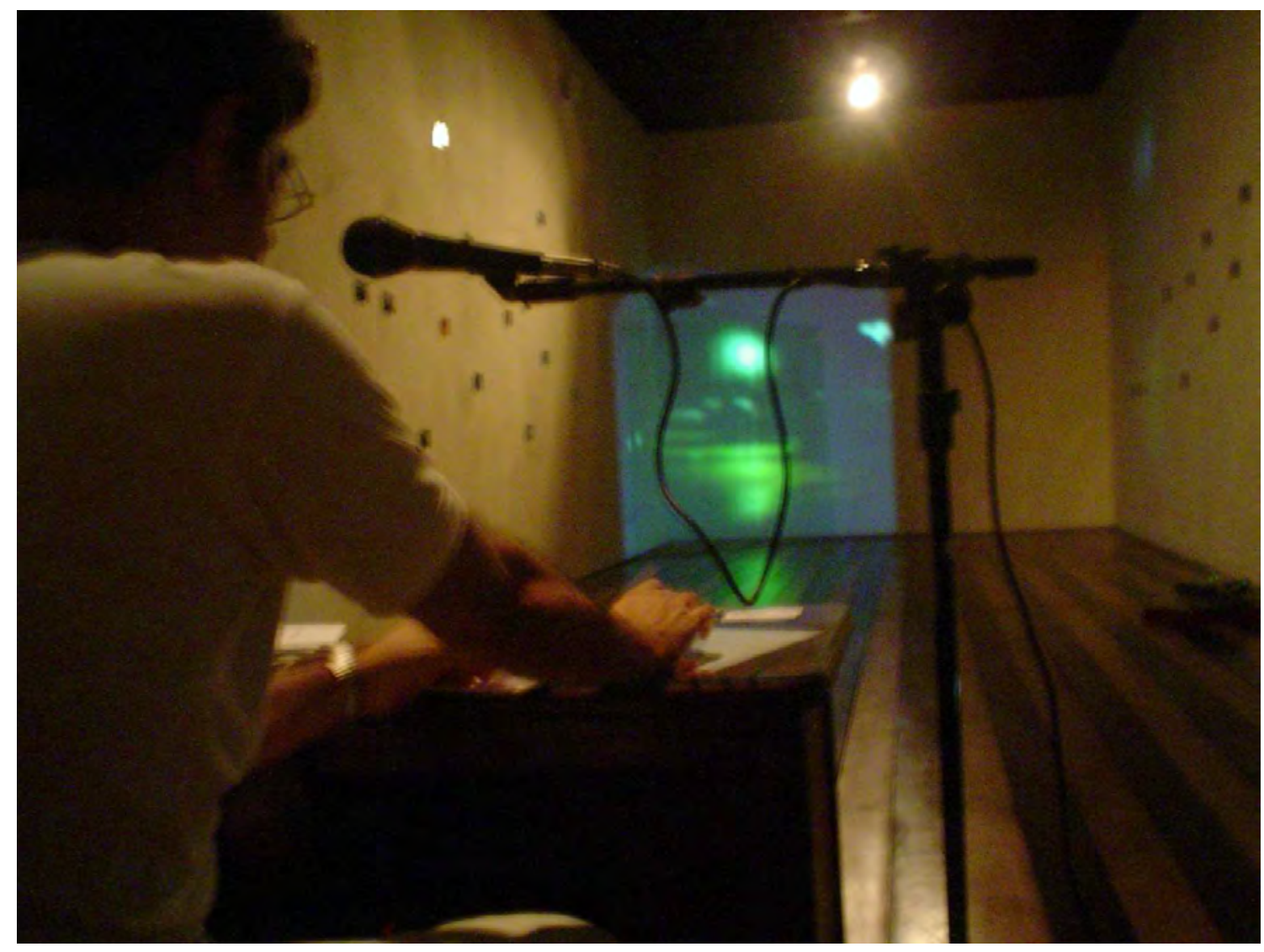

Ilustração 47: Registro da obra Caixa de Pandora (2006) do grupo homônimo, formado nessa ocasião por Cláudia Leão Mariano Klautau Filho e Orlando Maneschy, durante exposição pelo Projeto Coletivos no Laboratório das Artes do Museu Casa das Onze Janelas em Belém - PA no ano de 2006.

Fonte: Acervo do projeto de pesquisa "Acervo de Videoarte paraense: sistematização e análise crítica" (CNPq/SEC/MinC - 2014-2016).

Foto: Valzeli Sampaio.

Essas questões são levantadas, por exemplo, em Mangueiras de Belém (2011) de Valzeli Sampaio. Nesse trabalho a artista realizou uma ação de intervenção urbana demarcando as mangueiras da cidade de Belém e criando o que para a artista se torna um mapa de visibilidade desses elementos no ambiente urbano. Em uma das intervenções um grupo de 
artistas acompanhou Sampaio e demarcou as mangueiras com $Q R \operatorname{Codes}^{28}$, recebendo dados como longitude e latitude que permitiam que essas árvores fossem localizadas por $G P S^{29}$ a partir de câmeras de celular. A ação se desdobra em um blog do projeto com a inserção dessas informações de localização e outras como os registros das ações e textos, que geram alguns mapas como referentes dessa deriva pela cidade, processo que a artista chama Postulano 01, 02 e 03, cada um deles referentes a uma ação específica de demarcação das mangueiras. A artista, no blog do projeto, convida ainda os habitantes da cidade a percorrer essas mangueiras, ativar os QRCodes e enviar vídeos para compor essa página.

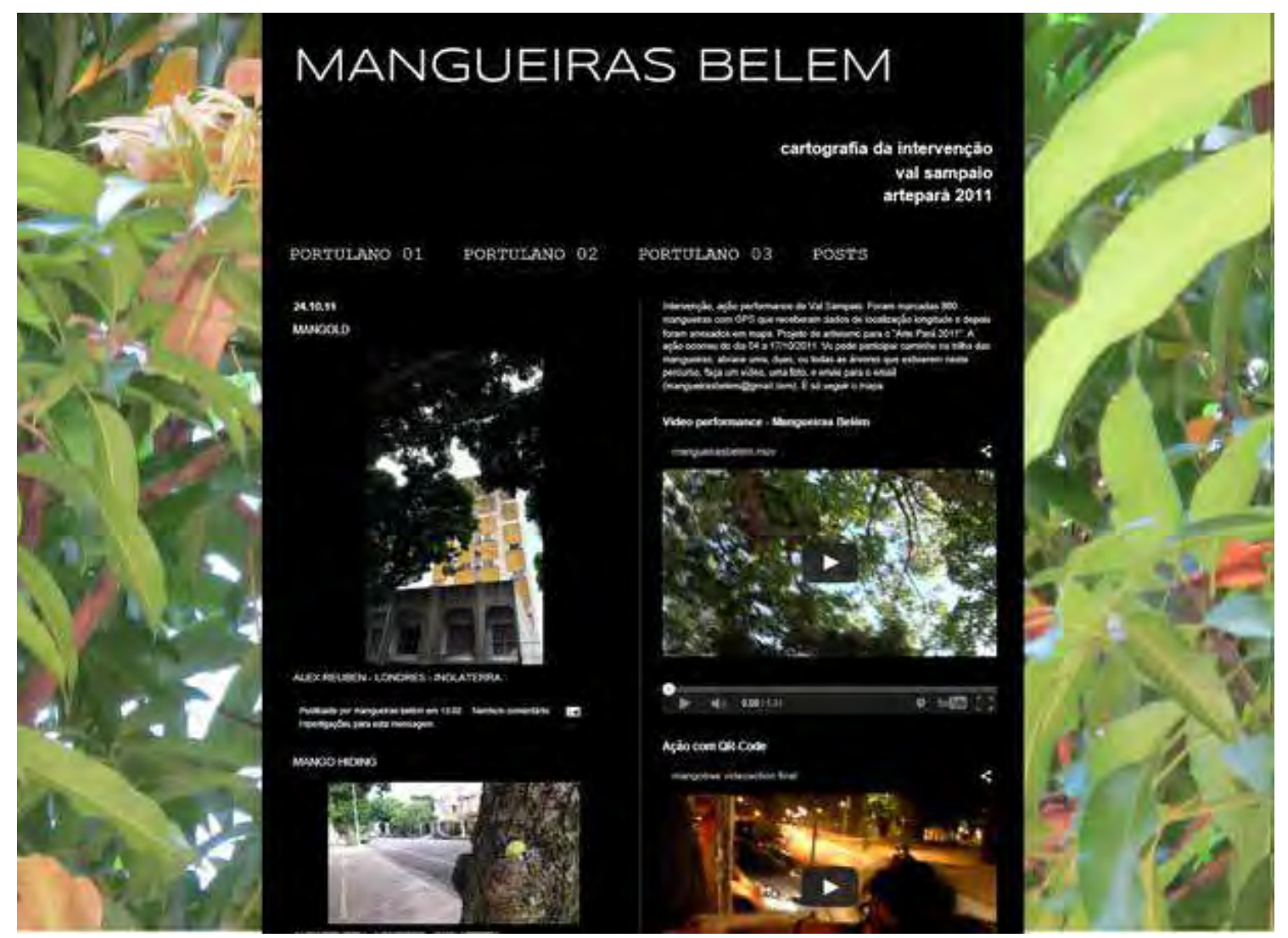

Ilustração 48: Interface do blog do projeto Mangueiras de Belém (2011) de Valzeli Sampaio Fonte: Acervo do projeto de pesquisa "Acervo de Videoarte paraense: sistematização e análise crítica" (CNPq/SEC/MinC - 2014-2016). Foto: Valzeli Sampaio

28 Sigla para Quick Response Codes, uma espécie de código de barras que gera respostas rápidas de direcionamento para outros lugares como websites, no caso do trabalho de Valzeli Sampaio o blog do projeto.

29 Sigla para Global positioning system, corresponde a um mecanismo de posicionamento e reconhecimento de lugares por meio de satélites que enviam dados de localização para algum aparelho receptor, como tablets e celulares. 


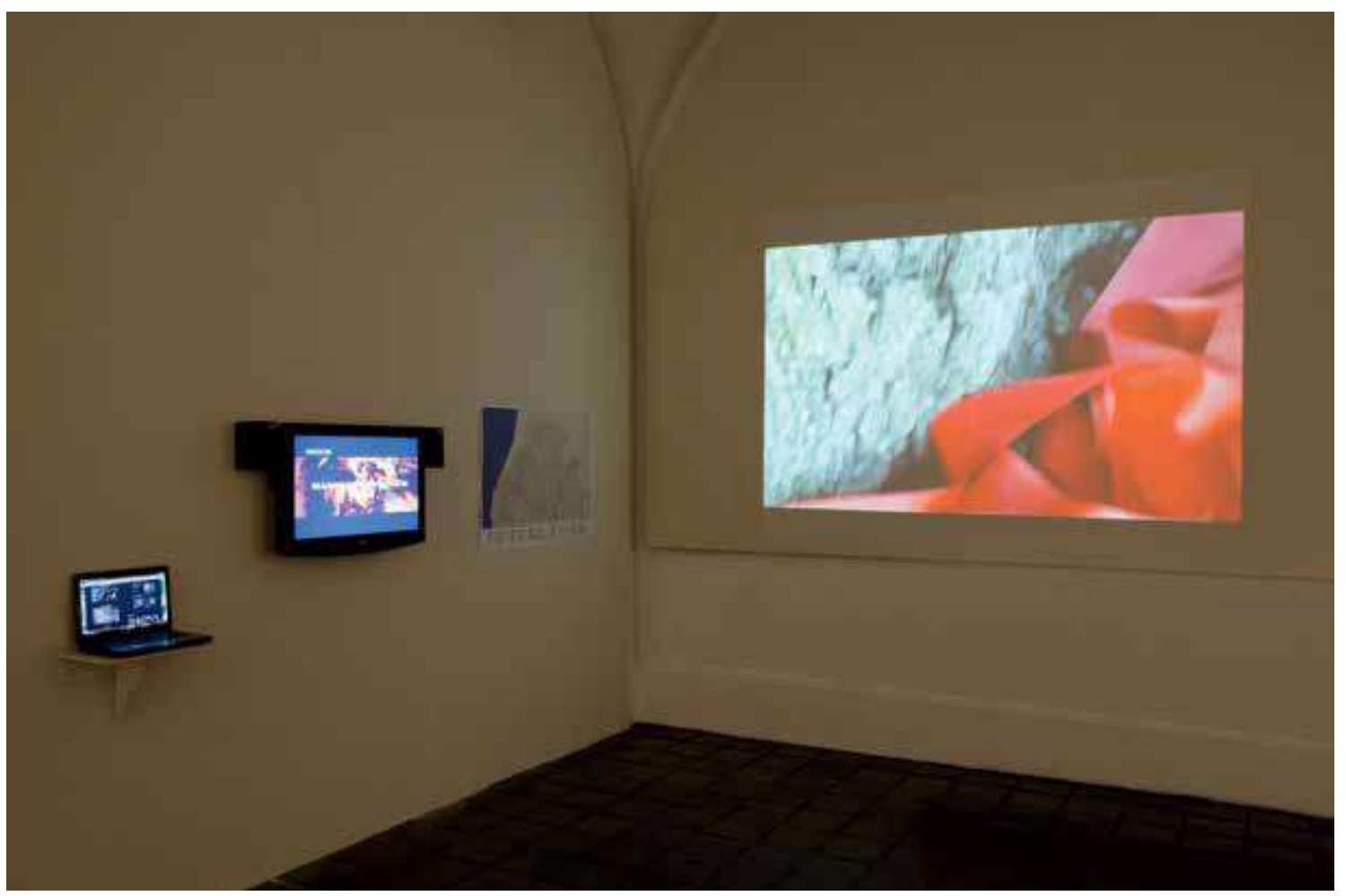

Ilustração 49: Registro da obra Mangueiras de Belém (2011) de Valzeli Sampaio no Museu Histórico do Estado do Pará durante o 30 Salão Arte Pará em Belém-PA no ano de 2011.

Fonte: Acervo do projeto de pesquisa "Acervo de Videoarte paraense: sistematização e análise crítica" (CNPq/SEC/MinC - 2014-2016).

Foto: Valzeli Sampaio

Ainda em 2011 Valzeli Sampaio apresenta uma versão do projeto para o espaço da galeria, composta por uma videoperformance projetada em uma parede, os registros em vídeo do processo de demarcação das mangueiras exibidos em um monitor, o mapa desse percurso plotado na parede e um computador com acesso ao blog Mangueiras de Belém ${ }^{30}$. $\mathrm{Na}$ videoperformance apenas as pernas e as mãos de Sampaio aparecem, segurando um amontoado de longas fitas vermelhas, cor da bandeira do estado do Pará que tem como capital a cidade de Belém, conhecida por ser a Cidade das Mangueiras. Nessa ação a artista caminha por entre mangueiras e em um dado momento envolve seu tronco com essas fitas, depositando-as por fim no espaço próximo a sua raiz. O conjunto dessas ações, entre performance, mapeamento e disponibilização disso interfere na convivência dessas árvores com a cidade e com quem deveria por elas zelar, confere ao transeunte um papel de agente de investigação desse lugar ao solicitar o envio de registros, insere o percurso em um desejo de historização, do lugar da memória da cidade.

30 www.mangueirasbelem.blogspot.com.br 
Essa incursão por uma possibilidade de agregação de conteúdos por parte do público não acontece necessariamente no momento em que esse agente está no espaço do trabalho na galeria, esse último aponta muito mais para um convite à saída daquele lugar na busca por essas árvores de certa maneira catalogadas pela artista. $\mathrm{O}$ próprio processo de interferência no conteúdo do trabalho prescinde do retorno do público à galeria, por acontecer no âmbito do envio de dados pela web.

Encontramos relação parecida também em Beneath and Beyond (2008) de Stephen Hurrel. No espaço da galeria o artista instala duas grandes projeções em uma parede e um total de seis caixas de som posicionadas à frente, cada uma com um foco próprio de iluminação. Para este trabalho Hurrel desenvolveu em parceria com Robert Farrell um software que, ligado a cem estações de monitoramento ao redor do mundo, capta as vibrações dos movimentos sísmicos do interior da terra a partir de movimentações de placas tectônicas ou erupções vulcânicas, por exemplo, que produzem ruídos inaudíveis ao ouvido humano (chamados pelo artista de Background sounds) e são a matéria-prima principal desse trabalho.

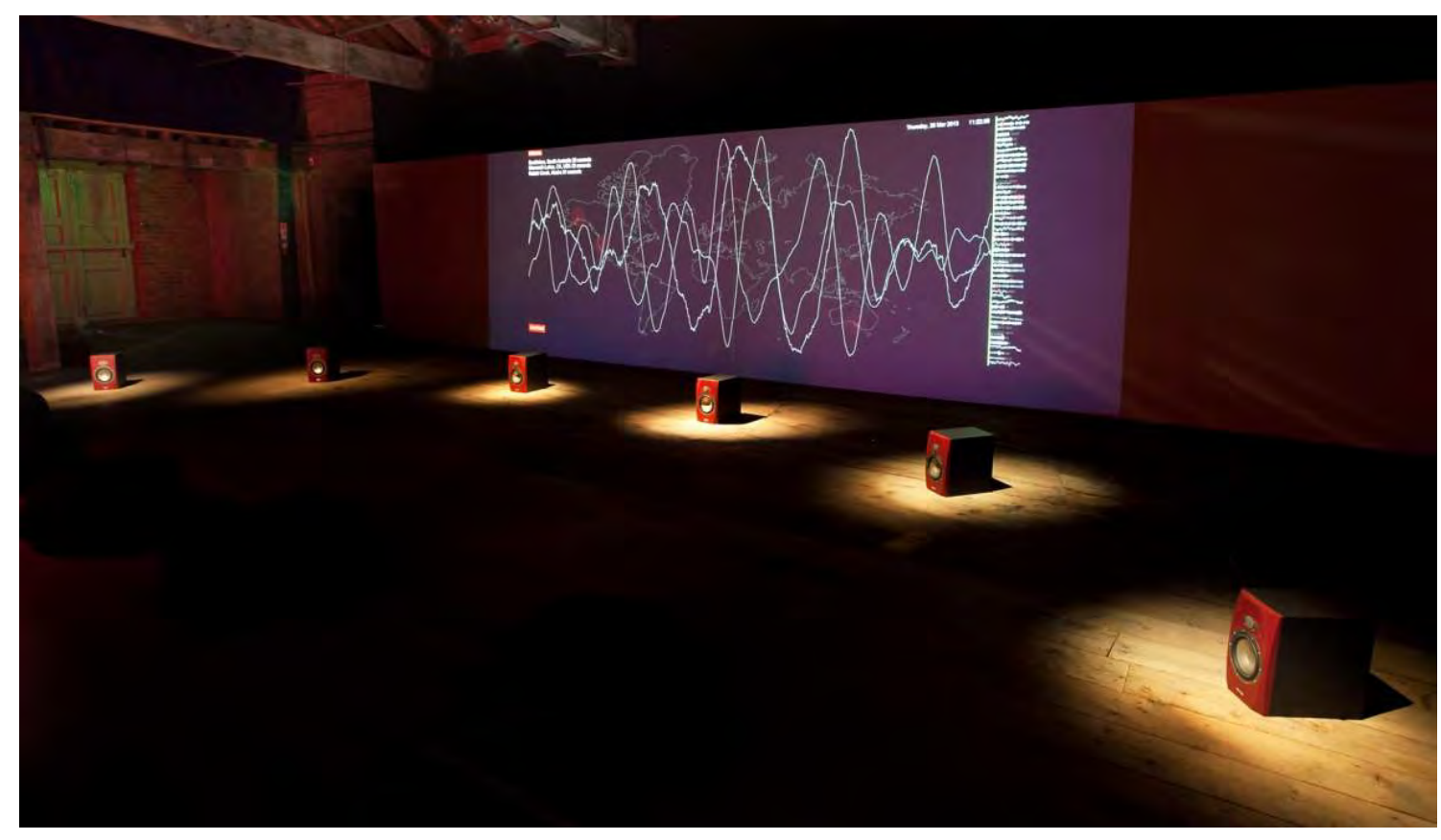

Ilustração 50: Registro da obra Beneath and Beyond (2008) de Stephen Hurrel durante exposição homônima na Tramway Gallery no ano de 2008 na cidade de Glasgow (Escócia)

Fonte: Acervo pessoal do artista

Foto: Stephen Hurrel

O software produzido se encarrega de captar esses sons e aumentar sua amplitude ao máximo, de modo que passem a ser escutados por nós. Esses sons agora audíveis (que o artista 
chama Event sounds) são transmitidos em tempo quase real do acontecimento via computador para as seis caixas de sons instaladas na galeria, considerado aqui o atraso de alguns minutos no recebimento desses Background sounds. Ao mesmo tempo o software codifica esses sons em ondas sonoras visuais que são projetadas ao fundo dessas caixas. Nessa projeção as ondas se entremeiam também à informação da hora e local de onde foram captados os sons escutados naquele momento. Outro dado importante é o fato de que mais de uma informação de movimentos sísmicos podem ser recebidas ao mesmo tempo, já que o computador e o software estão ligados a um total de cem estações ao redor do mundo, o que implica a sobreposição de sons e imagens das ondas sonoras advindas desses lugares diferentes.

Hurrel nessa obra volta a levantar as questões que perpassam a sua pesquisa da relação entre ser humano, tecnologia e ambiente natural, tornando o desenvolvimento dessa tecnologia de software e sua apresentação na galeria uma possibilidade de aproximação humana com camadas de certa maneira inatingíveis se não pela mediação tecnológica. O título do trabalho já indica essa relação e o artista em entrevista à organização Internet \& Digital Arts Media ${ }^{31}$ declara que o trabalho fala justamente do que acontece abaixo de nossos pés, no interior da terra, e do que está para além do nosso deslocamento imediato, já que as informações são obtidas a partir de pontos de movimentação localizados ao longo de todo o globo terrestre.

Hurrel insere, portanto, mais uma camada nessa perspectiva de dilatação. Ainda se utiliza das ações de modificação em tempo real de som e imagem e também na inclusão de informações diferentes ao longo do tempo da exposição. No entanto, diferente da performance de Luiz Duva em que o artista está presente nesse espaço e é a sua ação física direta quem sanciona as escolhas de modificação dessas imagens e sons, aqui nessa obra aquele princípio digital da automação apontado por Manovich é quem funda essas alterações a partir do software desenvolvido. Outro movimento reside no fato de que essas novas informações agregadas não surgem mais pela ação do público, e sim pela própria linguagem de programação da máquina, mantendo, no entanto, aquela característica de potencializar a referência a um espaço e tempo que estão fora da galeria, que vimos no trabalho de Valzeli Sampaio. Além disso o que entendemos por vídeo, som e imagem, prescindem de gravações prévias para sua existência no espaço, ele existe apenas no fluxo das informações enviadas, que de modo algum se repetirá em suas combinações, já que essas informações fogem do controle do artista.

Por fim queremos retomar aqui aquela situação de performance audiovisual para

31 "Fundada em 1998. (...) Seus recursos são direcionados principalmente para o incentivo ao desenvolvimento da produção de vídeo, apoiando projetos de novas mídias no campo da regeneração social de comunidades, patrimônio e história, artes, ciência e educação". Fonte: www.internetanddigital.com. 
demonstrar como algumas dessas relações apontadas por nós podem coexistir em um mesmo trabalho e, para isso, um caso exemplar para nós é o trabalho Corpo 4K (2014) de Almir Almas $^{32}$. Com duração de 20 minutos e apresentada em um teatro, a performance foi orientada por um roteiro dividido nos seguintes blocos: Parte I - Kumbara Grande; Parte II - Místicos e Profundos; Parte III - Sakura; Parte IV - Navalha; Parte V - Grima; Parte VI - "Quem jogou jogou ..."; Parte VII - Créditos. Cada um desses blocos rememora uma dada situação referente a determinada cultura vivenciada por Almir Almas em sua trajetória, entre práticas culturais orientais e afro-brasileiras. Compuseram a realização desse trabalho o VJ e diretor Almir Almas, a assistente de direção Bruna Vallim, o músico Roger Bacoom, Emilie Sugai performer de dança Butoh, Fábio Rocha (Soneca) capoeirista, Mestre Griot Alcides Lima, a equipe de rede do espaço, uma equipe de engenharia de compressão e digitalização em $4 \mathrm{~K}$ e uma equipe de integração técnica coordenada por Thiago Afonso de André.

Nesse trabalho, Almir Almas declara que como VJ aproxima sua experiência com a direção de televisão, em que a montagem e escolha de planos e quadros se dá no mesmo momento da transmissão, no jogo entre imagens pré-gravadas, captações ao vivo e improvisação. A performance é executada a partir dos seguintes elementos: inicialmente vemos uma projeção em grandes dimensões em uma tela, advinda de uma captação em ULTRAHDTV 4K em tempo real da performer Emilie Sugai, que está em uma sala separada cerca de 500 metros do teatro. Nesta sala, Sugai executa movimentos da dança Butoh orientada por marcações temporais do roteiro (ditadas pela assistente de direção Bruna Vallim) enquanto uma câmera $4 \mathrm{~K}$ capta suas imagens e as envia diretamente via Rede Fotônica de alta capacidade, de 1Gbps e Encoder/Decoder Fogo Sender/Receive 4K para o equipamento do diretor Almir Almas localizado no teatro na lateral do palco, o qual projeta também em qualidade $4 \mathrm{~K}$ o vídeo naquela tela de grandes proporções. Em cada lado da projeção, um monitor de televisão exibe imagens de banco de dados de Emilie na dança Butoh e a frente da grande projeção o performer capoeirista Fábio Rocha Soneca atua interage a partir da capoeira com os movimentos de dança Butoh proferidos por Emilie e visualizados nesse vídeo projetado. Ainda nesse espaço o músico Roger Bacoom executa músicas com sonoridades que retomam aquela hibridação entre a cultura oriental e afro-brasileira.

32 "Diretor audiovisual, professor e pesquisador, realiza trabalhos de videoarte, videopoemas, intervenções em mídias e é membro dos coletivos Formigueiroe C.o.b.a.i.a; Mestre e Doutor em Comunicação e Semiótica pela Pontifícia Universidade Católica de São Paulo, leciona no Curso Superior do Audiovisual e no Programa de Pós-graduação em Meios e Processos Audiovisuais da Escola de Comunicações e Artes da Universidade de São Paulo. Entre seus vídeos destacam-se Anatawa Ikaga Desuka/How are you?/Como vai? (2002), Reflexo Solar/Corpo presente (2001) e Copan Thriller (1988/1996).” Fonte: www.videobrasil.org.br. 


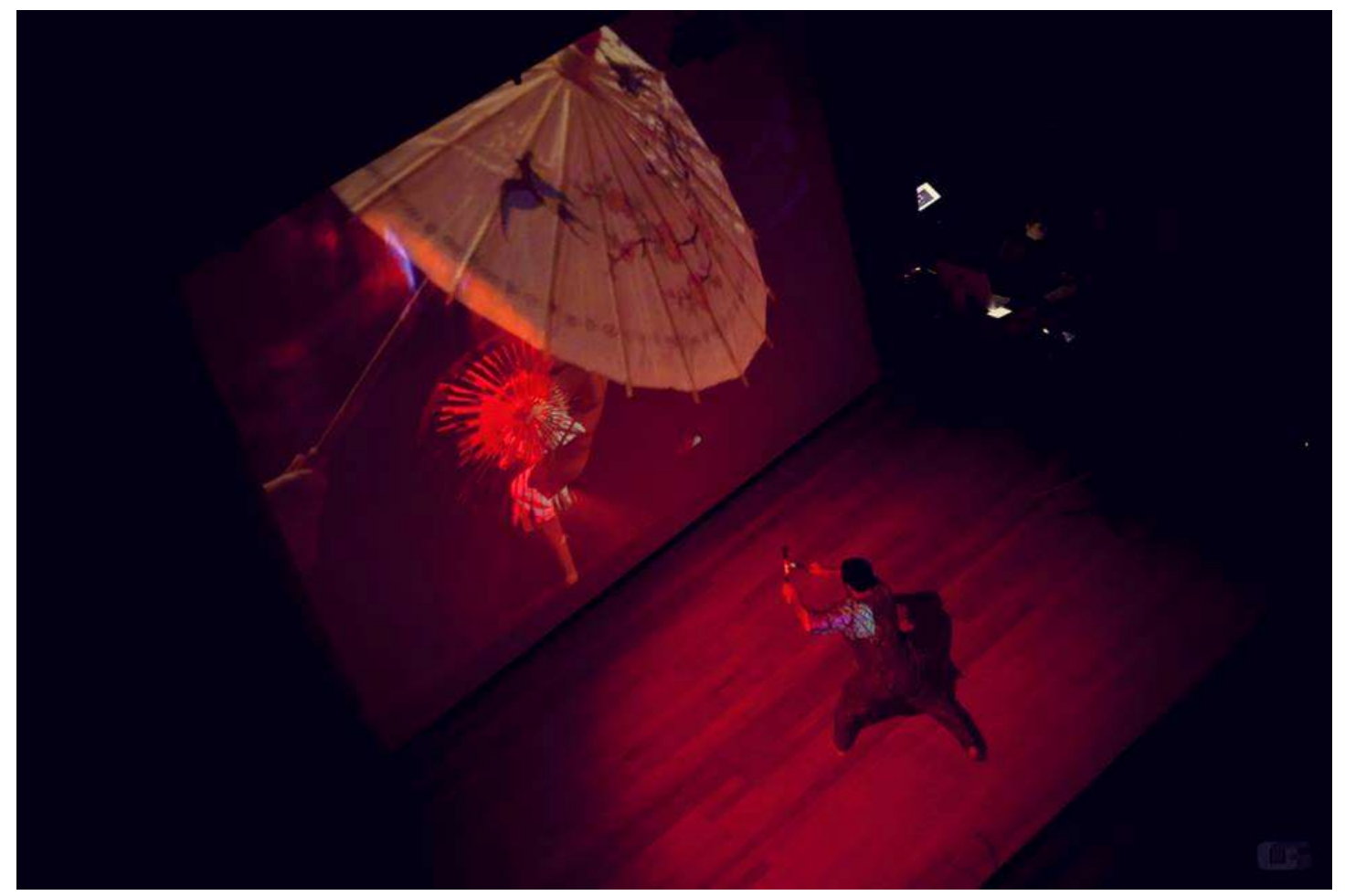

Ilustração 51: Registro da performance Audiovisual Corpo 4K (2014) dirigida por Almir Almas e realizada em 2014 no teatro da Faculdade de Medicina da Universidade de São Paulo durante o Congresso Internacional Cinegrid Brasil 2014

Fonte: Acervo pessoal do artista

Foto: Óskar Garcia

O clímax do trabalho acontece quando Fábio Rocha Soneca, o capoeirista, começa a tocar berimbau e o ritmo da sonoridade controlada por Roger Bacoom e dos movimentos realizados por Emilie também são influenciados e, portanto, acelerados. Esta situação perdura na performance até que um novo conjunto de banco de dados de vídeos de Emilie performando nas ruas de São Paulo sejam sobrepostos à transmissão ao vivo em janelas e sobreimpressões que também agregam a imagem do capoeirista gravada por outra câmera. A performance é finalizada com uma gravação sonora de Mestre Alcides que canta três vezes "Quem jogou, jogou, quem não jogou não joga mais”. Aqui vemos uma relação de mutualidade que se dá na montagem e exibição do trabalho, enquanto um agente modifica o outro durante as decisões técnicas, estéticas e políticas por seu caráter colaborativo, e o mesmo acontece durante a apresentação. Verificamos como, por exemplo, o trabalho de som de Roger Baccom influenciará o processo de mixagem de Almir Almas, ou os movimentos corporais de Emelie Sugai (Butoh) poderão conduzir a performance de Fábio Rocha Soneca (Capoeira). 


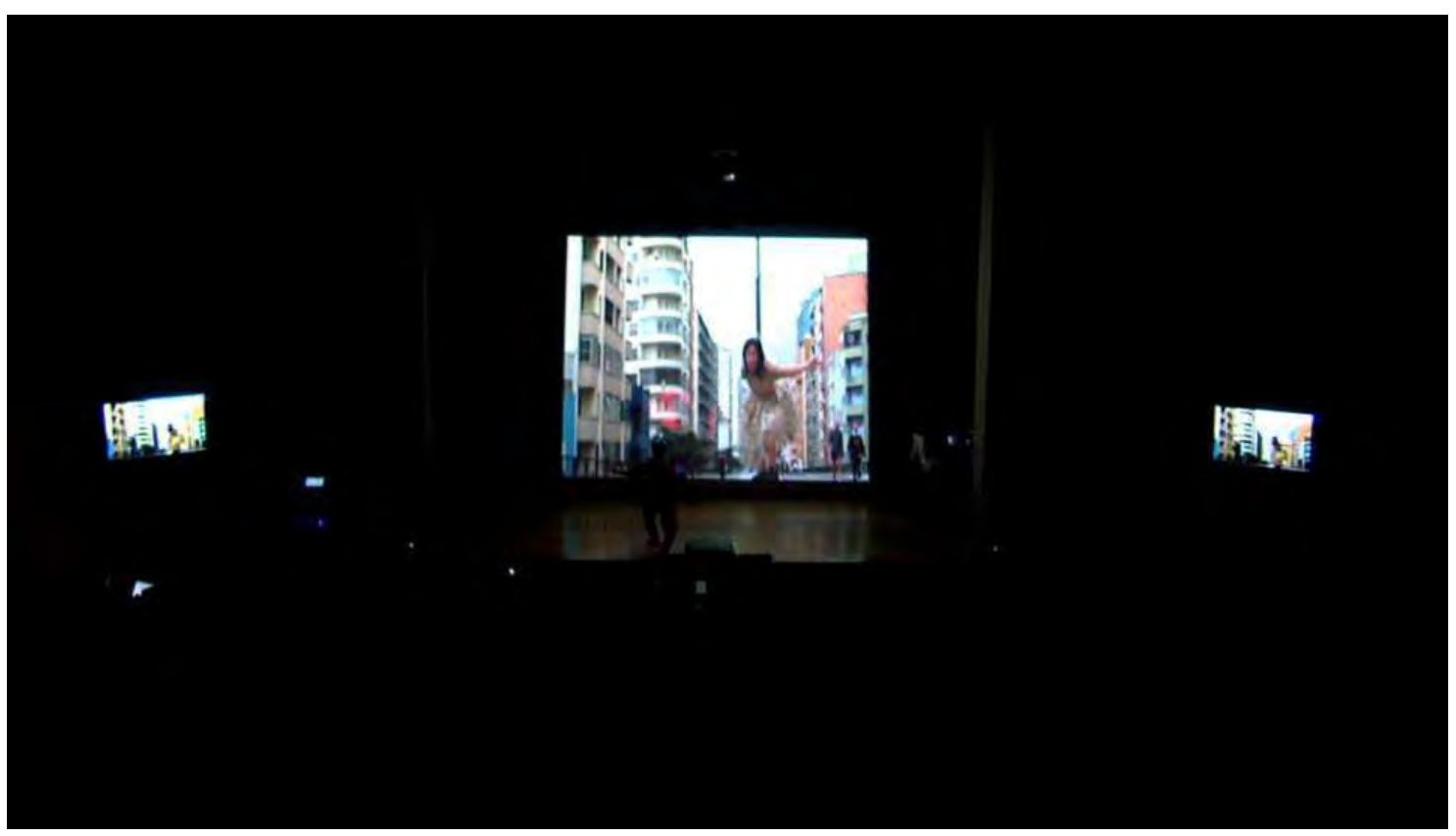

Ilustração 52: Registro da performance Audiovisual Corpo 4K (2014) dirigida por Almir Almas e realizada em 2014 no teatro da Faculdade de Medicina da Universidade de São Paulo durante o Congresso Internacional Cinegrid Brasil 2014

Fonte: Acervo pessoal do artista

Foto: Bruna Vallim

O primeiro aspecto espacial essencial a se considerar aqui é o fato de Emelie não estar presente no mesmo espaço físico que o diretor/VJ, o músico, e o performer capoeirista, diferente da proposta de Luiz Duva por exemplo. A interação entre Emelie e Fábio Soneca acontece virtualmente. Soneca interage respondendo à transmissão ao vivo de uma performer que sequer o vê naquele momento, reagindo àqueles movimentos a partir de seu repertório corporal, de modo a tentar estabelecer um diálogo entre os movimentos da capoeira e os aspectos de movimento da dança Butoh.

O segundo ponto importante, e que pensamos influenciar diretamente as questões espaciais que perpassam o trabalho, é justamente a alta resolução da imagem projetada em grandes dimensões. Para quem assiste a performance, o vídeo em transmissão ULTRAHDTV $4 \mathrm{~K}$ em uma sala escura traz uma relação clara de fantasmagoria, como uma tentativa do próprio vídeo de incluir o corpo de Emilie naquele espaço da maneira mais realista possível a partir da alta resolução. O momento de projeção instaura a dúvida da presença real ou virtual do corpo de Emilie naquele espaço, dúvida essa que só é sanada no momento em que a performer se aproxima da câmera e torna-se um corpo gigantesco, atribuindo ainda mais estranheza e um certo teor de medo ao espetáculo.

Em Corpo 4K, a relação entre artistas e audiência parece ainda preconizar um certo 
distanciamento das reações da última, talvez em função do lugar em que foi apresentado, um teatro de formato tradicional. A audiência nesse lugar se coloca nas cadeiras e assiste a performance como em um espetáculo de teatro, o que não significa que a experiência de fruição não aconteça. A interferência da reação da audiência nos processos criativos dos artistas é, no entanto, minimizada, já que não são externalizadas reações físicas claramente visíveis ao ponto de VJ, músico, ou performers modificarem suas ações de maneira mais incisiva por esse viés de relação.

Almas retoma e unifica aqui uma série dessas características de espacialização do vídeo de que vínhamos falando nos trabalhos ao longo desse texto, como a projeção em grandes dimensões e a multiplicação da imagem dentro do quadro da projeção ou por meio da inserção de monitores. O vídeo se dilata, portanto para outra espacialidade que não é apenas a da relação de sua presença no lugar em que está instalado e se funda principalmente nessa noção de deslocalização proporcionada pelo cruzamento entre o espaço em que a performance acontece na presença do público, e parte dela que acontece em outro espaço e só pode ser visualizada, nesse caso, por meio do vídeo em transmissão em tempo real. Esse trabalho reúne, portanto, a primeira e a terceira abordagem que apontamos no início desse tópico, e se difere da segunda abordagem pelo fato da imagem do vídeo só existir na duração da performance, assim como na obra A mulher e seu marido Bife (2001).

Em resumo, quando falamos nessa vídeo-dilatação nos referimos a trabalhos em que o vídeo é modificado em tempo real, técnica ou simbolicamente falando, seja pela presença das ações de um corpo no espaço (artista ou público) ou por informações que são advindas de lugares fora da galeria e agregadas ao trabalho em seu período de exposição/exibição. Os elementos que unificam essas abordagens são, por fim, o fato de que essas modificações existem em uma duração específica, e de que as próximas modificações que possam vir a surgir nunca serão iguais àquelas já realizadas. 


\section{CONSIDERAÇÕES FINAIS}

Ao longo deste trabalho levantamos algumas discussões sobre a relação de instauração do vídeo no espaço físico, elencando como isso se desenvolve por meio de modos de espacialização que serviram como eixos de análise de recorrências comuns a alguns trabalhos de videoarte que entramos em contato durante esse percurso de pesquisa, no esforço também de procurar na relação com outras mídias como a televisão, o cinema e o computador bases para o pensamento da natureza de problematização espacial da videoarte. A partir dessas abordagens propomos pensar que uma possível especificidade contemporânea da videoarte ainda reside na desestruturação da lógica representativa bidimensional do quadro em seus segmentos de espacialidade e que se estende para o espaço físico, como já apontado pelos autores que atravessam nosso texto.

Esse processo de espacialização na linguagem do vídeo vai de uma mixagem de imagens a partir da dissolução dos planos contínuos e atribuição de escolhas de simultaneidade, se desenvolve em construções ambientais e desemboca em um arranjo que já não é feito apenas pelas escolhas dos artistas em um resultado final fechado, apontando para a possibilidade de alteração do conteúdo a partir da interação com o fruidor, processo que acreditamos encontrar um lugar para desenvolvimento nos espaços de museus e galerias. Em diálogo com Arlindo Machado, pensamos a videoarte em seus formatos para a galeria como uma ação de resistência a um estado parasitário do vídeo na relação com as outras mídias. Para nós, foi esse um dos contextos em que a vídeoarte encontrou potencialidades para apresentar propostas com características que a imbuíram de uma discussão acerca de sua própria linguagem, que a pode diferir de outras como o cinema e a televisão. Essa diferença é, no entanto, construída a partir de certos acoplamentos e convergências plásticas com essas outras linguagens citadas.

Obviamente não nos atrevemos a limitar a prática da videoarte a um essencialismo que se restringe a essas características que elencamos em nossas operações e modos de espacialização e nem mesmo a desvincular da relação com outras mídias. Queremos que esse estudo possa se materializar como uma possível problematização da questão convergência/especificidade no vídeo. Quando falamos da recorrência de certas características e elementos, é importante enfatizar que elas estão atreladas às obras pertencentes aos acervos que dedicamos nosso estudo e que, se por um lado podem também ser identificadas para além dessas coleções, por outro, acaba por se restringir a apenas algumas abordagens espaciais, que acreditamos poderem ser ampliadas dentro dos próprios modos de espacialização que 
elencamos, bem como na identificação de outras relações entre vídeo e espaço que não apareceram a nós quando do contato com essas obras. Esse contato nos fez perceber também como, apesar de termos delimitado nosso recorte histórico a partir da década de 1990, a grande maioria dos trabalhos que pareceram melhor abarcar os nossos questionamentos foram produzidos a partir dos anos 2000. Isso reforça ainda mais aquela característica de uma certa retroalimentação histórica da videoarte não apenas em sua própria linguagem, mas no diálogo com outras, como levantado em nosso segundo capítulo, característica essa que apontamos como não exclusiva da videoarte, mas, de um campo de atuação humana bem mais amplo, pontuado por Rosalind Krauss, em nosso primeiro capítulo, como uma condição pós-moderna.

É importante apontar nessa relação entre vídeo e o espaço o fato de que essas práticas de espacialização de fato podem coexistir em uma mesma obra, como já apontado em alguns trabalhos durante o texto, uma espécie de acoplamento de um no outro que pode fundar uma outra complexidade de espacializações. Caixa de Pandora (2006) e Cidades Vulneráveis (2008) retomam algumas relações que fizemos com o cinema estrutural no segundo capítulo, Performações urbanas (2009) retoma na instalação o jogo de janelas do modo de espacialização que chamamos vídeo-cenário, Stephen Hurrel resgata as questões do digital que discutimos no trabalho de Lali Krotoszynski, apenas para citar alguns exemplos. Essas divisões que estabelecemos entre os modos de espacialização são dialógicas, em uma espécie de retroalimentação como bem apontou Timothy Barker (2012). Nosso esforço foi muito mais o de indicar as espacializações que mais se destacam em cada trabalho e que nos fez inclúi-lo em determinado modo de espacialização, mas com consciência dessas coexistências. Outro exemplo de ampliação pode se dar na vídeo-dilatação a partir de obras que, já apontadas por Milton Sogabe (2008), integram uma modificação da narrativa videográfica em tempo real por sensores e biosensores que são ativados pela presença do púbico no espaço. Ainda se pensarmos que propostas mono-canal, como as citadas no vídeo-espaço, podem também ser exibidas em grandes projeções veremos esses trabalhos se transmutarem naquela situação-cinema que apontamos, o que reforça a importância de considerar o contexto de apresentação dessas obras.

Indicamos ainda para esse trabalho quatro questões principais que devem ser aprofundadas para uma compreensão mais ampliada dessas relações vídeo e espaço em pesquisas futuras. A primeira se refere a apreensão do som como elemento de espacialização, considerando a natureza indissociável entre imagem e som nessa mídia vídeo. Apesar de termos apontado como esse som se espacializa na mesma medida que a imagem em alguns trabalhos, como os de Rafael França e Stephen Hurrel, temos consciência de que uma série de outras camadas referentes à espacialização podem surgir se considerarmos mais de perto esse elemento 
e suas características, que tem também um denso campo de estudo teórico. Outra questão é a presença daquilo que chamamos extensão (as fotografias e objetos por exemplo) nesses espaços. O que queremos levantar aqui é que colocamos o vídeo como um elemento de referência principal nesses espaços, e a questão que surge é onde reside então a autonomia desses outros objetos. Assim como buscamos uma certa autonomia do vídeo em relação à televisão, o cinema e ao computador, preocupa-nos a indicação nessas últimas considerações da necessidade de pensar como essas extensões podem se configurar também em sua autonomia como linguagem artística, sempre naquele par convergência/especificidade de que falamos, de maneira mais dialógica.

Outra situação está na consideração da temporalidade na constituição do espaço. Embora essa questão tenha atravessado a nossa pesquisa a partir dos estudos de Henri Bergson (2010), Merleau Ponty (2014 e 2011) e algumas breves considerações sobre o campo do digital, temos a certeza que o aprofundamento dos estudos sobre essa natureza temporal do espaço a partir de outros autores será necessário para melhor compreensão dessas espacializações que identificamos. Um caminho possível é a filosofia do tempo de Alfred Whitehead, que é aliás a base para as discussões temporais no digital levantadas por Timothy Barker (2012). Outra perspectiva que pode fundar ou mesmo modificar essas espacializações de que falamos é a saída do vídeo das galerias para a cidade, constituindo-se como intervenção urbana, onde a questão da dispersão é uma característica existente a partir de uma outra natureza de complexidade, diferente da galeria.

Esperamos a partir da relação entre os acervos estudados ter demonstrado como essas espacializações que levantamos como hipótese podem sim se referir a um contexto que se desliga de questões apenas locais. Para finalizar, reforçamos que essas operações e modos de espacialização não são, portanto, situações inabaláveis, não tivemos aqui o objetivo de estabelecer regras sobre essas questões, já que ainda podem se apresentar por outras dimensões poéticas que acabamos de apontar anteriormente e que não abarcamos nesse estudo específico. Desse modo, queremos com esse trabalho contribuir para o pensamento sobre a videoarte e seu estado contemporâneo na sua relação com outras mídias e pensando a espacialização como uma característica fundante dessas propostas. 


\section{REFERÊNCIAS BIBLIOGRÁFICAS}

ALMAS, Almir. Televisão digital terrestre: sistemas, padrões e modelos. São Paulo: Alameda, 2013.

AUMONT, Jacques. O olho interminável. São Paulo, Cosac \& Naify, 2005

AUMONT, Jacques. A imagem. Campinas, SP: Papirus, 1993.

BALSOM, Erika. Exhibiting cinema in contemporary art. Amsterdam: Amsterdam University Press, 2013.

BARBERY, Melissa. Vídeo aderências: território intervalar de reflexão e experimentação. 2012. 85 f. Dissertação (Mestrado em Artes) - Universidade Federal do Pará, Belém, 2012.

BARKER, Timothy. Time and the Digital: connecting technology, aesthetics and a process philosophy of Time. Lebanon: Dartmouth College Press, 2012.

BELLOUR, Raymond. Entre-imagens: Foto, cinema, vídeo. Campinas. SP: Papirus, 1997.

BENJAMIN, Walter. O artista como produtor. Em: BENJAMIN, Walter. Obras escolhidas Volume I. 8 ed. São Paulo: Brasiliense, 2012.

BERGSON, Henri. Matéria e Memória: ensaio sobre a relação do corpo com o espírito. 4. ed. São Paulo: Editora WMF Martins Fontes, 2010.

BISHOP, Claire. Installation art a critical history. New York: Routledge, 2005.

BOURRIAUD, Nicolas. Estética Relacional. São Paulo: Martins, 2009.

BURCH, Nöel. Práxis do cinema. São Paulo: Perspectiva, 2011.

CUBITT, Sean. Videography: video media as art and culture. London: Macmillan Education LTD, 1993.

DELEUZE, Gilles. Bergsonismo. São Paulo: Editora 34, 2012.

DUBOIS, Philippe. Cinema, vídeo, Godard. São Paulo: Cosac Naify, 2004.

DUGUET, Anne-Marie. Dispositivos. Em: MACIEL, Kátia. Transcinemas. Rio de Janeiro: Contra Capa Livraria, 2006.

ERNST, Wolfgang. Is there a specific videocity. Internationales Bochumer Videofestival 12. Berlin: Programmheft, Bochum Filmburonw, 2002. Disponível em:

https://www.medienwissenschaft.huberlin.de. Acesso em: 27 de outubro de 2015.

FLUSSER, Vilém. Filosofia da caixa preta: ensaios para uma futura filosofia da fotografia . Rio de Janeiro: Sinergia Relume Dumará, 2009. 
FOUCAULT, Michel. A ordem do discurso: aula inaugural no Collége de France, pronunciada em 2 de dezembro de 1970. 14 ed. São Paulo: Edições Loyola, 2006.

FRIED, Michael. Arte e objetividade. Revista Arte \& Ensaios, Rio de Janeiro, ano IX, n. 09, p. 130-147, jul. 2002.

GIANNETTI, Cláudia. Estética Digital: sintopia da arte, a ciência e a tecnologia. Belo Horizonte: C/Arte, 2006.

GIL, Antonio Carlos. Como Elaborar Projetos de Pesquisa. 4 ed. São Paulo: Atlas,2009.

GREGOLIN, Maria do Rosário. Foucault e Pêcheux na análise do discurso: diálogos \& duelos. São Paulo: Editora Claraluz, 2006.

HANSEN, Mark B. N. New Philosophy for new media. Estados Unidos: MIT Press, 2006.

JEFFREY, Moyra (org.). GENERATION: 25 years of contemporary art in Scotland - Reader. Scotland: The Nationl Galleries of Scotland and Glasgow Life, 2014.

KOTZ, Liz. Videoprojeção: o espaço entre telas. Em: In: MACIEL, Kátia (org.). Cinema sim: narrativas e projeções: ensaios e reflexões. São Paulo: Itaú Cultural, 2008.

KRAUSS, Rosalind. Vídeo: a estética do narcisismo. Revista Arte \& Ensaios, Rio de Janeiro, ano XV, n. 16, p. 144-157, jul. 2008.

KRAUSS, Rosalind. A escultura no campo ampliado. Revista Arte \& Ensaios, Rio de Janeiro, ano XV, n. 17, p. 128-137, jul. 2008.

LAKATOS, Eva Maria; MARCONI, Marina de Andrade. Fundamentos de Metodologia Científica. 7. ed. São Paulo: Atlhas, 2010.

MACHADO, Arlindo. Arte e mídia. Rio de Janeiro: Jorge Zahar Editora, 2007.

MACHADO, Arlindo (org.). Made in Brasil: três décadas do vídeo brasileiro. Sáo Paulo: Iluminuras: Itaú Cultural, 2007.

MACHADO, Arlindo. Pré-cinemas \& pós-cinemas. Campinas, SP: Papirus, 1997.

MACHADO, Arlindo. A arte do vídeo. São Paulo: Editora Brasiliense, 1988.

MANOVICH, Lev. The language of new media. Cambridge: MIT Press, 2001.

MEIGH-ANDREWS, Chris. A history of video art. $2^{\text {Nd }}$ edition. New York, London: Bloomsbury Academic, 2014.

MELLO, Christine. Extremidades do vídeo. São Paulo: Editora Senac São Paulo, 2008

MERLEAU-PONTY. O visível e o invisível. São Paulo: Perspectiva, 2014.

MERLEAU-PONTY, Maurice. Fenomenologia da percepção. 4 ed. São Paulo: Editora 
WMF Martins Fontes, 2011.

MORAN, Patrícia. A montagem dos VJs: entre a estimulação ótica e a física. in: Intermídias.com. Belo Horizonte, UFMG, 2004.

MORRIS, Robert. Notes on sculpture. 1966. Disponível em: www.arts.berkeley.edu/wpcontent/uploads/2016/01/robert-morris-notes.pdf. Acesso em: 05 de abril de 2016.

O'DOHERTY, Brian. No interior do cubo branco: a ideologia do espaço da Arte. São Paulo: Martins Fontes, 2007.

PARENTE, André. Cinema em contracampo. In: MACIEL, Kátia (org.). Cinema sim: narrativas e projeções: ensaios e reflexões. São Paulo: Itaú Cultural, 2008.

PARENTE, André. A forma cinema: variações e rupturas. In: MACIEL, Kátia.

Transcinemas. Rio de Janeiro: Contra Capa Livraria, 2006.

PAUL, Christine. Digital Art. London: Thames \& Hudson, 2015.

PAYNE, Simon. Image Threshold - The films and Videos of Malcolm Le Grice. Sight and Sound: Londres, 2016 (submetido). Disponível em: www.arro.anglia.ac.uk/700150/. Acesso em: 18 de dezembro de 2015.

RAMME, Noeli. Arte e construção de mundos: um estudo sobre a teoria dos símbolos de Nelson Goodman. Tese de Doutorado do Programa de Pós-Graduação em Filosofia. Pontifícia Universidade Católica do Rio de Janeiro (PUC-RIO), 2004.

REES, A.L. A history of experimental film and video. Londres: Palgrave Macmillan, 2011.

RUSH, Michael. Video Art. 2 ed. Londres: Thames \& Hudson Ltd., 2014.

RUSH, Michael. Novas Mídias na arte contemporânea. São Paulo: Martins Fontes, 2006.

SOGABE, Milton. O espaço das instalações: objeto, imagem e público. In: $\mathbf{1 7}^{\mathbf{0}}$ Encontro Nacional da Associação Nacional de Pesquisadores em Artes Plásticas: panorama da pesquisa em artes visuais. 2008. Florianópolis. Anais. Florianópolis: Associação Nacional de Pesquisadores em Artes Plásticas, 2008.

TUAN, Yi-Fu. Space and place: the perspective of experience. 8 ed. Londres: The University of Minessota Press, 2001.

TRODD, Tamara. Introduction; theorising the projected image. In: TRODD, Tamara (org.). Screen/Space: The projected image in contemporary art. (Rethinking Art's Histories Series). Manchester: Manchester University Press, 2011, 214 pp. 2011.

WERTHEIN, Margaret. Uma história do espaço de Dante à Internet. Rio de Janeiro: Jorge Zahar Ed., 2001.

WIVER, John. TV against TV: video art on television. In: COMER, Stuart. Film and video art. Londres: Tate publishing, 2009. 


\section{REFERÊNCIAS AUDIOVISUAIS}

AHORA. Direção: Melissa Barbery, 2007. Arquivo digital AVI (5 min.), color. Cópia do projeto de pesquisa Acervo de videoarte paraense: sistematização e análise crítica (CNPq/SEC/Minc).

ALEGORIA. Direção: Joeser Alvarez, 2012. Arquivo digital (3 min. 33 Seg.), color. Cópia da Videoteca do acervo da Associação Cultural Videobrasil.

ALI é um lugar que não conheço. Direção: Lucas Bambozzi, 1996. Arquivo digital (5 min. 38 seg.), color. Cópia da Videoteca do acervo da Associação Cultural Videobrasil.

A MULHER e seu marido bife - Live Images. Direção: Luiz Duva, 2001. Arquivo digital (16 min. 43 seg.), color. Cópia da Videoteca do acervo da Associação Cultural Videobrasil.

BENEATH and beyond - Art installation by Stephen Hurrel. Direção: Stephen Hurrel, 2008. Video online (9 min. e 41 seg.). Disponível em:

https://www.youtube.com/watch?v=fdxuT01WtEA

BARRUECO. Direção: Ayrson Heráclito e Danillo Barata, 2004. Arquivo digital (4 min. 34 seg.), color. Cópia da Videoteca do acervo da Associação Cultural Videobrasil.

BURUBURU. Direçâo: Ayrson Heráclito, (2011). Arquivo Digital (2 min. e 27 seg.), color. Cópia do acervo da Associação Cultural Videobrasil.

BERLIN Horse. Direção: Malcolm Le Grice, 1970. Video online, color (6 min. 38 seg.). Disponível em: www.lux.org.uk/collection/works/berlin-horse. Acesso em: 12 de junho de 2016.

BODYWEAVE. Direção: Lali Krotoszynski, 2005. CD-ROM, color. Cópia da Videoteca do acervo da Associação Cultural Videobrasil.

BURUBURU. Direção: Ayrson Heráclito, 2010. Arquivo digital (2 min. 27 seg.), color. Cópia da Videoteca do acervo da Associação Cultural Videobrasil.

CAIXA de Pandora. Direção: Orlando Maneschy, 2006. Arquivo digital AVI (3 min 23 seg.), color. Cópia do projeto de pesquisa Acervo de videoarte paraense: sistematização e análise crítica (CNPq/SEC/Minc).

CIDADES Vulneráveis. Direção: Carla Evanovitch, 2008. Arquivo digital AVI (34 min. 10 seg.), color. Cópia do projeto de pesquisa Acervo de videoarte paraense: sistematização e análise crítica $(\mathrm{CNPq} / \mathrm{SEC} / \mathrm{Minc})$.

CITY Tour. Direção: Dirceu Maués, 2008. Arquivo digital MPEG (2 min. 56 seg.), color. Cópia do projeto de pesquisa Acervo de videoarte paraense: sistematização e análise crítica (CNPq/SEC/Minc).

CLYDE Reflections. Direção: Stephen Hurrel, 2015. Arquivo digital (33 min. e 11 seg.), color. Cópia do acervo do artista 
CORPO 4K. Direção: Almir Almas, 2014. Performance Audiovisual Ao vivo (20 min.). Acervo pessoal do artista.

EKO Kanhy. Direção: Luciana Magno, 2012. Arquivo digital VOB (1 min.), color. Cópia do projeto de pesquisa Acervo de videoarte paraense: sistematização e análise crítica (CNPq/SEC/Minc).

ESTUDO sobre a escuridão. Direção: Márcia Vaitsman, 2009. Arquivo digital (14 min.), color. Cópia da Videoteca do acervo da Associação Cultural Videobrasil.

FAST / Slow_Scapes. Direção: Gisele Beiguelman, 2006. Arquivo digital (19 min. 35 seg.), color e p\&b. Cópia da Videoteca do acervo da Associação Cultural Videobrasil.

GETTING Out. Direção: Rafael França, 1984. Arquivo digital (5 min.), color. Cópia da Videoteca do acervo da Associação Cultural Videobrasil.

MANGUEIRAS de Belém. Direção: Valzeli Sampaio, 2011. Arquivo digital AVI (1 min. 31 seg.0, color. Cópia do projeto de pesquisa Acervo de videoarte paraense: sistematização e análise crítica (CNPq/SEC/Minc).

O JOGO ou para que servem os amigos? Direção: Valzeli Sampaio, 2006. Arquivo digital MPEG (11 seg.), color. Cópia do projeto de pesquisa Acervo de videoarte paraense: sistematização e análise crítica (CNPq/SEC/Minc).

OMOLU não é São Lázaro. Direção: Flávio Lopes, 2003. Arquivo digital (2 min. $31 \mathrm{seg}$.), color. Cópia da Videoteca do acervo da Associação Cultural Videobrasil.

O SENHOR é meu pastor e nada me faltará. Direção: Victor De La Rocque, 2012. Arquivo digital AVI (9 min. $50 \mathrm{seg}$ ), color. Cópia do projeto de pesquisa Acervo de videoarte paraense: sistematização e análise crítica (CNPq/SEC/Minc).

PANDORA The electronic box. Direção: Mariano Klautau Filho, 1995. Arquivo digital VOB ( 8 min. e 09 seg.), color e p\&b. Cópia do projeto de pesquisa Acervo de videoarte paraense: sistematização e análise crítica (CNPq/SEC/Minc).

PANDORA The eletronic box. Mariano Klautau Filho, 1993. Arquivo digital VOB (3 min. 40 seg.), color e p\&b. Cópia do projeto de pesquisa Acervo de videoarte paraense: sistematização e análise crítica (CNPq/SEC/Minc).

PERFORMAÇÕES urbanas. Direção: Carla Evanovitch, 2009. Arquivo digital AVI (5 min. 01 seg.), color. Cópia do projeto de pesquisa Acervo de videoarte paraense: sistematização e análise crítica $(\mathrm{CNPq} / \mathrm{SEC} / \mathrm{Minc})$.

PERMANÊNCIA. Direção: Valzeli Sampaio e Mariano Klautau Fiho, 2007. Arquivo digital AVI (01 min.), color. Cópia do projeto de pesquisa Acervo de videoarte paraense: sistematização e análise crítica (CNPq/SEC/Minc).

PROJECT Camelot a rothschild speaks out. Direção: Kerry Lynn Cassidy, 2013. Video online (1 hora, 8 min. e 47 seg.). Disponível em: https://www.youtube.com/watch?v=z4Vij4LsVO4 
RADICAIS Livre/os. Direção: Marcus Bastos, 2007. Arquivo digital (14 min. 20 seg.), color. Cópia da Videoteca do acervo da Associação Cultural Videobrasil.

RESSONAR, Insular. Direção: Breno Filo, 2013. Arquiv digital AVI (4 min. 22 seg.), color. Cópia do projeto de pesquisa Acervo de videoarte paraense: sistematização e análise crítica (CNPq/SEC/Minc).

SANTOSCÓPIO = Dumontagem. Direção: Carlos Adriano, 2010. Arquivo digital (16 min. 35 seg.), color e p\&b. Cópia da Videoteca do acervo da Associação Cultural Videobrasil.

SOCO na imagem. Direção: Danillo Barata, 2007. Arquivo digital (1 min. 32 seg.), color. Cópia da Videoteca do acervo da Associação Cultural Videobrasil.

THERSHOLD. Direção: Malcolm Le Grice, 1972, Video online (13 min.), color. Disponível em: www.lux.org.uk/collection/works/threshold. Acesso em: 12 de junho de 2016.

VERMELHO. Direção: Melissa Barbery, 2007. Arquivo digital AVI (1 min. 49 seg.), color. Cópia do projeto de pesquisa Acervo de videoarte paraense: sistematização e análise crítica (CNPq/SEC/Minc).

VICTROLA. Direção: Nam June Paik, 2005. p\&b. Assistido em exposição na Tate Modern, Londres. 
7. APÊNDICE 


\subsection{APÊNDICE A - Dados de obras citadas}

\section{Capítulo 02 - Vídeo}

\begin{tabular}{|l|l|}
\hline 01. Título: Alegoria & Ano: 2012 \\
\hline Duração: 3'33” & $\begin{array}{l}\text { Autor: Coletivo } \\
\text { Madeiristas }\end{array}$ \\
\hline
\end{tabular}

Sinopse: Nas visões xamânicas induzidas por peiote - substância psicotrópica - que descreve em livros como A erva do diabo, o escritor peruano Carlos Catañeda menciona a sensação de visualizar formas ovoides, que relaciona a figuras humanas em sua manifestação espiritual primordial. Os artistas usam imagens alteradas de um desfile de escola de samba para recompor essa visão, como se quisessem desconstruir uma manifestação popular diluída para fazê-la retroceder até a origem, em um imaginário mágico, primitivo. Integra o acervo da Associação Cultural Videobrasil. Foi exibido no $18^{\circ}$ Festival de Arte Contemporânea Sesc_Videobrasil (2013), em São Paulo - SP. Fonte: www.videobrasil.org.br.

\begin{tabular}{|l|l|}
\hline 02. Título: Ali é um lugar que não conheço & Ano: 1996 \\
\hline Duração: 5’38” & Autor: Lucas Bambozzi \\
\hline $\begin{array}{l}\text { Sinopse: Serie de videopoemas experimentais que fala do fascinio pelo desconhecido, pelo que ainda não se } \\
\text { possui.O desejo pelo outro lugar e os conflitos gerados na pessoa de quem se está próximo. Integra o acervo } \\
\text { da Associação Cultural Videobrasil. Foi exibido no } 12^{\circ} \text { Festival Internacional de Arte Eletrônica (1998), em } \\
\text { São Paulo - SP. Fonte: www.videobrasil.org.br }\end{array}$ \\
\hline
\end{tabular}

\begin{tabular}{|l|l|}
\hline 03. Título: Bodyweave & Ano: 2005 \\
\hline Duração: Variável & $\begin{array}{l}\text { Autor: Lali } \\
\text { Krotoszynski }\end{array}$ \\
\hline $\begin{array}{l}\text { Sinopse: Performance. A ideia de o artista ser simultaneamente o sujeito e o objeto da criação. Fusão entre } \\
\text { arte e vida no desejo de retomar o lema dadaísta. Integra o Acervo da Associação Cultural Videobrasil. Foi } \\
\text { exibido no } 15^{\circ} \text { Festival Internacional de Arte Eletrônica - Performance (2005), em São Paulo - SP. Fonte: } \\
\text { www.videobrasil.org.br. }\end{array}$ \\
\hline
\end{tabular}

\begin{tabular}{|l|l|}
\hline 04. Título: Berlin Horse & Ano: 1970 \\
\hline Duração: 6’38" & $\begin{array}{l}\text { Autor: Malcolm Le } \\
\text { Grice }\end{array}$ \\
\hline $\begin{array}{l}\text { Sinopse: "Esse filme é foi realizado como uma exploração dessa própria mídia em certos aspectos. Está } \\
\text { também preocupado com certas concepções sobre o tempo em um modo mais ilusório do que eu estava } \\
\text { inclinado a explorar em outros filmes. É uma tentativa de lidar com alguns paradoxos das relações com o } \\
\text { tempo 'real' que existe quando o filme foi gravado, com o tempo 'real' que existe quando filme é projetado e } \\
\text { como isso pode ser modulado pela manipulação técnica de imagens e sequências. O filme é uma junção de } \\
\text { duas partes por uma sobreposição central do material. A primeira parte é constituída por uma pequena seção } \\
\text { de filme capturado em 8mm colorida, e depois refilmada de várias formas para a projeção em 16mm. O } \\
\text { segundo material foi revelado em uma sobreposição de negativo e positivo a partir de filtros de cores, criando } \\
\text { uma contínua mudança de colorização na imagem, trabalhando um tempo abstrato na imagem”. Malcolm Le } \\
\text { Grice. Fonte: http://lux.org.uk/collection/works/berlin-horse. }\end{array}$ \\
\hline
\end{tabular}




\section{Título: City Tour}

Ano: 2008

Duração: 2'56

Autor: Dirceu Maués

Sinopse: Citytour01 faz um passeio às avessas pela cidade: nada de pontos turísticos, monumentos, cartões postais, mas a cidade precária, do caos e da fragmentação. Expõe a desorganização do espaço urbano e suas tensões em um turbilhão de imagens captadas, com um celular e sem cortes de edição, da janela de um carro, utilizando o acaso e acidentes de percurso como potência poética. Exibido no Salão Arte Pará (2008). Fonte: acervo do projeto de pesquisa Acervo de Videoarte paraense: sistematização e análise crítica (CNPq/SEC/MinC - 2014-2016).

\begin{tabular}{|l|l|}
\hline 06. Título: Eko Kanhy & Ano: 2012 \\
\hline Duração: 1' & Autor: Luciana Magno \\
\hline Sinopse: "Eko" do Guaraní "ser" ou "estar" que também pode significar "sistema cultural”. "Kanhy” do \\
$\begin{array}{l}\text { Guaraní "sumir", "desaparecer". Exibido na Exposição Outra Natureza: seis diálogos sobre a amazônia } \\
\text { (2012), no Espaço Cultural Banco da Amazônia. Fonte: acervo do projeto de pesquisa Acervo de Videoarte } \\
\text { paraense: sistematização e análise crítica (CNPq/SEC/MinC - 2014-2016). }\end{array}$ \\
\hline
\end{tabular}

\begin{tabular}{|l|l|}
\hline 07. Título: Estudo sobre a escuridão & Ano: 2009 \\
\hline Duração: 14' & Autor: Márcia Vaitsman \\
\hline Sinopse: Retificar o rio São Francisco como se edita um vídeo é alterar não apenas seu traçado visível, mas \\
o cotidiano de vidas que se ligam estreitamente a ele. Diante de um rio que está prestes a ter seu leito \\
transposto, a artista atenta à escuridão que o circunda ao anoitecer. No crepúsculo de um percurso físico e de \\
memórias, a obra cria intervenções na paisagem que metaforizam a mudança do rio e suas diversas fases. \\
Integra o acervo da Associação Cultural Videobrasil. Foi exibido no 17 $7^{\circ}$ Festival de Arte Contemporânea \\
Sesc_Videobrasil (2013), em São Paulo - SP. Fonte: www.videobrasil.org.br.
\end{tabular}

\begin{tabular}{|l|l|}
\hline 08. Título: Live-taped Video Corridor & Ano: 1970 \\
\hline Duração: Variável & Autor: Bruce Nauman \\
\hline $\begin{array}{l}\text { Sinopse: Instalação que dá continuidade ao Performance Corridor (1969), instituindo discussões acerca de } \\
\text { vigilância imposição de limites físicos e situações controladas. Trata-se de um corredor fito por paredes falas } \\
\text { que abrigam no final do caminho dois monitores, um exibindo uma fita pré-gravada do próprio corredor e } \\
\text { outra exibindo imagens ao vivo gravadas por uma câmera localizada na entrada. Fonte: www.guggenheim.org }\end{array}$ \\
\hline
\end{tabular}

\begin{tabular}{|l|l|}
\hline 09. Título: Nixon & Ano: 1965 - 2002 \\
\hline Duração: Loop & Autor: Nam June Paik \\
\hline $\begin{array}{l}\text { Sinopse: Essa vídeo instalação se baseia nas mais significativas imagens televisivas do Presidente Richar } \\
\text { Nixon, desde o seu discurso inaugural em } 1969 \text { até a seu discurso de renúncia após o escândalo de Watergate } \\
\text { em 1974. Bobinas magnéticas anexadas às telas causam na imagem saltos e deformações, distorcendo as } \\
\text { imagens. Subvertendo o material broadcats, Paik transforma a televisão em um meio participativo. A escolha } \\
\text { de Nixon como sujeito remete à natureza manipuladora e autoritária do controle do estado sobre as imagens } \\
\text { televisivas. A instalação foi concebida por Paik em 1965, e apresentada nesse forma em 2002 (tradução nossa). } \\
\text { Fonte: Placa de identificação da obra na exposição Nam June Paik, na Tate Modern em Londres (Inglaterra). }\end{array}$ \\
\hline
\end{tabular}


10. Título: Omolu não é São Lazaro

Duração: 2'31'

Ano: 2003

Sinopse: O sincretismo foi a principal estratégia que a cultura africana encontrou para se preservar no Brasil. O princípio de fundir elementos de origens diferentes guia esse exercício visual. A partir de estruturas simbólicas do catolicismo, a câmera cria grafismos que lembram o candomblé. Integra o acervo da Associação Cultural Videobrasil. Foi exibido no $15^{\circ}$ Festival Internacional de Arte Eletrônica - Performance (2005), em São Paulo - SP. Fonte: www.videobrasil.org.br.

\begin{tabular}{|c|c|}
\hline 11. Título: Projeto Telepatia & Ano: 2010 \\
\hline Duração: Variável & Autor: Coletivo \\
\hline \multicolumn{2}{|c|}{$\begin{array}{l}\text { Sinopse: Grupos de ativistas libertários espalhados pelo planeta começam a desenvolver capacidades } \\
\text { telepáticas. Sem dependerem de máquinas industriais e nem de energia elétrica para se comunicarem, eles } \\
\text { começam a realizar atos orquestrados de terrorismo poético com o objetivo de desestabilizar a ordem } \\
\text { hipnótica } \\
\text { Os telepatas iniciam uma outra sociedade paralela e secreta que se estende por todo o planeta: aonde isso vai } \\
\text { parar? Participam desse projeto Daniel Seda, José Luiz Sampaio, Erik Thurm, Paulito, Rogério Borovik, } \\
\text { Filipe Espíndola + Bruna Guedes. Integra o Acervo da Associação Cultural Videobrasil. Foi exibido no o 14 } \\
\text { Festival Internacional de Arte Eletrônica Videobrasil, em São Paulo - SP. Fonte: www.telepatia.blogspot.com. }\end{array}$} \\
\hline
\end{tabular}

12. Título: Soco na imagem

Ano: 2007

Duração: 1'32"

Autor: Danillo Barata

Sinopse: Performance. A ideia de o artista ser simultaneamente o sujeito e o objeto da criação. Fusão entre arte e vida no desejo de retomar o lema dadaísta. Integra o acervo da Associação Cultural Videobrasil. Foi exibido no $16^{\circ}$ Festival Internacional de Arte Eletrônica - Limite (2007), em São Paulo - SP. Fonte: www.videobrasil.org.br.

\begin{tabular}{|l|l|}
\hline 13. Título: Threshold & Ano: 1972 \\
\hline Duração: 13' & $\begin{array}{l}\text { Autor: Malcom Le } \\
\text { Grice }\end{array}$ \\
\hline
\end{tabular}

Sinopse: "O uso inicial de filtros verdes e vermelhos abre caminho para uma variedade de cores e para a introdução de tiras de celuloide que constroem uma imagem graficamente e espacialmente complexa - até mesmo abstrata - e que evoca as pinturas de artista como Clifford Still ou Morris Louis. O filme culmina em uma imagem fotográfica representacional - Deke Dusinberre. Fonte: www.lux.org. uk (LUX artists' moving image).

\begin{tabular}{|l|l|}
\hline 14. Título: Vermelho & Ano: 2007 \\
\hline Duração: 1'49 & Autor: Melissa Barbery \\
\hline $\begin{array}{l}\text { Sinopse: Um pequeno inseto se move sobre um líquido vermelho, os rastros de seu deslocamento imprimem } \\
\text { na superfície uma espécie de pintura onde o corpo deste ser é o próprio instrumento do processo pictórico. } \\
\text { Seus movimentos sugerem uma agonizante experiência. O som possui um tom agudo, seguido por uma } \\
\text { expiração profunda e um enigmático suspiro feminino. Sua repetição constante reforça ainda mais a } \\
\text { subjetivação de uma ação atormentada. Participou da exposição individual Color Bars (2007) no Espaço } \\
\text { Cultural do Banco da Amazônia em Belém do Pará. Fonte: acervo do projeto de pesquisa Acervo de Videoarte } \\
\text { paraense: sistematização e análise crítica (CNPq/SEC/MinC - 2014-2016). }\end{array}$ \\
\hline
\end{tabular}




\section{Capítulo 03 - Modos de espacialização do vídeo.}

\begin{tabular}{|l|l|}
\hline 01. Título: Ahora & Ano: 2007 \\
\hline Duração: $5^{\prime}$ & Autor: Melissa Barbery \\
\hline
\end{tabular}

Sinopse: Este vídeo trata da memória como algo vulnerável e passageiro, inicia com um texto escrito pela artista e falado pela sua avó em sua língua natal, espanhol, esta narração é seguida de uma performance onde um planta é despetalada exaustivamente. A instalação é uma Paisagem contemporânea, composta pelo vídeo e por uma planta, esta recebe um foco de luz constantemente numa tentativa de reproduzir o mesmo clima em que o vídeo foi criado, sugerindo um convite ao público para partilhar das reflexões da artista a certa das questões que envolvem a "memória" seja ela individual ou coletiva e quem sabe também despetalar a planta. Foi premiada no 26 Salão Arte Pará (2007) participou da exposição Panorama da Arte Digital no Pará. (2012), AMBAS EM Belém do Pará. Fonte: acervo do projeto de pesquisa Acervo de Videoarte paraense: sistematização e análise crítica (CNPq/SEC/MinC - 2014-2016).

02. Título: A mulher e seu marido bife - Live Images

Duração: 16 '43"
Ano: 2001

Autor: Luiz Duva

Sinopse: A relação de uma mulher com seu marido, um bife: entre pancadas, amassos e apertos, o desenrolar dessa paixão. Performance que mescla a manipulação ao vivo de imagens e sons pré-gravados e a participação, em cena, da atriz Fabiana Prado. Apresentada no $13^{\circ}$ Festival Internacional de Arte Eletrônica Videobrasil (2001). Integra o acervo da Associação Cultural Videobrasil. Foi exibido no $13^{\circ}$ Festival Internacional de Arte Eletrônica (2001), em São Paulo - SP. Fonte: www.videobrasi.org.br.

\begin{tabular}{|l|l|}
\hline 03. Título: Bakelite Robot & Ano: 2002 \\
\hline Duração: Variável & Autor: Nam June Paik \\
\hline
\end{tabular}

Sinopse: Paik foi fascinado pela figura do robô e criou seus primeiros radio-controlled robots em 1964. Esse trabalho tardio é uma figura escultural construída usando nove rádios Bakelite, que o artista adquiriu em lojas e mercados de antiguidade. Beakelite foi um antigo plástico resistente ao calor que foi comumente usado para a construção de equipamentos eletrônicos domésticos e brinquedos infantis entre os anos 1930 e 1940 . Paik costumizou os rádios par incorporar trechos de vídeos. A qualidade arcaica nos leva de volta a uma época em que as tecnologias de comunicação global estavam apenas começando a fazer parte da vida cotidiana (tradução nossa). Fonte: Placa de identificação da obra na exposição Nam June Paik, na Tate Modern em Londres (Inglaterra).

\begin{tabular}{|l|l|}
\hline 04. Título: Barrueco & Ano: 2004 \\
\hline Duração: 4'34” & $\begin{array}{l}\text { Autor: Ayrson Heráclito } \\
\text { e Danillo Barata }\end{array}$ \\
\hline
\end{tabular}

Sinopse: Dos dois lados do Atlântico, pessoas de ascendência africana idolatram a água como casa dos principais espíritos. O elo espiritual é afetado pelo comércio de escravos, que inaugura o terror do oceano imenso, simbolizando a ferida da separação para mais de 9 milhões de pessoas. Um termo espanhol que designa pérolas imperfeitas, criadas por correntes fortuitas, dá título ao trabalho. Combinado com a voz de Nina Simone e os versos do poema Divisor, de Mira Albuquerque, seu apanhado de elementos visuais simbólicos - a superfície ambarina do dendê fervendo, o navio negreiro -orquestra a dor da opressão dos corpos para sempre em trânsito. Integra o acervo da Associação Cultural Videobrasil. Foi exibido no $15^{\circ}$ Festival Internacional de Arte Eletrônica - Performance (2005), em São Paulo - SP. Fonte: www.videobrasil.org.br. 


\begin{tabular}{|l|l|}
\hline 05. Título: Beneath an beyond & Ano: 2008 \\
\hline Duração: Variável & Autor: Stephen Hurrel \\
\hline $\begin{array}{l}\text { Sinopse: Beneth and beyond é uma obra de arte impulsionada por dados de som que nos permitem } \\
\text { experienciar os constantes movimentos e modificações tectônicas que acontecem abaixo da superfície } \\
\text { terrestre em tempo real. Tem sido experienciado como um ambiente sonoro imersivo e vídeo instalação em } \\
\text { galerias e festivais na Europa, Estados Unidos, Austrália desde sua primeira apresentação na Tamway Gallery } \\
\text { em Glasgow em } 2008 \text { como parte do Festival Internacional de Artes Visuais de Glasgow. Comissionado pelo } \\
\text { Creative Scotland Award. Esta obra dá continuidade a pesquisa sobre a relação humana com o mundo natural } \\
\text { enquanto vivemos em um tempo de avançado teor tecnológico e ecologicamente crítico. Fonte: } \\
\text { www.hurrel.visualarts.com }\end{array}$ \\
\hline
\end{tabular}

\begin{tabular}{|l|l|}
\hline 06. Título: Buruburu & Ano: 2010 \\
\hline Duração: 2'27’ & Autor: Ayrson Heráclito \\
\hline $\begin{array}{l}\text { Sinopse: Buruburu designa pipoca em dialeto afro-brasileiro. Na simbologia religiosa do Candomblé, a } \\
\text { pipoca é a flor de Obaluaê, orixá das doenças e curas. A obra alude ao banho de pipoca como fonte de energia, } \\
\text { que limpa vigorosamente corpo e alma. O trabalho de Heráclito analisa questões rituais, simbólicas e } \\
\text { etnográficas, ao mesmo tempo em que discute a relação entre as construções culturais e o curso espontâneo } \\
\text { dos fenômenos. Integra o Acervo da Associação Cultural Videobrasil. Foi exibido no o } 17^{\circ} \text { Festival de Arte } \\
\text { Contemporânea Sesc_Videobrasil92011), em São Paulo - SP. Fonte: www.videobrasil.org.br }\end{array}$ \\
\hline
\end{tabular}

\begin{tabular}{|l|l|}
\hline 07. Título: Caixa de Pandora & Ano: 2006 \\
\hline Duração: 3'23" & Autor: Caixa de Pandora \\
\hline Sinopse: Video que compõe o projeto coletivo de exposição desenvolvido pelo grupo Caixa de Pandora (em \\
sua última formação com Cláudia Leão, Mariano Klautau Filho e Orlando Maneschy, já sem Flavya Mutran) \\
no Projeto Coletivos, curado por Marisa Mokarzel para o Laboratório das Artes/Casa das Onze Janelas. Este \\
video era projetado em um grande vidro empoeirado com pó dourado, localizado em um canto da galeria \\
(proposição de Cláudia Leão). As paredes traziam imagens dos três artistas colocadas ao longo do espaço. \\
Nessa instalação havia uma pequena mesa de estudos. Sobre ela um caderno de poemas de Mário Faustino, \\
cinzeiro, cigarros, canetas e um microfone ligado a um sistema de som em que o participante poderia \\
performar lendo e gravando o poema que preferisse do caderno poesias (proposição de Mariano Klautau \\
Filho). No video, uma cidade noturna e misteriosa escondida nas sobras de mangueiras e iluminação pontual \\
parece convidar a ser desvendada ou esquecida. As fronteiras das autorias se diluíram nessa última instalação \\
do Caixa de Pandora. Fonte: acervo do projeto de pesquisa Acervo de Videoarte paraense: sistematização e \\
análise crítica (CNPq/SEC/MinC - 2014-2016).
\end{tabular}

\begin{tabular}{|l|l|}
\hline 08. Título: Cidades Vulneráveis & Ano: 2008 \\
\hline Duração: 34'10" & Autor: Carla Evanovitch \\
\hline Sinopse: Cidades Vulneráveis trata-se de uma vídeoinstalação feita para ocupar uma sala, utilizando uma \\
parede em que foi colocada uma placa de rua coletada após um acidente de trânsito na Avenida Almirante \\
Barroso, uma das mais movimentadas de Belém do Pará. De maneira que ao entrar na sala, a cena vista seja \\
de um local sem iluminação, com paredes escuras, iluminadoas somente por uma projeção de vídeo, ocupando \\
uma parede inteira. O vídeo mostra o trajeto ao longo de toda a Avenida Almirante Barroso, até o conjunto \\
Júlia Seffer, localizado na BR-316, em um dos horários de maior tráfego de carros, propondo ao público um \\
"passeio" às 19:00h no sentido Belém/Ananindeua (retorno para casa), assumindo a possibilidade de \\
presenciar todos os riscos e cenas cotidianas, impostas pelo caos urbano. O vídeo de 34'10min é intercalado \\
por frases, a fim de conduzir o olhar do visitante à uma narrativa entre palavra e imagem, pela perspectiva de \\
um morador do Município de ANANINDEUA-PA, que reside no lado oposto a seu trabalho e faculdade, e \\
que se submete diariamente ao trânsito caótico, atravessando a cidade, de um extremo a outro, para exercer \\
suas atividades cotidianas em um exercício diário e sem fim. Edição: Carol Abreu. Vencedora do Prêmio de \\
Artes Visuais do Sistema Integrado de Museus e Memoriais do Pará. Participou ainda da exposição na Galeria \\
Fidanza (2009) em Belém d Pará. Fonte: acervo do projeto de pesquisa Acervo de Videoarte paraense: \\
sistematização e análise crítica (CNPq/SEC/MinC - 2014-2016).
\end{tabular}




\begin{tabular}{|l|l|}
\hline 09. Título: Corpo 4K & Ano: 2014 \\
\hline Duração: 20' & Autor: Almir Almas \\
\hline Sinopse: Performance audiovisual ao vivo que discute por meio da tecnologia 4K questões relacionadas a um \\
processo de hibridismo entre culturas, especificamente entre a cultura japonesa e a cultura afro-brasileira, por \\
meio da dança Butoh e da Capoeira. Apresentada no teatro da Faculdade de Medicina da Universidade de São \\
Paulo durante o Cine Grid 2014. Os agentes da performance audiovisual foram: diretor/VJ, Almir Almas, \\
performance audiovisual ao vivo em tempo real; equipe técnica audiovisual, assistentes de direção, produção \\
e câmeras, iluminadores e técnicos de som; músico, Roger Bacoom, trilha sonora e mixagem ao vivo; \\
performer de dança Butoh, Emilie Sugai; performer capoeirista, Fábio Rocha Soneca; performer capoeirista, \\
Mestre Griot Alcides Lima; equipe de rede, coordenada por Fernando Redigolo, do Laboratório de Arquitetura \\
e Redes de Computadores do Departamento de Engenharia de Computação e Sistemas Digitais da Escola \\
Politécnica da Universidade de São Paulo, sob direção técnica de Tereza Cristina Melo de Brito Carvalho; \\
equipe de engenharia de compressão e digitalização em 4K do LAVID (Laboratório de Aplicações de Vídeo \\
Digital), do Departamento de Informática da Universidade Federal da Paraíba, sob a direção do Prof. Dr. \\
Guido Lemos; equipe de integração técnica, comandada por Thiago Afonso de André, do PPGMPA e do \\
CINUSP, um dos Organizadores do Congresso Internacional Cinegrid Brasil 2014; o público participante \\
sentado nas cadeiras da platéia do teatro.
\end{tabular}

\begin{tabular}{|l|l|}
\hline 10. Título: Crossing Points & Ano: 2011 \\
\hline Duração: 32 '30" & Autor: Carlos Adriano \\
\hline
\end{tabular}

Sinopse: Registros em vídeo produzidos por guerrilheiros colombianos, confiscados por autoridades do país, são expostos em ambiente que sugere, ao mesmo tempo, construção e demolição. A apropriação de imagens reveladoras do poder e da violência da guerrilha, e ainda assim carregadas de aspectos prosaicos, traduz a ironia característica do artista, ao lado de uma crueza perturbadora. Integra o Acervo da Associação Cultural Videobrasil. Foi exibido no o $17^{\circ}$ Festival de arte Contemporânea Sesc_Videobrasil (2011), em São Paulo SP. Fonte: www.videobrasil.org.br

\begin{tabular}{|l|l|}
\hline 11. Título: Fast / Slow Scapes (nomadic videos) & Ano: 2006 \\
\hline Duração: 19’35” & $\begin{array}{l}\text { Autor: Gisele } \\
\text { Beiguelman }\end{array}$ \\
\hline
\end{tabular}

Sinopse: Conjunto de capítulos que formam um diário de imagens, construído pela camera do celular. Cada qual foi gravado em um lugar diferente, a partir de um diferente veículo em movimento, oferecendo diversos pontos de vista à condição nômade. Integra o acervo da Associação Cultural Videobrasil. Foi exibido no $16^{\circ}$ Festival Internacional de Arte Eletrônica - Limite (2007), em São Paulo - SP. Fonte: www.videobrasil.org.br.

\begin{tabular}{|c|c|}
\hline 12. Título: Getting Out & Ano: 1984 \\
\hline Duração: 5' & Autor: Rafael França \\
\hline \multicolumn{2}{|c|}{$\begin{array}{l}\text { Sinopse: Neste segundo experimento sobre a narrativa de video, objetos do cotidiano assumem significância } \\
\text { psicológica quando a protagonista combate a opressão de seu ambiente doméstico. O realismo aparente é uma } \\
\text { estratégia artificial para o desenvolvimento de uma trama que não traz a realidade, mas um estado de espírito. } \\
\text { Integra o acervo da Associação Cultural Videobrasil. Foi apresentado na Retrospectiva Rafael França (2001), } \\
\text { em São Paulo - SP. Fonte: www.videobrasil.org.br. }\end{array}$} \\
\hline
\end{tabular}




\begin{tabular}{|l|l|}
\hline 13. Título: Mangueiras de Belém & Ano: 2011 \\
\hline Duração: 1'31' & Autor: Valzeli Sampaio \\
\hline
\end{tabular}

Sinopse: O projeto iniciou em 2008 em Wiesbaden (Alemanha), no processo da residência artística na Kunsthaus. A relação da cidade com o verde, as arvores catalogadas, numeradas, em impecáveis parques, me afetaram ao comparar a relação que minha cidade Belém $(\mathrm{Pa})$ tem com a natureza. Marcar árvores de avenidas e ruas com números e com GPS, busca refletir o estado de invisibilidade dessas árvores na vida das pessoas, e ao mesmo tempo possibilitar (ou não) o reencontro à visibilidade. Estas intervenções buscam provocar interação com os frequentadores e visitantes. A primeira intervenção ocorreu em 2008 e segunda aconteceu em 2011 no Arte Pará. Material: imagens, mapas e vídeos. MANGUEIRAS (2008): 01 vídeo do processo de marcação das árvores; 01 video do tunel de mangueiras; 02 fotos em plano fechado de cada mangueira numerada. MANGUEIRAS (2011): 01 video performance Videoperformance de Val Sampaio com câmera: Luah Sampaio. Paisagem sonora: Leo Bitar. Edição: Val Sampaio.; 01 video da colagem do QR-Code na árvores; 01 QR-Code; 01 Blog do Projeto; Vários Mapas das mangueiras marcadas. Integra o acervo do projeto de pesquisa Acervo de Videoarte paraense: sitematização e análise crítica (CNPq/SEC/MinC - 20142016). Foi Exibido no $31^{\circ}$ Salão Arte Pará (2011) e na exposição Panorama da Arte Digital no Pará (2012), ambos em Belém do Pará. Fonte: acervo do projeto de pesquisa Acervo de Videoarte paraense: sistematização e análise crítica (CNPq/SEC/MinC - 2014-2016).

\begin{tabular}{|l|l|}
\hline 14. Título: O JOGO ou para que serve os amigos? & Ano: 2006 \\
\hline Duração: 11" & Autor: Valzeli Sampaio \\
\hline Sinopse: Este trabalho é um exercício em torno do tempo, o tempo das coisas, o tempo o senhor do destino, \\
o tempo como um deus que é implacável e inexorável, que governa o tempo e espaço, que acompanha e \\
cobra o cumprimento das decisões, determinando o início e o sem fim de tudo. Só o tempo nos dá a dimensão \\
das coisas, a compreensão da paciência, do aprendizado constante e sem fim, do aprimoramento. E, é no \\
tempo que determina o despertar do amor, que ensina a persistência, o aprendizado enfim, a compreensão \\
sobre aquilo que tem que passar. O tempo também é matéria de modelagem em todas as áreas de conhecimento \\
e também em todas as linguagens. O processo criativo, o ato de criar é um trabalho com o tempo. Este \\
trabalho contém três placas de vidro aplicadas com adesivo transparente e um vídeo de celular em loop. As \\
peças pretendem evocar a relação de duração, espaço e silêncios, algumas formas de expressar o tempo. \\
Participou do XV Salão Primeiros Passos do Centro Cultural Brasil Estados Unidos (2006) e da exposição \\
Amazônia, Lugar de experiência (2014), ambas em Belém do Pará. Fonte: acervo do projeto de pesquisa \\
Acervo de Videoarte paraense: sistematização e análise crítica (CNPq/SEC/MinC - 2014-2016).
\end{tabular}

\begin{tabular}{|l|l|}
\hline 15. Título: O senhor é meu pastor e nada me faltará & Ano: 2012 \\
\hline Duração: 9'50" & $\begin{array}{l}\text { Autor: Victor DeLa } \\
\text { Rocque }\end{array}$ \\
\hline $\begin{array}{l}\text { Sinopse: Não sou aquele senhor que é Pastor que promete verdes prados onde se faz repousar, sou o outro, } \\
\text { aquele que segue pelos caminhos da livre arbitrariedade, suo pelas torpes atitudes contra si, e por isso me } \\
\text { apresento como o próprio boi de um rebanho guiado num tempo que não existe, onde cada dia é o mesmo e } \\
\text { repete-se de maneira angustiante, apenas vivendo a esperar como um boi que espera a sua morte no } \\
\text { matadouro. E tudo que entra ainda fica ruminando, e o resto é apenas resto, e vira bosta. Participou do Salão } \\
\text { Arte Pará (2012) em Belém do Pará. Fonte: acervo do projeto de pesquisa Acervo de Videoarte paraense: } \\
\text { sistematização e análise crítica (CNPq/SEC/MinC - 2014-2016). }\end{array}$ \\
\hline
\end{tabular}




\begin{tabular}{|l|l|}
\hline 16. Título: Pandora the electronic box & Ano: 1995 \\
\hline Duração: 8'09' $^{\prime}$ & $\begin{array}{l}\text { Autor: Mariano Klautau } \\
\text { Fiho }\end{array}$ \\
\hline
\end{tabular}

Sinopse: Video que faz parte da videoinstalação apresentada por Mariano Klautau Filho dentro do projeto coletivo de exposição desenvolvido pelo grupo Caixa de Pandora (Cláudia Leão, Flavya Mutran, Mariano Klautau Filho e Orlando Maneschy). Na segunda mostra Caixa de Pandora cada artista aponta para sua leitura do mito de Pandora para o desenvolvimento de sua proposição. Na videoinstalação - composta por uma televisão e video-cassete dentro de uma caixa de madeira, e à sua frente fotografias do autor. Dessa vez a televisão está no chão como que jogada numa caixa de mudança. Não há mais controle remoto. As fotografias, espalhadas pelo chão, também como num ambiente em mudança, feito fotografias descartadas (cópias fotográficas imperfeitas) mostram fragmentos de edificações antigas da cidade. No vídeo, a cidade contemporânea e suas figuras femininas em vertigem contrastam com as fotografias no chão de uma cidade esquecida. São inseridos na nova edição do vídeo - as letras são escritas aos poucos tomando toda a tela em fundo preto - trechos do poema O Homem e Sua Hora, de Mário Faustino, elemento a ampliar a dimensão trágica de uma cidade devastada em sua memória. Participou da exposição Caixa de Pandora (1993) na Galeria Theodoro Braga em Belém do Pará. Fonte: acervo do projeto de pesquisa Acervo de Videoarte paraense: sistematização e análise crítica (CNPq/SEC/MinC - 2014-2016).

\begin{tabular}{|l|l|}
\hline 17. Título: Pandora the eletronic box & Ano: 1993 \\
\hline Duração: 3'40" & $\begin{array}{l}\text { Autor: Mariano Klautau } \\
\text { Fiho }\end{array}$ \\
\hline
\end{tabular}

Sinopse: Na primeira mostra Caixa de Pandora cada artista partiu do mito de Pandora para o desenvolvimento de sua proposição para integrar a mostra. Na videoinstalação - composta por uma televisão sobre um rack, um vídeo-cassete, um banco, o controle do vídeo, um par de tênis e algumas fotografias de sua autoria -, o artista disponibiliza ao público o controle do aparelho, suscitando ao mesmo uma interação com a imagem. No vídeo, aparecem em sequência as mesmas fotografias que estão em papel e disponibilizadas no espaço. $\mathrm{Na}$ tela as fotografias são editadas, ganhando movimento a partir dos cortes enquadrados pela câmera, conectadas, em alguns momentos por cenas filmadas da cidade. As figuras femininas que aparecem nas imagens são referência ao mito proposto pelo grupo e estão sempre em movimento, dentro de compartimentos fechados e tendo ao fundo imagens de uma cidade em vertigem. O ambiente da instalação permite ao público participar de um trabalho em processo no qual a metáfora da caixa eletrônica seria um espaço de experimentação da fotografia fixa. É o vídeo como elemento de ressignificação da imagem fotográfica, conferindo ritmo e movimento a esta pelas sequências e cortes. Participou da exposição Caixa de Pandora (1993) na Galeria Theodoro Braga em Belém do Pará. Fonte: acervo do projeto de pesquisa Acervo de Videoarte paraense: sistematização e análise crítica (CNPq/SEC/MinC - 2014-2016).

\begin{tabular}{|l|l|}
\hline 18. Título: Patterns & Ano: 2015 \\
\hline Duração: Variada & Autor: Bonnie Camplin \\
\hline
\end{tabular}

Sinopse: Uma sala constituída por cinco monitores, uma série de livros apresenta conteúdos que questionam nossa atuação no mundo entre a loucura e a sanidade, apresentando casos de pessoas que contam histórias sobrenaturais e o arsenal político-militar existente para tentar encobrir essas narrativas desviantes de uma normalidade social. 


\begin{tabular}{|l|l|}
\hline 19. Título: Performações Urbanas & Ano: 2009 \\
\hline Duração: 5'01" & Autor: Carla Evanovitch \\
\hline Sinopse: Cidades Vulneráveis trata-se de uma vídeoinstalação feita para ocupar uma sala, utilizando uma \\
parede em que foi colocada uma placa de rua coletada após um acidente de trânsito na Avenida Almirante \\
Barroso, uma das mais movimentadas de Belém do Pará. De maneira que ao entrar na sala, a cena vista seja \\
de um local sem iluminação, com paredes escuras, iluminadoas somente por uma projeção de vídeo, ocupando \\
uma parede inteira. O vídeo mostra o trajeto ao longo de toda a Avenida Almirante Barroso, até o conjunto \\
Júlia Seffer, localizado na BR-316, em um dos horários de maior tráfego de carros, propondo ao público um \\
"passeio" às 19:00h no sentido Belém/Ananindeua (retorno para casa), assumindo a possibilidade de \\
presenciar todos os riscos e cenas cotidianas, impostas pelo caos urbano. O vídeo de 34'10min é intercalado \\
por frases, a fim de conduzir o olhar do visitante à uma narrativa entre palavra e imagem, pela perspectiva de \\
um morador do Município de ANANINDEUA-PA, que reside no lado oposto a seu trabalho e faculdade, e \\
que se submete diariamente ao trânsito caótico, atravessando a cidade, de um extremo a outro, para exercer \\
suas atividades cotidianas em um exercício diário e sem fim. Edição: Carol Abreu. Resultado da Bolsa de \\
Pesquisa em Criação Artística do instituto de Artes do Pará (2009). Foi mapeada no programa Rumos Itaú \\
Cultural, realizando exposições em Belém, São Paulo, Rio de Janeiro e Joinville. Fonte: acervo do projeto de \\
pesquisa Acervo de Videoarte paraense: sistematização e análise crítica (CNPq/SEC/MinC - 2014-2016). \\
\hline
\end{tabular}

\begin{tabular}{|l|l|}
\hline 20. Título: Permanência & Ano: 2007 \\
\hline Duração: Loop & $\begin{array}{l}\text { Autor: Valzeli Sampaio } \\
\text { e Mariano Klautau Filho }\end{array}$ \\
\hline
\end{tabular}

Sinopse: Este trabalho é um exercício em torno do tempo, tempo das coisas, e busca articular conceitos de tempo e a percepção e a compreensão de sua presença. Esta obra é apresentada em espaço fechado sem iluminação geral com metragem $7 \mathrm{mts} x 9 \mathrm{mts}$ com pé direito de $6 \mathrm{mts}$, com projeção nas duas paredes laterais de dois vídeos com imagens de um balanço em movimento. Os projetores devem estar desalinhados para permitir a projeção da sombra de quem está no balanço em cada uma das paredes laterais. Cada um dos vídeos tem ritmos diferentes e são projetados simultaneamente. No meio da sala entre os dois vídeos é instalado o balanço representado nos vídeos, necessariamente com estrutura que permita o público sentar e balançar-se interagindo com a instalação usando o balanço. O balanço será iluminado nas extremidades em uma das paredes restantes, de maneira a projetar sombra na parede em frente ao foco redondo de um pequeno canhão de luz, criando uma imagem com a sombra daquele que está no balanço. Esta imagem/sombra se modifica na medida do envolvimento e resposta do público. O ambiente tem ruídos de ondas, pássaros, vento captados do lugar representado na instalação. Instalação de autoria de Val Sampaio e Mariano Klautau Filho - Grande Prêmio do Salão Arte Pará - 2007, em Belém do Pará. Fonte: acervo do projeto de pesquisa Acervo de Videoarte paraense: sistematização e análise crítica (CNPq/SEC/MinC - 2014-2016).

\begin{tabular}{|l|l|}
\hline 21. Título: Radicais Livre/os & Ano: 2007 \\
\hline Duração: 14 ’20” & Autor: Marcus Bastos \\
\hline
\end{tabular}

Sinopse: Debate sobre a liberdaade na sociedade contemporânea por meio de entrevistas, ensaios em vídeo e memórias sobre a história recente do Brasil. Estruturado de maneira fragmentada, o video pesquisa formatos de documentário na cultura digital. Integra o acervo da Associação Cultural Videobrasil. Foi exibido no $16^{\circ}$ Festival Internacional de Arte Eletrônica - Limite (2007), em São Paulo - SP. Fonte: www.videobrasil.org.br.

\begin{tabular}{|l|l|}
\hline 22. Título: Ressonar Insular & Ano: 2013 \\
\hline Duração: 4'22” & Autor: Breno Filo \\
\hline Sinopse: Em resposta aos constantes tsunamis cotidianos, crio um mapa composto por fragmentos de \\
mutualismo e afetividade com o espaço [...]Recortes de trilhas e fronteiras por pessoas, objetos, materiais, \\
personagens e luminosidades encontrados, coletados e destacados dos continentes da memória cotidiana. \\
Redesenhados de modo a se tornarem um paraíso necessário. Fuga banhada em águas, que ressoam em \\
saudades. E assim compartilhados. Ilha Laboratório. Para insular e experimentar. Buscar algum equilíbrio. \\
Premiado no 5 Salão SESC Universitário de Arte Contemporânea. Fonte: acervo do projeto de pesquisa \\
Acervo de Videoarte paraense: sistematização e análise crítica (CNPq/SEC/MinC - 2014-2016).
\end{tabular}




\begin{tabular}{|l|l|}
\hline 23. Título: Santoscópio = Dumontagem & Ano: 2011 \\
\hline Duração: 16 '35" & Autor: Carlos Adriano \\
\hline
\end{tabular}

Sinopse: A obra se apropria de imagens de mutoscópio, aparato que usa cartões impressos para produzir animações, numa das primeiras modalidades conhecidas de cinema. O material-base é o filme mutoscópico Santos Dumont Explaining His Airship to the Hon. C.S. Rolls, de 1901. O artista cria uma forma documental de experimentalismo, com proximidade do gênero retrato. . Integra o Acervo da Associação Cultural Videobrasil. Foi exibido no o $17^{\circ}$ Festival de Arte Contemporânea Sesc_Videobrasil (2001), em São Paulo SP. Fonte: www.videobrasil.org.br

\begin{tabular}{|l|l|}
\hline 24. Título: Victrola & Ano: 2005 \\
\hline Duração: Variável & Autor: Nam June Paik \\
\hline $\begin{array}{l}\text { Sinopse: Ess instalação escultural incorpora uma vitrola, um gramafone acoplado a um móvel, que Pik pintou } \\
\text { com grafites de simbolos. A victrola foi um produto popular nas residências americanas de 1900 a 1920. Paik } \\
\text { enfatiza sua característica antiquada, com vinis quebrados, e uma televisão de plasma na parede exibindo uma } \\
\text { de suas primeiras performances, em que quebra um vinil. Além disso, a tela também pode ser vista como um } \\
\text { equivalente conteporâneo da vitrola, afirmando o lugar das tecnologias da comunicação nas residências } \\
\text { contemporâneas. Fonte: Placa de identificação da obra na exposição Nam June Paik, na Tate Modern em } \\
\text { Londres (Inglaterra). }\end{array}$ \\
\hline
\end{tabular}

